\begin{abstract}
UNIVERSIDADE DE SÃO PAULO
ESCOLA DE ENGENHARIA DE SÃO CARLOS

PROGRAMA DE PÓS-GRADUAÇÃOEM ENGENHARIA DE PRODUÇÃO
\end{abstract}

ANTONIO IACONO

ANÁLISE DOS ELEMENTOS DETERMINANTES INTERNOS E EXTERNOS PARA

O ACÚMULO DA CAPACIDADE TECNOLÓGICA EM EMPRESAS DE BENS DE

CAPITAL NO BRASIL.

Orientador: Prof. Dr. Marcelo Seido Nagano 


\section{ANÁLISE DOS ELEMENTOS DETERMINANTES INTERNOS E EXTERNOS PARA O ACÚMULO DA CAPACIDADE TECNOLÓGICA EM EMPRESAS DE BENS DE CAPITAL NO BRASIL.}

Tese apresentada ao Programa de PósGraduação em Engenharia de Produção da Escola de Engenharia de São Carlos, da Universidade de São Paulo para obtenção do título de Doutor em Engenharia de Produção.

Área de concentração: Economia, Organizações e Gestão do Conhecimento

Orientador: Prof. Dr. Marcelo Seido Nagano 
AUTORIZO A REPRODUÇ̃̃O TOTAL OU PARCIAL DESTE TRABALHO, POR QUALQUER MEIO CONVENCIONAL OU ELETRÔNICO, PARA FINS DE ESTUDO E PESQUISA, DESDE QUE CITADA A FONTE.

Iacono, Antonio
Análise dos elementos determinantes internos e externos para o acúmulo da capacidade tecnológica em empresas de bens de capital no Brasil / Antonio Iacono; orientador Marcelo Seido Nagano. São Carlos, 2015.

Tese (Doutorado) - Programa de Pós-Graduação em Engenharia de Produção e Área de Concentração em Economia, Organizaçóes e Gestão Conhecimento -- Escola de Engenharia de São Carlos da Universidade de são Paulo, 2015.

1. Capacidade tecnológica. 2. Bens de capital. 3. Inovação. 4. Fatores internos e externos. I. Título. 
DEDICATÓRIA

Ao meu grande e infinito amor

Ana Carolina 


\section{FOLHA DE JULGAMENTO}

Candidato: Engenheiro ANTONIO IACONO.

Título da tese: "Análise dos elementos determinantes internos e externos para o acúmulo da capacidade tecnológica em empresas de bens de capital no Brasil".

Data da defesa: 13/03/2015

\section{Comissão Julgadora:}

Prof. Dr. Marcelo Seido Nagano (Orientador)

(Escola de Engenharia de São Carlos/EESC)

Prof. Associado Edmundo Escrivão Filho

(Escola de Engenharia de São Carlos/EESC)

Profa. Dra. Ana Lúcia Vitale Torkomian

(Universidade Federal de São Carlos/UFSCar)

Prof. Dr. Mário Sacomano Neto

(Universidade Federal de São Carlos/UFSCar)

Dra. Thais Elaine Vick

(Pós-Doutoranda/CNPq)
Resultado:

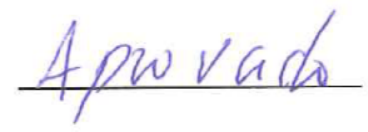

ApR $M$ ADO

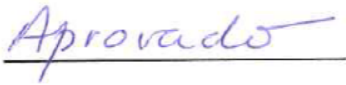

Aprovado

thaprovado

Coordenador do Programa de Pós-Graduação em Engenharia de Produção Profa. Associada Daisy Aparecida do Nascimento Rebelatto

Presidente da Comissão de Pós-Graduação:

Prof. Associado Paulo César Lima Segantine 


\section{AGRADECIMENTOS}

A Deus, pela saúde, pela força e pelos caminhos iluminados.

À minha esposa e maior amor de minha vida, Ana Carolina, que sempre me inspirou e esteve ao meu lado nesses últimos melhores 25 anos de minha vida.

Aos meus pais, pelo amor que sempre me deram, e que mesmo não mais presentes entre nós, sempre estiveram comigo.

Ao professor e amigo Nagano, com grande admiração e respeito, pela compreensão, confiança, ensinamentos, orientação e apoio nos momentos mais difíceis desse trabalho.

Aos professores Fernando Almada e Ana Lúcia Torkomian, pelas orientações e enriquecimento deste trabalho.

Ao amigo Rodrigo Amaral que muito me ajudou nesse processo. 


\section{RESUMO}

IACONO, A. Análise dos elementos determinantes internos e externos para o acúmulo da capacidade tecnológica em empresas de bens de capital no Brasil. 2015. $220 \mathrm{f}$. Tese (Doutorado) - Escola de Engenharia de São Carlos, Universidade de São Paulo, São Carlos.

O propósito desta tese é analisar e sistematizar os principais elementos determinantes internos e externos às empresas para o acúmulo de capacidade tecnológica em empresas do setor de bens de capital no Brasil. Para alcançar os objetivos propostos realizou-se um estudo descritivo-exploratório, de abordagem qualitativa, junto a 44 empresas do setor de bens de capital mecânico, localizadas na região sudeste do Brasil. A escolha desse tema justifica-se pela necessidade de um maior esforço analítico sobre o processo de acumulação de capacidade tecnológica em empresas do setor de bens de capital no Brasil. O desdobramento em elementos internos e externos possibilitou a avaliação dos esforços internos realizados pelas empresas e as limitações postas pelos condicionantes externos que atuam no processo de acúmulo de capacidade tecnológica. Os resultados mostram que em todas as dimensões analisadas as características apresentadas condicionam as empresas a uma baixa competitividade, seja por preço ou por diferenciação tecnológica. Do ponto de vista dos elementos internos é crucial que as empresas se engajem em processos contínuos de aprendizagem para a construção e acúmulo de sua capacidade tecnológica. Do ponto de vista dos elementos externos, estes exercem forte influência nos processos de acumulo de capacidade tecnológica por criarem condições desfavoráveis para investimentos, em particular, aqueles realizados com atividades com longo prazo de retorno, como as de P\&D e inovação.

Palavras-chave: capacidade tecnológica; bens de capital; inovação; fatores internos e externos 


\begin{abstract}
IACONO, A. Analysis of internal and external determinants of the accumulation of technological capacity in the capital goods companies in Brazil. 2015. $220 \mathrm{f}$. Tese (Doutorado) - Escola de Engenharia de São Carlos, Universidade de São Paulo, São Carlos.
\end{abstract}

The purpose of this thesis is to analyze and systematize the major internal and external determinants to companies for technological capability accumulation in capital goods sector companies in Brazil. To achieve the proposed objectives there was a descriptive exploratory study with a qualitative approach, along with 44 companies of the mechanical capital goods sector, located in southeastern Brazil. The choice of this theme is justified by the need for greater analytical effort on the technological capability accumulation process in capital goods sector companies in Brazil. The breakdown in internal and external elements enabled the evaluation of internal efforts of companies and the limitations posed by external constraints operating in the technological capability accumulation process. The results show that in all dimensions analyzed the characteristics presented drive companies to low competitiveness, either by price or technological differentiation. From the point of view of internal elements is crucial that companies engage in continuous learning processes for the construction and accumulation of technological capacity. From the point of view of the external elements, they exert strong influence on the accumulation processes of technological capacity for creating favorable conditions for investments, in particular those made with activities with long-term return, such as R \& D and innovation.

Keywords: technological capacity; capital goods; innovation; internal and external factors 


\section{LISTA DE FIGURAS}

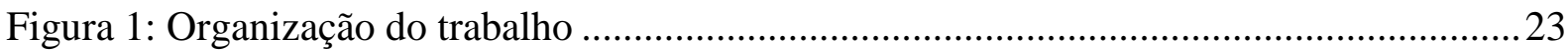

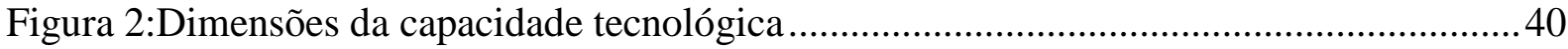

Figura 3:Acumulação tecnológica: conceitos e termos básicos ............................................. 41

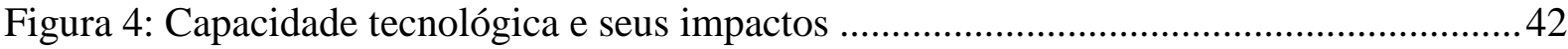

Figura 5: Trajetória de acumulação de capacidade tecnológica em empresas de países em desenvolvimento - modelo ilustrativo de catching-up............................................................51

Figura 6: Trajetória de acumulação de capacidade tecnológica em empresas de países em desenvolvimento - modelo ilustrativo frente a descontinuidades.............................................52

Figura 7: Integração das trajetórias tecnológicas de empresas de países industrializadas e em

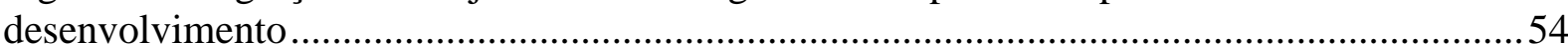

Figura 8: Trajetória de acumulação de capacidade tecnológica em empresas de países em

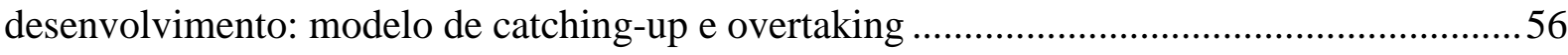

Figura 9: Fontes de aprendizado tecnológico em países de industrialização recente................58

Figura 10: Valor adicionado da manufatura mundial nas principais economias em

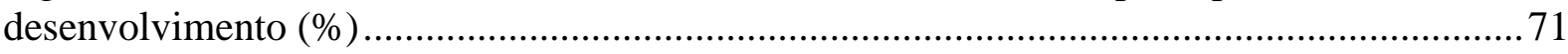

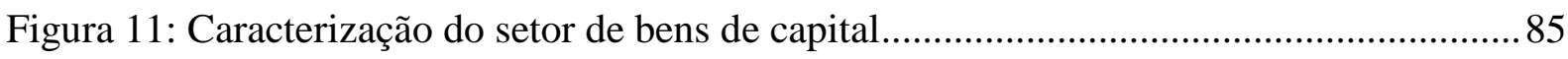

Figura 12: Cadeia produtiva de motores, bombas, compressores e equipamentos de

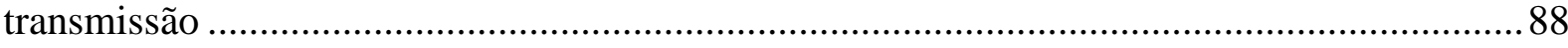

Figura 13: Cadeia produtiva de máquinas e equipamentos de uso geral............................... 88

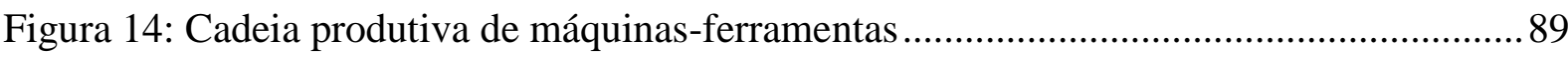

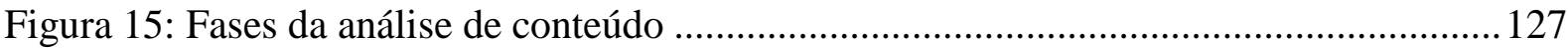




\section{LISTA DE TABELAS}

Tabela 1: Valor e participação do valor adicionado da manufatura mundial

Tabela 2: Consumo Aparente de bens de capital mecânico (US\$ bilhões constantes de 1992)

Tabela 3: Desempenho da indústria de bens de capital mecânico (US\$ milhões) 81

Tabela 4: Total de empresas e empregados no setor de bens de capital .90

Tabela 5: Número de empresas e de empregados no setor de bens de capital . .92

Tabela 6: Medidas com efeitos sobre o setor de bens de capital no Plano Brasil Maior 113

Tabela 7: Empresas selecionadas para o estudo 123

Tabela 8: Perfil das empresas . 129

Tabela 9: Características de mercado 131

Tabela 10: Destino das exportações 132

Tabela 11: Influência da China (\% do total) 133

Tabela 12: Conhecimento e monitoramento do ambiente externo 136

Tabela 13: Finalidade das atividades de inovação. 137

Tabela 14: Objetivos dos projetos de inovação em relação ao mercado 138

Tabela 15: Objetivos dos projetos de inovação em relação ao produto 139

Tabela 16: Objetivos de mercado e objetivos de produto nos projetos de inovação. 139

Tabela 17: Capital de giro como obstáculo ao crescimento das empresas..... 144

Tabela 18: Grau de concordância da obtenção de financiamento por origem da empresa .... 145

Tabela 19: Atividades no setor da qualidade 146

Tabela 20; Obstáculos para o desenvolvimento da empresa: produção com qualidade por origem da empresa.

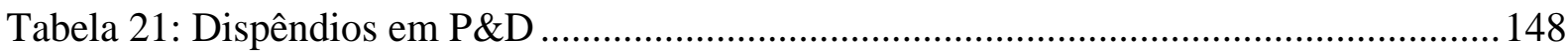

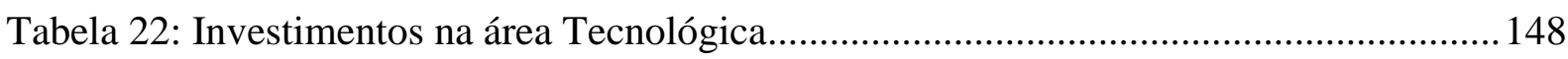

Tabela 23: Direcionamento das atividades de inovação.................................................... 149

Tabela 24: Grau de novidade atribuído ao produto ............................................................ 149

Tabela 25: Empresas seguidoras e não seguidoras por origem ........................................... 150

Tabela 26: Obstáculo para o desenvolvimento: grau de concordância da P\&D por origem da

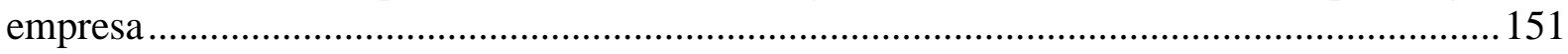

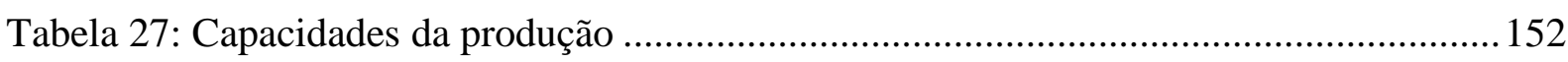

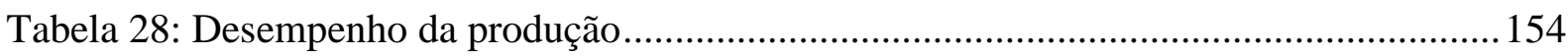

Tabela 29: Presença e intensidade dos mecanismos de aprendizagem ................................. 158

Tabela 30: Coeficiente de Alfa de Conbrach e do escore de correlação dos itens .................. 166

Tabela 31: Padrão de comportamento das empresas em relação à inovação .......................... 167

Tabela 32: Obstáculos externos ao desenvolvimento das empresas..................................... 172 



\section{LISTA DE QUADROS}

Quadro 1: Delimitação do escopo do trabalho ......................................................................2 22

Quadro 2: Matriz ilustrativa de capacidades tecnológicas .......................................................46

Quadro 3: Capacidade tecnológica industrial: um modelo ilustrativo ................................... 47

Quadro 4: Capacidades tecnológicas em empresas de economias emergentes ........................ 49

Quadro 5: Áreas de intervenção e medidas de políticas ......................................................... 61

Quadro 5: Dimensões e variáveis definidas para a pesquisa ..............................................615

Quadro 7: Inciativas e instrumentos da PDP para o setor de bens de capital........................ 109

Quadro 8: Temas da dimensão sistêmica do Plano Brasil Maior ...........................................111

Quadro 9: Objetivos e iniciativas do Plano Brasil Maior para o setor de bens de capital...... 112

Quadro 10: Prioridades estratégicas, linhas de ação e programas da PNCT\&I - Eixo I e II.. 114

Quadro 11: Modalidades e principais programas da Finep ................................................... 119

Quadro 13:Principais produtos e segmentos atendidos pelas empresas pesquisadas ............. 130 


\section{LISTA DE GRÁFICOS}

Gráfico 1: Brasil - Formação bruta de capital fixo/produto interno bruto de 2003-2011 ....... 79

Gráfico 2: Produção física de máquinas e equipamentos de 2003-2013 ................................ 80

Gráfico 3: Balança comercial brasileira de bens de capital entre 2000 e 2010 ....................... 82

Gráfico 4: Principais destinos das exportações e participação no total exportado .................... 83

Gráfico 5: Principais origens das importações e participação no total importado ................... 84

Gráfico 6: Numero de empresas nos períodos de 2000, 2006 e 2010 ....................................90

Gráfico 7: Numero de empresas nos períodos de 2000, 2006 e 2010 ......................................91

Gráfico 8: Total de recursos reembolsáveis e não reembolsáveis- Finep.............................. 118

Gráfico 9: Capacitação para produção e inovação ................................................................... 140

Gráfico 10: Necessidade de mão-de-obra qualificada no setor de engenharia de processo ... 141

Gráfico 11: Resultados pretendidos com a aquisição de novos equipamentos ...................... 143

Gráfico 12: Desempenho dos fatores de produção ................................................................. 153

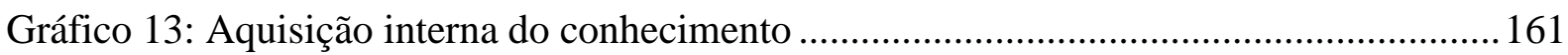

Gráfico 14: Coeficientes de variação: padrão de comportamento para a inovação................. 168

Gráfico 15: Produção da indústria de transformação, comércio varejista ampliado e paridade cambial 


\section{LISTA DE ABREVIATURAS E SIGLAS}

AF - Alto Forno

ANPEI - Associação Nacional de Pesquisa, Desenvolvimento e Engenharia das Empresas Inovadoras

CNAE - Classificação Nacional de Atividades Econômicas

CQ - Controle de Qualidade

ET - Empresa Transnacional

FBCF - Formação Bruta de Capital Fixo

IBGE -Instituto Brasileiro de Geografia e Estatística

IPEA - Instituto de Pesquisa Econômica Aplicada

ISI - Industrialização por Substituição de Importações

JIT - Just in Time

OCDE - Organização para Cooperação e Desenvolvimento Econômico

PCP - Planejamento e Controle da Produção

P\&D - Pesquisa e Desenvolvimento

Pintec - Pesquisa de Inovação Tecnológica

PITCE - Política Industrial, Tecnológica e de Comércio Exterior

SNI - Sistema Nacional de Inovação

SSI - Sistema Setorial de Inovação

TIT - Transferência Internacional de Tecnologia

TQC/M - Controle da Qualidade Total/Gestão

VCR - Vantagens Comparativas Reveladas

ZD - Zero Defeito 
1 INTRODUÇÃO

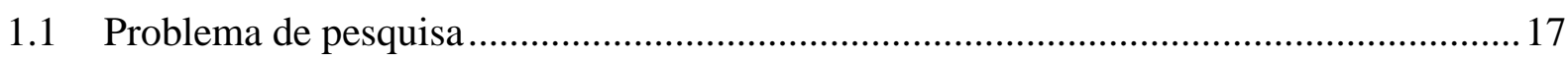

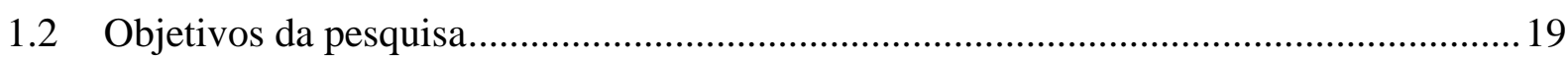

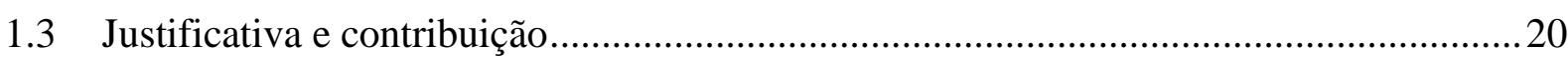

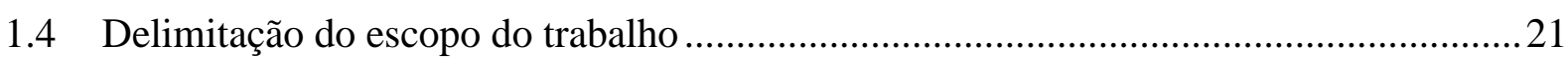

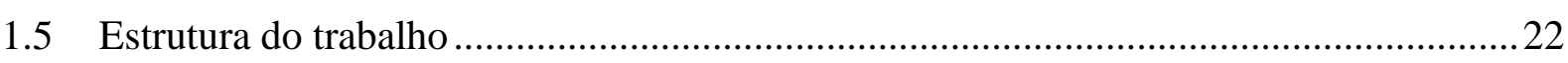

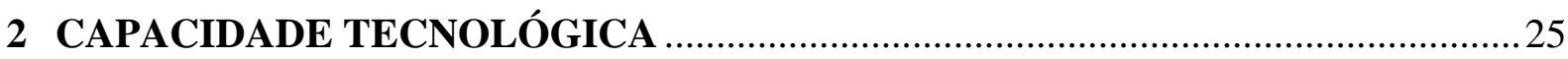

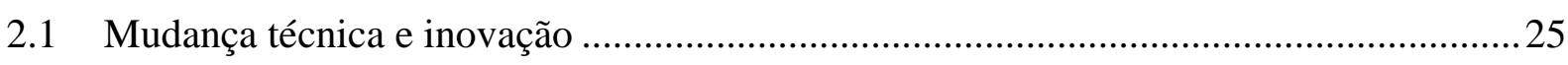

2.1.1 Mudança técnica e a abordagem evolucionária ...........................................................22

2.1.2 Regimes tecnológicos e trajetórias tecnológicas..........................................................29

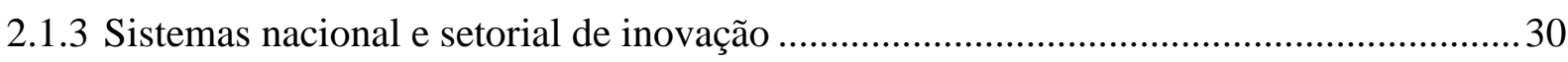

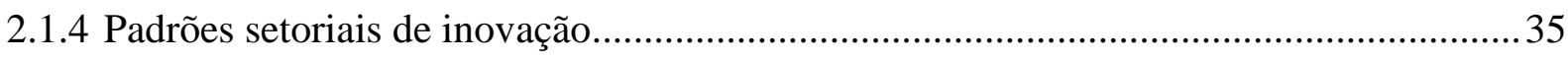

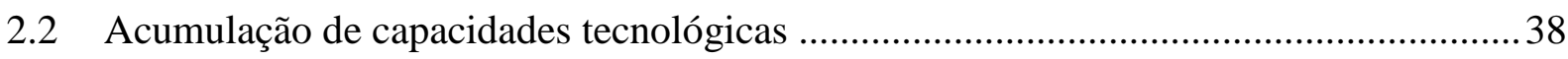

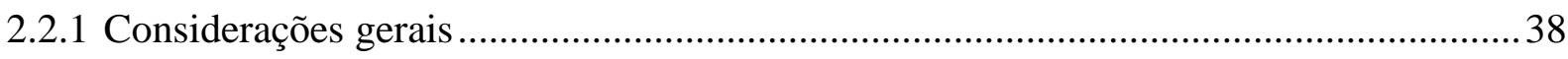

2.2.2 Principais estudos empíricos e métricas sobre capacidade tecnológica............................43

2.2.3 Trajetórias de acumulação de capacidade tecnológica.......................................................50

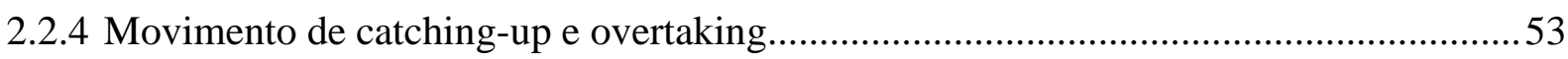

2.2.5 Estrutura do ambiente institucional: fontes para o aprendizado ......................................57

2.2.6 O papel das instituições e das políticas públicas............................................................... 60

2.2.7 Transferência tecnológica: o processo de transferência internacional de tecnologia .....62

2.3 A inovação no contexto da indústria brasileira: fragilidades e potencialidades .............. 64

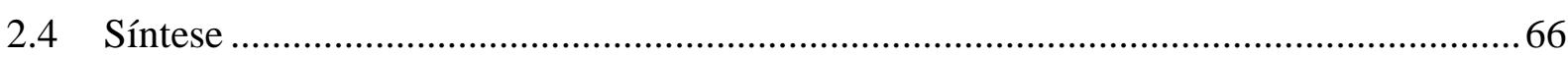

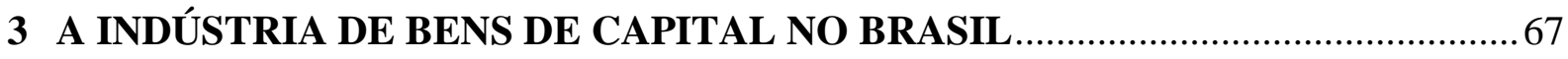

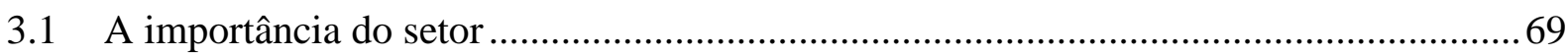

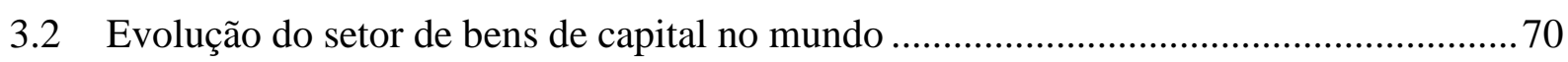

3.3 Desempenho da indústria de bens de capital no Brasil ................................................. 71

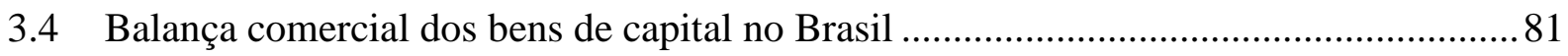

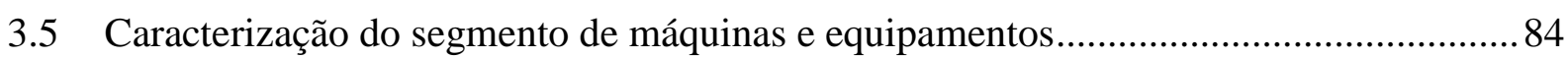

3.6 Síntese do desempenho da indústria de bens de capital no Brasil ..................................93

3.7 Dinâmica do setor de bens de capital ............................................................................ 94

3.8 Políticas tecnológicas para a indústria de bens e capital...............................................96

3.9 Década de 2000 em diante: articulação entre política tecnológica e política industrial 102

3.10 Política Nacional de Ciência, Tecnologia e Inovação - PNCT\&I ................................... 113

3.11 Políticas de incentivo à inovação tecnológica no Brasil ................................................114 
3.11.1 Conselho Nacional de Desenvolvimento Científico e Tecnológico - CNPq.....

3.11.2 Financiadora de Estudos e Projetos - FINEP

\section{MÉTODO DE PESQUISA}

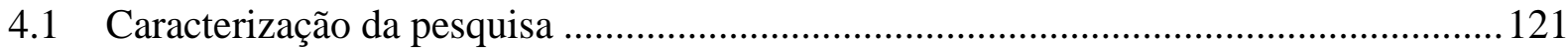

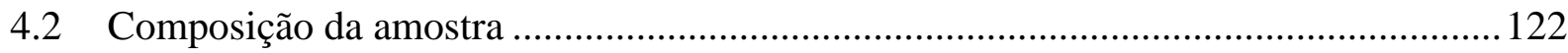

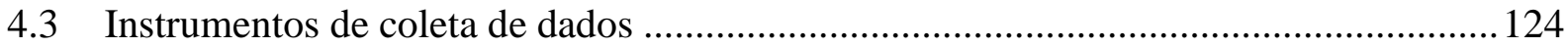

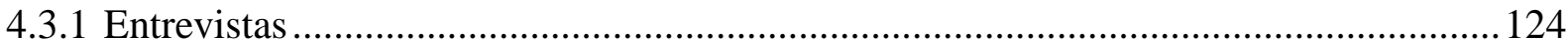

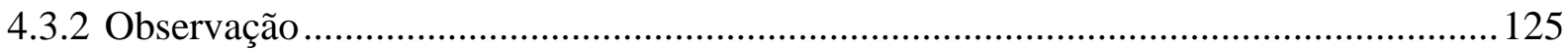

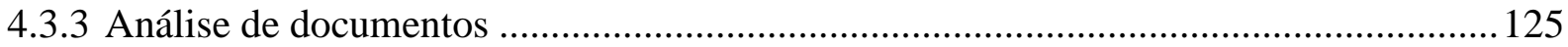

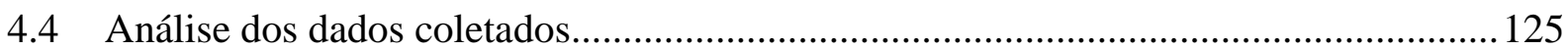

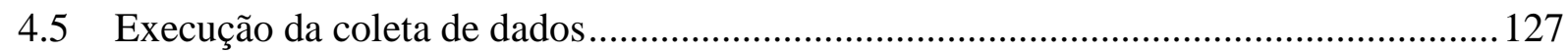

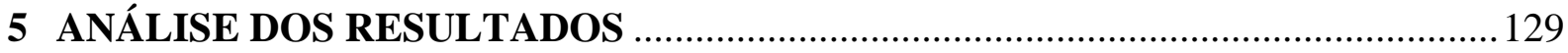

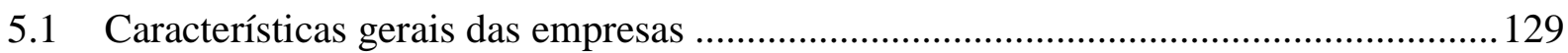

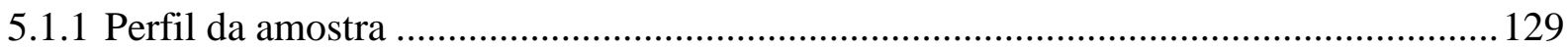

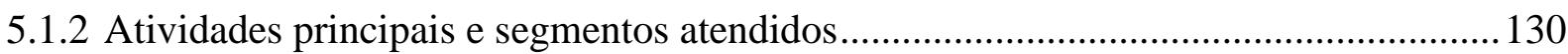

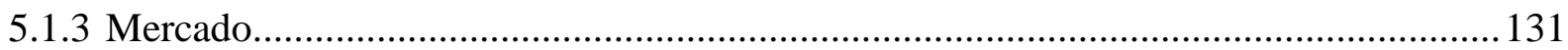

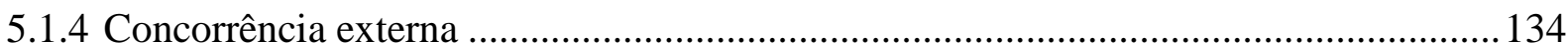

5.1.5 Conhecimento e monitoramento do ambiente externo................................................ 136

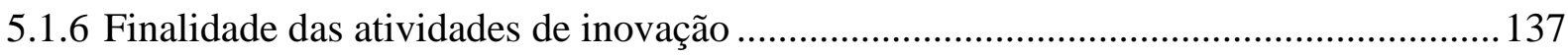

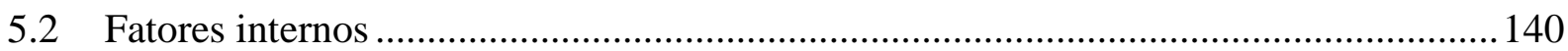

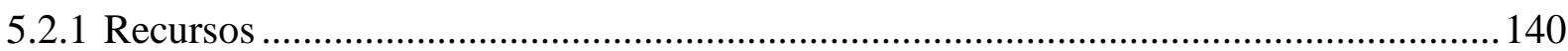

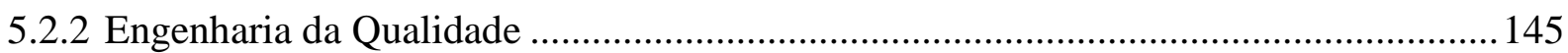

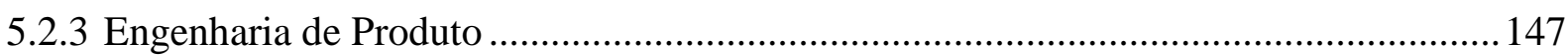

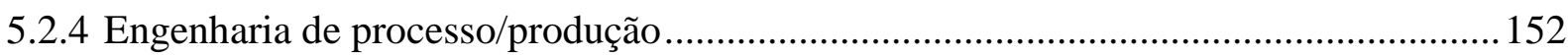

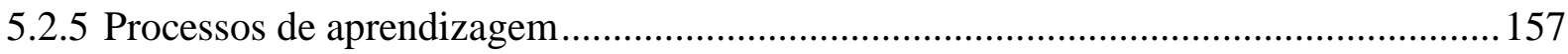

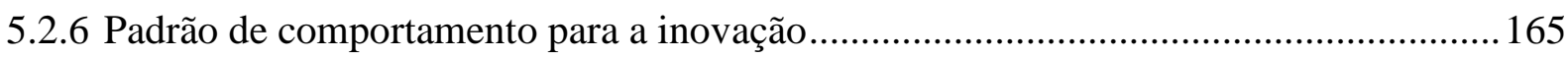

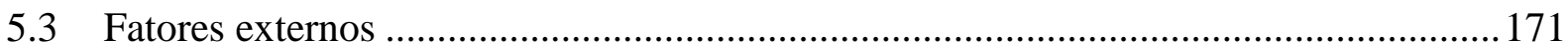

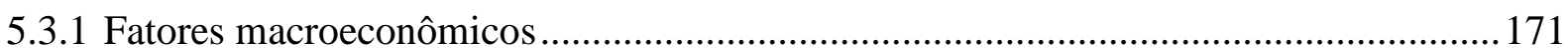

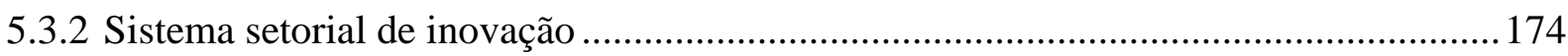

5.3.3 Síntese dos determinantes internos e externos da capacidade tecnológica ................... 177

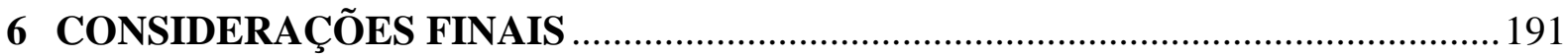

6.1 Limitações da pesquisa e sugestões para trabalhos futuros ....................................... 193

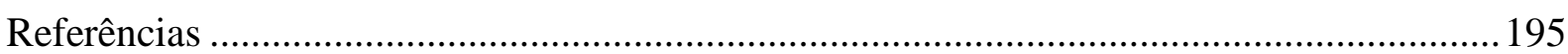

Apêndice A - Classificação das empresas segundo o CNAE ..............................................205

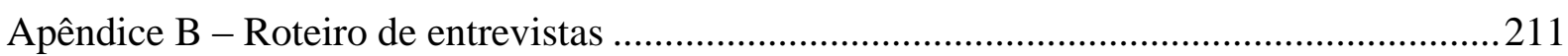


Apêndice C - Carta de apresentação às empresas .............................................................218 



\section{INTRODUÇÃO}

\subsection{Problema de pesquisa}

O conhecimento científico e a inovação tecnológica protagonizam, a partir da década de 1980, grandes transformações que mudaram de maneira radical produtos e processos, organização do trabalho, e formas de comunicação e de aprendizagem. Cada vez mais, é evidente o interesse dos países, sejam eles industrialmente avançados ou em desenvolvimento, em estabelecer estratégias de crescimento, inserindo como um de seus componentes principais as políticas de incentivo à inovação. Da mesma forma, intensos esforços analíticos têm sido realizados para o entendimento da dinâmica da inovação, e várias abordagens têm buscado compreender seus diferentes aspectos.

A dinâmica da mudança técnica pode ser entendida basicamente por dois pensamentos, representados pelos modelos linear e interativo de inovação. O primeiro, relacionado às teorias clássicas e neoclássicas sobre o crescimento e desenvolvimento econômico, considerou a tecnologia como sendo predominantemente de caráter exógeno, de acesso livre, onde a empresa é compradora de tecnologia. O modelo interativo, por sua vez, relacionado à teoria evolucionista, traz uma nova compreensão do processo de inovação. Nessa perspectiva, a tecnologia, ao contrário do modelo linear, é considerada de caráter endógeno, enfatiza a interdependência sistêmica entre os agentes econômicos, e destaca a capacidade das empresas e as habilidades individuais no processo de inovação.

A busca pelo entendimento da dinâmica da mudança técnica trouxe aos teóricos evolucionistas o conceito de regime tecnológico, o qual pode ser entendido como um modelo ou padrão de solução para os problemas tecnológicos. Um regime tecnológico específico define a natureza dos problemas que uma firma apresenta em relação as suas atividades inovativas; afeta o tipo de aprendizagem tecnológica e, por conseguinte, a dinâmica da evolução dessas firmas.

A natureza e a direção da mudança tecnológica, na nova abordagem evolucionista, conduziram os estudos à compreensão de regularidades setoriais nos determinantes da inovação. A relação entre inovação e evolução das indústrias tem sido o tema central nessa nova perspectiva, constatando grandes diferenças existentes através das diversas indústrias, tecnologias e países. As similaridades nos processos produtivos das firmas resultam em trajetórias tecnológicas também similares, permitindo o agrupamento das indústrias e a 
construção de categorias. Com isso, taxonomias setoriais têm sido criadas para interpretar os diferentes ritmos de mudança tecnológica.

A inovação difere através dos setores e através das firmas em termos de características, base de conhecimento, fontes e organização das atividades inovativas. Conforme Malerba (2006) há uma considerável heterogeneidade das firmas em termos de diferentes conhecimentos, competências e processos de aprendizagem. Sendo assim, cada setor da indústria compreende empresas que são mais inovadoras do que outras, empresas mais capacitadas e outras menos capacitadas, empresas com maior e menor potencial para inovação. A gama de variáveis que afetam a dinâmica da inovação envolve questões complexas, que são tanto internas quanto externas à firma.

Ao considerarmos as diferenças entre os setores, em especial nas formas de aprendizado e de mudança técnica, associadas à concepção de regime tecnológico, torna-se útil, na análise das firmas dentro de um mesmo setor, o conceito de Sistema Setorial de Inovação (SSI). Um SSI busca identificar, fundamentalmente, as principais dimensões e variáveis, que afetam a estrutura, a heterogeneidade e mudanças dos agentes. A estrutura de um sistema setorial foca o conhecimento e o domínio tecnológico; os atores e suas inter-relações; e as instituições, aqui entendidas como normas, rotinas, leis, padrões e prática existentes. Dessa forma, como as indústrias seguem uma dinâmica específica de inovação, torna-se imperativo considerar as especificidades do setor para análise da inovação no âmbito das empresas.

Laranja (2005) e Arnold et al. (2000), apontam que a aquisição de capacidades nas empresas, em especial as do tipo intangíveis, ou seja, aquisição de conhecimentos, aprendizagem e ampliação da base tecnológica das empresas, ocorre em torno de atividades, tais como as de aquisição de tecnologia, atividades de desenvolvimento tecnológico e de $\mathrm{P} \& \mathrm{D}$, que seguem uma escala de complexidade crescente.

Em outros termos, para atingir níveis mais elevados de capacidade tecnológica, a empresa começa por atividades simples e evolui progressivamente para capacidades mais avançadas. Entende-se por capacidade tecnológica de uma empresa ou setor industrial (Bell e Pavitt, 1995), como sendo os recursos necessários para gerar e gerenciar as mudanças tecnológicas, os quais estão incorporados nos indivíduos (habilidades, experiências, qualificações) e nos sistemas organizacionais (rotinas, procedimentos da firma).

Conforme Pavitt (1984), as firmas estão em diferentes níveis quanto à capacidade tecnológica, o que as leva a definir estratégias diferentes, segundo a disponibilidade e o acesso à 
tecnologia, aquisições, capacidade de apropriação privada dos resultados do progresso técnico, etc. Nesse sentido, a mudança técnica é entendida como um processo dinâmico e com uma natureza acumulativa. Tais considerações sugerem etapas ou estágios para a capacitação tecnológica, que evoluem de acordo com as características e fatores, que podem ser internos e externos às firmas.

No contexto brasileiro, pesquisas sobre inovação, capacidade tecnológica, padrões tecnológicos e desempenho das firmas brasileiras têm sido realizadas, o que demonstra um esforço significativo para o entendimento da complexidade e dos aspectos da inovação no país. Entretanto, a mobilização pela inovação no Brasil é ainda um fato recente, e do ponto de vista analítico, muitas lacunas ainda existem.

O setor de bens de capital, em especial, está presente na cadeia produtiva da maior parte dos setores industriais, atua como uma importante força motora do desenvolvimento econômico de um país e tem sua importância reconhecida no domínio, na criação e na difusão de tecnologias. Entretanto, nas últimas décadas, o setor brasileiro pouco se mobilizou para aumentar a capacidade tecnológica das empresas e as políticas adotadas, de maneira geral, não resultaram em grandes avanços tecnológicos para o setor. Como consequência, tem-se atualmente, um setor de bens de capital no Brasil que apresenta um gap (atraso) tecnológico em relação à fronteira internacional, com a maioria de suas empresas com baixos níveis de capacidade tecnológica. Por outro lado, a indústria brasileira de bens de capital possui um mercado interno de grande dimensão e enorme perspectiva de demanda futura, e apresenta grande potencial de crescimento e adensamento tecnológico.

Sendo assim, à luz da abordagem evolucionista, das concepções de regime tecnológico e de padrões e sistemas setoriais de inovação, este trabalho tem por objetivo principal analisar as dimensões internas e externas que determinam o acúmulo de capacidades tecnológicas das empresas.

\subsection{Objetivos da pesquisa}

Considerando a inovação no contexto atual brasileiro, a importância e a necessidade de gerar maior capacidade e adensamento tecnológico para a competitividade das empresas brasileiras do setor de bens de capital, este estudo tem por objetivo principal analisar os elementos determinantes internos e externos para o acúmulo da capacidade tecnológica em empresas de bens de capital no Brasil. 
Visa capturar evidências de capacidade tecnológica não apenas em empresas com níveis avançados (empresas que inovam, diferenciam produtos e se destacam no setor), mas também naquelas que apresentam níveis intermediários (empresas que apresentam esforços para inovação) e básicos (empresas que não inovam, mas com possibilidades de inovar).

\subsection{Justificativa e contribuição}

A indústria de bens de capital é uma das principais forças motoras do desenvolvimento econômico de um país. Está presente na cadeia produtiva da maior parte dos setores industriais, tendo sua importância reconhecida no domínio, na criação e na difusão de tecnologias. É responsável por fornecer produtos que são utilizados para fabricar outros produtos. À medida que incorpora uma parcela expressiva do progresso técnico, o difunde pelos demais setores produtivos, contribuindo, como um todo, para o crescimento econômico. Para países em desenvolvimento, como o Brasil, na maioria das vezes a incorporação do progresso técnico ocorre via aquisição de máquinas e equipamentos importados. No entanto, evidências empíricas no Brasil demonstram que uma segunda opção, orientada para fomentar o desenvolvimento de determinados segmentos com maior intensidade tecnológica, é mais apropriada para a incorporação do progresso técnico. A atual política industrial e tecnológica brasileira por meio de adoção de medidas que visam ao adensamento tecnológico e crescimento da produção nacional, bem como à elevação das exportações, já denota a opção por essa segunda via.

O Brasil já possui uma indústria de bens de capital relativamente constituída e um mercado interno de grande dimensão e enorme perspectiva de demanda futura em diversos segmentos da indústria. Entretanto, a indústria também apresenta um atraso tecnológico em relação à fronteira internacional. Os esforços de engenharia, de maneira geral, são limitados, e a tarefa tecnológica consiste na implementação de tecnologia estrangeira transferida para fabricar produtos, cuja tecnologia e mercado já existem.

Em outros termos, as empresas brasileiras adquiriram capacidade produtiva, que se refere aos recursos necessários para operar tecnologias existentes. $\mathrm{O}$ avanço para a diminuição do atraso e aproximação da fronteira tecnológica internacional requer capacidades não apenas produtiva, ou seja, para adquirir, assimilar e usar tecnologias existentes, mas capacidade inovativas, que compreende a gama de recursos para a geração e gerenciamento da mudança tecnológica. Nesse sentido é necessário desenvolver capacidades internas que levem a uma 
trajetória de aperfeiçoamento gradual da tecnologia e de desenvolvimento de capacidades para gerar novas tecnologias.

O acúmulo de capacidade tecnológica compreende aspectos que são internos e externos às empresas. Requer um engajamento nos processos de aprendizagem tecnológica, capacidades humanas e organizacionais, construção institucional e medidas políticas. Fatores externos, tais como o ambiente de mercado e tecnologia também influenciam o processo de aprendizado e os esforços para o fortalecimento das atividades internas e de acúmulo de capacidade tecnológica. No Brasil, a perspectiva sobre o processo de acumulação de capacidade tecnológica em empresas do setor de bens de capital tem sido pouco explorada, conforme destaca Figueiredo (2009). Sendo assim, uma análise aprofundada dos elementos internos e externos às empresas que conduza a um detalhamento das especificidades das empresas e do setor de bens de capital é de suma importante para delinear as principais barreiras e potencias que atuam no acúmulo da capacidade tecnológica das empresas.

No entanto, é importante destacar que os desafios para a expansão do setor são grandes e incluem o fortalecimento do desenvolvimento tecnológico, o aumento de escala de produção e do grau de internacionalização, dentre outros. Esta pesquisa visa contribuir no atendimento dessas necessidades e no desafio de se construir uma indústria de bens de capital mais próxima a dos países mais avançados no setor. A possibilidade de identificar as competências e suas carências quanto à capacidade tecnológicas das empresas permitirá o entendimento das condições que favorecem e inibem as empresas para a mudança técnica e de patamar tecnológico, e, por conseguinte servir de apoio na formulação de políticas públicas mais direcionadas e próximas à realidade e necessidades das empresas.

\subsection{Delimitação do escopo do trabalho}

O tema capacidade tecnológica é amplo e compreende várias abordagens, as quais têm tratado o temo em nível macro e em nível micro. Este estudo, apesar de abordar aspectos em nível macro, concentra-se nas capacidades tecnológicas em nível de empresas, com ênfase nos componentes de capacidade humana e organizacional.

As análises e as empresas participantes restringem-se ao setor de bens de capital mecânico, segundo definição do CNAE - Código Nacional de Atividade Econômica. 
Quadro 1: Delimitação do escopo do trabalho

\begin{tabular}{|l|l|}
\hline \multicolumn{1}{|c|}{ Dimensões } & \multicolumn{1}{c|}{ Delimitação } \\
\hline Unidade de análise & Micro: capacidade tecnológica em nível de empresas \\
\hline Abordagem sobre inovação & $\begin{array}{l}\text { Perspectiva neoschumpeteriana } \\
\text { Empresas fabricantes instaladas no Brasil }\end{array}$ \\
\hline \multirow{2}{*}{ Empresas investigadas } & $\begin{array}{l}\text { Setor de bens de capital mecânico brasileiro } \\
\text { Grupo CNAE 28.1- Fabricação de motores, bombas, compressores e } \\
\text { equipamentos de transmissão; } \\
\text { Grupo CNAE 28.2 - Fabricação de máquinas e equipamentos de uso geral; } \\
\text { Grupo CNAE 28.4 - Fabricação de máquinas-ferramentas; } \\
\text { Grupo CNAE 28.6 - Fabricação de outras máquinas e equipamentos de uso } \\
\text { específico. }\end{array}$ \\
\hline
\end{tabular}

O Quadro 1 sintetiza o escopo deste trabalho. A perspectiva sobre inovação adotada para a pesquisa é a neoschumpeteriana, pois possui uma abrangência maior sobre inovação e destina à tecnologia um caráter dinâmico e endógeno.

Vale ressaltar que o objetivo deste trabalho centra-se nas capacidades tecnológicas, não fazendo parte da análise considerações sobre as capacidades não tecnológicas, tais como marketing e finanças, embora sejam de grande importância para o desempenho das empresas.

Por outro lado, não foi objetivo deste trabalho mensurar o grau ou nível de capacidade tecnológica das empresas, o foco recaiu sobre os principais elementos, internos e externos a elas, que de alguma forma atuam como fatores inibidores ou motivacionais para o acúmulo de capacidade tecnológica.

\subsection{Estrutura do trabalho}

Este trabalho é constituído por 4 capítulos, além do capítulo 1, introdutório. Está dividido em três partes. Uma primeira parte, que apresenta os capítulos com a fundamentação teórica envolvida no desenvolvimento do tema da pesquisa; uma segunda parte, com o capítulo que apresenta o método de pesquisa utilizado no trabalho; e a uma terceira parte, com capítulos que apresentam a análise dos resultados e as considerações finais. Em seguida, o trabalho é finalizado com as referências bibliográficas utilizadas e os apêndices. A figura 1 faz uma representação da organização do estudo deste trabalho reunindo seus capítulos abordados. 


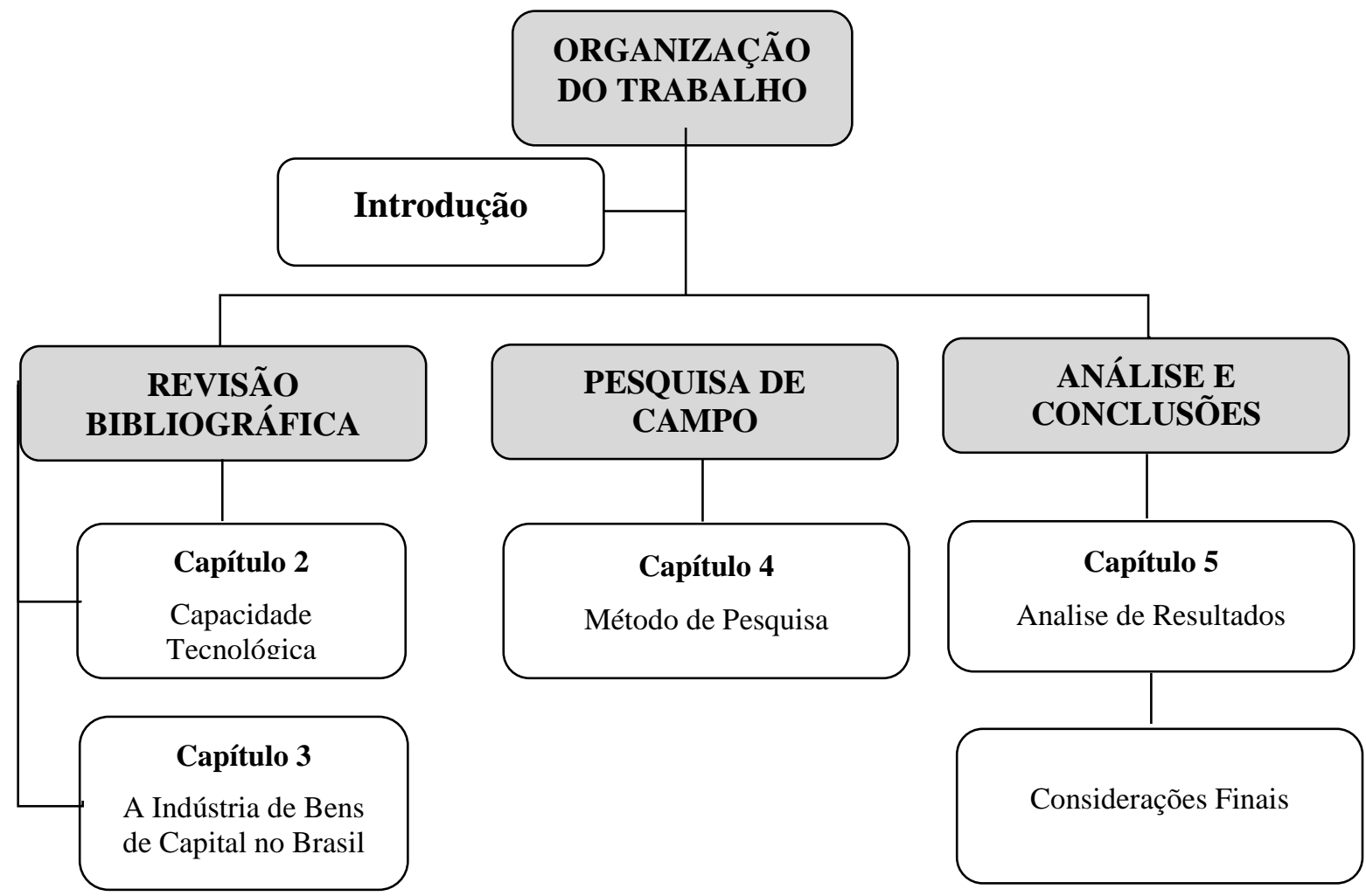

Figura 1: Organização do trabalho Fonte: Elaborado pelo autor

O capítulo 2, Capacidade Tecnológica, apresenta inicialmente aspectos gerais sobre a inovação. São feitas também algumas considerações sobre a inovação no contexto brasileiro, enfatizando suas principais fragilidades e potencialidade. Em seguida, apresenta-se a abordagem evolucionária ou neoschumpeteriana, cujos elementos constituintes, tais como regimes e trajetórias tecnológicas, sistema de inovação e padrões setoriais de inovação, apoiam este trabalho. Em seguida, são apresentados os conceitos e suas principais características. Após a exposição do conceito, são mostrados e discutidos os principais estudos e métricas sobre a capacidade tecnológica, com ênfase nas trajetórias de acumulação em países desenvolvidos e em desenvolvimento.

O capítulo 3, A Indústria de Bens de Capital, inicia apresentando a importância do setor e um breve panorama mundial do setor. Em seguida, o capítulo apresenta um histórico sobre o desempenho da indústria de bens de capital no Brasil, desde o período pós-guerra. O objetivo é mostrar o papel do setor no desempenho econômico do país e as implicações (ou efeitos) das políticas adotadas, ao longo do tempo, para o seu crescimento.

O capítulo 4, Método de Pesquisa, delineia a metodologia empregada na pesquisa e as técnicas e instrumentos de coleta de dados utilizados. 
O capítulo 5, Análise de Resultados, Apresenta o trabalho de campo, com a descrição e análise dos dados coletados.

Por fim, são apresentadas as considerações finais e as limitações da pesquisa e sugestões para trabalhos futuros. 


\section{CAPACIDADE TECNOLÓGICA}

\subsection{Mudança técnica e inovação}

A inovação justifica, em grande parte, o sucesso das empresas. As organizações que conseguem mobilizar conhecimento e avanços tecnológicos e conceber a criação de novidades em suas ofertas (produtos/serviços) e nas formas como criam e lançam essas ofertas, são favorecidas no cenário atual.

Uma inovação, segundo o Manual de Oslo (OECD, 2005), é a implementação de um produto (bem ou serviço) novo ou significativamente melhorado, ou um processo, ou um novo método de marketing, ou um novo método organizacional nas práticas de negócios, na organização do local de trabalho ou nas relações externas. A definição acima leva a uma divisão da inovação em quatro áreas ou tipos, a saber: produto, processo, marketing e organização.

As inovações de produto envolvem a introdução de um bem ou serviço que é novo ou significativamente melhorado. As inovações de processo representam mudanças significativas nos métodos de produção e de distribuição.

Outra categorização ou tipologia de inovação é apresentada por Tidd et al. (2008):

- Inovação de produto: mudanças nas coisas (produtos /serviços) que uma empresa oferece;

- Inovação de processo: mudanças na forma em que os produtos/serviços são criados e entregues;

- Inovação de posição: mudanças no contexto em que produtos/serviços são introduzidos;

- Inovação de paradigma: mudanças nos modelos mentais subjacentes que orientam o que a empresa faz.

Outra dimensão que compreende a inovação é o grau de novidade envolvido. Dentre os diferentes tipos destacam-se: a) inovação incremental, que envolve adaptações ou melhorias de produtos/serviços/produção existentes, por exemplo, a próxima geração de um microprocessador; b) inovação radical, que compreende a criação de um produto/serviços/produção totalmente novo. Um exemplo é a comunicação do tipo wireless; c) inovação arquitetural, que se refere à reconfiguração do sistema de componentes que constituem o produto, como por exemplo, os efeitos da miniaturização dos componentes do rádio. 
Ao se analisar o contexto brasileiro, é importante destacar que os mecanismos de geração de inovações possuem deficiências ou diferem entre os mesmos setores das economias desenvolvidas e emergentes. O próprio sentido do conceito de inovação assume caráter distinto em tais países, pois, em sua maioria, são adaptações de produtos e processos já existentes em outras partes do mundo ou simplesmente são novos apenas para a empresa que os produz.

A origem do processo de inovação tecnológica ocorre pelas invenções ou descobertas. Conforme Burgelman, Christensen e Wheelwright (2009), as invenções são resultados do processo criativo que frequentemente são muito difíceis de serem previstos ou planejados. Nesse sentido, a pesquisa científica (básica e aplicada), desenvolvida nas universidades, assume um importante papel nesse processo. A pesquisa científica básica atua nas atividades que envolvem a geração de novos conhecimentos sobre o fenômeno físico, biológico e social, enquanto que a pesquisa cientifica aplicada, se adapta à solução de determinados problemas técnicos. Assim sendo, o critério para o sucesso nas invenções e descobertas é puramente técnico.

No que se refere à tecnologia, o critério para seu sucesso também é técnico. A tecnologia diz respeito ao conhecimento teórico e prático e habilidades que podem ser usadas no desenvolvimento de produtos e serviços bem como em seu sistema de produção. Ela pode ser vista como o resultado do desenvolvimento de atividades que colocam no uso prático as invenções e descobertas. A tecnologia pode estar incorporada nas pessoas, materiais, equipamentos e ferramentas.

Diferentemente das invenções e descobertas e da tecnologia, o critério para o sucesso da inovação tecnológica, não é técnico, e sim comercial. Em outros termos, seu sucesso exige um retorno de investimento adicional que vai além daquele despendido originalmente; requer um mercado amplo suficientemente para que a inovação seja desenvolvida.

O desenvolvimento de inovações implica na utilização das diferentes formas de aprendizado para a promoção do processo inovativo dentre as quais destacam-se: (i) learning-by-using (aprendizado por uso), relacionado à adaptação da empresa a novas tecnologias; (ii) learningby-doing (aprendizado por experiência), que ocorre nas atividades rotineiras das firmas, é relacionado ao processo produtivo da empresa; (iii) learning-by-searching (aprendizado por pesquisa), que ocorre a partir das atividades formais de $\mathrm{P} \& \mathrm{D}$, voltadas à criação de novos conhecimentos; (iv) learning-by-imitating (aprendizado por imitação), gerado pela reprodução de inovações de outra empresa; (v) learning-by-interacting (aprendizado por interação), 
através da relação da empresa com seus clientes, fornecedores, concorrentes, centros de pesquisa e universidades.

No entanto, para o caso da indústria brasileira vale destacar que o conceito e a utilização dos processos de aprendizagem incorporam características particulares. Conforme Viotti (2002), em países de industrialização tardia, como o Brasil, os investimentos, principalmente aqueles realizados por empresas transnacionais, para a incorporação de novas técnicas aos processos produtivos através da aquisição de tecnologias externas, na realidade não estariam gerando capacidade inovativa, mas apenas modernizando o aparato produtivo. O que ocorre é um melhoramento das inovações produzidas nos países desenvolvidos, ou seja, tem-se o desenvolvimento de um aprendizado tecnológico, e não de uma inovação, propriamente dita. Sendo assim, o conceito de aprendizado passa a incorporar outros dois conceitos, que são fundamentais para a dinâmica da industrialização tardia: o conceito de difusão e de inovação incremental. Nesses termos, o aprendizado é definido pelo processo de mudança técnica obtida pela difusão e pela inovação incremental, ou seja, ocorre pela absorção de técnicas já existentes, que permitem a geração de melhorias na fronteira das técnicas adquiridas.

\subsubsection{Mudança técnica e a abordagem evolucionária}

O conceito de mudança técnica está relacionado ao lançamento ou aprimoramento de produtos, processos produtivos, métodos gerenciais ou uso de insumos e matérias-primas modificadas. Passou a ser tratada como elemento central para a explicação da dinâmica da economia capitalista, na primeira metade do século passado, a partir dos trabalhos de Schumpeter e de seus seguidores. Para Schumpeter (1982), a mudança técnica foi interpretada como um processo que compreende três estágios: invenção, inovação e difusão. A invenção, conforme mencionado acima, não busca a exploração comercial, enquanto que a inovação sim. Sob o ponto de vista econômico, a inovação só se concretiza quando de sua primeira transação comercial. A difusão, por seu turno, trata de como novos produtos ou processos se propagam pelos mercados potenciais.

A abordagem evolucionista, que decorre da visão de organização do sistema econômico sustentada por Schumpeter, tem como principal característica a incorporação do fenômeno da mudança tecnológica, explicando como a produção das atividades técnico-científicas é incorporada ao processo produtivo e quais são os efeitos dessa incorporação sobre a própria estrutura industrial e de concorrência (HASENCLEVER E MENDONÇA, 1994). Vários estudos procuraram enfatizar o papel da capacidade tecnológica como fonte de diferenças entre os setores industriais e países, em termos de progresso industrial e de crescimento 
econômico. Tais diferenças de desempenho tecnológico e econômico devem-se principalmente ao caráter tácito e intrínseco da tecnologia, o que impossibilita sua transferência automática de um contexto para o outro.

A análise do progresso técnico na abordagem evolucionista encontra um espaço aberto para elaboração, que extrapola as abordagens mais tradicionais de demand-pull e technology-push, ambas elaboradas sobre o paradigma neoclássico. A abordagem demand pull apresenta um conceito reativo das mudanças técnicas às condições de mercado, sem explicar o tempo das inovações e a descontinuidade de seus padrões, e desconsidera a complexidade e o papel da incerteza no processo inovativo. A abordagem technology push, por sua vez, considera a ciência exógena e neutra na interação com a tecnologia e a economia. Os teóricos evolucionistas avançam alguns passos na direção de incorporar esses elementos na análise do progresso técnico, na medida em que introduz a noção de conduta (comportamento) da empresa e reconhece a existência de assimetrias (heterogeneidades) na estrutura industrial. As simetrias entre as firmas e entre os setores (em termos de capacidade tecnológica, capacidade inovadora e rapidez na imitação) são, por um lado, condições de incentivo à atividade inovadora e, por outro, o próprio resultado dessas atividades. A existência de tais assimetrias setoriais é um dos componentes que explicam a escolha de diferentes estratégias (HELLER, 1991).

Diante do entendimento de que o progresso técnico dinamiza as transformações estruturais, torna-se necessário descrever o ambiente tecnológico de atuação da firma, bem como compreender os processos de geração e difusão das inovações tecnológica. Dosi (1988), afirma que cada firma apresenta oportunidades tecnológicas diferentes, já que as condições de oportunidades podem altas ou baixas, o conhecimento aplicado pode ter alta ou baixa penetração e o acesso às fontes de informações pode ser fácil ou difícil. Assim, a definição de um único padrão de inovação tem sido apontada pela literatura como sendo impossível. Orsenigo (1995), também mostra que há uma variedade e diferentes graus de tecnologia que podem ser observados inter e intra-segmentos produtivos e que se manifestam a partir das propriedades da tecnologia e das características dos processos de aprendizado que estão envolvidos nas atividades econômicas. Nota-se, então, a existência de dinâmicas industriais diferenciadas em critérios de busca e seleção de inovação, formas de aprendizado, vínculo com a ciência, capacidade de proteção de inovação, relação de cooperação, e interação entre firmas. Vários pesquisadores (Breschi e Malerba, 1997; Malerba e Orsenigo, 1997; Pavitt, 1984) têm mostrado distintas capacidades de uma indústria ou grupo de indústrias em 
absorver, desenvolver e transferir tecnologias, definindo assim diferentes padrões setoriais de inovação.

\subsubsection{Regimes tecnológicos e trajetórias tecnológicas}

A análise do processo competitivo, na visão neo-schumpeteriana, requer a compreensão dos conceitos de regime tecnológico e de trajetória tecnológica, uma vez que estes permitem entender a dinâmica da inovação e da obtenção de ganhos de competitividade (LA ROVERE, 2006).

As concepções teóricas denominadas demand pull e tecnology push apresentam limitações e falham ao tentar explicar os principais determinantes da mudança técnica e a inovação. $\mathrm{Na}$ tentativa de superar essas limitações e de formular uma referência que permita explicar a natureza do processo de mudança tecnológica, os teóricos da abordagem evolucionista propõem o conceito de regime tecnológico e trajetória tecnológica, denotando, assim, a existência de fortes similaridades entre a natureza e os procedimentos da ciência e tecnologia. Nesse sentido, as mudanças tecnológicas ocorrem o tempo todo, de maneira endógena, dentro da firma.

O conceito de regime tecnológico foi introduzido por Nelson e Winter (1977) e elaborado por Dosi (1982), e define os princípios do conhecimento científico e tecnológico que são necessários para o processo de inovação, bem como as fronteiras que podem ser alcançadas. Literalmente, é um modelo ou padrão de solução para os problemas tecnológicos selecionados a partir de um processo de aprendizagem tecnológica, de resoluções que envolvem princípios científicos e procedimentos tecnológicos.

Em outros termos, o regime tecnológico pode ser definido em termos da combinação específica das condições de (i) oportunidade tecnológica (facilidade com a qual, novas soluções tecnológicas podem surgir), (ii) condições de apropriabilidade (facilidade com a qual, novas soluções podem ser protegidas contra as imitações), (iii) nível de cumulatividade do aprendizado (aprendizado obtido com inovações passadas influencia as inovações que ocorrerão no futuro), e (iv) natureza da base de conhecimento (propriedades do conhecimento no qual as atividades inovativas das firmas estão baseadas) (DOSI, 1988; MALERBA e ORSENIGO, 1993; MARSILI e VERSPAGEN, 2001).

Sua estrutura teórica contribui para a compreensão da variedade de processos de inovação que é observada através dos setores industriais e da própria tecnologia. Em outros termos, o regime tecnológico descreve o ambiente tecnológico no qual as firmas operam e enfatiza a 
importância dos padrões setoriais na mudança tecnológica. De acordo com Malerba (2002), um regime tecnológico específico define a natureza dos problemas que uma firma apresenta, em relação as suas atividades inovativas; afeta o tipo de aprendizagem tecnológica e, por conseguinte, a dinâmica da evolução dessas firmas. Vários outros estudos, em especial Malerba e Orsenigo (1996), Breschi, Malerba e Orsenigo (2000), e Van Dijk (2000) desenvolveram pesquisas empíricas sobre regimes tecnológicos a partir do modelo de Nelson e Winter.

Conforme enfatizado por Silva e Hasenclever (2014), em regimes tecnológicos cujos parâmetros facilitam (dificultam) a imitação e a transferência de tecnologia, isto é, regimes em que as firmas possuem alto (baixo) grau de capacidade absortiva com pouco (alto) esforço de aprendizagem tecnológica, é intuitivo imaginar que as indústrias irão evoluir para um padrão de estratégia inovativa com baixa (alta) intensidade de P\&D.

Em consequência do regime tecnológico, surge a noção de trajetória tecnológica, que pode ser definida, conforme Dosi (1982), como um padrão ou modo de progresso, por meio da solução incremental dos trade-offs multidimensionais entre as variáveis tecnológicas que o paradigma tecnológico define como relevantes. Dentro de um regime tecnológico, são desenvolvidas trajetórias tecnológicas, sendo que a mudança de um regime implica a mudança da trajetória tecnológica.

\subsubsection{Sistemas nacional e setorial de inovação}

A abordagem conceitual de Sistema Nacional de Inovação (SNI) emergiu como uma das correntes dominantes de pesquisa do campo de estudos sobre inovação, com a preocupação de explicar o crescimento tecnológico em uma economia de forma mais eficaz. A crise, na década de 1980, do modelo de industrialização por substituição de importação, bem como a do Estado de suas políticas, contribuíram para a busca de um novo entendimento do crescimento e desenvolvimento econômico, nos países em desenvolvimento.

Lundvall et al. (2009, p.4) mostra que são várias as definições de sistema nacional de inovação colocadas pela literatura, mas enfatiza que todas apresentam em comum a presença de instituições, das relações entre os diversos tipos de atores econômicos, e foco no conhecimento e na tecnologia. Para Freeman (1987), um SNI é uma rede de instituições públicas e privadas, cujas atividades e interações iniciam, importam, modificam e difundem novas tecnologias. Para Lundvall (1992), compreende, fundamentalmente, os elementos e relações que interagem na produção, difusão e uso de novos conhecimentos. Conforme 
Nelson e Rosenberg (1993) é o conjunto de instituições cujas interações determinam o desempenho inovativo das firmas nacionais. Pelas definições acima pode-se observar, na primeira, o entendimento de que a inovação vai além da firma, e a importância de sua propagação no sistema econômico.

Na segunda e terceira definições, tem-se o foco na relevância das interações entre os agentes para a dinâmica da inovação, e no papel das instituições. Vale destacar também a importância de se colocar o Estado no papel central do processo de inovação (geração, difusão e uso) para o desenvolvimento econômico. Tais considerações conceituais vão ao encontro de uma conclusão central na literatura sobre inovação, que afirma que (comum a todos os tipos de inovação) na maioria dos casos, as atividades de inovação dependem fortemente de fontes externas, ou seja, os inovadores raramente inovam isoladamente, comumente precisam trabalhar em conjunto com outras entidades para desenvolver uma inovação.

De fato, conforme Cimoli et al. (2006), todos os processos de geração de novos conhecimentos científicos e tecnológicos, tanto quanto os de imitação e adaptação tecnológica, envolvem uma ampla variedade de atores complementares, frequentemente incluindo empresas mercantis, mas, junto com elas, instituições públicas de pesquisa e treinamento, "comunidades de intercâmbio", sociedades técnicas e sindicatos, entre outros. Nesse sentido, sistemas nacionais de produção e de inovações devem considerar, em sua constituição, as instituições e políticas voltadas para o aprendizado tecnológico.

Outro aspecto importante em relação ao sistema nacional de inovação são as diferentes abordagens que se apresentam. Lundvall et al (2009, p.3) destacam uma abordagem do SNI restrita e uma ampla. A abordagem restrita de SNI tem como foco os atores clássicos, tais como empresas, instituições de pesquisa e universidades, e nos indicadores também clássicos de Ciência e Tecnologia, tais como P\&D, patentes e artigos. Tal visão está relacionada ao modo STI (Science, Technology, Innovation) de inovação. Este modo foca a inovação baseada em esforços de P\&D, sugerindo um modelo de inovação apoiado na experimentação (tipicamente em laboratórios), formalização e codificação do conhecimento identificado.

Entretanto, o modo STI constitui somente um dos pilares da aprendizagem e processo de inovação. No caso de a aprendizagem envolver conhecimento tácito e localizado, tem-se o modo DUI (Doing, Using, Interacting), que é mais amplo. O modo DUI tem seu foco na aprendizagem interativa, através de relações com o ambiente externo. A abordagem ampla de SNI considera a presença de instituições sociais, regulação macroeconômica, a integração 
com o sistema financeiro, o desenvolvimento de um sistema educativo e de treinamento, e requer também a existência de infraestrutura e condições de mercado.

Implicitamente, as definições especificam a importância da construção de competências para a promoção do processo de inovação. Entende-se como crucial para os processos de aprendizagem, a criação de capacidades nas empresas e a formação de competências de pessoal. Em outros termos, pode-se afirmar, conforme Lundvall et al (2009, p.6), que a inovação e a aprendizagem são o resultado de esforços que combinam instituições com uma estrutura socioeconômica.

Apesar de o foco inicial dos estudos sobre SNI terem uma abordagem em nível nacional, temse também uma vertente regional e setorial. Há um entendimento de que o sistema de inovação pode ser interpretado em nível regional/setorial e não só nacional. Esta justificativa apoia-se no preceito de que o conhecimento é localizado e que a aproximação geográfica facilita a interação e é fundamental para a promoção do aprendizado e de um ambiente favorável aos processos de inovação (Lundvall et al.,2009, p.8).

Os fundamentos do conceito de Sistema Setorial de Inovação (SSI) estão nas diferenças entre os setores nas formas de aprendizado e de mudança técnica, associadas à definição de regime tecnológico. Um sistema setorial de inovação (e produção) é composto por um conjunto de agentes heterogêneos que desenvolvem interações de caráter mercadológico ou nãomercadológico para a geração, adoção e uso de novas (ou já estabelecidas) tecnologias específicas e para a criação, produção e uso de novos produtos pertinentes a um setor (produtos setoriais). Os agentes que compõem um sistema setorial podem ser organizações (clientes, fornecedores, fabricantes, universidades, instituições financeiras, agentes governamentais, etc.) e indivíduos (MALERBA, 2002).

Tal abordagem ganha muita importância, em especial, para os países em desenvolvimento, pois possibilita o entendimento de como as capacidades são desenvolvidas pelas empresas e setores no sentido de inovar e competir. O desenvolvimento de setores, a partir de escolhas acertadas, é fundamental para o desenvolvimento econômico do país. Nesse sentido, o SSI pode contribuir substancialmente para o desenvolvimento econômico, já que através desse modelo é possível identificar os elos faltantes, os gargalos na circulação do conhecimento e as causas de falhas no sistema. Deste modo, a especialização do SSI em alguns setores (mais dinâmicos tecnologicamente) pode ser um fator determinante para o dinamismo econômico. 
Essa potencialidade do SSI, conforme Lundvall et al (2009, p.8), tem justificado, cada vez mais, a adoção desse modelo por países em desenvolvimento. Mas é importante enfatizar que para que isso ocorra, é também necessário a criação de instituições adequadas, uma coordenação do sistema e a existência de uma infraestrutura capaz de apoiar e promover os processos.

A definição de SSI enfatiza, conforme Malerba (2002), alguns pontos que o distingue do conceito tradicional de setor, pois analisa outros agentes além das firmas. Dentre os principais pontos, destacam-se:

- O sistema setorial privilegia o conhecimento e sua estrutura como elemento-chave. A base de conhecimento pode muito diferenciar-se através dos setores e afetar as atividades inovativas, organização e comportamento das firmas dentro de um setor;

- São enfatizados aspectos-chave da firma, tais como processo de aprendizagem, competências, comportamento e organização. A ênfase em identificar o grau e os determinantes da heterogeneidade dos agentes, comportamento e variedade organizacional dentro dos setores é uma característica da abordagem do sistema setorial;

- Importância do papel de organizações, tais como universidades, agentes financeiros, governo, e de regulações, padrões e mercado de trabalho. Estas características diferem fortemente entre os setores e afetam as atividades inovativas e produtivas das firmas;

- Mecanismos de interações internas e externas à firma. Relações entre os agentes, sejam elas de mercado ou não.

Em síntese, a noção de sistema setorial põe ênfase na estrutura do sistema, em termos de produto, agentes, conhecimento e tecnologia, e em sua dinâmica e transformação.

Com igual ênfase, Oyeleran-oyeyinka e Rasiah (2009) apontam como elementos chave de um sistema setorial de inovação os agentes econômicos (atores) e as instituições (incluindo instrumentos e organizações), e identificam quatro pilares, conforme apresentados abaixo, necessários para direcionar a sinergia entre aprendizagem e inovação e dar sustentação ao processo de catching-up.

Estabilidade e eficiência: referem-se à infraestrutura básica eficiente, estabilidade macroeconômica e eficiência burocrática e segurança. Este pilar é essencial para os agentes operarem em qualquer setor. $O$ foco neste pilar é também importante para a condução da aprendizagem e inovação. Implica em fornecer menores custos de transação para que seus 
agentes econômicos sejam mais competitivos. A instabilidade política e ineficiência burocrática podem enfraquecer severamente a capacidade das empresas a buscarem participação em atividades de alto valor agregado.

Coesão: refere-se à conectividade entre os agentes econômicos e instituições, a interatividade e interdependência no fluxo de conhecimento entre pessoas, empresas e instituições. Para tal, é requerido o fornecimento de serviços tais como energia, serviços de telecomunicação, educação, instituições de capacitação, laboratórios de P\&D, entre outros.

Aprendizado e inovação: envolve a participação de agentes econômicos (indivíduos, empresas e instituições) que aprendem e inovam. A infraestrutura de alta tecnologia fornece o ambiente que estimula a aquisição de tecnologia seja através da aprendizagem (em particular a do tipo “learning-by-doing"), licenciamentos, adaptação, treinamento, etc. o sistema de inovação reconhece que o aprendizado em suas mais diversas formas (por imitação, por busca, por interação, por treinamento, etc.). Embora todas essas formas sejam importantes, o sucesso no sistema de inovação é caracterizado pelo alto grau de aprendizagem interativa. Logo, a presença de instituições de alta tecnologia, incentivos (incluindo subsídios), empresas de capital de risco e organizações de normalização, é vital para a mudança de patamar de economia subdesenvolvida para uma economia madura.

Integração global: refere-se à integração global através dos mercados e de cadeias produtivas globais. Mercados globais fornecem economias de escala e escopo e a pressão competitiva para inovar. Enquanto que a acumulação da aprendizagem e inovação abrem o caminho para posterior aprendizagem e conhecimento (acumulação criativa), a exposição em mercados globais conduz a uma substituição de tecnologias obsoletas e empresas, por novas. Nesse processo as empresas transnacionais podem contribuir substancialmente ao aprendizado.

Conforme Oyeleran-oyeyinka e Rasiah (2009), os países que se apoiaram nos quatro pilares lograram o catching-up, enquanto que os países que reforçaram parcialmente os pilares, não superaram o patamar de zona de exportação.

Entretanto, a aplicação do referencial de SNI para países em desenvolvimento é rejeitada por alguns autores tais como Viotti (2002) e Matthews (1999). Segundo Viotti (2002, p.653), a estrutura teórica e conceitual de SNI não é apropriada para lidar com o processo de mudança técnica, típica de economias em desenvolvimento, já que são extremamente diferentes daquelas de países industrializados. Destaca também que ambas as abordagens, restrita e ampla, de SNI são, de certa maneira, inapropriadas para o estudo de economias em 
desenvolvimento. A abordagem de SNI, para os países desenvolvidos, está fortemente voltada para a geração de inovações, especialmente as do tipo radicais, enquanto que nos países em desenvolvimento, as inovações incrementais e a difusão das inovações têm sido consideradas como mais relevantes.

Para Viotti (2002, p. 657), o processo de mudança técnica liderado por inovações é um privilégio de países industrializados, enquanto que o processo de mudança técnica de economias em desenvolvimento, geralmente, limita-se à absorção e incrementos de inovação produzidos nos países desenvolvidos. Sendo assim, é reconhecida a forte associação existente entre inovação incremental e difusão, caracterizando assim um processo de aprendizagem. Nesse sentido, Viotti (2002, p. 657) sinaliza a importância de se adotar nos países em desenvolvimento um conceito distinto, o de Sistema Nacional Aprendizagem, englobando ambos os elementos. Assim, a dinâmica para os países em desenvolvimento tem como seu pilar, a aprendizagem tecnológica, ao invés de inovação.

As considerações expostas acima nos levam a entender que a os sistemas nacionais de inovação e suas vertentes regionais e setoriais podem contribuir para o crescimento econômico em países em desenvolvimento. E, apesar das controvérsias em relação à sua aplicação, o SNI pode ser visto, não apenas como um conceito, mas como uma ferramenta para formulação de políticas. Deve-se, no entanto, se ter em mente que, como essas abordagens são construídas a partir de experiências e análises em países desenvolvidos, sua aplicação em contextos mais críticos como os de países periféricos, devem superar barreiras e desafios de adaptação, já que a difusão de progresso técnico é desigual entre os países e regiões. A estratégia para um bom desempenho de aplicação de um SNI, conforme visto,

passa por escolhas setoriais acertadas e por um conjunto de ações que promovam a capacidade de inovar. É relevante o papel ativo do Estado, a criação de uma cultura nacional de inovação (com seu entendimento sistêmico), e de igual importância, o fortalecimento de uma estrutura social, com atuação na distribuição de renda e no nível educacional.

\subsubsection{Padrões setoriais de inovação}

Peneder (2003) aponta dois "estilos" ou modelos de taxonomia, que emergiram na literatura, para classificação das indústrias. Um primeiro, centrado na intensidade tecnológica, categorizando os setores em alta e baixa tecnologia, e um segundo, apoiado nos conceitos de regime tecnológico. 
A classificação baseada nos setores tecnológicos foi desenvolvida no âmbito das propostas de indicadores de inovação da Organização para Cooperação e Desenvolvimento Econômico OCDE. Este tipo de classificação está baseado na intensidade da produção tecnológica, refletindo o processo de difusão através dos setores, tendo como referencial a intensidade de gastos em P\&D no setor. Sua versão atual identifica os setores industriais em quatro grupos principais de intensidade tecnológica: alta intensidade tecnológica; média alta intensidade tecnológica; media-baixa intensidade tecnológica; e baixa intensidade tecnológica.

O segundo modelo, conforme acenado, encontra suas premissas no conceito de regime tecnológico (ou paradigma tecnológico), na abordagem neo-schumpeteriana. Sua principal (e pioneira) contribuição está nos trabalhos de Pavitt (1984). É importante destacar, inicialmente, que a taxonomia de Pavitt não refere diretamente à definição de regimes tecnológicos e não considera, conforme Marsili e Verspagen (2001), a base de conhecimento da firma. No entanto, ela pode ser relacionada às condições de oportunidades tecnológicas, ameaça de firmas entrantes de base tecnológica e apropriabilidade. Sua taxonomia distinguiu várias categorias de firmas inovativas baseada nas características estruturais e organização das atividades inovativas. Pavitt (1984) identificou inicialmente três grupos de firmas: (i) baseadas em ciência; (ii) intensivas em produção; (iii) dominadas por fornecedores. Posteriormente, essa taxonomia foi revisada, introduzindo-se outra categoria, a de firmas intensivas em informação. Na taxonomia proposta por Pavitt verifica-se que as características técnicas de base produtiva de cada um dos setores da indústria condicionam seu processo de geração e difusão de inovações (GARCIA 2001).

Outra importante classificação para o estudo de padrões setoriais de inovação, destacada por Pavitt (1984), é a das inovações em cada setor de acordo com o critério dos setores de produção, de uso e de atividade principal da firma inovadora serem ou não o mesmo. São cinco, em termos de categoria, as combinações possíveis:

Categoria 1: o setor produtor, usuário e de atividade principal da firma é o mesmo: por exemplo, uma inovação de processo de uma forma produtora de aço;

Categoria 2: o setor produtor e de atividade principal da firma são o mesmo, mas o setor usuário é diferente: por exemplo, uma firma especializada na produção de máquinas têxteis, projetando uma nova máquina têxtil para uso na indústria têxtil; 
Categoria 3: o setor de atividade principal da firma e usuário da inovação são o mesmo, mas o setor produtor da inovação é diferente: por exemplo, uma firma de construção naval desenvolve uma máquina-ferramenta especial para uso na construção naval;

Categoria 4: o setor produtor e usuário da inovação são o mesmo, mas o setor de atividade principal da firma é diferente: por exemplo, uma firma atuando principalmente em produtos químicos, em geral, desenvolve uma inovação de processo para indústria têxtil;

Categoria 5: o setor produtor da inovação, de uso e de atividade principal da firma são todos diferentes: por exemplo, uma firma atuando principalmente em bens de capital eletrônicos desenvolve e produz uma inovação em equipamentos para serem usados na produção de automóveis.

A taxonomia de Pavitt, bem como a de seus seguidores, baseia-se em indicadores de atividades inovativas no nível da indústria ou setor. A taxonomia baseada na indústria é construída a partir dos conceitos de regime tecnológico, que considera o comportamento inovativo da firma como sendo similar nas atividades de produção. Entretanto, o comportamento inovativo pode ser heterogêneo dentro de um determinado setor em função das diferenças relacionadas ao desempenho (performance), técnicas e estratégias.

De acordo com Kupfer e Rocha (2005), a diversidade intraindústria é considerada tão profunda que as características individuais de cada firma despontam como variável-chave para explicar a dinâmica tecnológica e industrial.

Sendo assim, Archibugi (2001) argumenta que para explicar esta heterogeneidade, as taxonomias baseadas em tecnologia precisam ser desenvolvidas diretamente no nível da firma, antes de agregar tais firmas em um sistema padrão de classificação industrial.

Diversos outros estudos sobre padrões de inovação, apoiados ou não na abordagem de Pavitt, foram realizados nas últimas duas décadas. Dentre os principais destacam-se os trabalhos de Archibugi et al (1991), Malerba e Orsenigo (1996), Marsilli (2001), Evangelista (2000), Peneder (2002), e Raymond et al. (2004).

No contexto brasileiro, alguns estudos e pesquisas sobre o panorama da inovação tecnológica no país têm sido realizados. A Pesquisa Industrial de Inovação Tecnológica - Pintec é a primeira pesquisa mais ampla, referida ao contexto nacional, cuja primeira versão foi realizada em 2000, com base na metodologia da OCDE. Apóia-se em conceitos internacionalmente comparáveis, buscando retratar as atividades inovativas das indústrias brasileiras. 
Em 2005, o Instituto de Pesquisa Econômica Aplicada (IPEA), em convênio com o IBGE, divulgou um amplo estudo sobre as empresas brasileiras e suas estratégias competitivas (DE NEGRI e SALERNO, 2005). O estudo discutiu o impacto da inovação e diferenciação de produtos e suas relações com o crescimento das firmas. Uma abordagem setorial também foi apresentada, com análises das estratégias empresariais por setor de atividade, com o objetivo de aprofundar o entendimento da dinâmica competitiva, que não é necessariamente igual em todos os setores e segmentos da indústria.

Quanto aos estudos voltados para a identificação de regimes tecnológicos intersetoriais, são poucos os desenvolvidos no Brasil. Sbragia et al. (2001) identificaram quatro tipos de empresas inovadoras no país com base na pesquisa ANPEI (Associação Nacional de Pesquisa, Desenvolvimento e Engenharia das Empresas Inovadoras): (I) empresas capacitadas e inovadoras; (II) empresas capacitadas, porém pouco inovadoras; (III) empresas inovadoras, porém pouco capacitadas e; (IV) empresas pouco capacitadas e pouco inovadoras.. Outro trabalho que se destaca é o de Kannebley Jr. et al. (2004) cuja análise exploratória setorial baseou-se nas estatísticas da Pintec. Vale destacar que em ambos os trabalhos, a metodologia utilizada apoia-se em referenciais, com enfoque conceitual distintos daqueles citados acima.

Mais recentemente, Campos e Ruiz (2009), apresentaram um estudo para traçar o perfil setorial da inovação na indústria brasileira, cujo referencial usado é a taxonomia de Pavitt (1984) e a base principal de dados, a da Pintec 2000. O conjunto de variáveis (ou características setoriais abordadas) que definiram o padrão de inovação foram agrupadas em 5 blocos: (I) fontes de inovação; (II) tipos de conhecimento relevantes e as formas de aprendizagem; (III) foco na trajetória tecnológica; (IV) resultados inovativos; (V) variáveis de estrutura e desempenho. O resultado apontou que o padrão verificado no quadro brasileiro é coerente com as proposições da literatura internacional, encaixando-se na taxonomia de Pavitt (1984), com algumas exceções pontuais.

\subsection{Acumulação de capacidades tecnológicas}

\subsubsection{Considerações gerais}

Desde a década de 1970 a literatura sobre tecnologia e desenvolvimento tem enfatizado a aquisição de capacidade tecnológica nos países em desenvolvimento como um determinante crucial da industrialização bem sucedida (Romijn, 1997). De uma maneira simples, a capacitação tecnológica refere-se ao processo de acumulação de capacidades tecnológicas por 
meio dos vários processos subjacentes de aprendizagem, conforme Figueiredo (2004). No entanto, são várias as definições de capacidade tecnológica encontradas na literatura.

A capacidade tecnológica, conforme Lall (1992), requer um esforço interno para o domínio, adaptação e aperfeiçoamento de novas tecnologias. Para os países em desenvolvimento, não é uma tarefa simples desenvolver habilidades, experiências e esforços que permitem que as empresas de um país adquiram, utilizem e adaptem, aperfeiçoem e criem tecnologias com eficiência (LALL, 2005).

A maquinaria está disponível igualmente para todos os países, no entanto, os elementos nãoincorporados da tecnologia não podem ser adquiridos ou transferidos como produtos físicos. O conhecimento tecnológico é difícil de se localizar, assim como sua transferência não pode ser incorporada nos equipamentos, instruções, patentes, projetos ou esquemas. Os conhecimentos incorporados só poderão ser usados da melhor maneira possível se forem complementados por diversos elementos tácitos que terão de ser desenvolvidos localmente. Em outros termos, há a necessidade de desenvolvimento de um aprendizado local. A transferência necessariamente requer aprendizagem porque as tecnologias são de caráter tácito, e seus princípios subjacentes não são sempre claramente entendidos (LALL, 1992; 2005).

Para Bell e Pavitt $(1993 ; 1995)$ a capacidade tecnológica consiste nos recursos necessários para gerar e gerir as mudanças técnicas, e inclui, em especial, habilidades, conhecimentos, experiências e estrutura institucional. Tais recursos, uma vez acumulados, são incorporados às pessoas e aos sistemas organizacionais. Nesse sentido, pode-se afirmar, conforme Figueiredo (2004; 2009), que a capacidade tecnológica de uma empresa (ou de um setor industrial) está armazenada e acumulada, em pelo menos quatro componentes, a saber:

(i) Sistemas técnicos físicos: Referem-se à maquinaria e equipamentos, sistemas baseados em tecnologia de informação, software em geral e plantas de manufatura;

(ii) Pessoas (conhecimento e qualificação): referem-se ao conhecimento tácito, às experiências e habilidades de gerentes, engenheiros, técnicos e operadores que são adquiridos ao longo do tempo, mas que também abrangem sua qualificação formal.

(iii) Sistema (tecido) organizacional: refere-se ao conhecimento acumulado nas rotinas organizacionais e gerenciais das empresas, nos procedimentos, nas instruções, na documentação, na implantação de técnicas de gestão (total quality management -TQM; material requeriment planning - MRP, just in time - JIT, etc.) 
(iv) Produtos e serviços: referem-se à parte mais visível da capacidade tecnológica e refletem o conhecimento tácito das pessoas e da organização e dos seus sistemas físicos e organizacionais. Por exemplo, nas atividades de desenho, desenvolvimento de prototipagem, teste, produção, e na parte de comercialização de produto e serviços, estão refletidos os outros três componentes da capacidade tecnológica.

A capacidade tecnológica será então a capacidade das empresas para criar, adaptar, gerir e gerar esses quatros componentes e a interação entre eles. Uma representação na Figura 2 mostra as quatro dimensões.

\section{Figura 2:Dimensões da capacidade tecnológica}

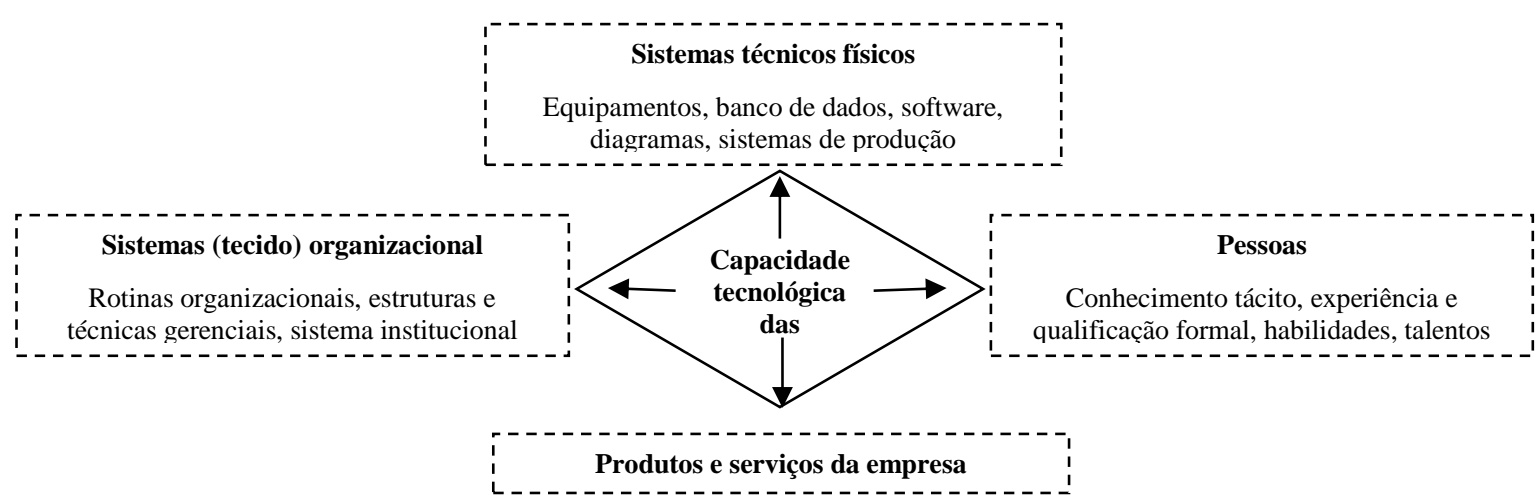

Fonte: Figueiredo (2004; 2005)

É importante ressaltar que entre as quatro dimensões existe um grau de importância e prioridade, em se tratando de economias em desenvolvimento. As empresas nesses países normalmente iniciam seus negócios a partir de tecnologias importadas de países de alto desenvolvimento industrial. Conforme destacado por Lall (2000), uma vez que a tecnologia é importada, o seu uso eficiente requer a criação de novos conhecimentos e habilidades para dominar os seus elementos tácitos. Por essa razão, os componentes recursos humanos e sistemas organizacionais e gerenciais são mais exigidos e tem importância maior do que sistemas técnico-físicos e produtos e serviços. Os sistemas técnico-físicos (máquinas, equipamentos, software) podem ser facilmente adquiridos no mercado global, enquanto que os recursos humanos e o sistema organizacional (em função da especificidade das rotinas organizacionais) dificilmente são comercializáveis. Por essa razão tais dimensões precisam ser desenvolvidas internamente, já que é a partir que as tecnologias adquiridas de outras empresas e países serão assimiladas, absorvidas, e posteriormente, alteradas, aprimoradas e até transformadas em novas tecnologias (FIGUEIREDO, 2009). 
As capacidades tecnológicas acumuladas podem ser subdivididas em capacidade de produção/operação, e em capacidades tecnológicas inovadoras, conforme Bell e Pavitt (1993), (Figura 3). As primeiras incorporam recursos para a produção de bens industriais a determinados níveis de eficiência, por meio de equipamentos (tecnologia incorporada), habilidades de operação no trabalho (operando e gerenciando know-how e experiência), métodos organizacionais, entre outros.

As capacidades tecnológicas, por sua vez, consistem nos recursos necessários para gerar e gerenciar mudanças técnicas, e incluem habilidades, conhecimento e experiências e estruturas institucionais.

Figura 3:Acumulação tecnológica: conceitos e termos básicos

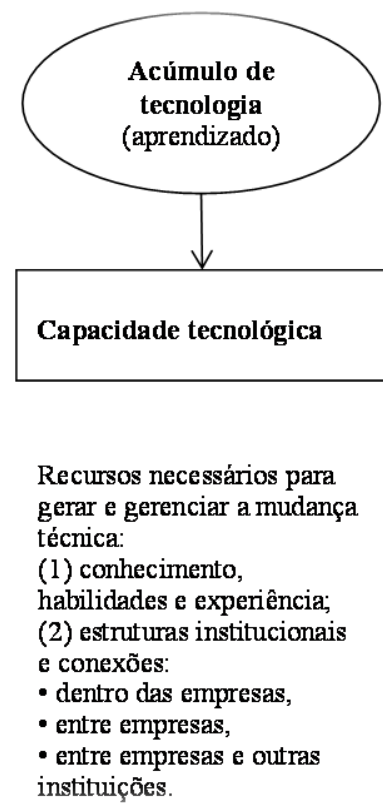

Acumulaçāo de Capacidade Tecnológica

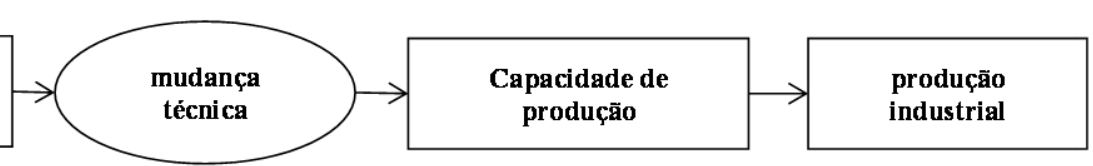

(a) tecnologia incorporada em novos produtos $\mathrm{e} / \mathrm{ou}$ novas plantas através de grandes investimentos (b) adaptação incremental e melhoria da capacidade de produção existente

$$
\begin{aligned}
& \text { Componentes do sistemas } \\
& \text { de produção dados: } \\
& \text { - capital fixo } \\
& \text { - habilidades de operação } \\
& \text { no trabalho e conhecimento } \\
& \text { - especificações do } \\
& \text { produto/design } \\
& \text { - especificações de entrada } \\
& \text { - organização e } \\
& \text { procedimentos da produção }
\end{aligned}
$$

\section{Fonte: Bell e Pavitt (1993)}

De acordo com Figueiredo (2009), a distinção entre os tipos de capacidades (produção/operação e de inovação) é importante, em especial para empresas de países em desenvolvimento, pois uma empresa pode apresentar uma capacidade tecnológica avançada de produção e nenhuma ou limitada capacidade tecnológica para inovação. A acumulação de ambos os tipos de capacidade tecnológica poderá gerar um aperfeiçoamento de desempenho ambiental, operacional e financeira, ou seja, liderança de mercado, aumento de produtividade, melhoria de qualidade de processos e produtos, redução de custos, etc. (Figura 4) . 
Figura 4: Capacidade tecnológica e seus impactos

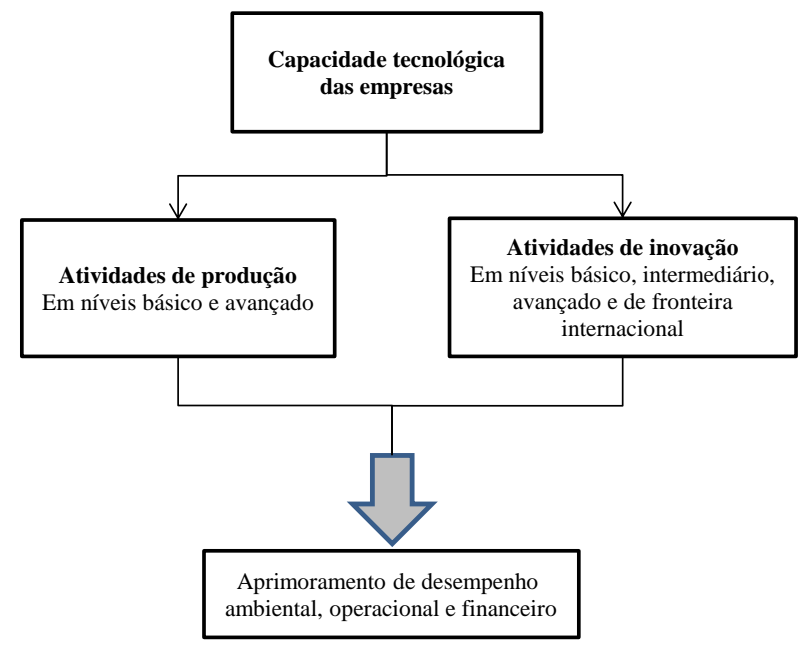

Fonte: Figueiredo (2009)

Em países periféricos ou economias emergentes, uma das principais características presentes, do ponto de vista tecnológico, é o uso de tecnologias desenvolvidas em países centrais ou industrialmente desenvolvidos. Quando, em alguns países, há certo domínio e desenvolvimento de determinadas tecnologias, normalmente são para aquelas de menor conteúdo. O Brasil, a exemplo, apesar de ter construído, já na década de 1950, uma base no setor de bens de capital, não desenvolveu áreas mais complexas e especializadas como instrumentação, ou em setores baseados em ciências, como o eletrônico. Tipicamente, as economias da América Latina começaram produzindo máquinas mais simples e permaneceram limitadas na produção de máquinas mais complexas. Como consequência, raramente essas economias foram capazes de competir internacionalmente (BELL e PAVITT, 1995).

A aproximação da fronteira tecnológica internacional requer das empresas um engajamento nos processos de aprendizagem para a construção e acúmulo de capacidade tecnológica, conforme destacado por Figueiredo (2004). De acordo com Zhou e Wu (2010), quando uma empresa constrói a sua capacidade tecnológica, investe recursos substanciais em pesquisa e desenvolvimento (P\&D), que envolve a descoberta de novos produtos, o acúmulo de conhecimento, bem como a formação de pessoal técnico. A acumulação de conhecimento tecnológico, por sua vez, aumenta a capacidade da empresa para avaliar e utilizar novas tecnologias. Como resultado desse processo, a empresa pode identificar rapidamente uma nova tendência tecnológica e se envolver em inovações de produtos que podem ir além da atual fronteira tecnológica. Portanto, pode-se observar uma relação estreita entre o acúmulo de capacidades de inovação tecnológica e o processo exploratório da inovação. É importante 
destacar que o acúmulo de capacidade tecnológica não é um processo imediato, envolve uma sequência evolutiva e cumulativa, que se inicia nos estágios mais simples, desenvolvendo-se para os mais complexos.

\subsubsection{Principais estudos empíricos e métricas sobre capacidade tecnológica}

Conforme Bell (2007), várias abordagens têm sido utilizadas ao longo das últimas três décadas ou mais para classificar vários tipos e níveis de "capacidade tecnológica" nos países em desenvolvimento, sejam como base para a análise acadêmica, sejam como base para formulação de políticas. As abordagens têm tratado e explorado questões em nível macro (Archibugi e Coco, 2005), e em nível micro. Esta última concentra-se nas capacidades tecnológicas em nível de empresas, que utilizam, operam, criam e modificam a tecnologia. Vale destacar que o contexto de análise tem predominantemente a indústria como objeto de estudo, buscando classificar e diferenciar as capacidades.

É importante ressaltar, também, que as abordagens sobre a capacidade tecnológica inicialmente centravam-se, fundamentalmente, nos recursos internos das empresas. Atualmente, há um reconhecimento de que os recursos ultrapassam o foco interno das empresas e abrangem, também, conhecimentos centrados nas interações entre empresas e entre as empresas e outras organizações (BELL, 2007).

Outro aspecto importante a ser ressaltado é a ênfase dada nos componentes de capacidade humana e organizacional em contraponto às formas de tecnologia incorporada. Em outros termos, entende-se capacidade como sendo sobre as capacidades humanas e organizacionais que as empresas têm para realizar ações com relação à tecnologia que eles usam (por exemplo, para operá-la ou para criá-la e alterá-la), e não sobre as formas incorporadas da tecnologia como sistemas de produção e instalações.

Conforme apresentado em Bell (2007), uma das primeiras classificações de capacidade tecnológica com foco em países em desenvolvimento foi realizada, no início da década de 1970, por Hayami e Ruttan (1971). Nessa perspectiva consideram-se as diferenças nos níveis de capacidade e a transferência internacional de tecnologia (TIT). Em decorrência disso, a ênfase recai mais na distinção entre as três fases de transferência internacional de tecnologia para países em desenvolvimento, do que na classificação das capacidades locais. As três fases de transferência internacional de tecnologia, assim chamadas, são: transferência de material; transferência de projeto (planta); e transferência de capacidade. Presume-se nestas fases que há uma trajetória de progresso a partir do uso das tecnologias importadas, permitindo 
adaptações e aperfeiçoamentos. No entanto, a trajetória de progresso, esperada nos países em desenvolvimento, não ocorreu. A trajetória de aprendizagem tecnológica não passou além do nível de adaptação e aperfeiçoamento de protótipos.

No final dos anos 1970 e início de 1980, uma rede de estudiosos latino-americanos fizeram os primeiros estudos sistemáticos de mudança tecnológica e de inovação nas empresas industriais de países em desenvolvimento. Katz (1987) sintetizou esses estudos destacando (a) a importância de várias funções-chave tecnológicas nas empresas, juntamente com (b) as ideias sobre as sequências em que as empresas acumulam capacidades nestas áreas funcionais.

Os estudos revelaram que muitas empresas foram além da simples operação da tecnologia adquirida. Houve um avanço no sentido de várias adaptações e melhorias. Em outros termos as empresas foram empresas criadoras de conhecimento e usuárias de conhecimento. Entretanto, deve-se ressaltar que tais colocações não alcançaram uma discussão sobre $P \& D$ nas empresas. Por outro lado, o comportamento tecnológico das empresas industriais possibilitou identificar esta atividade de criação de conhecimento enraizada em atividades internas (ou instaladas) de engenharia. Em especial, foram identificadas três funções principais dentro desse conjunto de atividades:

- Projeto e especificações do produto;

- Engenharia de processos; e

- Engenharia industrial /planejamento da produção

Há o reconhecimento que os papeis e a importância relativa dessas funções diferem entre os tipos de indústria, em especial entre processo contínuo de fabricação e não-contínuo. Verificase também uma sequencia típica de passos de desenvolvimento de capacidades nas áreas funcionais, com o projeto de produto surgindo inicialmente na empresa, seguido pela engenharia de processos e atividades de planejamento de produção.

Entretanto, esta sequência foi vista simplesmente como algo que envolve mudanças entre diferentes funções e não implica qualquer progresso entre diferentes níveis de capacidade. Por outro lado, deve-se considerar como importante a mudança dentro dessas áreas, sugerindo, por exemplo, que o projeto de produto pode avançar de um estágio incipiente e informal para outro formalmente organizado, empregando-se mais capital humano avançado.

Ainda na década de 1980, Dahlman e Westphal (1982), deram ênfase a um conceito mais amplo de capacidade, que vai além do uso e da produção, a capacidade de inovação. Tal 
trajetória foi abordada em termos de aumento do domínio tecnológico. Partiam da ideia de diferentes níveis de capacidade para diferentes estágios no ciclo de vida dos projetos industriais.

Ao longo dos anos da década de 1990, destacam-se os trabalhos de Amsden (2001) e Lall (1987; 1992). Amsden (2001) fez uso de uma estrutura similar a de Dahlman e Westphal, em que centrava em diferentes estágios no ciclo de vida dos projetos industriais. Tal como acontece com Dahlman e Westphal (1982), Amsden define essas etapas dentro de uma perspectiva dinâmica que vê as empresas "construindo" as capacidades enquanto se movem através do tempo entre as categorias: da capacidades de produção por meio de capacidade de execução de projetos à capacidade de inovação. Mas, novamente como em Dahlman e Westphal, tal progresso através dos diferentes níveis também ocorre dentro das categorias. Embora menos evidente no caso das capacidades produção e execução de projetos (investimento), são claras as capacidades, no que se refere à inovação. Dentro desta categoria, as empresas podem aprofundar suas capacidades, passando de desenvolvimento avançado para pesquisa básica e ciência pura.

Quanto aos trabalhos de Lall $(1987 ; 1992)$ desenvolveu-se, inicialmente, uma estrutura que melhor distinguiu as funções e níveis de capacidade. Em sua perspectiva enfatizou a importância de distinguir as capacidades de funções tecnológicas, tais como engenharia de processos, engenharia de produto e execução de projeto. É notável, no que se refere às atividades tecnológicas, a importância dada às várias formas de engenharia como funções fundamentais para a adaptação e melhoria da tecnologia. Como resultado, elaborou também um conjunto de diferenças nas capacidades de cada um desses tipos de função (Lall, 1987). Para a função de preparação de projeto, destacam-se as atividades de identificação de projeto sustentável, estudos de viabilidade, especificação de escala de produção, negociação para transferência de tecnologia, etc. Para a função de engenharia de processo tem-se atividade de depuração da nova planta, desenvolvimento formal de novos processos, melhoria de processos, etc. No que se refere à engenharia de produto, tem-se a adaptação do produto ao mercado local, melhoria do projeto de produto, pesquisa básica, desenvolvimento de novos produtos próprios, etc.

Em um trabalho posterior (Lall, 1992), estas dimensões de capacidade foram separadas de maneira mais clara, conforme mostrado no Quadro 2, a seguir. 
Quadro 2: Matriz ilustrativa de capacidades tecnológicas

\begin{tabular}{|c|c|c|c|c|c|c|c|c|}
\hline \multicolumn{5}{|c|}{ INVESTIMENTO } & \multicolumn{4}{|c|}{ PRODUÇÃO } \\
\hline & & & $\begin{array}{l}\text { PRÉ- } \\
\text { INVESTIMEN } \\
\text { TO } \\
\end{array}$ & $\begin{array}{c}\text { EXECUÇÃO DE } \\
\text { PROJETO }\end{array}$ & $\begin{array}{l}\text { ENGENHARIA } \\
\text { DE PROCESSO }\end{array}$ & $\begin{array}{c}\text { ENGENHARI } \\
\text { A DE } \\
\text { PRODUTO } \\
\end{array}$ & $\begin{array}{c}\text { ENGENHARI } \\
\text { A } \\
\text { INDUSTRIAL } \\
\end{array}$ & $\begin{array}{c}\text { CONEXÕES } \\
\text { NA } \\
\text { ECONOMIA }\end{array}$ \\
\hline \multirow{3}{*}{ 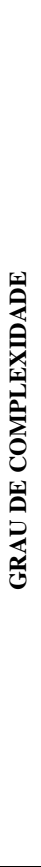 } & 造 & $\begin{array}{l}\text { ROTINEIRO } \\
\text { SIMPLES } \\
\text { (baseado na } \\
\text { experiência) }\end{array}$ & $\begin{array}{l}\text { Pré-viabilidade } \\
\text { e estudos de } \\
\text { viabilidade, } \\
\text { escolha de } \\
\text { local, programa } \\
\text { de } \\
\text { investimento. }\end{array}$ & $\begin{array}{l}\text { Construção civil, } \\
\text { serviços } \\
\text { auxiliares, } \\
\text { Montagem de } \\
\text { equipamentos. }\end{array}$ & $\begin{array}{l}\text { Depuração, } \\
\text { controle de } \\
\text { qualidade, } \\
\text { manutenção } \\
\text { preventiva, etc. }\end{array}$ & $\begin{array}{l}\text { Assimilação de } \\
\text { projeto de } \\
\text { produto, menor } \\
\text { adaptação para } \\
\text { necessidades do } \\
\text { mercado. }\end{array}$ & $\begin{array}{l}\text { Fluxo de } \\
\text { trabalho, } \\
\text { programações, } \\
\text { estudo de } \\
\text { tempos e } \\
\text { movimentos, } \\
\text { controle de } \\
\text { inventários. }\end{array}$ & $\begin{array}{l}\text { Aquisição local } \\
\text { de bens e } \\
\text { serviços, troca } \\
\text { de informações } \\
\text { com } \\
\text { fornecedores }\end{array}$ \\
\hline & 产 & $\begin{array}{l}\text { ADAPTATIVO } \\
\text { DUPLICATIVO } \\
\text { (baseado em } \\
\text { busca) }\end{array}$ & $\begin{array}{l}\text { Busca de fontes } \\
\text { de tecnologia. } \\
\text { Negociação de } \\
\text { contratos. } \\
\text { Termos de } \\
\text { negociação } \\
\text { adequados. } \\
\text { Sistemas de } \\
\text { informação. }\end{array}$ & $\begin{array}{l}\text { Aquisição de } \\
\text { equipamentos, } \\
\text { Engenharia } \\
\text { detalhada, } \\
\text { recrutamento e } \\
\text { treinamento de } \\
\text { pessoal } \\
\text { qualificado. }\end{array}$ & $\begin{array}{l}\text { Adaptação de } \\
\text { processo e } \\
\text { redução de custos, } \\
\text { licenciamento de } \\
\text { novas tecnologias. }\end{array}$ & $\begin{array}{l}\text { Melhoria da } \\
\text { qualidade do } \\
\text { produto, } \\
\text { licenciamento e } \\
\text { assimilação de } \\
\text { novas } \\
\text { tecnologias de } \\
\text { produtos } \\
\text { importados. }\end{array}$ & $\begin{array}{l}\text { Monitoramento } \\
\text { da } \\
\text { produtividade, } \\
\text { melhoria de } \\
\text { coordenação. }\end{array}$ & $\begin{array}{l}\text { Transferência } \\
\text { de tecnologia } \\
\text { dos } \\
\text { fornecedores } \\
\text { locais, projeto } \\
\text { coordenado, } \\
\text { conexões } \\
\text { ciência e } \\
\text { tecnologia } \\
\end{array}$ \\
\hline & 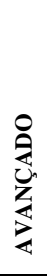 & $\begin{array}{l}\text { INOVATIVO } \\
\text { ARRISCADO } \\
\text { (baseado em } \\
\text { pesquisa) }\end{array}$ & & $\begin{array}{l}\text { Projeto básico de } \\
\text { processo, } \\
\text { Projeto de } \\
\text { equipamento e } \\
\text { suprimento. }\end{array}$ & $\begin{array}{l}\text { Inovação de } \\
\text { processos “in } \\
\text { house”, pesquisa } \\
\text { básica. }\end{array}$ & $\begin{array}{l}\text { Inovação de } \\
\text { produtos "in } \\
\text { house", } \\
\text { pesquisa básica. }\end{array}$ & & $\begin{array}{l}\text { Capacidade de } \\
\text { mudança, } \\
\text { cooperação em } \\
\mathrm{P} \& \mathrm{D} \text {, } \\
\text { licenciamento } \\
\text { de tecnologia } \\
\text { própria para } \\
\text { outros. }\end{array}$ \\
\hline
\end{tabular}

Fonte: Lall (1992)

Outro trabalho importante que se destaca é o de Bell e Pavitt (1995). Essa perspectiva apresentou alguma mudança em relação ao trabalho de Lall (1992). Em especial, foi considerado como importante a distinção entre a capacidade para imitar/usar/operar a tecnologia e a capacidade para mudá-la/criá-la. Nesse sentido, introduziu-se a capacidade básica de produção, em relação à estrutura apresentada por Lall.

Foram também incorporadas várias pequenas adaptações, tais como rearranjo de algumas categorias funcionais, como, por exemplo, a importância de capacidades de facilidade de uso para tomar decisões e exercer o controle sobre as principais características dos projetos de investimento. Manteve-se também a distinção entre as fases de investimento e produção do ciclo do projeto.

O Quadro 3 apresenta o modelo de Bell e Pavitt com tais características. 
Quadro 3: Capacidade tecnológica industrial: um modelo ilustrativo

\begin{tabular}{|c|c|c|c|c|c|c|}
\hline & \multicolumn{4}{|c|}{ Atividades Primárias } & \multirow{2}{*}{\multicolumn{2}{|c|}{ Atividades de suporte }} \\
\hline & \multicolumn{2}{|c|}{ Investimentos } & \multicolumn{2}{|c|}{ Produção } & & \\
\hline & $\begin{array}{l}\text { Facilitar a tomada de } \\
\text { decisão e o controle }\end{array}$ & $\begin{array}{l}\text { Preparação do projeto e } \\
\text { implementação }\end{array}$ & $\begin{array}{l}\text { Organização do } \\
\text { processo e } \\
\text { produção }\end{array}$ & $\begin{array}{l}\text { Foco no } \\
\text { produto }\end{array}$ & $\begin{array}{c}\text { Desenvolvimento } \\
\text { de vínculos }\end{array}$ & $\begin{array}{c}\text { Fornecimento } \\
\text { de bens de } \\
\text { capital }\end{array}$ \\
\hline $\begin{array}{l}\text { Capacidades de } \\
\text { produção básica } \\
\text { Capacidades de } \\
\text { utilizar técnicas de } \\
\text { produção existente }\end{array}$ & $\begin{array}{l}\text { Envolvimento do } \\
\text { contratante principal } \\
\text { Garantia de desembolso } \\
\text { dos recursos financeiros. } \\
\text { Oficialização na } \\
\text { cerimônia de abertura. }\end{array}$ & $\begin{array}{l}\text { Elaboração do esboço } \\
\text { inicial do projeto. } \\
\text { Construção de obras civis } \\
\text { básicas, elevação simples } \\
\text { da fábrica. }\end{array}$ & $\begin{array}{l}\text { Operação rotineira } \\
\text { e manutenção } \\
\text { básica das } \\
\text { instalações } \\
\text { fornecidas. } \\
\text { Melhoria na } \\
\text { eficiência a partir } \\
\text { da experiência em } \\
\text { tarefas existentes. }\end{array}$ & $\begin{array}{l}\text { Replicação de } \\
\text { especificações } \\
\text { e desenhos } \\
\text { fixos. } \\
\text { Direcionando } \\
\text { o controle de } \\
\text { qualidade para } \\
\text { manutenção } \\
\text { de padrões e } \\
\text { especificações } \\
\text { existentes }\end{array}$ & $\begin{array}{l}\text { Contratos de } \\
\text { insumos } \\
\text { disponíveis a } \\
\text { partir de } \\
\text { fornecedores } \\
\text { existentes. Venda } \\
\text { de produtos para } \\
\text { clientes existentes } \\
\text { e novos. }\end{array}$ & $\begin{array}{l}\text { Replicação } \\
\text { de itens } \\
\text { imutáveis de } \\
\text { instalações } \\
\text { e máquinas }\end{array}$ \\
\hline \multicolumn{7}{|c|}{ CAPACACIDADES TECNOLÓGICAS (CAPACIDADES PARA GERAR E GERENCIAR MUDANÇA TÉCNICA) } \\
\hline BÁSICO & $\begin{array}{l}\text { Monitoramento ativo do } \\
\text { controle de estudos de } \\
\text { viabilidade, escolha de } \\
\text { tecnologia e } \\
\text { agendamento de projetos }\end{array}$ & $\begin{array}{l}\text { Estudos de viabilidade. } \\
\text { Esboço de planejamento. } \\
\text { Padrão de aquisição de } \\
\text { equipamentos. Auxiliares } \\
\text { simples de engenharia. }\end{array}$ & $\begin{array}{l}\text { Comissionamento } \\
\text { e depuração. } \\
\text { Layout } \\
\text { melhorado, } \\
\text { agendamento e } \\
\text { manutenção. } \\
\text { Adaptação } \\
\text { mínima.. }\end{array}$ & $\begin{array}{l}\text { Adaptação } \\
\text { mínima ás } \\
\text { necessidades } \\
\text { de mercado e } \\
\text { melhoria } \\
\text { Incremental } \\
\text { na qualidade } \\
\text { do produto. }\end{array}$ & $\begin{array}{l}\text { Busca e absorção } \\
\text { de novas } \\
\text { informações de } \\
\text { fornecedores, } \\
\text { clientes e } \\
\text { instituições } \\
\text { locais. }\end{array}$ & $\begin{array}{l}\text { Cópia de } \\
\text { novos tipos de } \\
\text { fábricas e } \\
\text { maquinários. } \\
\text { Adaptação } \\
\text { simples de } \\
\text { desenhos e } \\
\text { especificações } \\
\text { existentes.. } \\
\end{array}$ \\
\hline INTERMEDIÁRIO & $\begin{array}{l}\text { Busca, avaliação e } \\
\text { seleção de } \\
\text { tecnologias/fontes, } \\
\text { propostas/negociações. } \\
\text { gerenciamento de } \\
\text { projetos global. }\end{array}$ & $\begin{array}{l}\text { Engenharia detalhada. } \\
\text { Aquisição de fábricas. } \\
\text { Avaliação de ambiente. } \\
\text { gerenciamento e } \\
\text { agendamento de projetos. } \\
\text { comissionamento. } \\
\text { Treinamento/recrutamento } \\
\text {. }\end{array}$ & $\begin{array}{l}\text { Melhoria de } \\
\text { processo. } \\
\text { Licenciamento } \\
\text { de novas } \\
\text { tecnologias- } \\
\text { introdução de } \\
\text { mudanças } \\
\text { organizacionais. }\end{array}$ & $\begin{array}{l}\text { Licenciamento } \\
\text { de tecnologias } \\
\text { de novos } \\
\text { produtos e/ou } \\
\text { engenharia } \\
\text { reversa. } \\
\text { Desenho } \\
\text { incremental } \\
\text { de novos } \\
\text { produtos. }\end{array}$ & $\begin{array}{l}\text { Transferência de } \\
\text { tecnologia para } \\
\text { fornecedores e } \\
\text { clientes para } \\
\text { melhorar } \\
\text { eficiência, } \\
\text { qualidade e } \\
\text { fornecimento } \\
\text { local. }\end{array}$ & $\begin{array}{l}\text { Inovação } \\
\text { incremental de } \\
\text { engenharia } \\
\text { reversa e } \\
\text { desenho } \\
\text { original de } \\
\text { fábricas e } \\
\text { maquinário. }\end{array}$ \\
\hline AVANÇADO & $\begin{array}{l}\text { Desenvolvimento de } \\
\text { novos sistemas de } \\
\text { produção e componentes. }\end{array}$ & $\begin{array}{l}\text { Desenho básico de } \\
\text { processo e P\&D } \\
\text { relacionado. }\end{array}$ & $\begin{array}{l}\text { Inovação de } \\
\text { processo e } \mathrm{P} \& \mathrm{D} \\
\text { relacionado. } \\
\text { Inovação radical } \\
\text { na organização. } \\
\end{array}$ & $\begin{array}{l}\text { Inovação de } \\
\text { produto e } \\
\text { P\&D } \\
\text { relacionado. }\end{array}$ & $\begin{array}{l}\text { Colaboração no } \\
\text { desenvolvimento } \\
\text { de tecnologia. }\end{array}$ & $\begin{array}{l}\text { P\&D para } \\
\text { especificações } \\
\text { e desenho de } \\
\text { novas fábricas } \\
\text { e maquinário. }\end{array}$ \\
\hline
\end{tabular}

Fonte: Bell e Pavitt (1995)

A partir das estruturas construídas por Lall, Bell e Pavitt, outros estudos foram desenvolvidos, com destaque para Ariffin (2000), Dutrenit (2000) e Figueiredo (2003), apoiando-se nas principais características dessas contribuições, como segue:

- Distinção entre diferentes dimensões de capacidade, em particular entre funções e níveis;

- Diferenciação mais detalhada entre os níveis mudança/criação e inovação tecnológica;

- Diferenciação dos níveis entre (a) imitação/utilização/operação da tecnologia e (b) mudança (evolução) /criação/inovação tecnológica.

Ariffin (2000) reduziu o número de funções e não fez uso da dimensão estágios. Dutrenit (2000) simplificou a estrutura, destacando o conceito-chave da transição na construção de capacidade. 
Figueiredo (2003), por sua vez, elaborou em maiores detalhes a estrutura proposta por Lall (1992), Bell e Pavitt (1995), desenvolvendo, em empresas brasileiras, uma análise detalhada de mudanças nos recursos organizacionais, a fim de examinar a relação entre o progresso das firmas, acima de 40 anos, através de diferentes níveis de capacidade e suas abordagens para o gerenciamento da aquisição e absorção da tecnologia.

Tal estudo resultou em um modelo com sete diferentes níveis de capacidade, avaliados através de um conjunto semelhante de funções tecnológicas, conforme mostrada no Quadro 4. Embora o modelo apresentado tenha aplicação para a indústria do aço, adaptações podem ser feitas para estudos de desenvolvimento tecnológico em outros setores.

O modelo consiste em sete níveis de capacidade tecnológica em quatro funções: (i) investimentos; (ii) processos e organização da produção; (iii) produto; e (iv) equipamento.

Além disso, o modelo permite identificar e medir capacitação tecnológica com base em atividades que a empresa é capaz de fazer ao longo de sua existência. É possível fazer a distinção entre capacidades rotineiras, que são as capacidades para usar ou operar certa tecnologia, e capacidades inovadoras, que se referem às capacidades para adaptar e/ou desenvolver novos processos de produção, sistemas organizacionais, produtos, equipamentos e projetos de Engenharia.

Em outros termos, é a capacidade para gerar e gerir a inovação tecnológica (FIGUEIREDO, 2004). Tal distinção e a configuração do modelo ampliado são importantes, pois levam consigo características de empresas que operam em uma economia em desenvolvimento e, portanto, é mais adequado do que aquele adotado na literatura de empresas que operam na fronteira tecnológica internacional.

Embora a indústria de bens de capital no Brasil tenha sido explorada em alguns estudos, com o objetivo de propor estratégias de desenvolvimento industrial, tecnológico e setorial, tais como em Jorge (1993), Vermulm (1995) e Valença (2001), conforme apontado por Tacla e Figueiredo (2003), há uma escassez de estudo intraempresarial mais detalhado, que considere as empresas em seus mais diversos estágios de acúmulo de capacidade tecnológica. 
Quadro 4: Capacidades tecnológicas em empresas de economias emergentes

\begin{tabular}{|c|c|c|c|c|c|}
\hline \multirow{3}{*}{$\begin{array}{l}\text { Níveis de } \\
\text { Competência } \\
\text { tecnológica }\end{array}$} & \multicolumn{5}{|c|}{ Funções Tecnológicas e Atividades Relacionadas } \\
\hline & \multicolumn{2}{|c|}{ Investimentos } & \multirow{2}{*}{$\begin{array}{c}\text { Processos e } \\
\text { organização da } \\
\text { produção }\end{array}$} & \multirow[b]{2}{*}{ Produtos } & \multirow[b]{2}{*}{ Equipamentos } \\
\hline & $\begin{array}{l}\text { Decisão e controle } \\
\text { sobre a planta }\end{array}$ & $\begin{array}{c}\text { Engenharia de } \\
\text { projetos }\end{array}$ & & & \\
\hline & \multicolumn{5}{|c|}{ ROTINA } \\
\hline $\begin{array}{c}\text { (1) } \\
\text { Básico }\end{array}$ & $\begin{array}{l}\text { Decisão sobre } \\
\text { localização da } \\
\text { planta. Termos de } \\
\text { referência. }\end{array}$ & $\begin{array}{l}\text { Preparação inicial de } \\
\text { projeto. Sincroniza- } \\
\text { ção de trabalhos de } \\
\text { construção civil e } \\
\text { instalações. }\end{array}$ & $\begin{array}{l}\text { Coordenação de } \\
\text { rotina na planta. } \\
\text { Absorção da } \\
\text { capacidade da planto. } \\
\text { PCP e CQ básicos }\end{array}$ & $\begin{array}{l}\text { Replicação de aços } \\
\text { seguindo especifica- } \\
\text { ções amplamente } \\
\text { aceitas. CQ de rotina. } \\
\text { Fornecimento a mer- } \\
\text { cados de exportação }\end{array}$ & $\begin{array}{l}\text { Reposição de rotina } \\
\text { de componentes de } \\
\text { equipamento. Parti- } \\
\text { cipação em instala- } \\
\text { ções e testes de } \\
\text { performance }\end{array}$ \\
\hline \multirow[t]{2}{*}{$\begin{array}{c}(2) \\
\text { Renovado }\end{array}$} & $\begin{array}{l}\text { Monitoramento ativo } \\
\text { de rotina de unidades } \\
\text { existentes na planta. }\end{array}$ & $\begin{array}{l}\text { Serviços rotineiros de } \\
\text { engenharia no planto } \\
\text { nova e/ou existente. }\end{array}$ & $\begin{array}{l}\text { Estabilidade do AF e } \\
\text { aciaria. Coordenação } \\
\text { aprimorada da planta. } \\
\text { Obtenção de certifi- } \\
\text { cação (ex, ISO 9002, } \\
\text { QS 9000) }\end{array}$ & $\begin{array}{l}\text { Replicação aprimorada } \\
\text { de especificações de } \\
\text { ocos dados ou próprios. } \\
\text { Obtenção de } \\
\text { certificação } \\
\text { Internacional para CQ } \\
\text { de rotina. }\end{array}$ & $\begin{array}{l}\text { Manufatura e reposi- } \\
\text { ção de componentes } \\
\text { (ex. cilindros) sob } \\
\text { certificação interna- } \\
\text { cional (ISO 9002) }\end{array}$ \\
\hline & \multicolumn{5}{|c|}{ INOVADORAS } \\
\hline $\begin{array}{c}\text { (3) } \\
\text { Extrabásico }\end{array}$ & $\begin{array}{l}\text { Envolvimento ativo } \\
\text { em fontes de } \\
\text { financiamento de } \\
\text { tecnologia. }\end{array}$ & $\begin{array}{l}\text { Planejamento de } \\
\text { projeto. Estudos de } \\
\text { viabilidade } \\
\text { tecnicamente } \\
\text { assistidos, para } \\
\text { grandes expansões. }\end{array}$ & $\begin{array}{l}\text { Pequenas adaptações } \\
\text { e intermitentes em } \\
\text { processos, eliminação } \\
\text { de gargalos, e alongo } \\
\text { mento de capacidade. }\end{array}$ & $\begin{array}{l}\text { Pequenas adaptações } \\
\text { em especificações } \\
\text { dadas. Criação de } \\
\text { especificações próprias } \\
\text { para aços (dimensão, } \\
\text { forma, propriedades } \\
\text { mecânicas). }\end{array}$ & $\begin{array}{l}\text { Adaptações pequenas } \\
\text { em equipamentos para } \\
\text { ajustá-los a matérias } \\
\text { primas locais. } \\
\text { Manutenção break- } \\
\text { down. }\end{array}$ \\
\hline $\begin{array}{c}\text { (4) } \\
\text { Pré- } \\
\text { Intermediário }\end{array}$ & $\begin{array}{l}\text { Monitora mento } \\
\text { parcial e controle de: } \\
\text { estudos de } \\
\text { viabilidade de } \\
\text { expansão, busca, } \\
\text { avalição, e seleção } \\
\text { de tecnologia e } \\
\text { fornecedores. }\end{array}$ & $\begin{array}{l}\text { Engenharia de } \\
\text { instalações. Expan- } \\
\text { sões tecnicamente } \\
\text { assistidas. Engenharia } \\
\text { de detalhamento. }\end{array}$ & $\begin{array}{l}\text { Alongamentos siste- } \\
\text { máticos de capaci- } \\
\text { dade. Manipulação de } \\
\text { parâmetros chove de } \\
\text { processo. Novas } \\
\text { técnicas } \\
\text { organizacionais } \\
\text { (TQC/M, ZD, JTT). }\end{array}$ & $\begin{array}{l}\text { Aprimoramentos siste- } \\
\text { máticos em especifi- } \\
\text { cações dadas. } \\
\text { "Engenharia reversa" } \\
\text { sistemática. } \\
\text { Desenvolvimento de } \\
\text { especificações próprias. }\end{array}$ & $\begin{array}{l}\text { Reforma de grandes } \\
\text { equipamentos (ex. } \\
\text { AF) sem assistência } \\
\text { técnica. Engenharia } \\
\text { reversa de detalhe e } \\
\text { básico. Manufatura de } \\
\text { grandes equipa- } \\
\text { mentos. }\end{array}$ \\
\hline $\begin{array}{c}\text { (5) } \\
\text { Intermediário }\end{array}$ & $\begin{array}{l}\text { Monitoramento } \\
\text { completo, controle e } \\
\text { execução de: estudos } \\
\text { de viabilidade, } \\
\text { busca, avaliação, e } \\
\text { seleção, e atividades } \\
\text { de financiamento. }\end{array}$ & $\begin{array}{l}\text { Engenharia básica de } \\
\text { plantas individuais. } \\
\text { Expansão da planta } \\
\text { sem assistência } \\
\text { técnica. Provisão } \\
\text { intermitente de } \\
\text { assistência técnica. }\end{array}$ & $\begin{array}{l}\text { Aprimoramento } \\
\text { contínuo de processo. } \\
\text { Desenho de sistemas } \\
\text { automatizados } \\
\text { estáticos. Integração } \\
\text { de sistemas } \\
\text { automatizados de } \\
\text { processo e PCP. } \\
\text { Alongamento } \\
\text { rotinizado de } \\
\text { capacidade. }\end{array}$ & $\begin{array}{l}\text { Aprimoramento conti- } \\
\text { nuo em especificações } \\
\text { próprias. Desenho, } \\
\text { desenvolvimento, } \\
\text { manufatura e comer- } \\
\text { cialização de aços } \\
\text { complexos e de alto } \\
\text { valor sem assistência } \\
\text { técnica. Certificação p/ } \\
\text { desenvolvimento de } \\
\text { produto (ex. ISO 9001). }\end{array}$ & $\begin{array}{l}\text { Continua E básica e } \\
\text { de detalhe e ma- } \\
\text { nufaturo de plantas } \\
\text { individuais (ex. AF, } \\
\text { Sinter), Manutenção } \\
\text { preventiva. }\end{array}$ \\
\hline $\begin{array}{l}(6) \\
\text { Intermediário } \\
\text { Superior }\end{array}$ & $\begin{array}{l}\text { Elaboração e exe- } \\
\text { cução próprias de } \\
\text { projetos. Provisões } \\
\text { de assistência } \\
\text { técnica em decisões } \\
\text { de investimentos. }\end{array}$ & $\begin{array}{l}\text { Engenharia básica da } \\
\text { planta inteira. } \\
\text { Provisão sistemática } \\
\text { de assistência técnica } \\
\text { em: estudos de } \\
\text { viabilidade, } \\
\text { engenharia de } \\
\text { aquisição, de detalhe, } \\
\text { básica, e partida da } \\
\text { planta. }\end{array}$ & $\begin{array}{l}\text { Integração entre } \\
\text { sistemas operacionais } \\
\text { e sistema corporativo. } \\
\text { Engajamento em } \\
\text { processos de } \\
\text { inovação baseados } \\
\text { em pesquisa e } \\
\text { engenharia. }\end{array}$ & $\begin{array}{l}\text { Adição de valor a aços } \\
\text { desenvolvidos interna- } \\
\text { mente. Desenho e } \\
\text { desenv. de aços extra } \\
\text { complexos e de alto } \\
\text { valor agregado. Engaja- } \\
\text { mento em proje-tos de } \\
\text { desenho e desenvolvi- } \\
\text { mento com usuários. }\end{array}$ & $\begin{array}{l}\text { Continua E básica e } \\
\text { detalhe de equipa- } \\
\text { mento para planto } \\
\text { inteira de aço e/ou } \\
\text { componentes paro } \\
\text { outras indústrias. } \\
\text { Assistência técnica } \\
\text { (ex. reformo de AF) } \\
\text { para outras empresas. }\end{array}$ \\
\hline $\begin{array}{c}(7) \\
\text { Avançado }\end{array}$ & $\begin{array}{l}\text { Gestão de projetos } \\
\text { de classe mundial. } \\
\text { Desenvolvimento de } \\
\text { novos sistemas de } \\
\text { produção via P\&D. }\end{array}$ & $\begin{array}{l}\text { Engenharia de classe } \\
\text { mundial. Novos de- } \\
\text { senhos de processos e } \\
\text { P\&D relacionado. }\end{array}$ & $\begin{array}{l}\text { Produção de classe } \\
\text { mundial. Desenhos e } \\
\text { desenvolvimento de } \\
\text { novos processos } \\
\text { baseados em E e } \\
\text { P\&D. }\end{array}$ & $\begin{array}{l}\text { Desenho e } \\
\text { desenvolvimento de } \\
\text { produtos em classe } \\
\text { mundial. Desenho } \\
\text { original via E, P e D. }\end{array}$ & $\begin{array}{l}\text { Desenho e manufatura } \\
\text { de equipamentos de } \\
\text { classe mundial P\&D } \\
\text { para novos } \\
\text { equipamentos e } \\
\text { componentes. }\end{array}$ \\
\hline
\end{tabular}

Fonte: Figueiredo (2001; 2002; 2004) Chaves: $\mathrm{E}=$ engenharia; $\mathrm{PCP}=$ planejamento e controle da produção, $\mathrm{CQ}=$ controle de qualidade, $\mathrm{AF}=$ alto forno, $\mathrm{ZD}=$ zero defeito, $\mathrm{JIT}=$ just in time; $\mathrm{TQC} / \mathrm{M}=$ controle da qualidade total/gestão 
Isso se torna muito relevante, ao se tratar de países em desenvolvimento, onde além dos extremos de níveis de capacidade, é importante não negligenciar os estágios intermediários de evolução, ou seja, é fundamental considerar a importância das melhorias contínuas, das inovações incrementais, as adaptações em produto e processo. Essas considerações são muito significativas para economias em desenvolvimento como a do Brasil.

\subsubsection{Trajetórias de acumulação de capacidade tecnológica}

O sucesso no desenvolvimento tecnológico depende de um grande esforço em longo prazo. Exige o desenvolvimento de mecanismos de aprendizagem e acúmulo de experiência. De acordo com Dahlman et al.(1987), a tecnologia não deve ser vista simplesmente como um produto a ser comprado e vendido. Deve ser entendida como um método para se fazer algo. Isso implica ter informação sobre o método, o meio para conduzi-lo, e um pouco de compreensão do método. Além disso, o termo tecnologia refere-se não apenas aos processos físicos que transformam insumos em produtos e as especificações para as entradas e saídas, mas aos processos e ao arranjo organizacional que conduzem à transformação.

A capacidade necessária para adquirir, assimilar, usar, adaptar, alterar ou criar tecnologia pode ser colocada em três categorias, conforme Dahlman et al.(1987): produção, investimento e inovação. A capacidade de produção é necessária para operar as instalações produtivas. Reflete-se em eficiência produtiva e na capacidade de se adaptar as operações às circunstâncias de mercado. A capacidade de investimento é necessária para estabelecer novas instalações produtivas e ampliar as instalações existentes. Ela se reflete em custos de projeto e na capacidade de desenvolver projetos sob medida que atendam as circunstâncias do investimento. A capacidade de inovação, por sua vez, é necessária para criar novas tecnologias. Reflete-se na capacidade de melhorar a tecnologia ou para desenvolver novos produtos ou serviços que melhor atendam necessidades específicas.

Em economias em desenvolvimento, as trajetórias de acumulação de capacidade tecnológica seguidas pelas empresas tem um comportamento diferente quando comparadas às de empresas em economias desenvolvidas. Conforme Dahlman et al.(1987), a sequência típica de empresas de economias desenvolvidas segue a trajetória inovação-investimento-produção, enquanto que em empresas de economias em desenvolvimento, seguem uma trajetória contrária, ou seja, produção-investimento-inovação.

Bell (1997), citado em Figueiredo (2009), apresenta um modelo (que pode ser caracterizado como um modelo de escala tecnológica) de acumulação de capacidade tecnológica em 
empresas de países em desenvolvimento, como mostrado na Figura 5. Vale lembrar que se considera que uma empresa acumulou um determinado nível de competência quando ela se torna apta a alguma atividade tecnológica que não podia desempenhar anteriormente.

Figura 5: Trajetória de acumulação de capacidade tecnológica em empresas de países em desenvolvimento - modelo ilustrativo de catching-up

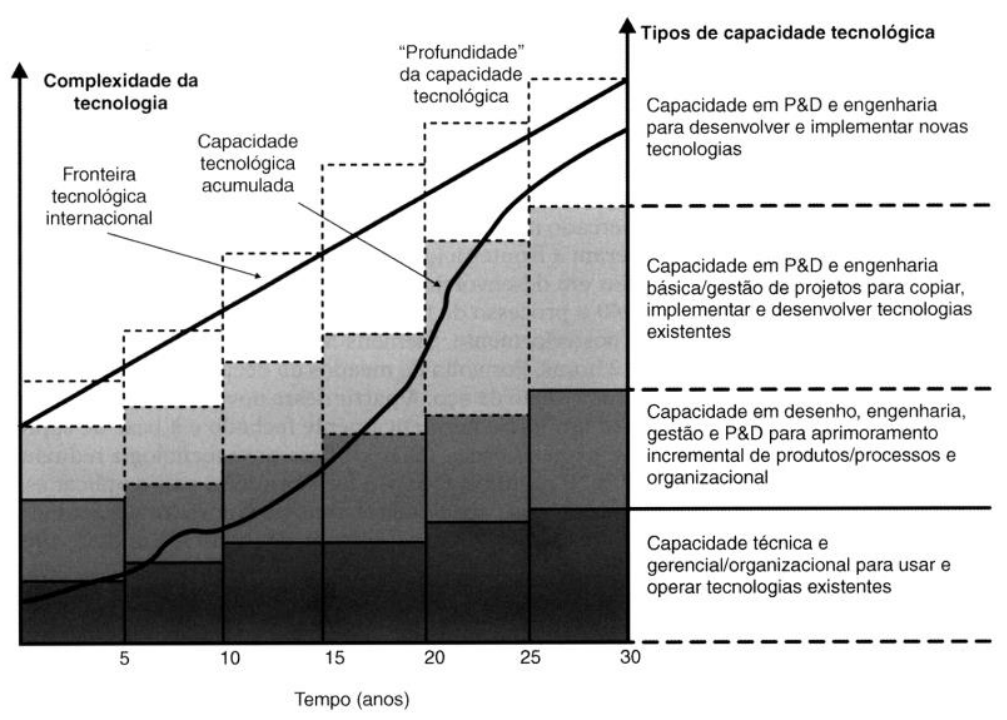

Fonte: Bell (1997), Figueiredo (2009)

De acordo com Figueiredo (2009), no eixo vertical esquerdo da figura tem-se a complexidade de uma tecnologia específica, que pode ser siderúrgica, eletrônica, etc. No eixo vertical direito são apresentados os tipos e níveis de capacidade tecnológica. Nessa classificação deve-se chamar a atenção para a distinção entre os tipos de capacidade de produção, que são aqueles voltados para operar ou usar tecnologias e sistemas de produção existentes, e de capacidades de inovação, que compreendem as capacidades para mudar, inovar tecnologias e sistemas de produção existentes, e que, por sua vez, variam de básicas até níveis de fronteira internacional de inovação. A curva retilínea representa a fronteira tecnológica internacional.

Vale destacar que a curva da fronteira internacional está em constante movimento, já que as empresas e os países que lideram tal fronteira fazem esforços contínuos em pesquisa e desenvolvimento para que possam continuar garantindo não só sua liderança industrial, mas também econômica e política. A outra curva ascendente ilustra a trajetória de acumulação de capacidade tecnológica de empresas de economias em desenvolvimento. Pode-se notar que tal trajetória se inicia quando as empresas inovadoras de economias industrializadas já acumularam estoque substancial de capacidade tecnológica. Em outros termos, significa dizer que é gerada uma diferença tecnológica (ou gap tecnológico) constante entre empresas de países desenvolvidos e em desenvolvimento. Nesse sentido, o grande desafio das empresas 
pertencentes a países em desenvolvimento é o de avançar e diminuir essas diferenças, aproximando da fronteira internacional, acumulando capacidades tecnológicas em nível de produção e inovação.

Entretanto, o desenvolvimento de capacidades tecnológicas de produção e de inovação não é uma garantia de alcance da fronteira. Muitas empresas não alcançam tais níveis, pois o acúmulo de capacidades tecnológicas é difícil e complexo, requer tempo e envolve diversos tipos de esforços de aprendizagem tecnológica e recursos financeiros, além de ser incerto e arriscado (FIGUEIREDO, 2009).

Outro aspecto importante a ser destacado em relação à fronteira tecnológica internacional é que sua curva pode não ser sempre retilínea. Isto ocorre quando do surgimento de uma inovação do tipo radical ou de novas empresas no mercado internacional com tecnologias inéditas, gerando uma descontinuidade na trajetória existente (Figura 6). Tal circunstancia pode aumentar mais a diferença ou gap tecnológico entre empresas de economias desenvolvidas e em desenvolvimento.

Figura 6: Trajetória de acumulação de capacidade tecnológica em empresas de países em desenvolvimento - modelo ilustrativo frente a descontinuidades

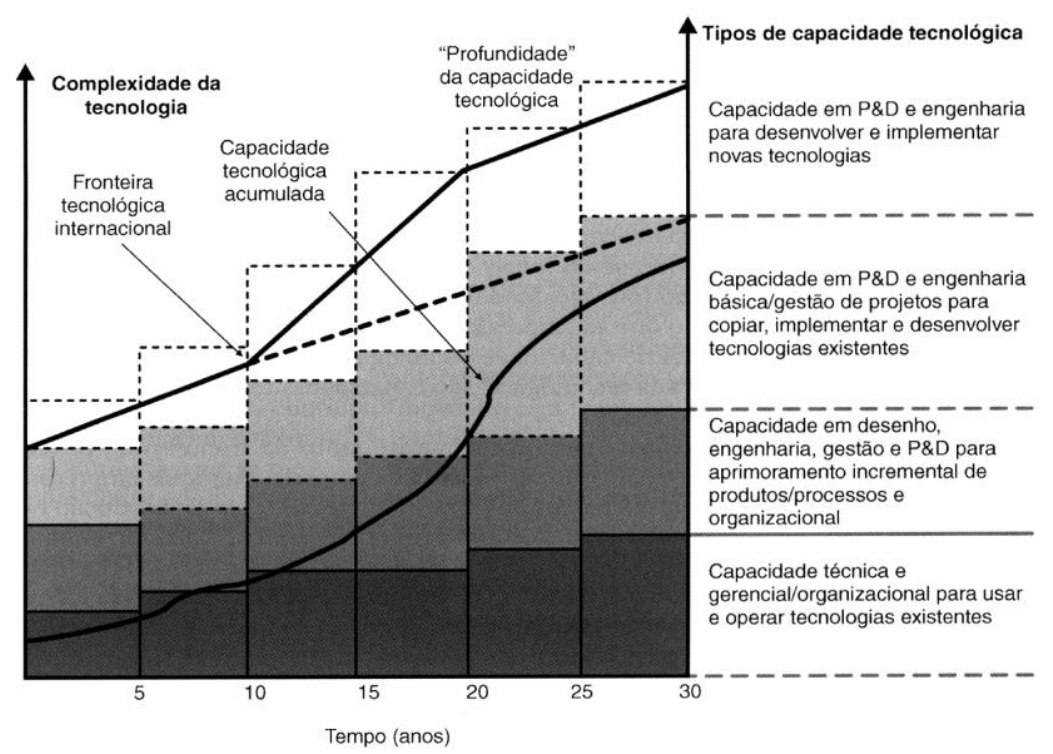

Fonte: Bell (1997, Figueiredo 2009)

Sendo assim, pode-se afirmar que existem duas trajetórias de acumulação tecnológica: uma trajetória de alcance, também definida como catching-up, que se refere ao movimento de acumulação tecnológica, próximo à fronteira internacional; e uma segunda, que representa uma trajetória de ultrapassagem ou overtaking, que conduz a empresa para uma posição na própria fronteira tecnológica, tornando-a líder de mercado em nível mundial. 


\subsubsection{Movimento de catching-up e overtaking}

Conforme visto, o processo de desenvolvimento tecnológico dos países em processo de catching-up tem sido um pouco diferente do mesmo processo nos países avançados. De acordo com Cimoli et al. (2006), todas as formas de conhecimento possuem um aspecto tácito significativo, altamente complementar às informações codificadas, que as torna incorporadas a pessoas ou organizações e um tanto difícil em relação à transmissão. Com efeito, está é uma das razões fundamentais pelas quais o processo de catching-up tecnológico dos países em desenvolvimento continua sendo uma tarefa desafiadora, mesmo considerando-se uma época atual, caracterizada pela globalização e livre fluxo das informações. É importante destacar que o processo de catch-up (ou emparelhamento) envolve inovações de maneira essencial. As atividades inovadoras que impulsionam o processo diferem das inovações buscadas por uma grande parte das pesquisas e do aprendizado tecnológico das economias mais avançadas. As novas tecnologias e as novas práticas que vão sendo incorporadas, embora sejam novas nos países que buscam emparelhar-se aos mais avançados, estão, de modo geral, bem estabelecidas nos países situados na fronteira tecnológica (CIMOLI, et. al., 2006).

Nos países avançados, a trajetória tecnológica pode ser representada pelo modelo de Abernathy e Utterback (1978). Segundo este modelo, citado em Kim (2005), os ramos industriais e as empresas desenvolvem-se ao longo de uma trajetória composta de três estágios, a saber: fluido, transitório e específico. De acordo com este modelo, as empresas que adotam uma nova tecnologia exibem um padrão fluido de inovação. A taxa de inovação de produtos, de caráter mais radical do incremental, é alta, e a tecnologia do novo produto é muitas vezes imatura, dispendiosa, e não confiável, porém, satisfaz a demanda de algum nicho de mercado, cumprindo assim sua função. Nesta fase, as mudanças nos produtos são frequentes, assim como as mudanças no mercado e, assim, o sistema de produção permanece fluido e a organização precisa de estrutura flexível para responder com rapidez e eficácia às mudanças no mercado e na tecnologia.

À medida que as necessidades do mercado se tornam melhor compreendidas e que as tecnologias de produto alternativos vão convergindo ou desaparecendo, tem-se início uma nova fase de transição em direção ao projeto de um produto dominante e de métodos de produção em série, com melhor desempenho e preços competitivos.

À medida que um ramo industrial e seu mercado amadurecem, e que a concorrência nos preços vai se tornando mais intensa, o processo de produção torna-se mais automatizado, integrado, sistematizado, específico e rígido, dando origem a um produto altamente 
padronizado. Nesse momento o foco da inovação desloca-se para melhorias incrementais no processo em busca de maior eficiência. Numa ultima fase desse estágio, os ramos industriais são, normalmente, transferidos para países em processo de catching-up, onde os custos de produção são mais baixos. Ocorre também, nessa fase, uma perda de competitividade dos países avançados face àqueles países. O referente modelo é representado pela parte superior da Figura 7.

Figura 7: Integração das trajetórias tecnológicas de empresas de países industrializadas e em desenvolvimento

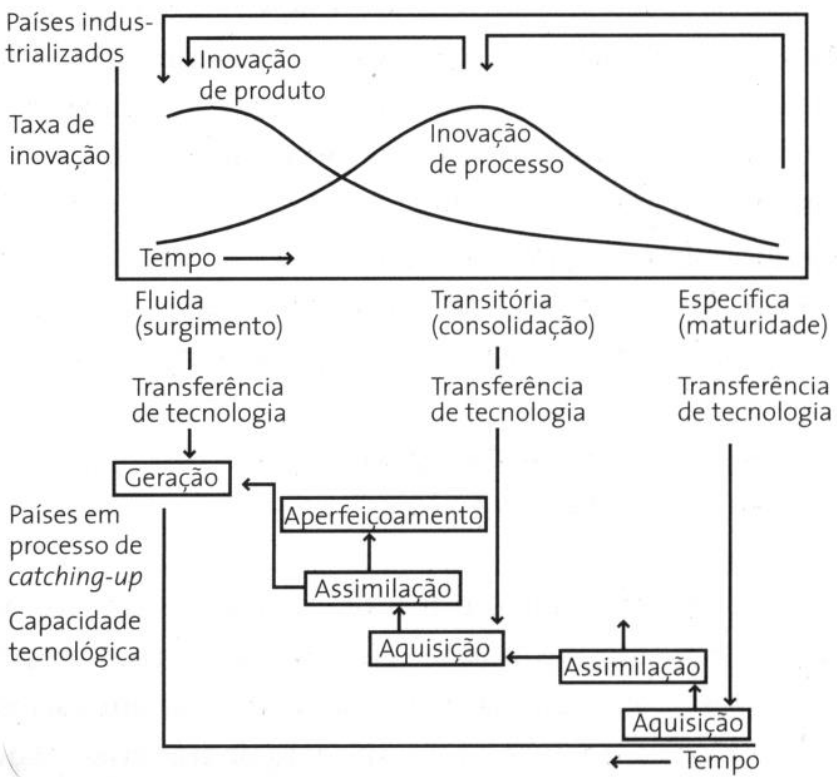

Fonte: Kim (2005)

No estágio fluido a frequência das inovações de produto radicais é alta, mas diminui rapidamente. Já na fase transitória, são as inovações de processo que ocorrem com frequência. No estágio específico, por sua vez, as inovações tanto de produto quanto de processo, ocorrem com pouca frequência.

Quanto à trajetória tecnológica de empresas de países em desenvolvimento, Kim (2005) desenvolveu um modelo de três fases, a saber: aquisição, assimilação e aperfeiçoamento, conforme mostrado na Figura 7.

$\mathrm{Na}$ fase inicial do processo de industrialização, os países em processo de catching-up adquirem tecnologias estrangeiras maduras (correspondente ao estágio específico) dos países altamente industrializados. Desprovidos de capacidades internas para estabelecer as operações produtivas, as empresas locais desenvolvem processos de produção através da aquisição de pacotes de tecnologia estrangeira que incluem processo de montagem, especificações de produtos, know-how de produção, pessoal técnico, componentes e peças. A tarefa tecnológica 
imediata consiste na implementação da tecnologia estrangeira transferida para fabricar produtos, cuja tecnologia e mercado foram já testados e comprovados. Neste caso, somente os esforços de engenharia são exigidos. A assistência técnica estrangeira, importante na fase inicial, tem sua utilidade diminuída à medida que os técnicos locais adquirem experiência na produção e no design de produtos (KIM, 2005).

Apesar de não ocorrer uma transferência direta de tecnologias estrangeiras, a assimilação das tecnologias importadas permite às empresas locais se tornam capazes de desenvolver produtos afins através da imitação por engenharia reversa. Sendo assim, a assimilação relativamente bem-sucedida das tecnologias de produção e uma crescente ênfase na promoção de exportações, juntamente com o aumento da capacidade de pessoal das áreas de engenharia e de pesquisa cientifica levam a um aperfeiçoamento gradual da tecnologia. Ao longo dessa trajetória, durante a aquisição, a assimilação e o aperfeiçoamento dessas tecnologias, as empresas, as empresas nos países em processo de catching-up invertem a sequência de pesquisa, desenvolvimento e engenharia adotada pelos países desenvolvidos.

Por fim, é importante destacar que as empresas dos países em processo de catching-up que adquiriram, assimilaram e, algumas vezes aperfeiçoaram com sucesso as tecnologias estrangeiras maduras, talvez tenham por objetivo repetir o processo com tecnologias mais avançadas na fase transitória em países desenvolvidos. Caso sejam bem sucedidos, esses países poderão eventualmente acumular capacidade tecnológica nacional para gerar novas tecnologias na fase fluida e desafiar empresas nos países desenvolvidos. Quando um número significativo de ramos industriais atinge esse estagio, o país pode ser considerado desenvolvido (KIM, 2005).

É importante ressaltar que todas as experiências bem-sucedidas de catching-up e, às vezes, superação dos líderes econômicos prevalecentes envolveram construção institucional e medidas de políticas que afetam a imitação tecnológica, a organização de indústrias, padrões de comércio internacional, e direitos de propriedade intelectual. Certamente isso se aplica atualmente também, mesmo no contexto de uma economia mundial globalizada (CIMOLI et al., 2007).

Conforme visto acima, as empresas adquirirem capacidades tecnológicas, que inicialmente servem para operar tecnologias existentes. $\mathrm{O}$ acúmulo de novas capacidades possibilita o uso e a operação de tecnologias mais inovadoras, conduzindo as empresas para uma posição muito próxima da fronteira tecnológica de produção e/ou inovação. No entanto, as empresas podem, posteriormente, ser conduzidas para uma posição na própria fronteira e ultrapassarem 
aquelas que lá se encontram como lideres, caracterizando assim um movimento de ultrapassagem ou overtaking.

De acordo com Figueiredo (2009), o movimento de ultrapassagem ou overtaking pode envolver três tipos de movimento (Figura 8):

- Movimento ao longo de uma trajetória tecnológica existente a uma velocidade maior do que a das empresas que já alcançaram a fronteira internacional de inovação;

- Movimento em uma direção diferente à base de diferentes capacidades tecnológicas; e

- Movimento acelerado com mudança qualitativa na fronteira tecnológica internacional (combinação dos movimentos anteriores).

Figura 8: Trajetória de acumulação de capacidade tecnológica em empresas de países em desenvolvimento: modelo de catching-up e overtaking

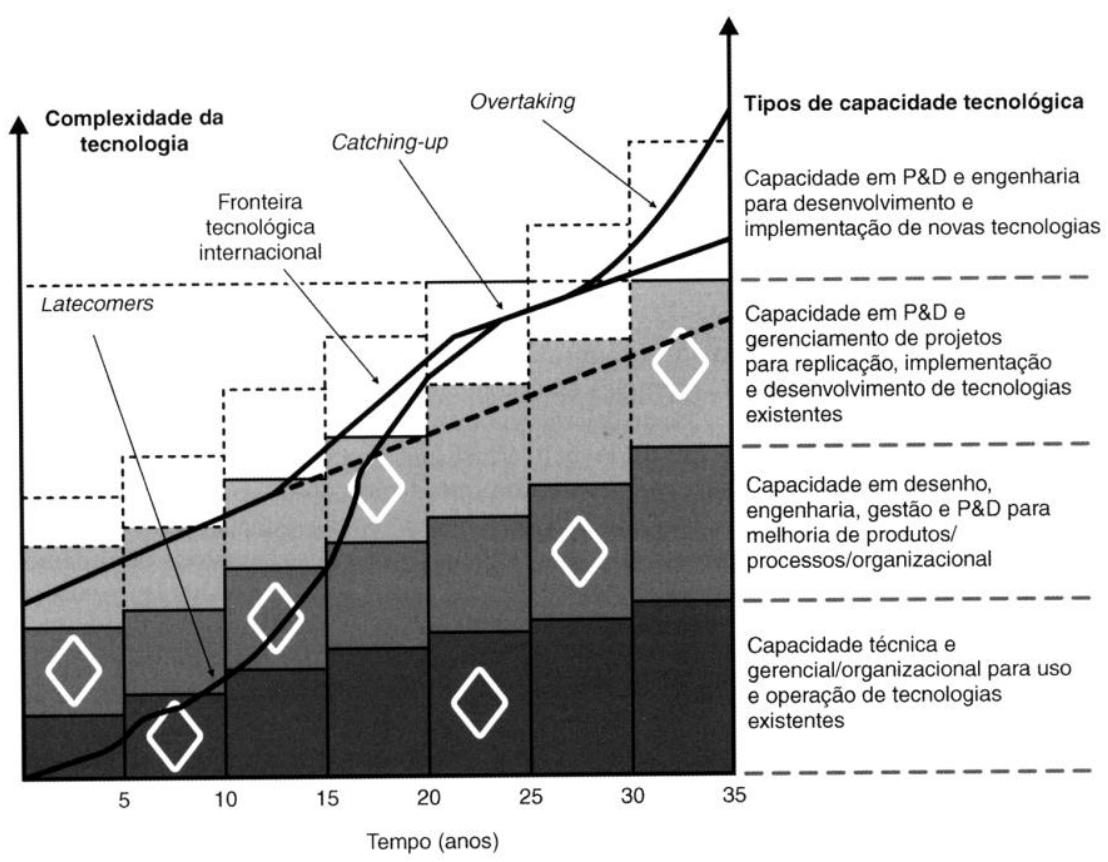

Fonte: Figueiredo (2009)

No primeiro caso, as empresas de países em desenvolvimento aceleram o processo de acumulação de capacidade tecnológica inovadora ao longo de uma trajetória tecnológica existente. Este percurso é realizado em uma velocidade maior do que aquelas empresas inovadoras que já se encontram na posição de liderança na fronteira tecnológica. Isto é, de um lado, encurtam o tempo de desenvolvimento de novos produtos e serviços e de outros tipos de inovação, avançando além do desempenho inovador de empresas líderes. De outro lado, podem pular alguns estágios específicos ao longo desse caminho. 
No segundo tipo, as empresas de países em desenvolvimento acumulam capacidades tecnológicas em uma direção de inovação significativamente diferente daquelas já estabelecidas por empresas líderes de países desenvolvidos. Neste caso, surge um novo segmento na fronteira tecnológica internacional, ou uma trajetória tecnológica variante.

Por fim, o terceiro tipo envolve uma combinação dos dois movimentos anteriores, caracterizado por uma aceleração de velocidade com mudança qualitativa na fronteira tecnológica internacional. Tal combinação permite às empresas de economias em desenvolvimento avançarem para a posição de liderança na fronteira tecnológica internacional.

\subsubsection{Estrutura do ambiente institucional: fontes para o aprendizado}

De acordo com Kim (2005), para as empresas de países em processo de catching-up podem existir várias fontes de aprendizado tecnológico. Tais fontes podem ser classificadas em três grupos: (a) comunidade internacional; (b) comunidade nacional; e (c) esforços internos das empresas. Há também cinco fatores importantes que influenciam significativamente o processo de aprendizagem: (i) ambiente de mercado e de tecnologia; (ii) políticas públicas; (iii) educação formal; (iv) sociocultural; e (v) estrutura organizacional. Essa estrutura do ambiente institucional pode ser representada pela Figura 9. As fontes nacionais e internacionais, bem como os fatores internos que influenciam o processo de aprendizagem, serão apresentados, a seguir.

Vale destacar na Figura 9, que a seta que parte da empresa em direção à comunidade internacional indica como a tecnologia estrangeira transferida para a empresa fortalece sua capacidade tecnológica, ao elevar o nível da base de conhecimentos existentes, que é um de seus componentes essenciais. Esse processo é com frequência chamado de transferência internacional de tecnologia (TIT). As implicações da TIT dos países desenvolvidos para os países em desenvolvimento são discutidas mais adiante, na subseção seguinte.

(a) Fontes internacionais de aprendizado tecnológico

A comunidade internacional constitui talvez a fonte mais importante de aprendizado tecnológico para as empresas de países em desenvolvimento e em processo de catching-up. As mudanças na trajetória tecnológica em países avançados criam oportunidades favoráveis aos países que estão colocando esforços para recuperar seu gap tecnológico. 
Na figura 9, a seta que parte da empresa em direção à comunidade internacional, mostra como a capacidade tecnológica existente permite a uma empresa em processo de catching-up explorar tecnologias por ela desconhecidas e disponíveis na comunidade internacional. A capacidade tecnológica identifica também outras fontes, complementares, de pessoal especializado. Permite também reconhecer o valor de novas informações, fortalecer o poder de barganha nas negociações de transferência tecnológica e assimilar o conhecimento transferido. A partir desse ponto, a novas oportunidades são buscadas pela empresa.

Figura 9: Fontes de aprendizado tecnológico em países de industrialização recente

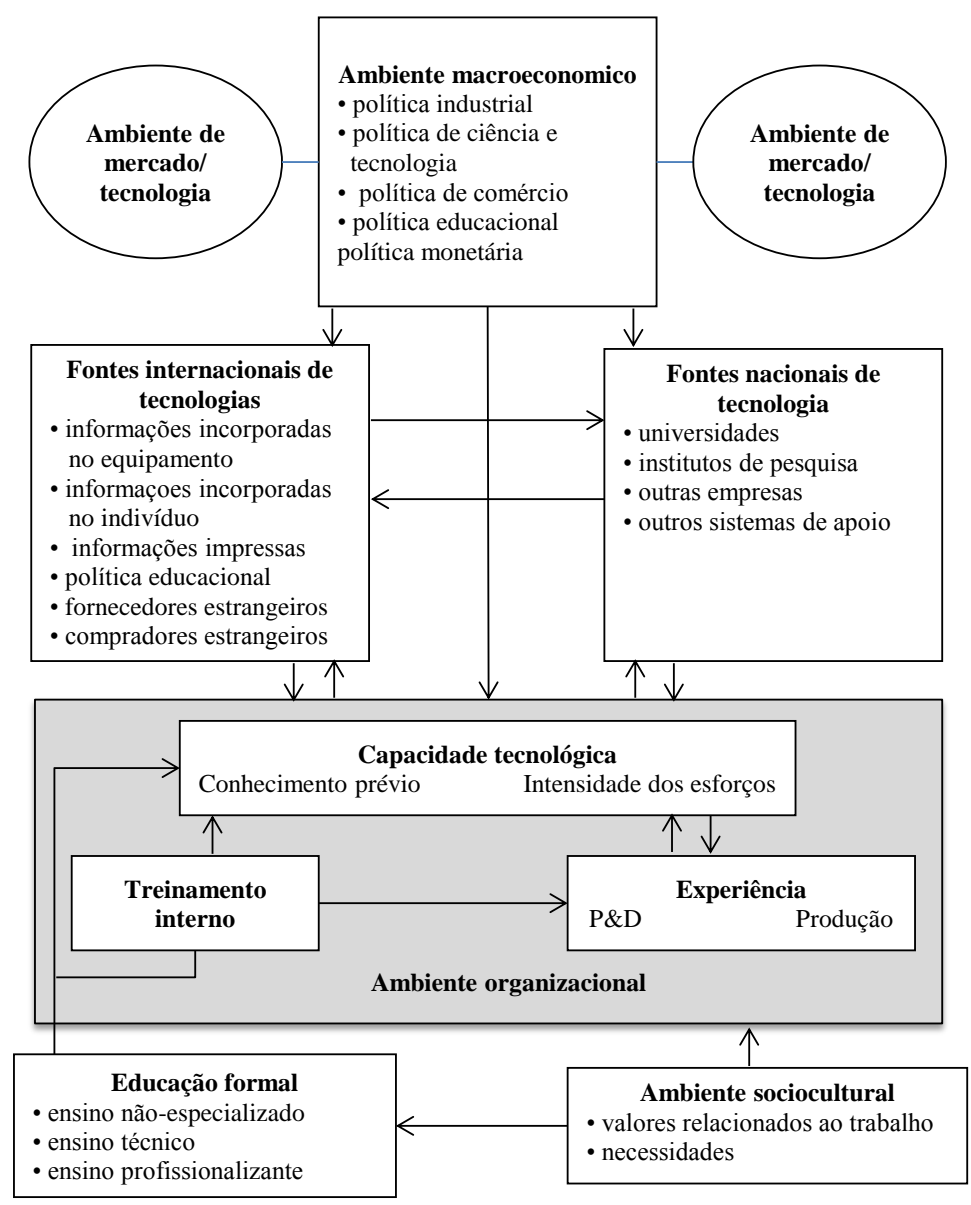

Fonte: Kim (2005)

(b) Fontes nacionais de aprendizado tecnológico

A comunidade nacional também é considerada importante. Ela permite identificar e explorar fontes de novas informações científicas e técnicas disponíveis na economia em questão, tais como universidades locais, institutos governamentais de $P \& D$ e outras agências públicas de apoio, os compradores e fornecedores, e outras empresas inseridas na economia nacional.

Nesse contexto são importantes os projetos de pesquisa em conjunto com universidades e institutos de pesquisa, pois podem aumentar significativamente a capacidade tecnológica da 
empresa. Outra fonte importante, em especial para imitação e engenharia reversa, é a observação de equipamentos avançados, seja em feiras industriais ou utilizados por outras empresas.

(c) Esforços internos das empresas

Pela Figura 9 pode-se notar o mecanismo interativo entre a capacidade tecnológica existente na empresa e sua experiência de produção e em atividades de P\&D. Esta capacidade permite que a empresa opere e mantenha seus sistemas de produção de forma eficiente. É importante destacar que ela pode ser desenvolvida como um subproduto das operações produtivas por meio do aprendizado pela prática. Particularmente, isso é de grande relevância para as empresas de países em processo de catching-up.

A experiência da produção permite que elas reconheçam e explorem novas informações relevantes para determinados métodos e produção, com o objetivo de melhorarem seus próprios métodos. A capacidade tecnológica é gerada também como um subproduto das atividades de $\mathrm{P} \& \mathrm{D}$, em especial quando se trata de conhecimento mais tácito, mais difícil de assimilar. No entanto é importante ressaltar, conforme Cohen e Levinthal (1989), que quando o conhecimento externo torna-se mais difícil de ser assimilado, menos conhecimento a empresa assimilará para um dado esforço de P\&D. Nesse sentido, as atividades de P\&D são fundamentais, pois elas permitem às empresas que fiquem atentas para o significado de novos sinais externos e que explorem as informações disponíveis de forma mais eficiente.

Vale destacar que as três atividades (interações com a comunidade internacional, nacional e os esforços internos) interagem e se fortalecem entre si, ou seja, as interações com a comunidade internacional e nacional facilitam os esforços internos, enquanto que os esforços internos promovem interações com as comunidades externas, em ambos os casos por meio do processo de aprendizado tecnológico.

(d) Fatores que influenciam o processo de aprendizado

$\mathrm{O}$ fator ambiente de mercado e de tecnologia influencia, além da própria empresa, o comportamento dos fornecedores, clientes e formuladores de políticas, e as interações que ocorrem entre eles. O processo de mudanças tecnológicas e as forças de mercado que atuam sobre esses elementos forçam as empresas a intensificarem seus esforços para fortalecerem as atividades internas, bem como para desenvolverem sua capacidade tecnológica. Levam as empresas a intensificarem também suas atividades externas para fortalecerem seus processos de aprendizado a partir de fontes externas. 
O segundo fator, políticas públicas, podem impactar significativamente no processo de aprendizado tecnológico, por meio de políticas industriais, de comércio e de ciência e tecnologia. As políticas públicas afetam as interações das empresas tanto com a comunidade internacional, ao regulamentar o afluxo de tecnologias estrangeiras, quanto com a comunidade nacional, na medida em que influenciam a disponibilidade e a eficácia das instituições de apoio nacionais e a qualidade das instituições educacionais. Em outros termos, essas políticas definem os ambientes macroeconômicos em as empresas tem de operar, atingindo direta e indiretamente o processo de aprendizado tecnológico.

O terceiro fator, a educação formal, em termos de estrutura e qualidade educacional, afeta a acumulação de capacidade tecnológica empresarial. Os recém-formados pelas instituições do sistema de educação formal proporcionam às empresas um contínuo ingresso de novos conhecimentos e de novas habilidades, que ampliam sua capacidade tecnológica para o futuro aprendizado.

$\mathrm{O}$ quarto fator, ambiente sociocultural, compreende as crenças, as normas e os valores da sociedade que impactam significativamente na formação ética do trabalho, a qual, por sua vez, influencia a mentalidade e o comportamento das pessoas nas empresas.

Por fim, o quinto fator, estrutura organizacional, refere-se a como as organizações são estruturadas e administradas. Tais características diferem entre as empresas e determinam, por sua vez, o nível de incentivos dentro da organização capaz de estimular a energia e as habilidades das pessoas. Um ambiente organizacional adequado favorece o aprendizado efetivo de seus membros e sua conversão em capacidade organizacional. Ambientes caracterizados por uma estrutura rígida cria barreiras para a criatividade das pessoas e retardam, por conseguinte, o aprendizado individual e organizacional.

\subsubsection{O papel das instituições e das políticas públicas}

As experiências históricas de crescimento econômico sustentado têm encontrado dentro de um rico conjunto de instituições complementares, normas de comportamento compartilhadas e políticas públicas, as condições que as tornam possíveis. Um elemento fundamental dos países que conseguiram se equiparar com sucesso aos países lideres, residiu no ativo apoio governamental ao processo de catching-up, envolvendo várias formas de proteção e subsídios diretos e indiretos. Em um sentido mais restrito, as políticas públicas, livres de restrições, têm sido importantes ingredientes das estratégias de desenvolvimento nacional, especialmente em países em processo de catching-up, com apoio e promoção do processo de aprendizado 
tecnológico (CIMOLI et al., 2006). Os diferentes domínios de intervenção das políticas, e como eles se projetam em diferentes medidas de políticas estão representados no Quadro 5, a seguir.

\section{Quadro 5: Áreas de intervenção e medidas de políticas}

\begin{tabular}{|c|c|}
\hline Áreas de intervenção de políticas & Medidas de políticas \\
\hline $\begin{array}{l}\text { (i) Oportunidades de inovação científica } \\
\text { e tecnológica }\end{array}$ & $\begin{array}{l}\text { Políticas científicas, cursos de pós-graduação, projetos tecnológicos } \\
\text { "de fronteira". }\end{array}$ \\
\hline $\begin{array}{l}\text { (ii) Aprendizado e aptidões tecnológicas } \\
\text { socialmente distribuídos. }\end{array}$ & Políticas educacionais e de treinamento em sentido amplo. \\
\hline $\begin{array}{l}\text { (iii) Medidas de apoio direcionadas à } \\
\text { indústria, afetando, por exemplo, os tipos de } \\
\text { firmas, etc. - primordialmente a estrutura, a } \\
\text { propriedade e as formas de governança das } \\
\text { firmas mercantis (locais versus estrangeiras, } \\
\text { empresas de propriedade familiar versus } \\
\text { companhias de capital aberto, etc.) }\end{array}$ & $\begin{array}{l}\text { Da formação de empresas de propriedade do Estado à privatização } \\
\text { das mesmas, das políticas para "campeões nacionais" a políticas que } \\
\text { afetam os investimentos de empresas transnacionais, passando por } \\
\text { toda a legislação relativa à governança empresarial. }\end{array}$ \\
\hline $\begin{array}{l}\text { (iv) As capacidades dos agentes econômicos } \\
\text { (em primeiro lugar as formas mercantis) em } \\
\text { termos de conhecimentos tecnológicos } \\
\text { incorporados a eles, a eficiência e velocidade } \\
\text { com que buscam o acesso a novos avanços } \\
\text { tecnológicos e organizacionais, etc. }\end{array}$ & $\begin{array}{l}\text { Cf. especialmente os pontos (ii), (iii) e também as políticas de P\&D } \\
\text { e políticas que afetam a adoção de novos equipamentos, etc. }\end{array}$ \\
\hline $\begin{array}{l}\text { (v) Os sinais e os incentivos econômicos } \\
\text { percebidos pelos agentes com fins lucrativos } \\
\text { (incluindo preços e taxas de lucratividade } \\
\text { reais e esperados, condições para a } \\
\text { apropriabilidade de inovaçôes, barreiras à } \\
\text { entrada, etc.) }\end{array}$ & $\begin{array}{l}\text { Regulações de preços, tarifas e quotas no comércio internacional, } \\
\text { regimes de Direitos de Propriedade Intelectual, etc. }\end{array}$ \\
\hline $\begin{array}{l}\text { (vi) Mecanismos de seleção (superpostas às } \\
\text { acima mencionadas). }\end{array}$ & $\begin{array}{l}\text { Políticas e legislação antitruste e que regulam a concorrência, o } \\
\text { ingresso no mercado e as falências; alocação de financiamento; } \\
\text { mercados para propriedade empresarial, etc. }\end{array}$ \\
\hline $\begin{array}{l}\text { (vii) Padrões de distribuição de informações } \\
\text { e de interação entre os diferentes tipos de } \\
\text { agentes (como clientes, fornecedores, } \\
\text { bancos, acionistas, administradores, } \\
\text { trabalhadores, etc.) }\end{array}$ & $\begin{array}{l}\text { Governança dos mercados de trabalho, dos mercados de produtos, } \\
\text { relações entre os bancos e o setor produtivo, etc., passando por todos } \\
\text { os arranjos coletivamente compartilhados para o controle e a } \\
\text { mobilidade do compartilhamento de informações no interior das } \\
\text { firmas, formas de cooperação e concorrência entre as firmas rivais, } \\
\text { etc. }\end{array}$ \\
\hline
\end{tabular}

Fonte: Cimoli et al. (2006)

Vale destacar, conforme Cimoli et al. (2006), que todos os países desenvolvidos possuem atualmente graus de intervenção relativamente altos, sejam eles conscientemente concebidos como políticas industriais ou não. As políticas e outras atividades de "engenharia institucional" afetam as capacidades tecnológicas de organizações individuais e corporativas, e o ritmo em que elas conseguem aprender. As combinações apropriadas de políticas podem ajudar a promover novas trajetórias de desenvolvimento. 


\subsubsection{Transferência tecnológica: o processo de transferência internacional de tecnologia}

O debate sobre Transferência Internacional de Tecnologia (TIT) surgiu a partir dos anos 60, no contexto do pensamento econômico desse período, sendo o paradigma neoclássico o ponto de partida. A partir dos anos 80 , com o surgimento das ideias evolucionistas, contrapontos à visão neoclássica são feitos e um novo debate sobre TIT é colocado. A tecnologia, sendo um elemento necessário para a produção e comercialização de bens e serviços, constitui-se em objeto de comércio e adquire um preço de venda, comportando-se, assim, como uma mercadoria (SABATO, 1979, p.62).

Ao se tratar o comércio de tecnologia entre países desenvolvidos e países em desenvolvimento observa-se um desequilíbrio nas relações que envolvem a transferência tecnológica. A estrutura inadequada e subdesenvolvida, criada nos países periféricos ao longo de seu processo de industrialização, configurou uma incapacidade de gerar suas próprias soluções tecnológicas, e, por conseguinte, criou-se uma considerável dependência tecnológica dos países centrais. A corrente dependista evidencia as assimetrias entre países desenvolvidos e em desenvolvimento, ao tratar da comercialização entre eles, a venda e a compra de tecnologia. O surgimento da dependência tecnológica, conforme Stewart (1977, p.116), ocorre quando a maior fonte de tecnologia encontra-se no estrangeiro, e no caso dos países do terceiro mundo, a principal fonte está nos países avançados.

Um país é caracterizado como mais dependente tecnologicamente se todas as tecnologias vindas do estrangeiro forem de um único país, do que se tiverem origem em vários outros. A comercialização da tecnologia ocorre quando ela se torna parte de um sistema de propriedade e sua transferência não mais é gratuita. O conhecimento, então, passa a ser monopolizado, comprado e vendido. Configura-se, portanto, um controle dos detentores do monopólio e uma fraqueza dos compradores. O preço da tecnologia, nesses termos, vai depender muito do poder de barganha de ambas as partes. Vale destacar que os países desenvolvidos também importam tecnologias, no entanto, o fato de eles também exportarem, gera maior poder de barganha, do que para aqueles (em desenvolvimento) que, fundamentalmente, só importam. Logo, conforme destaca Stewart (1977, p.122-123) as desvantagens da dependência tecnológica recaem, sobretudo, quando se há um fluxo unidirecional (apenas recebimento de tecnologia), e não uma troca de tecnologias (recebimento e fornecimento). Algumas das consequências negativas, no caso do fluxo unidirecional, dessa dependência, são os custos elevados; perda de controle sobre as decisões; tecnologia importada inapropriada; e falta de capacidade técnica local. 
A transferência de tecnologia embute em si um caráter de incerteza e uma assimetria da informação. O comprador da tecnologia ao adquiri-la não possui exatamente o valor daquilo que está sendo adquirido. O seu valor para o comprador, conforme Arrow (1962, p.615), não é conhecido até que ele tenha a informação. Assim, o vendedor retém os direitos de propriedade no uso da informação, e dada apropriabilidade incompleta, o potencial comprador acaba por basear sua decisão de compra em critérios não ideais. Para Fransman (1986, p.9-10) a dificuldade na aquisição do conhecimento se traduz em uma distribuição desigual, e isso ocorre quando do conhecimento não-apropriável e apropriável.

Os custos do conhecimento tecnológico podem ser relacionados tanto do lado da oferta quanto da demanda (Fransman, 1986, p.10). No caso da oferta é importante reconhecer que o conhecimento possui algum atributo de bem público. Seu custo é baixo (custo marginal é muito baixo), mas em função de seu uso monopolístico, o fornecedor busca sua venda a um preço mais alto possível. Pelo lado da demanda, em especial, o comprador depara-se com um grau elevado de incerteza na compra do conhecimento. Nestas circunstâncias o preço será indeterminado, variando entre um nível mínimo, determinado pelo custo de produção do conhecimento e um máximo, determinado pelo custo estimado do comprador em função das alternativas de que dispõe. Vale destacar também que o custo dessa transferência tem relação direta com a capacidade tecnológica do comprador, com o retorno obtido com a tecnologia transferida, e com o grau de monopólio do detentor da tecnologia.

Podem ser considerados também os custos diretos e indiretos da transferência de conhecimento. Os custos diretos de transferência de tecnologia, conforme Fransman (1986, p.13), estão relacionados diretamente com a aquisição da tecnologia. Podem ser explícitos ou implícitos. Os custos explícitos são aqueles evidenciados em contratos, relacionam-se a exploração de marca patente, serviços de engenharia, assistência técnica, etc.. Os custos implícitos caracterizam-se pelo "empacotamento" da tecnologia, ou seja, combina todos seus elementos de transferência (máquinas, equipamentos e treinamento) em um único pacote.

Desta forma, o vendedor obtém um preço maior do que se os elementos fossem vendidos separadamente. A ideia de pacote torna mais difícil entender o que se está comprando, em termos de valor e preço. Vale ainda destacar que, os insumos incluem cláusulas restritivas e preços de transferência. Os custos indiretos estão fundamentalmente relacionados à aquisição de tecnologia inapropriada, que incorre em uma inadequação da tecnologia às condições sociais e econômicas do local. Destaca-se também, que, por outro lado, a transferência de tecnologia pode gerar um baixo aproveitamento da tecnologia gerada localmente. 
Em resumo, os países periféricos são essencialmente importadores de tecnologia (normalmente do tipo incorporada) e não produtores. Adotam políticas protecionistas, mas com domínio das transnacionais em seu mercado interno. A falta de critério na seleção de tecnologia importada gera aquisições inapropriadas, que juntamente com a ausência de capacidade técnica local para operar a tecnologia resultam em mau uso e ineficiência. Conforme Stewart (1977, p.132), a atividade tecnológica requer aprendizagem, obtida pela experiência produtiva, quase ausente nas empresas industriais desses países. A aprendizagem tecnológica torna-se mais importante ao considerarmos que o conhecimento tecnológico não está somente atrelado ao conhecimento explicito (ou codificado), há uma segunda parcela, de natureza tácita (ou implícita), que dificulta a transferência, requer tempo, prática, adaptação, além de ser consideravelmente custosa. De acordo com Radosevic (1999, p.436), o catchingup tecnológico requer capacidade dos recursos humanos e capacidade de aprendizagem das empresas. A interação entre os bons níveis de capital humano e de atividades tecnológicas das empresas são essenciais neste processo.

A adoção de novas tecnologias requer, além da escolha adequada da tecnologia, uma capacidade local para sua operação. O caráter mercadológico da tecnologia, sua complexidade na determinação de seu valor, as assimetrias da informação, o poder de barganha dos detentores da tecnologia, o caráter tácito do conhecimento, que dificulta sua transferência, bem como a estratégia de "empacotamento da tecnologia", adotadas, em especial, pelas empresas transnacionais, proporcionam um elevado custo de transferência e aquisição tecnológica. Por fim, a importação de tecnologia é importante e de certo modo necessária, no entanto, ela precisa estar conciliada ao desenvolvimento tecnológico do país, precisam ser complementares.

\subsection{A inovação no contexto da indústria brasileira: fragilidades e potencialidades}

As últimas décadas, conforme já mencionado, foram marcadas por grandes transformações tecnológicas e econômicas. No entanto, o Brasil pouco se mobilizou para acompanhar essas tendências. Os investimentos de políticas públicas, nesse período, estavam voltados fundamentalmente para a racionalização dos processos produtivos, e o país permaneceu por muitos anos com uma indústria pouco estimulada para a inovação e diferenciação de produtos. Tal descompasso configurou um momento atual, caracterizado por uma relativa baixa competitividade por grande parte das empresas brasileiras; baixa taxa de inovação; pouca inserção no mercado internacional; e uma tímida trajetória de domínio tecnológico. 
A mobilização pela inovação no Brasil e as estratégias de desenvolvimento tiveram início muito recentemente, com a modernização do panorama institucional, derivado das novas diretrizes da PITCE - Política Industrial, Tecnológica e de Comércio Exterior -, anunciadas pelo governo federal em novembro de 2003, com o Plano de Desenvolvimento da Produção, em maio de 2008, e com o Plano Brasil Maior, em 2011. Tais iniciativas colocam a inovação como fator fundamental para que a indústria brasileira dê um salto de qualidade rumo à diferenciação de produtos, transformando, assim, sua própria estrutura industrial.

Do ponto de vista analítico, um esforço significativo também tem sido feito para o entendimento da complexidade e dos aspectos da inovação no contexto brasileiro. Uma demonstração de tal esforço é a pesquisa que abrange um conjunto de estudos sobre inovação, padrões tecnológicos e desempenho das firmas brasileiras, realizada pelo Instituto de Pesquisa Econômica Aplicada (IPEA), em convênio com o IBGE (DE NEGRI e SALERNO, 2005). Tal estudo reuniu o maior conjunto de informações sobre a indústria brasileira jamais reunido, envolvendo 72.000 firmas industriais e $95 \%$ do valor da produção industrial brasileira. A pesquisa mostra como a inovação e a diferenciação de produtos geram efeitos positivos sobre os salários, as exportações e o comércio exterior, o crescimento das firmas e a internacionalização das empresas brasileiras. Os dados mostram certa fragilidade da indústria brasileira e sustentam que o caminho para a competitividade, em especial para aquelas que atuam em mercados mais dinâmicos, é a inovação e diferenciação de produtos.

Por outro lado, há setores na economia brasileira que apresentam potencialidades significativas. Dentre os que se destacam, tem-se o setor metal-mecânico. Nesse setor, conforme enfatizado por Furtado (2004), se explicitam vários diferenciais positivos da indústria brasileira, configurando-se como uma indústria sólida diversificada, em especial o segmento de bens e capital. Considerada a fortaleza da indústria brasileira, nesse setor a atividade industrial possui uma elevadíssima endogenia, havendo um conjunto de princípios e técnicas, que pode ser aplicado, de forma horizontal e bastante difundida, a um grande número de produtos. A inovação na metal-mecânica tem sempre seu espaço, e as estratégias de inovação influem, de várias maneiras, nos processos competitivos. O elemento inovador está presente em todas as atividades, apesar das diferenças setoriais em relação a esforços e a resultados. O setor metal mecânico possui, internalizados na sua estrutura coletiva, numerosos ingredientes que propiciam a continuidade do processo de aprendizagem e o surgimento de oportunidades de inovação individuais e coletivas (FURTADO, 2004). 


\subsection{Síntese}

Este capítulo apresentou os principais conceitos sobre capacidade tecnológica e as bases analíticas nas quais este trabalho se apoia.

A revisão bibliográfica, à luz da abordagem evolucionista, das concepções de regime tecnológico e de padrões e sistemas setoriais de inovação, possibilitou extrair os principais aspectos internos e externos às empresas (em termos de dimensões e variáveis) que determinam seus processos de acúmulo de capacidade tecnológica. Tais dimensões e variáveis direcionam o propósito desse trabalho e são apresentadas no Quadro 6, a seguir.

Quadro 6: Dimensões e variáveis definidas para a pesquisa

\begin{tabular}{|c|c|c|c|}
\hline & Dimensões & Variáveis & Referências \\
\hline \multirow{20}{*}{ 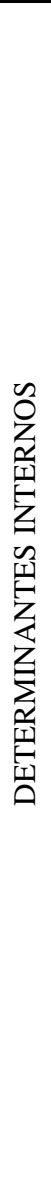 } & \multirow{4}{*}{ Recursos Internos } & Recursos Financeiros & \multirow{4}{*}{$\begin{array}{l}\text { Dahlman et al. (1987); Figueiredo } \\
\text { (2004); Dahlman et al. (1987); } \\
\text { Furtado (1994); Bell e Pavitt } \\
\text { (1995); } \quad \text { Furtado (1994); } \\
\text { Hasenclever e Cassiolato (1998); } \\
\text { Costa e Cunha (2001); Varum e } \\
\begin{array}{l}\text { Monteiro (2007); Radosevic } \\
\text { (1999). }\end{array}\end{array}$} \\
\hline & & Investimentos & \\
\hline & & $\begin{array}{l}\text { Recursos Humanos (capacitação para produção } \\
\text { e desenvolvimento de produtos) }\end{array}$ & \\
\hline & & Recursos Físicos (Máquinas e Equipamentos) & \\
\hline & \multirow{3}{*}{ Engenharia de Processo/Produção } & Flexibilidade da Produção & \multirow{3}{*}{$\begin{array}{l}\text { Lall (1992); Figueiredo (2004); } \\
\text { Bell e Pavitt (1995); Amsden } \\
(2001) ;\end{array}$} \\
\hline & & Confiabilidade da produção & \\
\hline & & Custo de produção & \\
\hline & \multirow{2}{*}{ Engenharia da Qualidade } & Gestão da Qualidade & \multirow{2}{*}{$\begin{array}{l}\text { Lall (1987); Figueiredo (2004); } \\
\text { Bell e Pavitt (1995); }\end{array}$} \\
\hline & & Controle da Qualidade & \\
\hline & \multirow{3}{*}{ Engenharia de Produto } & Atividades de P\&D & \multirow{3}{*}{$\begin{array}{l}\text { Breschi e Malerba (1997); Bell e } \\
\text { Pavitt (1995); Fransman (1986); } \\
\text { Stewart (1977); Cohen e Levinthal } \\
\text { (1989) }\end{array}$} \\
\hline & & Engenharia reversa & \\
\hline & & Inovações & \\
\hline & \multirow{4}{*}{ Aprendizagem Tecnológica } & Aquisição externa de conhecimento & \multirow{4}{*}{$\begin{array}{l}\text { Kim (2005); Breschi e Malerba } \\
\text { (1997; 2002); Stewart (1977); } \\
\text { Radosevic (1999); Lee (1996); } \\
\text { Tseng e Piller (2003); Van Dijk } \\
\text { (2000); Malerba e Orsenigo (2000) }\end{array}$} \\
\hline & & Aquisição interna de conhecimento & \\
\hline & & Socialização do conhecimento & \\
\hline & & Codificação do conhecimento & \\
\hline & \multirow{4}{*}{$\begin{array}{l}\text { Padrão de comportamento para a } \\
\text { inovação }\end{array}$} & Estratégia & \multirow{4}{*}{$\begin{array}{l}\text { Tidd e Bessant (2009); Burgelman, } \\
\text { Christensen e Wheelwright (2009); } \\
\text { Teece et al. (1990); Freeman } \\
\text { (1997) }\end{array}$} \\
\hline & & Processos & \\
\hline & & Organização & \\
\hline & & Interação e ações conjuntas & \\
\hline \multirow{8}{*}{ 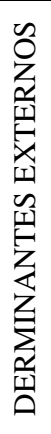 } & \multirow{5}{*}{ Ambiente macroeconômico } & Política cambial & \multirow{5}{*}{$\begin{array}{l}\text { Pich et al. (2002); Oreiro et al. } \\
(2009) ; \text { Lall (1987); Lundvall } \\
(2000 ; 1992) \text {; Bergek et al. (2008); } \\
\text { Sahal (1984); Rosenberg (1963)/ } \\
\text { Tidd e Bessant (2009); Cimoli et } \\
\text { al. (2006) }\end{array}$} \\
\hline & & Política comercial & \\
\hline & & Política tributária & \\
\hline & & Taxa de juros & \\
\hline & & Logística & \\
\hline & \multirow{3}{*}{ Sistema setorial de bens de capital } & Infraestrutura educacional & \multirow{3}{*}{$\begin{array}{l}\text { Lall (1987); Lundvall (2000;1992); } \\
\text { Bergek et al. (2008); Malerba } \\
\text { (2002); Pavitt (1984); Marsili e } \\
\text { Verspagen (2001); Cimoli et al. } \\
\text { (2006); Peneder (2003) }\end{array}$} \\
\hline & & Fomento à inovação & \\
\hline & & Política de Ciência e Tecnologia & \\
\hline
\end{tabular}


Onde tem-se:

\section{Determinantes internos}

Recursos internos. Visa identificar o grau de disponibilidade e qualidade de recursos de pessoal e físicos que as empresas dispõem para os processos de acúmulo de capacidade tecnológica. São também avaliados os potenciais financeiro e de investimentos das empresas.

Engenharia de processo/produção. Analisa o desempenho das competências ou habilidades de produção das empresas. Visa diferenciar a capacidade tecnológica de produção e de inovação das empresas, ou seja, capacidade que as empresas possuem para o uso/operação de tecnologias e de sistemas de produção existentes, e capacidade para gerar novas soluções tecnológicas. A capacidade tecnológica para inovação passa pela capacidade tecnológica de produção.

Engenharia da qualidade. Analisa o engajamento das empresas nas atividades voltadas para a área da qualidade. Visa diferenciar as empresas quanto à intensidade e práticas adotadas de gestão da qualidade.

Engenharia de produto. Visa identificar e diferenciar os esforços tecnológicos das empresas para a inovação. Os esforços tecnológicos determinam se as atividades estão voltadas para a melhoria do conteúdo tecnológico, para o desenvolvimento ou aperfeiçoamento de novos produtos e processos. Analisa-se o esforço empreendedor contínuo em termos de dispêndios para as atividades de pesquisa e desenvolvimento, e o grau de novidade atribuído ao produto, partir dessas atividades.

Aprendizagem tecnológica. Foca nos processos pelos quais a aprendizagem individual se converte em organizacional, já que a acumulação de saber tácito e de saber codificado, separadamente, não conduz à criação de uma base de conhecimentos na empresa. Visa determinar a intensidade em que os mecanismos de aprendizagem ocorrem ou estão presentes na organização, caracterizada como rara, intermitente (ou esporádica), e contínua.

Padrão de comportamento para a inovação. Visa analisar o padrão de comportamento que promove a capacidade de inovar das empresas, bem como as habilidades para organizar e gerenciar o processo. Visa diferenciar as empresas quanto à importância da inovação como elemento estratégico; ao grau de organização de seus processos; ao grau de interação das empresas e de ações conjuntas nos processos de inovação; e ao ambiente para a inovação. 


\section{Determinantes externos}

Ambiente macroeconômico. Visa analisar e diferenciar em qual intensidade as condições externas às empresas estimulam ou não os processos de aprendizagem e as estratégias para acúmulo de capacitações. O comportamento dos fatores macroeconômicos, tais como politica cambial, comercial e tributária podem inibir substancialmente os investimentos em recursos humanos e físicos para a capacitação.

Sistema setorial de bens de capital. Visa identificar as características do ambiente tecnológico que definem as estratégias adotadas pelas empresas. Busca-se analisar diferenciar as condições que determinam a demanda por novas tecnologias e os estímulos por investimentos em novos recursos e mecanismos de aprendizagem para atendê-las. Foca nos agentes heterogêneos que desenvolvem interações de caráter mercadológico ou não mercadológico para a geração, adoção e uso de novas (ou já estabelecidas) tecnologias específicas e para a criação, produção e uso de novos produtos pertinentes ao setor. Envolve a análise de clientes, fornecedores, fabricantes, universidades, instituições financeiras, agentes governamentais, entre outros. 


\section{A INDÚSTRIA DE BENS DE CAPITAL NO BRASIL}

\subsection{A importância do setor}

A indústria de bens de capital é uma das principais forças motoras do desenvolvimento econômico de um país. Sua importância justifica-se por poder incorporar, estimular e disseminar progresso para o restante da economia. Em outros termos, o setor de bens de capital está relacionado com a produção de outros setores, e, portanto, a introdução de novos produtos ou as modificações naqueles existentes, gera um aumento nos níveis de produção e de produtividade não só para o setor de transformação, mas em todos os outros setores diretamente a ele relacionados.

Esse processo exerce um efeito preponderante na sustentação do ritmo de crescimento da produtividade no longo prazo. Vale destacar também que os principais países que ilustram experiências bem-sucedidas de desenvolvimento via industrialização, tais como Inglaterra (no século XVIII), Estados Unidos e Alemanha (fim do século XIX), Japão e Coréia do Sul (século XX), e a China (neste século XXI), promoveram a criação de vantagens comparativas na indústria de bens de capital (Nassif e Ferreira, 2010).

O Brasil tem uma indústria de bens de capital constituída e, particularmente, apresenta um mercado interno de grande dimensão e com grande perspectiva de demanda futura, embora se tenha também presente, um atraso tecnológico.

$\mathrm{Na}$ política industrial brasileira recente, o setor de bens de capital foi incluído entre os prioritários. Tem como objetivo o aumento da eficiência econômica e do desenvolvimento e de difusão de tecnologias (aumento da capacidade de inovação) com maior potencial de indução do nível de atividade e de competição no comércio internacional (expansão das exportações através de produtos de maior valor agregado). Conforme Alem e Pessoa (2005), além de desempenhar um papel importante como difusor do progresso técnico, a existência de capacidade de produção nacional desses bens é indispensável para reduzir a restrição externa ao crescimento.

O setor de bens de capital, de acordo com Nassif e Ferreira (2010), representa quase $15 \%$ do valor adicionado pela indústria de transformação brasileira, conta com diversos segmentos prontos para competir internacionalmente e com alguns outros com elevado potencial de demanda futura, induzida, por sua vez, pelos grandes investimentos projetados, em especial no setor de petróleo e gás e infraestrutura. Nesse sentido, são expressivas as possibilidades de alcançar domínio tecnológico em segmentos nos quais o Brasil ainda não dispõe de vantagem 
comparativa e de aumentar expressivamente a participação da indústria no mercado global, seja via exportações ou investimento direto no exterior.

\subsection{Evolução do setor de bens de capital no mundo}

A produção industrial mundial, historicamente, é concentrada nos países desenvolvidos, os quais detêm grande parcela no valor adicionado mundial. Todavia, a partir da década de 1990, com a abertura comercial dos países periféricos, a participação no valor adicionado industrial dos países desenvolvidos tem diminuído, conforme apresentado na Tabela 1. Em especial, no contexto produtivo mundial da indústria de máquinas e equipamentos, o Brasil representou em 2010 apenas $0,6 \%$ do total das exportações mundiais.

Tabela 1: Valor e participação do valor adicionado da manufatura mundial

\begin{tabular}{llcccccc}
\hline & \multicolumn{3}{c}{ Valor adicionado da } & \multicolumn{3}{c}{ Participação do valor } \\
Grupo de países/Período & \multicolumn{2}{c}{ manufatura (US\$ bilhões) } & \multicolumn{2}{c}{ adicionado da manufatura (\%) } \\
& $\mathbf{1 9 9 2}$ & $\mathbf{2 0 0 2}$ & $\mathbf{2 0 1 2}$ & $\mathbf{1 9 9 2}$ & $\mathbf{2 0 0 2}$ & $\mathbf{2 0 1 2}$ \\
\hline Economias desenvolvidas & 4050 & 5070 & 5800 & $82 \%$ & $77 \%$ & $65 \%$ \\
Economias em desenvolvimento & 904 & 1520 & 3110 & $18 \%$ & $23 \%$ & $35 \%$ \\
\hline
\end{tabular}

Fonte: Unido Industrial Development Report (2013)

De acordo com a Tabela 1, de 1992 a 2012 a participação do adicionado da manufatura mundial em países de economias desenvolvidas passou de $82 \%$ para $65 \%$, enquanto que para os países em desenvolvimento houve um aumento de aproximadamente $100 \%$, passando de 18\% para 35 no mesmo período. Vale destacar também o significativo aumento do valor adicionado, em termos de produção (US\$), em 3,4 vezes.

No entanto, pode-se verificar, de acordo com a Figura 10, que a evolução na participação do valor adicionado, em economias em desenvolvimento, não ocorre em todos os países. Com exceção da China e da Índia, os outros países apresentam um decréscimo em relação à participação. Em outros termos, pode- se afirmar que o deslocamento da produção industrial mundial para economias em desenvolvimento, concentra-se fundamentalmente na China, a qual representa $50 \%$ da participação do valor adicionado.

É importante destacar que a China, tornou-se recentemente o maior exportador de máquinas e equipamentos, superando os EUA e a Alemanha, e também o maior consumidor, com apenas $18 \%$ do consumo aparente atendido por importações (ABDI, 2011). 
Figura 10: Valor adicionado da manufatura mundial nas principais economias em desenvolvimento (\%)
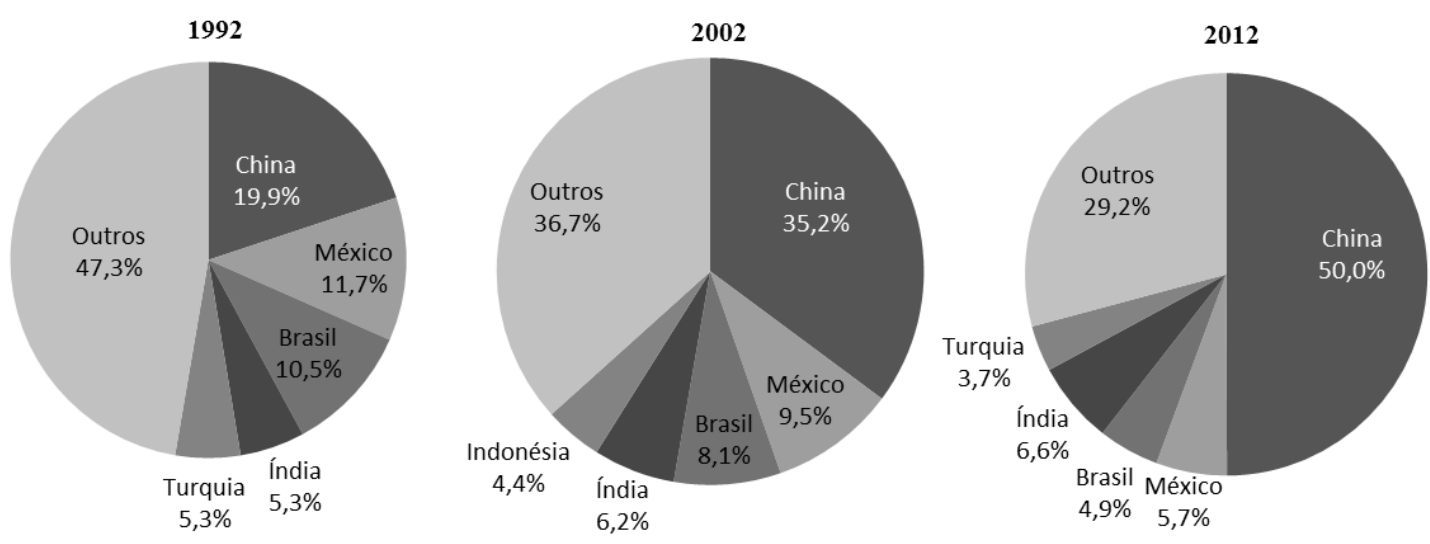

Fonte: Unido Industrial Development Report (2013)

Diante dessa nova configuração produtiva, o Brasil, dentre os países em desenvolvimento, tem sua participação reduzida em aproximadamente 50\% nas últimas duas décadas, passando de $10,5 \%$ em 2002, para 4,9\%, em 2012. Observa-se uma perda representativa na exportação no contexto internacional.

\subsection{Desempenho da indústria de bens de capital no Brasil}

O setor de bens de capital foi introduzido no Brasil na década de 1950 pelo Plano de Metas do governo de Juscelino Kubitschek (1956-61) e consolidou-se na segunda metade da década de 1970. Vale destacar que neste período, conforme Resende (1994), as empresas transnacionais (ETs) ocuparam um espaço importante na matriz industrial. O Estado expandia seus investimentos na indústria de insumos básicos enquanto as ETs se instalavam em setores que exigiam tecnologia avançada. Nota-se então, que foi através das ETs que a indústria de bens de capital do Brasil ganha certa complexidade tecnológica.

Na década de 1960 a indústria de bens de capital passou por duas fases distintas. Na primeira delas (1962-1967) essa indústria sofreu os impactos da crise econômica geral. Houve queda na produção e estagnação nas importações, e as demandas voltaram-se para os produtores internos. Com isso, em vários segmentos houve ampliação da participação da produção local na oferta total. Na segunda fase (1967-70), ao contrário da anterior, a indústria de bens de capital volta a crescer em grande ritmo. Entretanto, as importações ganharam certa liberdade (reduções tarifárias, isenções, política setorial ineficiente) e sua expansão, como consequência, contribuiu para retardar o desenvolvimento dessa indústria (RESENDE, 1994). Apesar do crescimento nesta fase, não se ampliou a capacidade instalada e não ocorreram mudanças qualitativas nos equipamentos fornecidos, em termos de dimensão e sofisticação tecnológica. 
A década de 1970 também foi marcada por um período favorável, com taxas de crescimento superiores a da produção industrial, com destaque para as empresas de bens de capital seriado. Em 1974 o governo implantou o Plano de Desenvolvimento Nacional II (II PND), gerando impactos importantes na participação relativa das empresas brasileiras (e na qualidade dos equipamentos) no atendimento da demanda local. Houve um amadurecimento tecnológico na indústria de máquinas-ferramenta com a fabricação de equipamentos de maior qualidade e sofisticação. Ao longo desta década as empresas de bens de capital buscaram uma aproximação do padrão tecnológico internacional. Os investimentos realizados no II PND deram preferência à ampliação da infraestrutura de energia e da capacidade produtiva de insumos básicos e a produção de bens de capital pesados, conforme destacado em Castro e Pires de Souza (1985).

Conforme Vermulm (1995), em relação à produção, na primeira metade da década de 1970 o crescimento foi mais intenso, tendo quadruplicado a produção de bens de capital, em especial a de bens seriados. A produção de bens sob encomenda também apresentou crescimento importante, com $21,4 \%$ do valor total da produção de bens de capital no país.

Na segunda metade da década de 1970, a produção nacional de bens de capital cresceu, porém em proporção menor em relação ao período anterior. A partir de 1976, as taxas de crescimento do setor apresentam uma redução significativa, como consequência das primeiras indicações da crise econômica brasileira. Contudo, a produção de bens de capital sob encomenda continua crescendo a taxas elevadas (porém, menores do que no período anterior), na medida em que as empresas estatais garantiram demanda para esse segmento. No final da década de 1970 aproximadamente $70 \%$ da demanda por bens de capital sob encomenda tinham origem no setor público.

Em relação às importações, na primeira metade da década de 70 , houve um crescimento maior do que a produção nacional. Na segunda metade da década, ocorre a diminuição do coeficiente de importação, mas o valor das importações se mantem praticamente constante, em aproximadamente US\$ 4,0 bilhões. Em outros termos, verifica-se um importante avanço durante a década de 70, mas, também, uma certa rigidez nas importações, sobretudo de produtos com elevado conteúdo tecnológico. De certo modo, a importação de produtos de maior conteúdo tecnológico deve-se à falta de capacitação interna. Além desses fatores, a rigidez das importações também é resultado da política industrial adotada no período (VERMULM, 1995). 
A década de 1970 foi marcada pelo elevado coeficiente de importação, mas também pelos baixos coeficientes de exportação. Estima-se que para 1970, o coeficiente de exportação era de, apenas, cerca de 5\%. Entre 1970 e 1974 observa-se uma elevação do coeficiente em função do aumento significativo da produção interna. Em 1979, em decorrência da diminuição da taxa de crescimento do mercado interno, ocorre uma nova aceleração das exportações, apresentando um coeficiente em torno de 14\%. As exportações realizadas na década de 1970 eram fundamentalmente de produtos de baixa sofisticação tecnológica, e tinham como mercados principais os países da América Latina. Compreendiam bens de capital seriados e sob encomenda. Apesar do aumento da participação dos bens de capital sob encomenda, as exportações eram predominantemente de bens seriados.

A década de 1970 também foi marcada pelas políticas públicas adotadas para incentivar o investimento industrial. Conforme Vermulm (1995), dentre os principais instrumentos de política industrial, voltados para o setor, destacam-se:

- Benefícios fiscais: concedidos pelo Conselho de Desenvolvimento Industrial - CDI para projetos de implantação, modernização ou relocalização industrial. Os benefícios fiscais compreendiam redução ou isenção dos impostos de importação sobre produtos industrializados (IPI), e sobre circulação de mercadorias (ICM), para importação de bens de capital, partes, peças e componentes, sem similar nacional; para o comprador de um bem de capital nacional, o governo concedia crédito do imposto sobre produtos industrializados e depreciação acelerada para efeitos de cálculo do imposto de renda.

- Índice de nacionalização dos produtos: o CDI concedia os Certificados de Registro de Fabricação onde era conferido o índice de nacionalização do bem, exigido para a empresa ter acesso ao crédito oficial e às compras das empresas estatais.

- Concessão de financiamentos: criação de condições mais favoráveis para financiamento, por diversas agências oficiais tais como o Banco do Brasil, para a concessão de crédito subsidiado para aquisição de máquinas e implementos agrícolas; Banco Nacional de Desenvolvimento Econômico - BNDE, para concessão de crédito subsidiado para investimento; FINAME, para concessão de crédito subsidiado para a compra de máquinas e equipamentos; e EMBRAMEC, aportando capital de risco em empresas produtoras de bens de capital.

- Fundos específicos para desenvolvimento tecnológico: fundos específicos para o desenvolvimento tecnológico, concedidos somente às empresas produtoras nacionais. 
Destacam-se o FUNTEC, do BNDE, o FUNAT do Ministério da Indústria e do Comércio e outros geridos pela FINEP. A tais fundos, podiam ter acesso a eles.

- Compras estatais: criação dos Núcleos de Articulação com a Indústria (NAIs) que tinham a função de estimular e auxiliar a capacitação da empresa nacional produtora de bens de capital a partir do poder de compra estatal.

- Incentivos à capacitação tecnológica: Atuação dos instrumentos financeiros, do poder de compra estatal, da formação de recursos humanos, da organização da infraestrutura científica e tecnológica. Limitação da transferência de tecnologia pelo Instituto Nacional de Propriedade Industrial (INPI), obrigando a empresa nacional, do setor de bens de capital, a investir na sua capacitação tecnológica.

A atuação do Estado foi crucial para a expansão da indústria de bens de capital. Os instrumentos de política industrial atuaram na proteção de mercado, na concessão de incentivos fiscais e financeiros, na disponibilidade maior de crédito, apoio à capacitação tecnológica, entre outros. Foi possível, através das políticas, estimular a indústria nacional e preservar os interesses dos usuários de bens de capital. Dentre os instrumentos de financiamento vale destacar o papel da FINAME, que financiava até $80 \%$ do valor da máquina ou equipamento a ser comprado. A diversificação de seus programas de financiamento, posteriormente, permitiu a aquisição de bens de maior conteúdo tecnológico, com maior prazo para pagamento, em especial, os bens de capital sob encomenda.

No entanto, algumas desvantagens ou resultados desfavoráveis dessas políticas foram verificados. De acordo com Vermulm (1995), apesar de o Estado procurar incentivar o investimento industrial, as ações das políticas contribuíram também para deprimir a demanda por bens de capital de origem nacional, na medida em que o exame da similaridade envolvia certo grau de negociação. De certa maneira, a política adotada apresentava elementos de contradição, já que protegia a produção nacional da concorrência externa, mas também estimulava a importação de bens de capital. O estímulo à importação pôde ser verificado pelo coeficiente de importação da indústria de bens de capital, que foi superior à média da indústria de transformação. Como consequência, a indústria nacional de bens de capital se desenvolveu na produção de bens de menor conteúdo técnico, para a qual existia mercado interno, enquanto que os produtos de maior conteúdo tecnológico eram importados, com benefícios fiscais.

Vale destacar também, que outro instrumento de política politica industrial, que estimulava a importação de bens de capital, o BEFIEX. Nesse programa, a empresa que se comprometesse 
com um cronograma de exportação, poderia importar bens, isentos de impostos, sem, necessariamente, realizar-se o exame da similaridade. No entanto, os produtos importados com incentivos do Programa BEFIEX não necessariamente eram destinados à produção para o mercado externo. Como consequência, apesar de as exportações de bens industrializados serem estimuladas, a importação era facilitada, mesmo com existindo similar nacional. Em 1977, de acordo com Almeida (1983), das importações de bens de capital, mais da metade $(51,9 \%)$ tiveram isenção tarifária,

Na década de 1980 a indústria de bens de capital no Brasil se encontrava diversificada e apresentava-se, conforme destacado em Torres et al. (1995), como a mais avançada em relação às indústrias dos demais países em desenvolvimento. A produção de máquinasferramenta, em especial, estava consolidada no segmento de máquinas convencionais. $\mathrm{O}$ processo de industrialização por substituição de importações (ISI), que havia predominado desde o início na década de 1930, chegava ao fim, não sendo mais visto como fonte de crescimento da produção industrial. No entanto, vale destacar que o processo de ISI assumiu um papel importante e contribuiu para o crescimento da produção interna, principalmente, nas fases iniciais da industrialização brasileira.

Todavia, a indústria de bens de capital, quando comparada àquelas de economias avançadas, apresenta um atraso tecnológico, que reflete na participação das exportações mundiais. Apesar de o processo de industrialização por substituição de importações ter, de alguma forma, contribuído para a modernização do parque industrial, o resultado da política adotada por esse modelo limitou-se somente a produção de bens nacionais de menor conteúdo tecnológico. A importação de bens de maior intensidade tecnológica não era vedada e sempre superava as exportações. Em outros termos, a indústria nacional se concentrava na produção de bens de menor intensidade tecnológica (vedando a importação com similar nacional) e importava aqueles de maior conteúdo. Até o final da década de 1980, a complementaridade entre a produção nacional e a importação de bens mais sofisticados esteve fortemente presente (ARAÚJO, 2009). Essa realidade caracterizou a indústria de bens de capital brasileira como pouco competitiva, com pequena participação do setor no total da economia.

De acordo com a Tabela 2, o consumo aparente de bens de capital mecânico na década de 1980 apresenta um pico no ano inicial e oscilações nos anos seguintes. Entre 1981 e 1983 observa-se uma retração no mercado de bens de capital, reflexo da crise econômica brasileira, que retraiu nível de investimentos, representando uma queda na demanda. 
Tabela 2: Consumo Aparente de bens de capital mecânico (US\$ bilhões constantes de 1992)

\begin{tabular}{ccccccc}
\hline Ano & Produção & Exportação & Importação & $\begin{array}{c}\text { Consumo } \\
\text { aparente }\end{array}$ & $\begin{array}{c}\text { Coef. } \\
\text { Importação }\end{array}$ & $\begin{array}{c}\text { Coef. } \\
\text { exportação }\end{array}$ \\
\hline 1980 & 24,89 & 1,76 & 2,75 & 25,88 & $10,6 \%$ & $7,1 \%$ \\
1981 & 22,19 & 1,81 & 3,2 & 23,58 & $13,6 \%$ & $8,2 \%$ \\
1982 & 18,19 & 1,3 & 2,06 & 18,95 & $10,9 \%$ & $7,1 \%$ \\
1983 & 14,9 & 1,24 & 1,25 & 14,91 & $8,4 \%$ & $8,3 \%$ \\
1984 & 15,63 & 1,54 & 1,06 & 15,15 & $7,0 \%$ & $9,9 \%$ \\
1985 & 18,4 & 1,74 & 1,17 & 17,83 & $6,6 \%$ & $9,5 \%$ \\
1986 & 21,04 & 1,55 & 1,51 & 21 & $7,2 \%$ & $7,4 \%$ \\
1987 & 21,59 & 1,77 & 2,02 & 21,84 & $9,2 \%$ & $8,2 \%$ \\
1988 & 20,96 & 2,34 & 2,55 & 21,17 & $12,0 \%$ & $11,2 \%$ \\
1989 & 20,1 & 2,44 & 1,99 & 19,65 & $10,1 \%$ & $12,1 \%$ \\
1990 & 18,34 & 2,18 & 2,6 & 18,76 & $13,9 \%$ & $11,9 \%$ \\
\hline
\end{tabular}

Fonte: ABIMAQ/SINDMAQ

A mesma retração se verifica quanto às exportações, com coeficientes entre 7,1\% $38,3 \%$. Apesar dos projetos do PND II, não houve elevação dos índices de exportação. O mercado mundial de bens de capital apresentava um excesso de oferta e a indústria de bens de capital, devido às suas características estruturais e baixa capacidade tecnológica, possuía baixa competitividade internacional para aumentar seu coeficiente de exportação. Seus principais mercados de exportação, que se localizavam em países da América Latina, passavam por crises econômicas, com pouco dinamismo e mesma retração.

Com o retraimento do mercado interno, as importações nesse primeiro período também apresentam uma queda. O coeficiente de importação diminui de 132,6\% em 1981, para 8,3\% em 1983.

Após esse período de retração, o setor de bens de capital volta a apresentar crescimento. Entre 1984 e 1987 o crescimento da produção é de aproximadamente 38\%. Conforme Vermulm (1995), o mercado interno se reaquece, em função do esforço exportador da economia brasileira como um todo. Empresas de outros setores que assumiram estratégias mais competitivas, em relação ao mercado externo, investem fortemente para se modernizarem e competirem no mercado internacional. Entre 1984 e 1987 a capacidade instalada passou de $60 \%$ para $80 \%$. Alinhado ao crescimento da demanda interna tem-se o aumento das importações. Vale destacar, que para os bens de capital sob encomenda a participação no total da produção não aumentou. A principal motivação para isso foi a baixa demanda do setor público, responsável pela parcela principal de aquisição. A retração da demanda em bens de capital sob encomenda traz importantes consequências para a competitividade das empresas. 
A redução da escala de produção inibe e limita os processos de aprendizagem, a capacitação tecnológica de produção e de projeto, além de elevar os custos unitários.

No final da década de 1980 há uma queda na produção de bens de capital e nas exportações, mas um aumento nas importações. Ocorre uma instabilidade econômica brasileira, com taxa de câmbio sobrevalorizada. A condição financeira do Estado desfavorável gerou uma escassez de recursos para financiamento, limitando assim mais ainda a capacidade de exportação do setor. A participação de máquinas e equipamentos na Formação Bruta de capital fixo (FBCF) declina, significando uma nova retração do mercado interno.

Quanto às politicas públicas ocorrem algumas mudanças visando à estruturação do setor. A fim de diminuir o déficit público, os incentivos fiscais concedidos pelo CDI sofrem reduções. Em especial, os incentivos fiscais voltados para a importação de bens de capital, partes, peças e componentes, são eliminados. O Programa BEFIEX passou a ser o único meio de importar os bens de capital e insumos com redução do imposto de importação. Os incentivos fiscais para compra de bens de capital nacional continuaram existindo, bem como os certificados de registro de fabricação, que estabelecem os índices de nacionalização. Em outros termos, constata-se que os instrumentos de apoio a financiamento industrial, que formavam a base da política industrial nos anos da década de 1970, ao longo da década de 1980, foram modificados, na busca de restringir as importações de bens de capital no Brasil. O Programa BEFIEX foi estendido até 1990, onde ocorreu sua eliminação.

O apoio financeiro também passou por alterações. Em virtude das dificuldades apresentadas pela então economia brasileira, o volume de recursos aplicados pelo BNDES no setor industrial foi reduzido até meados da década de 1980. O mesmo verificou-se nas condições de financiamento. Somente em 1987 é que os recursos do BNDES, voltados para o setor industrial, tiveram aumento, todavia, as condições geradas pela crise financeira inibiram os investimentos.

É importante frisar que nesse período, uma nova estratégia de crescimento adotada pelo governo brasileiro excluía o setor de bens de capital do conjunto de setores considerados prioritários. A maior oferta de fundos e de subsídio financeiro estava atrelada, fundamentalmente, à agricultura e exportação. Com a eliminação de recursos, o setor passou a depender de taxas de juros mais elevadas e consequentemente investindo menos.

Modificações também ocorreram no Programa FINAME, voltado para bens de capital sob encomenda. O percentual de cobertura diminuiu, passando para 50 a 60\%, e o prazo, de 12 a 
96 meses. Houve um deslocamento de incentivos para o segmento de máquinas e equipamentos agrícolas, que passou a apresentar um percentual maior de cobertura.

Vale destacar que, conforme enfatizado por Vermulm (1995), a diminuição na participação do financiamento no valor das máquinas e equipamentos negociados contribui significativamente para a retração do mercado interno de bens de capital, já que o financiamento é estratégico para o setor. A aquisição de bens de capital raramente ocorre à vista, portanto, as condições de financiamento, tais como taxa de juros, prazos e garantias, desempenham um papel crítico no desenvolvimento do setor.

Na década de 1990, se desfaz a característica de complementaridade entre a produção nacional e a importação de bens mais sofisticados. Ocorre a abertura da economia brasileira e observa-se uma elevação do coeficiente de importações de bens de capital, porém sem o mesmo aumento na produção nacional. Verifica-se, novamente, uma instabilidade macroeconômica com retração do mercado interno, que são agravados pela combinação de juros elevados e sobrevalorização da moeda brasileira. Tais fatores determinaram, conforme destacado em Vermulm e Erber (2002 ), um mercado interno refreado para bens de capital, e favoreceram a substituição de máquinas nacionais por máquinas estrangeiras.

Para o setor de bens de capital, a retração do mercado combinada com a abertura às importações não foi considerada benéfica, especialmente entre 1994 e 1999 . O suprimento do mercado interno de bens de capital mecânico passa a contar com maior participação de produtos e componentes estrangeiros; as importações, antes complementares à produção nacional, passaram a competir com ela. Conforme Moreira (1999), a participação estrangeira no setor de máquinas e equipamentos registrou em 1997, 42\% da receita operacional líquida da indústria de transformação.

A produção dos componentes com maior tecnologia não é realizada no país, as etapas de produção mais sofisticadas (intensivas em mão-de-obra altamente qualificada), que adicionam maior valor agregado, permanecem localizadas nos países desenvolvidos. Ocorre também, nesse período, um aumento da participação das empresas transnacionais no setor de máquinas e equipamentos, as quais lideram a produção de todos os ramos da indústria de bens de capital, exceto o segmento de máquina-ferramenta, e predominam no segmento sob encomenda, cuja produção exige um conjunto de conhecimentos técnicos mais complexos. Mesmo com imposto de importação para importação de bens com similar nacional, ao longo da década de 1990 a indústria de bens de capital perdeu dinamismo e precisou passar por um processo de reestruturação produtiva (ARAÚJO, 2009). Essa reconfiguração, de acordo com 
Alem e Pessoa (2005), resultou em um enfraquecimento dos encadeamentos produtivos e tecnológicos, com perda do poder multiplicador e indutor da indústria.

Como consequência desse contexto, as empresas produtoras de bens de capital apresentaram baixos níveis de competitividade, limitaram seus esforços de desenvolvimento tecnológico, reduziram os investimentos em modernização do processo produtivo e, atrasaram o lançamento de novos produtos. Por conseguinte, o hiato tecnológico existente entre a indústria brasileira e a mundial na produção de bens de capital se amplia (VERMULM, 1995). Em outros termos, pode-se afirmar que a indústria de bens de capital no Brasil, de maneira geral, apesar de apresentar uma boa capacidade de fabricação, possui uma limitação no desenvolvimento tecnológico.

Na década de 2000 dois eventos caracterizaram o ciclo produtivo da indústria de bens de capital: a retomada de crescimento em 2004, e a queda de produção, verificada após a crise financeira internacional, em 2008. Vale dizer que o desempenho da indústria de bens de capital está atrelado ao ciclo de investimentos da economia. A taxa de investimentos, conforme Gráfico 1, registrou crescimento contínuo entre 2003 e 2008, passando a recuar em 2009, em consequência da crise financeira internacional.

Gráfico 1: Brasil - Formação bruta de capital fixo/produto interno bruto de 2003-2011

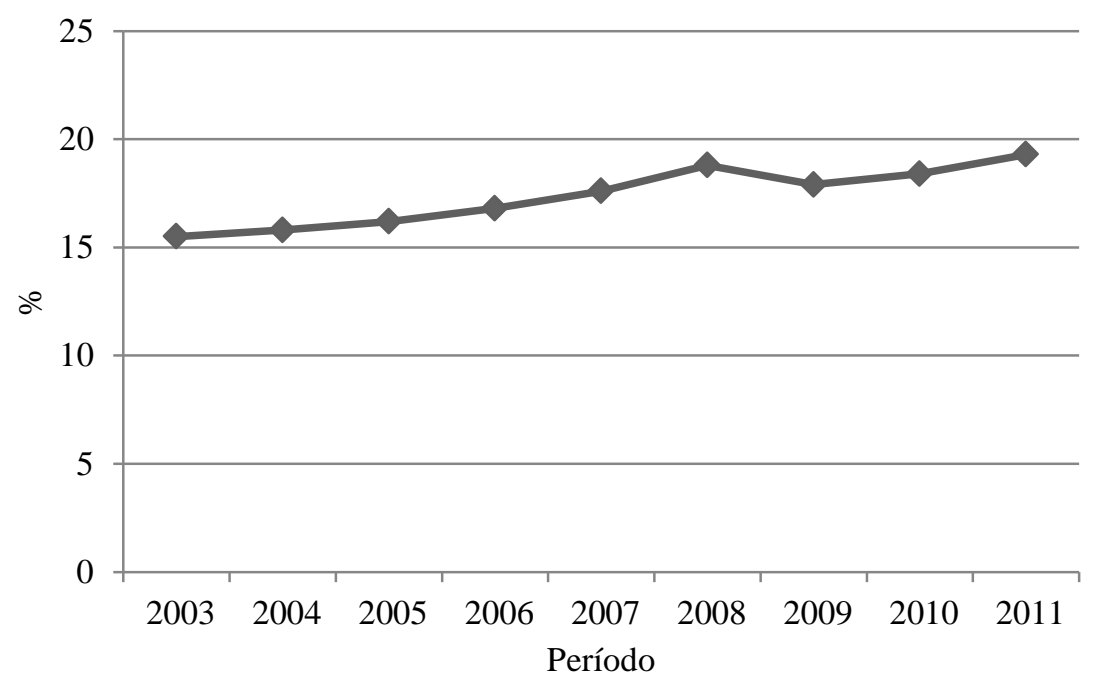

Fonte: Elaborado a partir de dados do IBGE

Em relação à produção física, de acordo com o Gráfico 2, pode-se observar que em 2004, com a retomada do crescimento econômico, verifica-se um aumento na demanda de bens de capital, tanto para os seriados como os não seriados. Em 2005, por sua vez, a política monetária adotada pelo governo (para controle da inflação) reduz os investimentos e a 
produção física desacelera, e volta a crescer novamente no ano seguinte. Ao longo de 2008, já com a crise financeira mundial instalada a produção diminui outra vez. A repentina estagnação do crédito, do investimento e da demanda, no Brasil e no mundo, em função da crise de 2008, fez da indústria de bens de capital um dos segmentos mais afetados.

Em 2009, após novos estímulos do governo, observa-se uma nova retomada no consumo e nos investimentos na indústria de bens de capital. A produção física voltou a crescer de maneira significativa até 2011, atingindo 51\% de aumento no período.

Em 2012, a baixa demanda do consumo e um aumento de produtos importados contribuíram para um desempenho negativo do setor, com queda de $11,8 \%$. No ano seguinte, a produção física apresentou um aumento de 13,3\%. Entretanto, de acordo com a Abimaq, em termos de faturamento, em 2013 houve uma queda de 5,3\% em relação ao ano anterior. E em 2012 o faturamento do setor já havia recuado 2,7\% em relação a 2011.

Gráfico 2: Produção física de máquinas e equipamentos de 2003-2013

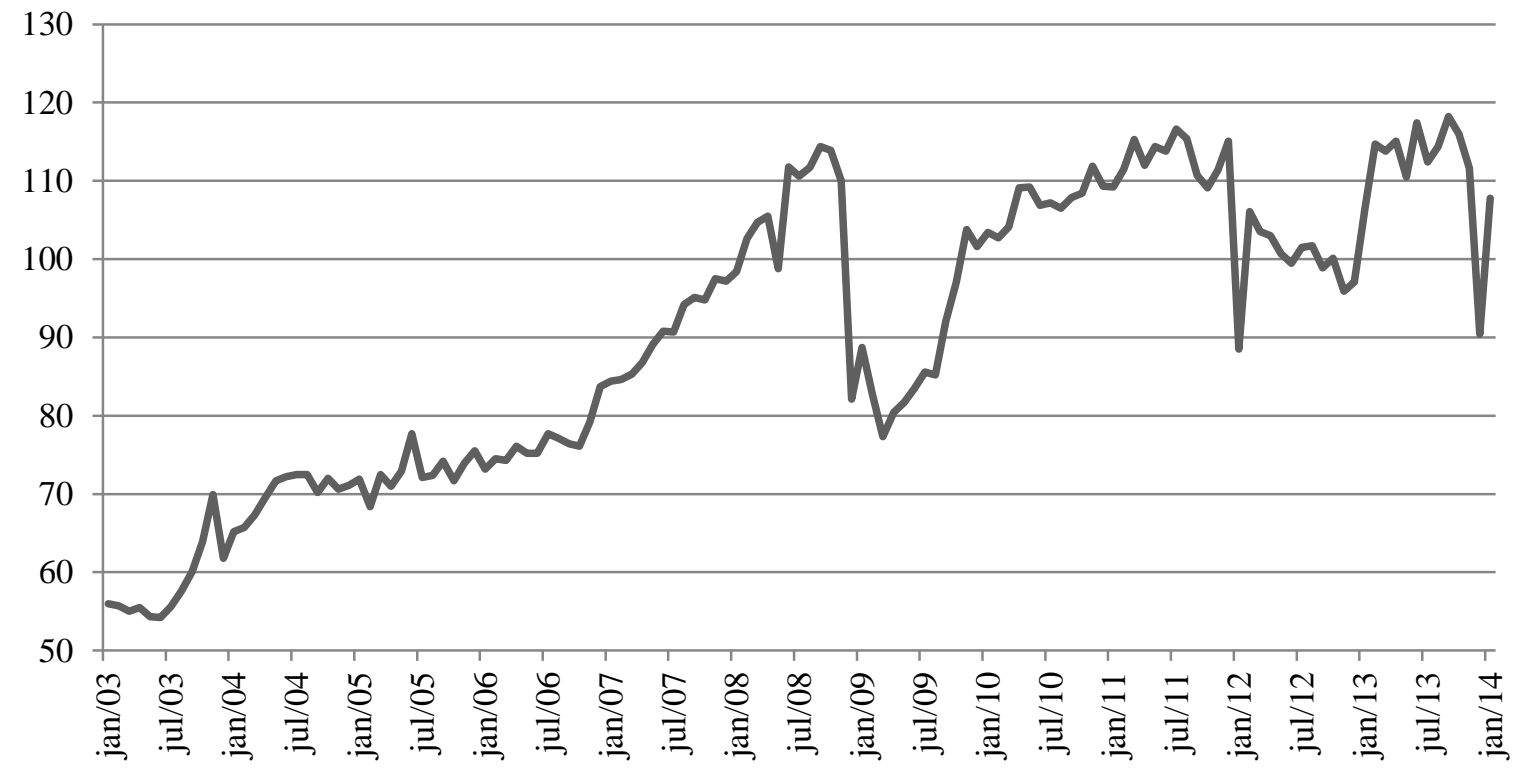

Fonte: IBGE/SIDRA: Índice de base fixa com ajuste sazonal 2012=100

A discrepância entre o desempenho da produção física e queda no faturamento decorre, fundamentalmente da diminuição das margens nos produtos. É importante destacar que a participação dos importados no consumo de máquinas e equipamentos apresentou um crescimento de 52\% em 2007 para 66\% em 2013, conforme dados da Abimaq. 


\subsection{Balança comercial dos bens de capital no Brasil}

O desempenho externo é um dos principais indicadores para avaliar a viabilidade e a capacidade de crescimento do setor no longo prazo. Nesse sentido, é importante analisar a balança comercial do setor, as exportações, importações, consumo aparente, conforme Tabela 3, e os países de origem e destino dos produtos.

Tabela 3: Desempenho da indústria de bens de capital mecânico (US\$ milhões)

\begin{tabular}{cccccccc}
\hline Período & Faturamento & Exportação & Importação & $\begin{array}{c}\text { Saldo } \\
\text { comercial }\end{array}$ & $\begin{array}{c}\text { Consumo } \\
\text { aparente }\end{array}$ & $\begin{array}{c}\text { Coef. } \\
\text { Importação }\end{array}$ & $\begin{array}{c}\text { Coef. } \\
\text { Exportação }\end{array}$ \\
\hline 2000 & 52,35 & 10,89 & 25,17 & $-14,28$ & 66,63 & 37,78 & 20,80 \\
2001 & 56,85 & 14,30 & 39,45 & $-25,15$ & 82,00 & 48,11 & 25,15 \\
2002 & 61,14 & 16,68 & 42,24 & $-25,56$ & 86,70 & 48,72 & 27,28 \\
2003 & 53,83 & 18,49 & 33,41 & $-14,92$ & 68,75 & 48,60 & 34,35 \\
2004 & 61,29 & 26,45 & 28,95 & $-2,50$ & 63,79 & 45,38 & 43,16 \\
2005 & 69,88 & 23,44 & 28,19 & $-4,75$ & 74,63 & 37,77 & 33,54 \\
2006 & 67,65 & 23,48 & 29,62 & $-6,14$ & 73,79 & 40,14 & 34,71 \\
2007 & 72,45 & 22,92 & 35,03 & $-12,11$ & 84,56 & 41,43 & 31,64 \\
2008 & 88,44 & 23,68 & 45,46 & $-21,78$ & 110,22 & 41,24 & 26,78 \\
2009 & 68,59 & 16,33 & 40,19 & $-23,86$ & 92,45 & 43,47 & 23,81 \\
2010 & 71,89 & 16,23 & 43,86 & $-27,63$ & 99,52 & 44,07 & 22,58 \\
\hline
\end{tabular}

Fonte: Elaborado a partir de dados da ABDI, IBGE e Abimaq (2013)

O consumo aparente de bens de capital mecânico de 2000 a 2002 apresentou um crescimento de $30 \%$. Entre 2003 e 2008, ocorre um crescimento de 60,3\% e o faturamento, beneficiado pelo aumento da demanda interna, cresce $64,2 \%$. As importações variaram em $80,6 \%$ e a produção interna, em $68,9 \%$. A produção interna não supriu mais do que $62,2 \%$ da demanda interna, em todo o período. Em 2002, tem-se a menor parcela de atendimento da produção interna à demanda interna, com 51,3\%. Em outros termos, apesar do crescimento da produção interna, foram as importações que tiveram maior representatividade, atendendo a demanda doméstica entre 37,8\% e 48,7\% no período. No período pós-crise, ou seja, 2009 e 2010 tem-se uma recuperação do setor, com aumento do faturamento e do consumo aparente, mas com aumento das importações também.

Quanto às exportações vale destacar, inicialmente, seu desempenho nas décadas anteriores. De acordo com Resende e Anderson (1999), as exportações de bens de capital entre os finais da década de 1970 e 1980 caracterizaram-se por constantes oscilações. Entre 1977 e 1981 o crescimento foi maior ao da produção total, com índice de coeficiente exportação passando de 36 a 106,2. No período compreendido entre 1982 e 1986 as exportações oscilaram em torno de uma média inferior ao de 1981. Entre 1985 e 1989 o coeficiente de exportação cresceu 
$39,7 \%$, enquanto a produção doméstica de bens de capital aumentou 17,5\%. Observa-se nesse período uma estagnação de investimento interno. Na década de 1990 as exportações apresentam um aumento em quase todo o período e o coeficiente de exportação tem um incremento de 92,4\%, passando de 96,6 em 1990 para 185,9 em 1997.

No início da década de 2000 as exportações brasileiras de bens de capital mecânico cresceram 2,4 vezes, passando de US\$ 10,89 bilhões em 2000, para US\$26,45 bilhões, em 2004, conforme Tabela 9 e Gráfico 3.

Gráfico 3: Balança comercial brasileira de bens de capital entre 2000 e 2010

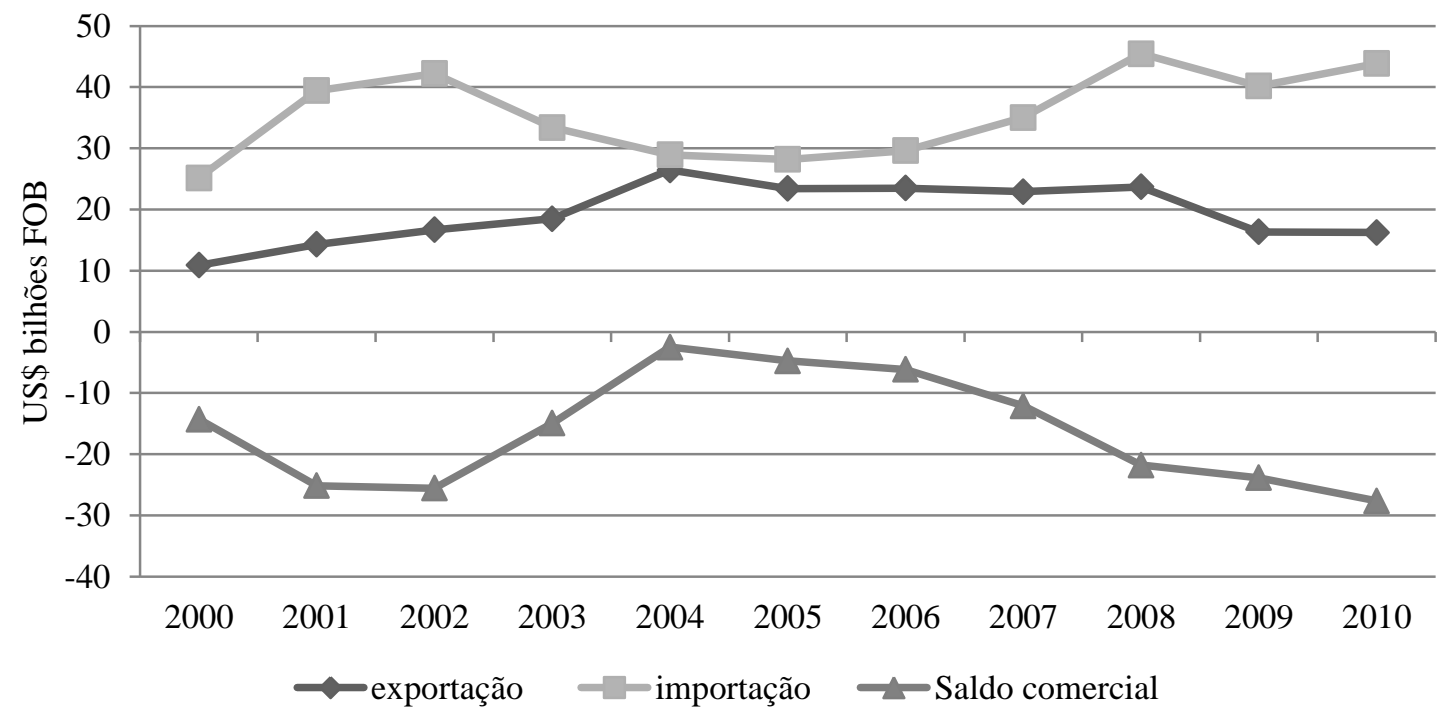

Fonte: Elaborado a partir de dados da ABDI, IBGE e Abimaq (2013)

Em 2005 houve uma queda de aproximadamente 13\% em relação ao ano anterior, que segue até 2008 com pequena oscilação. Em 2009, em decorrência da crise financeira internacional de 2008, uma nova queda mais acentuada se verifica. As exportações nesse ano diminuem em 45\% em ralação ao ano anterior, 2008, e segue nesse patamar até 2010.

Quanto ao destino das exportações, os países da América Latina são o principal, seguidos pelos EUA e Europa, conforme Gráfico 4. Dentre os países da América Latina destacam-se a Argentina, México e Chile. Na Europa, os principais países de destino das exportações são a Alemanha e Itália.

Vale notar que entre 2007 e 2010 as taxas de exportação apresentam maior importância para os países da América Latina e cresceram aproximadamente $22 \%$, enquanto que para os EUA as taxas diminuíram em mais de $28 \%$. A partir de 2010 verifica-se um comportamento 
contrário, ou seja, um decréscimo nas exportações para a América Latina e um aumento em relação aos EUA até 2013.

Gráfico 4: Principais destinos das exportações e participação no total exportado

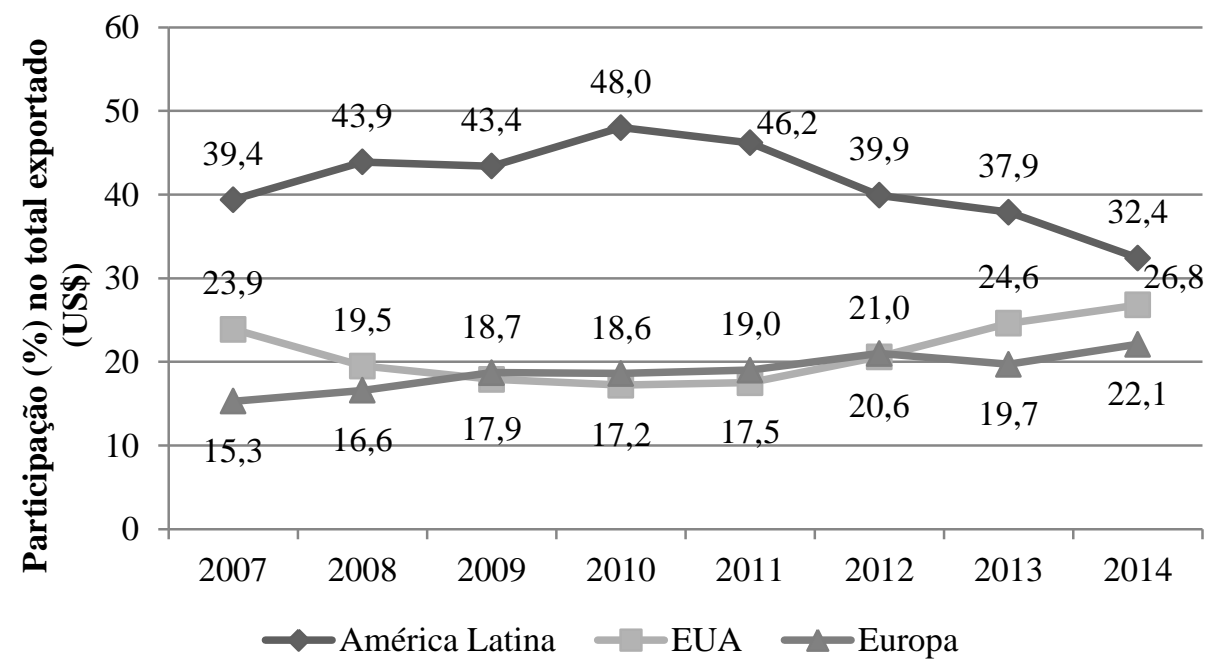

Fonte: Abimaq (2014)

Em relação à Europa, a participação nas exportações tem aumentado continuamente. Em 2007 o continente correspondia por 15,3\% das exportações, passando para 19,7\% em 2013, ou seja, um incremento de $28,7 \%$.

No que tange às importações, conforme Tabela 3, observa-se uma oscilação entre 2000 e 2006. Tem-se um aumento de $16,8 \%$ entre 2000 e 2002, e uma queda entre 2003 e 2006 . Vale destacar que essa oscilação deve-se, em grande parte, às flutuações do câmbio, com período de forte desvalorização, seguido de uma valorização acentuada.

Como consequência, o saldo comercial foi substancialmente negativo no primeiro período, entre 2000 e 2003, com redução posterior, entre de 2004 a 2006, cujo período demarcou simultâneo aumento nas exportações e diminuição das importações. No entanto, ao final da década, uma nova elevação nas importações e queda nas exportações determinam um novo aumento no déficit da balança comercial.

Quanto à origem das importações, em 2013, o país de maior representação são os EUA $(25,2 \%)$, seguidos pela China $(16,6 \%)$, Alemanha $(12,5 \%)$ e Itália $(7,8 \%)$, conforme Gráfico 5. 
É importante destacar que entre 2004 e 2013 a China passou de pequeno exportador a um exportador representativo de bens de capital mecânico para o Brasil. Em 2004 as importações da China eram de apenas 2,1\%, da Alemanha, 16,5\% e da Itália 8,2. Em 2007, a participação da China no total das importações de bens de capital, já ultrapassava a Itália, com 8,2\% frente a 7,6\%, e em 2010, a Alemanha, com 12,9\% frente a 12,4\%. Somente os EUA se mantiveram a frente da China entre 2004 e 2013. Entre 2004 e 2013, a China aumentou fortemente sua participação no mercado brasileiro, passando de 2,1\% em 2004, para 16,6\% em 2013, ou seja, um incremento de aproximadamente oito vezes.

Gráfico 5: Principais origens das importações e participação no total importado

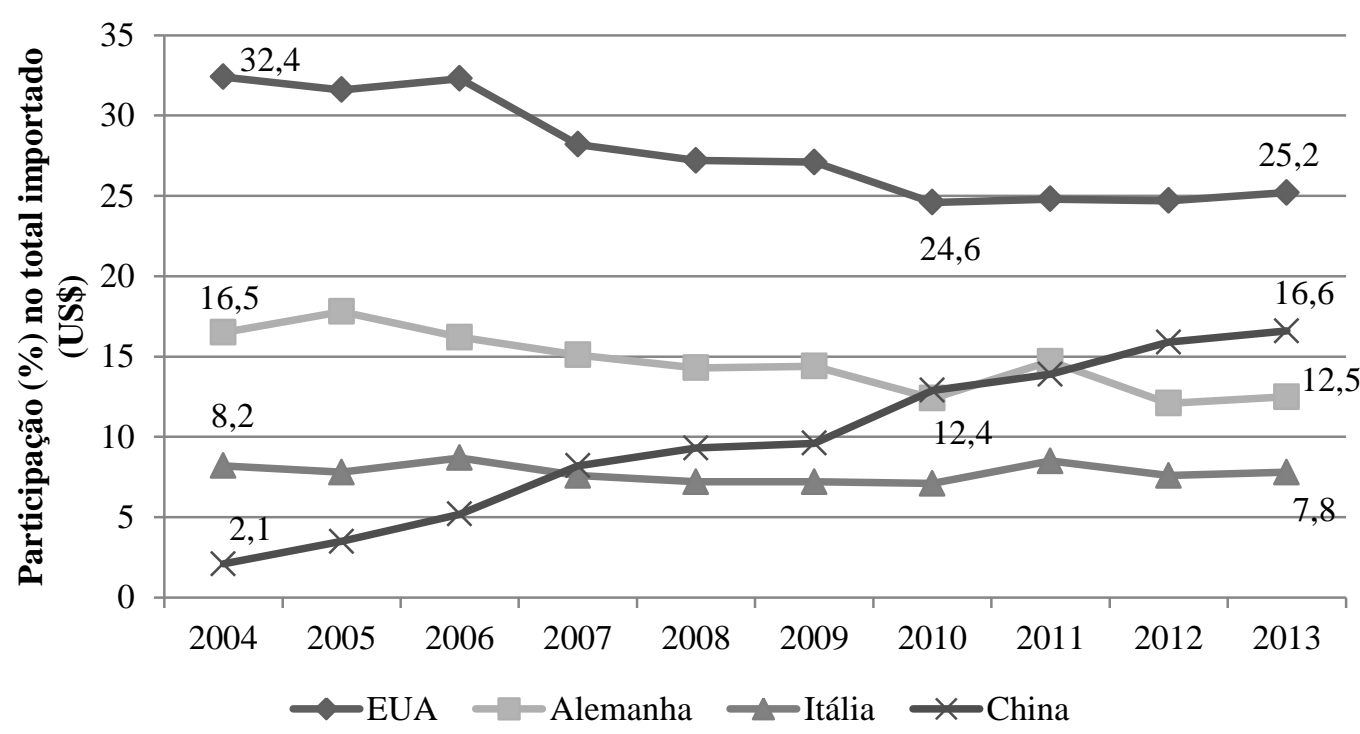

Fonte: Abimaq (2014)

É importante enfatizar que, de acordo com a Abimaq, o aumento da participação dos importados no setor de bens de capital mecânico, não decorre da ausência de capacidade física de produção, já que o nível de ocupação médio do setor é da ordem de $75 \%$, mas da baixa competitividade das empresas no Brasil, em especial, em termos de preço.

\subsection{Caracterização do segmento de máquinas e equipamentos}

O setor de bens de capital é considerado amplo, complexo, heterogêneo e de difícil delimitação. De acordo com Alem e Pessoa (2005), os bens de capital reúnem bens extremamente distintos, como máquinas e equipamentos propriamente ditos, associados à indústria mecânica, máquinas elétricas, e, ônibus e caminhões, associados à indústria de material de transporte, conforme Figura 11. 
Segundo esses autores, pode-se classificar como bem de capital todo bem que for utilizado, como meio, em processos de produção de produtos ou serviços, sem que sofra transformação como os insumos.

Os bens de capital podem ser classificados, segundo seu processo produtivo, em bens seriados e bens sob encomenda. Os bens seriados são aqueles produzidos em larga escala, sem grandes especificidades do comprador. É dependente da escala de produção. Inserem-se nessa categoria as máquinas agrícolas, ônibus, caminhões e tratores.

Figura 11: Caracterização do setor de bens de capital

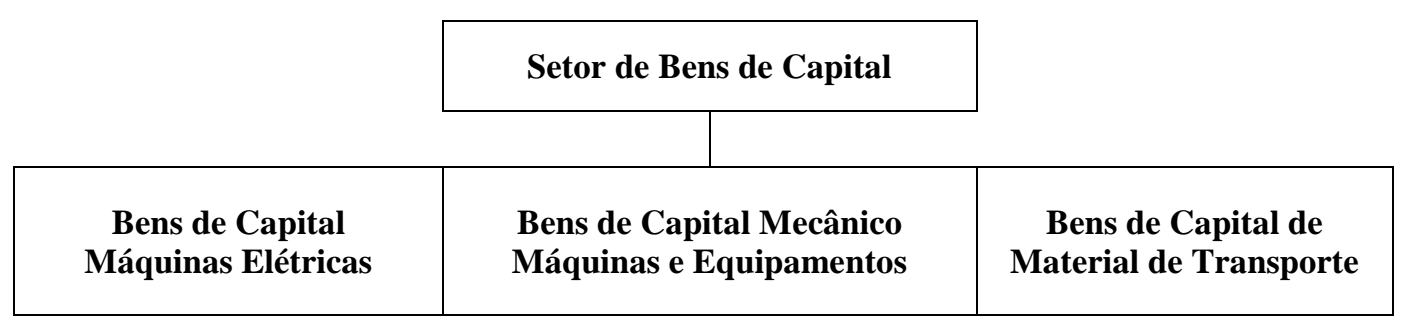

Fonte: Elaborado pelo autor a partir de Alem e Pessoa (2005)

Já os bens sob encomenda referem-se àqueles produzidos especialmente para um determinado comprador, segundo características técnicas associadas a determinado processo produtivo. São dependentes da tecnologia de produto e fortemente dos conhecimentos de engenharia de produto. Estão incluídas nessa categoria, as prensas utilizadas em montadoras de automóveis, turbinas de usinas hidroelétricas, plataformas de petróleo, e alto fornos para siderúrgicas.

Os fatores chave para a competitividade e o processo de acumulação de conhecimento nessas duas categorias são bem diferentes. De acordo com Araújo (2009), para os produtores de bens de capital seriados a escala de produção é importante, enquanto na produção de bens de capital sob encomenda, as economias dinâmicas, como o aprendizado, são fundamentais.

O conteúdo tecnológico dos produtos é o que determina a dinâmica dos segmentos. As barreiras à entrada, por exemplo, são mais frágeis no segmento de bens seriados com baixo conteúdo tecnológico. O mesmo não ocorre em segmentos dominados por empresas transnacionais, nos quais as barreiras à entrada são elevadas, onde a competitividade se dá, fundamentalmente, pelo grau elevado de desenvolvimento tecnológico e diferenciação de produto.

Considerando o papel que o progresso técnico desempenha no dinamismo da indústria de bens de capital e nos encadeamentos da indústria com o resto do sistema, é importante aplicar-se ao padrão de desenvolvimento tecnológico uma visão de cadeia produtiva. Conforme Vermulm e Erber (2002), a produção de bens pode ser considerada uma operação 
de montagem de componentes, onde parte dos quais pode ser fabricado pela própria empresa de bens de capital e outra parte, comprada de fornecedores especializados. Tais fornecedores, por sua vez, oferecem um conjunto amplo e diversificado de empresas pertencentes a diferentes setores de atividade, além da própria indústria de bens de capital. Logo, a existência de um conjunto de fornecedores especializados é um atributo sistêmico de grande importância para a competitividade da indústria. A proximidade geográfica entre fornecedores e compradores de componentes, oferecendo a oportunidade de troca de conhecimento tácito, é um elemento importante para o progresso técnico da indústria. Igualmente, ao interagir com as empresas que compram seus produtos, as empresas de bens de capital são estimuladas a introduzir inovações e, ao mesmo tempo, recebe informações que facilitam o processo de inovação.

Outro aspecto importante a ser destacado refere-se às características da estrutura da cadeia produtiva de bens de capital. De acordo com Vermulm e Erber (2002), apesar da reestruturação industrial, ocorrida na década de 1990, muitas empresas produtoras de bens de capital mecânicos ainda se encontram fortemente verticalizadas, principalmente através da integração com a fundição e da realização de serviços de usinagem internamente.

Além da verticalização das empresas, outra questão importante a ser destacada é a internacionalização das cadeias produtivas. Conforme Vermulm e Erber (2002), as principais motivações para a aquisição de componentes no mercado internacional, que se destacam são:

- Não existência de escala de produção para alguns componentes no Brasil;

- Prevalência de componentes mais sofisticados tecnologicamente demandados no mercado internacional;

- Componentes produzidos por empresas transnacionais que buscam tirar proveito $\mathrm{s}$ da especialização das suas plantas espalhadas pelo mundo, obrigando os produtores brasileiros a adquirirem-no mercado externo alguns d seus componentes porque as transnacionais não mais os fabricam no Brasil;

- Centralização de suprimentos de empresas transnacionais. A centralização dos suprimentos reduz o custo unitário adquirido em grandes lotes no mercado global.

Em função dessas razões, os elos das cadeias produtivas do setor de bens de capital encontram-se no exterior, e impactam diretamente sobre a competitividade dos produtores brasileiros. Para as empresas que importam seus insumos, os custos passam a depender das taxas de câmbio. Logo, flutuações na taxa de câmbio podem elevar os custos de produção e 
reduzir a competitividade dos produtos fabricados no Brasil. Outro efeito da internacionalização dos elos da cadeia é a necessidade de manter estoques. Normalmente, o tempo entre a encomenda e o recebimento para utilização no processo produtivo pode ser de meses, o que impõe às empresas uma manutenção de estoques nesse período.

De acordo com a Classificação Nacional de Atividades Econômicas - CNAE, o setor de máquinas e equipamentos, está representado na Seção C - Indústria de Transformação e Divisão 28. A Divisão 28, por sua vez, é composta por seis grupos:

- Grupo 28.1- Fabricação de motores, bombas, compressores e equipamentos de transmissão;

- Grupo 28.2 - Fabricação de máquinas e equipamentos de uso geral;

- Grupo 28.3 - Fabricação de tratores e de máquinas e equipamentos para a agricultura e pecuária;

- Grupo 28.4 - Fabricação de máquinas-ferramentas;

- Grupo 28.5 - Fabricação de máquinas e equipamentos de uso na extração mineral e construção;

- Grupo 28.6 - Fabricação de outras máquinas e equipamentos de uso específico.

Conforme Araújo (2009), o principal destino da produção de máquinas é o investimento das empresas, que compõe a Formação Bruta de Capital Fixo (FBCF) da economia. A FBCF mede o quanto as empresas aumentaram os seus bens de capital. Ele é importante porque indica se a capacidade de produção do país está crescendo. Aproximadamente $17 \%$ da FBCF brasileira é composta por máquinas e equipamentos, sendo que a participação nacional neste componente é de cerca de $80 \%$.

Dos setores que compõem a indústria de bens de capital, quatro em particular, representam cerca de $70 \%$ da formação bruta de capital fixo em máquinas e equipamentos: Grupo 281 Fabricação de motores, bombas, compressores e equipamentos de transmissão; Grupo 282 Fabricação de máquinas e equipamentos de uso geral; Grupo 284 - Fabricação de máquinasferramenta, e Grupo 286 - Fabricação de máquinas de uso específico. O presente estudo se apoia nos fabricantes de bens de capital mecânico pertencentes a esses quatro grupos.

Quanto aos insumos mais importantes do setor, eles podem ser representados em cinco grupos:

- Fabricação de aço e derivados; 
- Produtos de metal (exclusive máquinas e equipamentos);

- Metalurgia de metais não ferrosos;

- Refino de petróleo e coque;

- Plástico.

A seguir serão apresentadas as cadeias produtivas dos quatro principais setores de bens de capital, acima destacados.

Figura 12: Cadeia produtiva de motores, bombas, compressores e equipamentos de transmissão

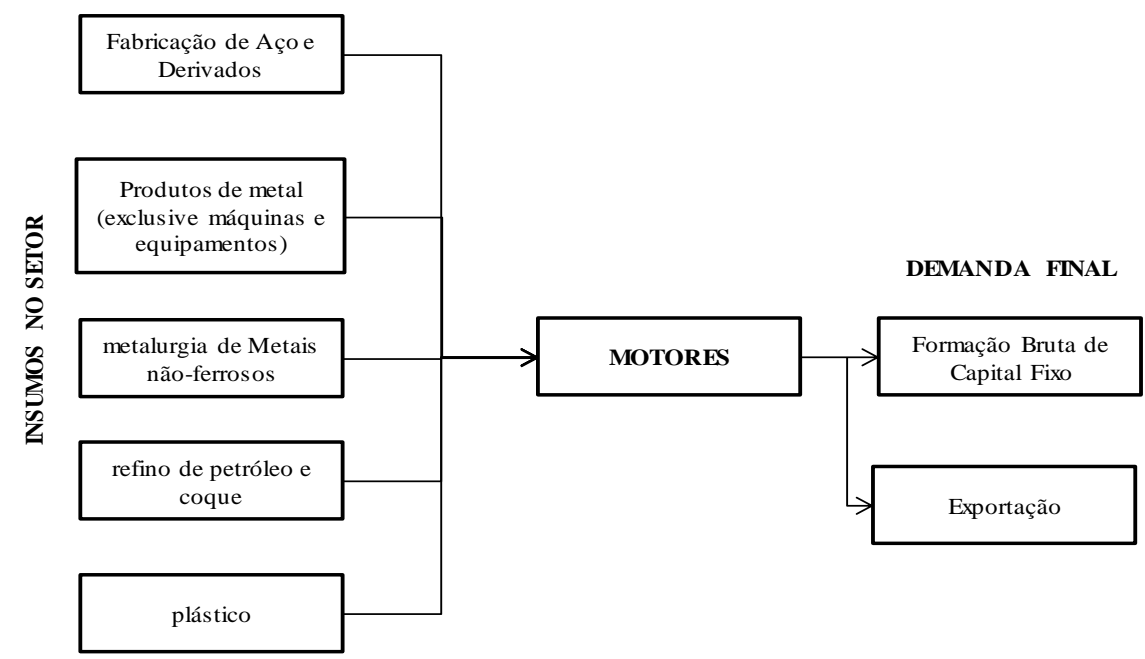

Fonte: Araújo (2009)

Figura 13: Cadeia produtiva de máquinas e equipamentos de uso geral

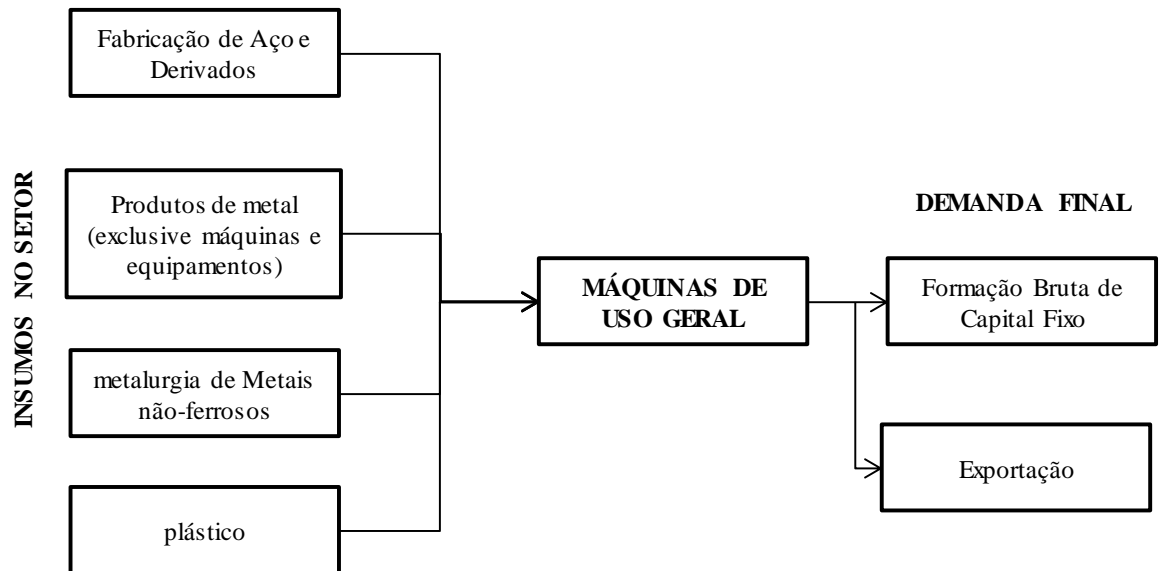

Fonte: Araújo (2009) 
Figura 14: Cadeia produtiva de máquinas-ferramentas

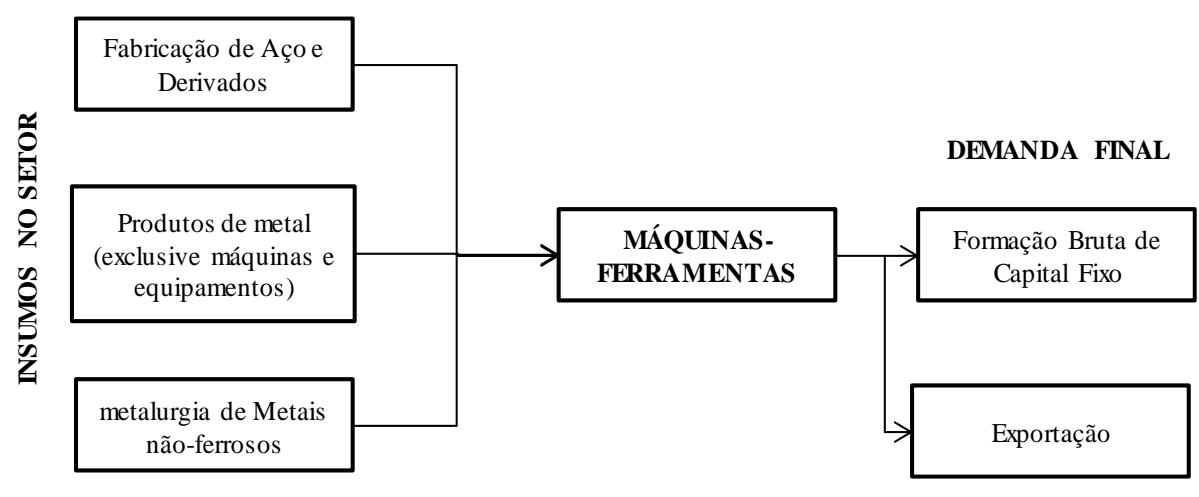

Fonte: Araújo (2009)

Figura 15: Cadeia produtiva de máquinas de uso específico

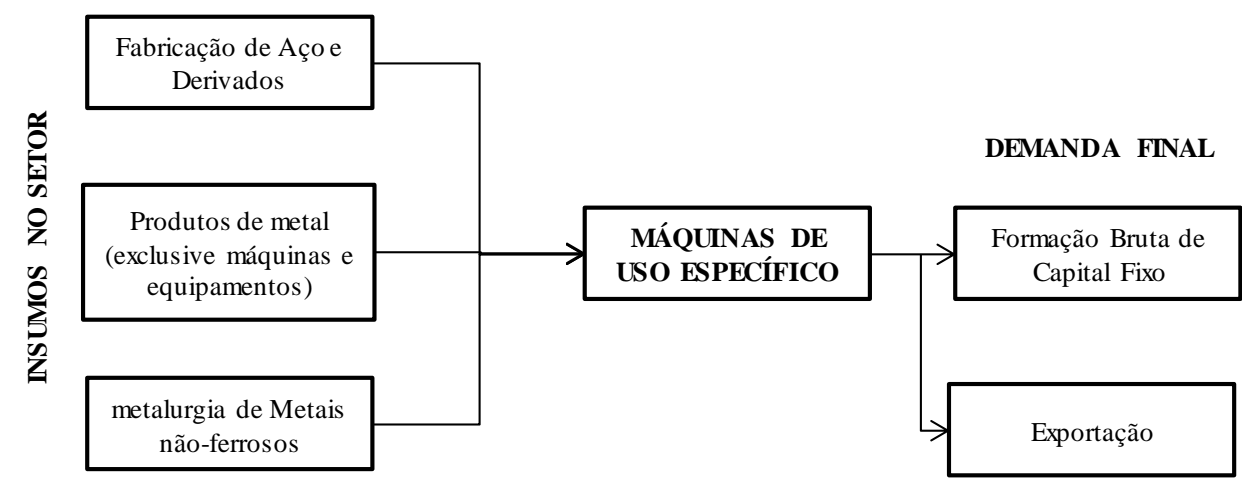

Fonte: Araújo (2009)

A demanda final, conforme mencionado anteriormente, tem seu destino final para formação bruta de capital fixo, seguida das exportações. Para os setores motores e máquinasferramentas as exportações apresentam uma importância maior quando comparados com outros dois. Nos dois primeiros setores, as exportações representam cerca de $50 \%$ das vendas para FBCF, e para os demais, apenas $20 \%$ do volume de vendas para FBCF.

Considerando os quatro setores destacados acima, juntos contam, em 2010, com aproximadamente 13,2 mil empresas (com mais de um empregado) e geram mais de 342 mil empregos diretos. Uma distribuição do número de empresas, por porte, e do pessoal ocupado, pode ser vista na Tabela 4 , abaixo. 
Tabela 4: Total de empresas e empregados no setor de bens de capital

\begin{tabular}{|c|c|c|c|c|c|c|}
\hline \multirow{2}{*}{$\begin{array}{c}\text { Porte } \\
\text { (Número de } \\
\text { funcionários) }\end{array}$} & \multicolumn{2}{|c|}{2000} & \multicolumn{2}{|c|}{2006} & \multicolumn{2}{|c|}{2010} \\
\hline & $\begin{array}{c}\text { Número de } \\
\text { empresas }\end{array}$ & $\begin{array}{l}\text { Número de } \\
\text { empregados }\end{array}$ & $\begin{array}{c}\text { Número de } \\
\text { empresas }\end{array}$ & $\begin{array}{l}\text { Número de } \\
\text { empregados }\end{array}$ & $\begin{array}{c}\text { Número de } \\
\text { empresas }\end{array}$ & $\begin{array}{l}\text { Número de } \\
\text { empregados }\end{array}$ \\
\hline 1 a 9 & 8.709 & 25.702 & 7.307 & 25.193 & 7.985 & 28.203 \\
\hline 10 a 49 & 2.775 & 57.950 & 3.553 & 73.436 & 4.053 & 85.431 \\
\hline 50 a 99 & 433 & 30.145 & 579 & 40.240 & 661 & 45.828 \\
\hline 100 a 249 & 271 & 41.189 & 317 & 48.254 & 368 & 57.603 \\
\hline 250 a 499 & 71 & 24.057 & 73 & 25.431 & 108 & 37.148 \\
\hline 500 ou mais & 51 & 69.625 & 50 & 59.900 & 63 & 88.024 \\
\hline Total & 12.310 & 248.668 & 11.879 & 272.454 & 13.238 & 342.237 \\
\hline
\end{tabular}

Fonte: IBGE/SIDRA - Cadastro central de empresas

Fundamentalmente, as empresas que compõem o setor são de micro e pequeno portes, representando $95,9 \%$ do total. As empresas de médio porte compõem a parcela de 3,6\% e as de grande porte, apenas 0,5\% aproximadamente, para o ano de 2010.

De Acordo com a Tabela 4 pode-se notar que entre o ano 2000 e 2010 houve um acréscimo de aproximadamente $7,5 \%$ no número de empresas, que, por sua vez, incrementaram em $38 \%$ o número de empregados.

Vale destacar que em 2006, com exceção do grupo de máquinas-ferramenta, ocorre um decréscimo no número de empresas, em relação ao ano de 2000. O aumento da população de empresas é retomado em 2010, conforme Gráfico 6.

Gráfico 6: Numero de empresas nos períodos de 2000, 2006 e 2010

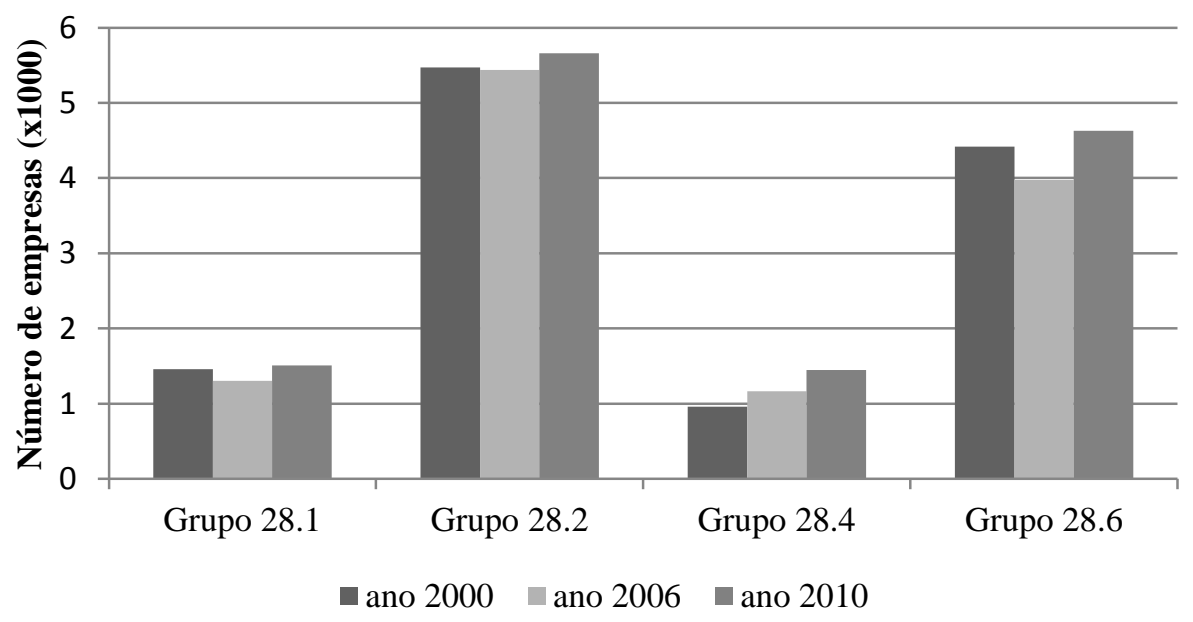

Fonte: Elabora pelo autor a partir de IBGE/SIDRA - Cadastro central de empresas 
O grupo que representa o subsetor de máquinas e equipamentos de uso geral é o que apresenta o maior número de empresas, com $43 \%$ do total, seguido pelo grupo de Outras máquinas e equipamentos de uso específico, com 35\%, pelos grupos de Motores, bombas, compressores e equipamentos de transmissão, e de máquinas-ferramenta, com aproximadamente $11 \%$ cada um, conforme Tabela 4.

No entanto, em relação ao número de empregados, o subsetor de motores, bombas, compressores e equipamentos de transmissão, embora compreenda aproximadamente o mesmo número de empresas que a do setor de máquinas-ferramenta, o número de empregados relacionado é 2,7 vezes maior (Gráfico 7).

Gráfico 7: Numero de empresas nos períodos de 2000, 2006 e 2010

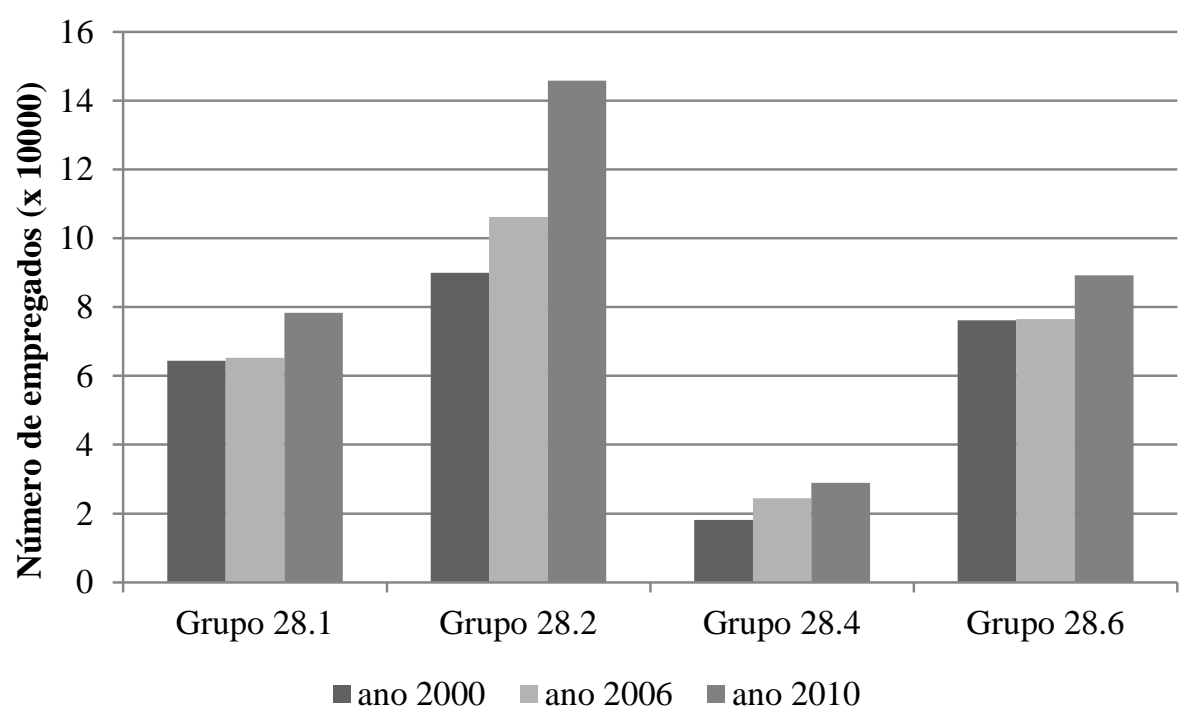

Fonte: Elabora pelo autor a partir de IBGE/SIDRA - Cadastro central de empresas

Uma distribuição mais detalhada, por subsetor, do número de empresas e número de pessoal ocupado pode ser vista na Tabela 5 abaixo:

O setor de bens de capital tem maior presença na região sudeste e sul do Brasil, e juntas compreendem aproximadamente $80 \%$ do emprego gerado pelo setor. Dentre os estados destacam-se São Paulo, com 46,7\% dos empregados, Rio Grande do Sul, com 12,9\% e Santa Catarina, com 8,6\% (RAIS, 2010) 
Tabela 5: Número de empresas e de empregados no setor de bens de capital

\begin{tabular}{|c|c|c|c|c|c|c|c|}
\hline \multirow{2}{*}{ Subsetor } & \multirow{2}{*}{ Porte } & \multicolumn{2}{|c|}{2000} & \multicolumn{2}{|c|}{2006} & \multicolumn{2}{|c|}{2010} \\
\hline & & $\begin{array}{c}\text { № de } \\
\text { empresas }\end{array}$ & $\begin{array}{c}\text { № de } \\
\text { empregados }\end{array}$ & $\begin{array}{c}\text { № de } \\
\text { empresas }\end{array}$ & $\begin{array}{c}\text { № de } \\
\text { empregados }\end{array}$ & $\begin{array}{c}\text { № de } \\
\text { empresas }\end{array}$ & $\begin{array}{c}\text { № de } \\
\text { empregados }\end{array}$ \\
\hline \multirow{7}{*}{$\begin{array}{c}28.1 \\
\text { Motores, } \\
\text { bombas, } \\
\text { compressores } \\
\text { e } \\
\text { equipamentos } \\
\text { de } \\
\text { transmissão }\end{array}$} & 1 a 9 & 934 & 2.697 & 619 & 2.240 & 722 & 2.664 \\
\hline & 10 a 49 & 335 & 7.632 & 444 & 9.970 & 517 & 11.640 \\
\hline & 50 a 99 & 87 & 6.031 & 110 & 7.957 & 127 & 8.866 \\
\hline & 100 a 249 & 61 & 9.478 & 92 & 13.593 & 85 & 13.976 \\
\hline & 250 a 499 & 24 & 8.544 & 23 & 8.179 & 34 & 11.553 \\
\hline & 500 ou mais & 20 & 30.066 & 18 & 23.337 & 23 & 29.586 \\
\hline & Total & 1.461 & 64.448 & 1.306 & 65.276 & 1.508 & 78.285 \\
\hline \multirow{7}{*}{$\begin{array}{l}28.2 \\
\text { Máquinas e } \\
\text { equipamentos } \\
\text { de uso geral }\end{array}$} & 1 a 9 & 3.986 & 11.712 & 3.479 & 11.752 & 3.391 & 11.919 \\
\hline & 10 a 49 & 1.184 & 24.471 & 1.548 & 31.173 & 1.751 & 36.535 \\
\hline & 50 a 99 & 165 & 11.512 & 235 & 16.255 & 280 & 19.508 \\
\hline & 100 a 249 & 98 & 14.410 & 126 & 19.502 & 159 & 25.087 \\
\hline & 250 a 499 & 25 & 8.379 & 30 & 10.645 & 51 & 17.458 \\
\hline & 500 ou mais & 14 & 19.466 & 17 & 16.884 & 26 & 35.256 \\
\hline & Total & 5.472 & 89.950 & 5.435 & 106.211 & 5.658 & 145.763 \\
\hline \multirow{7}{*}{$\begin{array}{c}28.4 \\
\text { Máquinas- } \\
\text { ferramenta }\end{array}$} & 1 a 9 & 671 & 1.915 & 723 & 2.419 & 920 & 3.127 \\
\hline & 10 a 49 & 217 & 4.526 & 348 & 7.574 & 419 & 8.838 \\
\hline & 50 a 99 & 40 & 2.758 & 62 & 4.201 & 64 & 4.598 \\
\hline & 100 a 249 & 19 & 3.130 & 27 & 4.426 & 35 & 5.292 \\
\hline & 250 a 499 & 6 & 1.932 & 2 & 598 & 4 & 1.381 \\
\hline & 500 ou mais & 4 & 3.818 & 4 & 5.201 & 4 & 5.685 \\
\hline & Total & 957 & 18.079 & 1.166 & 24.429 & 1.446 & 28.921 \\
\hline \multirow{7}{*}{$\begin{array}{c}28.6 \\
\text { Outras } \\
\text { máquinas e } \\
\text { equipamentos } \\
\text { de uso } \\
\text { específico }\end{array}$} & 1 a 9 & 3.118 & 9.378 & 2.486 & 8.782 & 2.952 & 10.493 \\
\hline & 10 a 49 & 1.039 & 21.321 & 1.213 & 24.719 & 1.366 & 28.418 \\
\hline & 50 a 99 & 141 & 9.844 & 172 & 11.827 & 190 & 12.856 \\
\hline & 100 a 249 & 93 & 14.171 & 72 & 10.733 & 89 & 13.248 \\
\hline & 250 a 499 & 16 & 5.202 & 18 & 5.999 & 19 & 6.756 \\
\hline & 500 ou mais & 13 & 16.275 & 11 & 14.478 & 10 & 17.497 \\
\hline & Total & 4.420 & 76.191 & 3.972 & 76.538 & 4.626 & 89.268 \\
\hline
\end{tabular}




\subsection{Síntese do desempenho da indústria de bens de capital no Brasil}

A indústria de bens de capital no Brasil tem seguido uma trajetória de crescimento irregular, caracterizada por constantes crises e retomadas. As décadas de 1950 e 1970 representaram períodos importantes de construção e evolução da indústria de bens de capital no Brasil. O Plano de Metas (1956-1961) e o II Plano de Desenvolvimento Nacional (1974-1979) foram marcados por políticas de substituição de importações, investimentos maiores na indústria, elevadas taxas de crescimento, e certo amadurecimento tecnológico. Houve ampliação da capacidade produtiva e da participação da produção local na oferta total. Apesar de ter sido um período considerado favorável à indústria de bens de capital vale destacar fases distintas, de retração e expansão do setor. As importações foram significativas no período, enquanto as exportações pouco representativas. A atuação do Estado representou um importante fator de incentivo, diversificação e consolidação do setor. A década de 1970 foi muito importante para a expansão e consolidação do setor de bens de capital no Brasil.

Na década de 1980, a indústria de bens de capital passou por uma fase de instabilidade que seguiu o próprio comportamento da economia brasileira. A instabilidade econômica reduziu os investimentos públicos e o processo de industrialização por substituição de importações chegou ao fim, já que não era mais visto como fonte de crescimento da produção industrial. O processo de industrialização por substituição de importações, apesar de ter sido importante para a industrialização brasileira, não resultou em desenvolvimento de produtos de maior conteúdo tecnológico, e ao longo dos anos o setor apresentou dificuldade de inserção no mercado externo. O atraso tecnológico gerado caracterizou uma indústria de bens de capital com baixa competitividade e pequena participação no total da economia. A crise econômica desse período limitou a demanda por bens de capital e inibiu a introdução de inovações apropriadas para acompanhar a dinâmica tecnológica que ocorria nos países que detinham os avanços do setor. Em outros termos, a ausência de desenvolvimento de produtos resultou num aumento da defasagem tecnológica na indústria brasileira de bens de capital.

A década de 1990 é marcada pela instabilidade macroeconômica e pela liberalização comercial brasileira. Ocorre uma retração no mercado interno, que combinado com a sobrevalorização da moeda brasileira, favorece a expansão do coeficiente de importação, com substituição de máquinas nacionais por estrangeiras. Há uma expansão de produtos e componentes estrangeiros no mercado interno, e na participação de empresas transnacionais, que lideram a produção de nos diversos segmentos da indústria de bens de capital no Brasil. 
Do ponto de vista estrutural, cresce a internacionalização da cadeia produtiva. A dificuldade de obtenção de escala produtiva para alguns componentes no Brasil e a prevalência de componentes mais sofisticados tecnologicamente no exterior, impactam sobre a competitividade dos produtores brasileiros, que passam a depender e condicionar seus cistos ao comportamento da taxa de câmbio.

Em termos gerais, a indústria de bens de capital nesse período, apresenta baixos níveis de competitividade, esforços de desenvolvimento tecnológicos limitados e investimentos em modernização do processo produtivo reduzidos.

Nos anos 2000, o desempenho da indústria de bens de capital se encontra novamente atrelado ao ciclo de investimentos da economia. No início da década tem-se uma nova retomada, impulsionada pelo crescimento econômico, seguida de outra retração, no final da década, em função da crise financeira internacional. De maneira geral, há um crescimento substancial da produção física, com pequenas oscilações, interrompido, em 2009, pela crise internacional. Tem-se um aumento do consumo aparente, porém acompanhado de um aumento também das importações. Ao longo da década de 2000 verifica-se uma mudança ampla na origem das importações, com presença intensa e crescente da China. O aumento das importações, em especial da China, não decorre da ausência de capacidade física, mas da baixa competitividade que as empresas brasileiras apresentam no padrão de concorrência via preço.

O setor de bens de capital no Brasil apresenta boa capacidade de produção, mas certa defasagem tecnológica. Por outro lado, o setor possui uma estrutura diversificada e consolidada. Embora apresente algumas limitações em termos de competitividade, há uma experiência acumulada no setor e um mercado interno amplo para viabilizar economias de escala. Sendo assim, vale destacar a importância de se investir e incentivar o setor. Tais ações se justificam, conforme destacado por Nassif e Ferreira (2010), pelo fato de o setor brasileiro apresentar uma enorme potencial de incremento da demanda, e deter, conforme já frisado, um elevado potencial gerador e difusor de inovações, capaz de auxiliar o ritmo de crescimento da produtividade na economia como um todo.

\subsection{Dinâmica do setor de bens de capital}

O setor de bens de capital abrange um conjunto muito heterogêneo de produtos. A heterogeneidade desta indústria, conforme Vermulm (2003), pode ser entendida sob diversas dimensões. No nível do produto, a heterogeneidade é uma das principais características da indústria de bens de capital. Por exemplo, no segmento de máquinas-ferramenta coexistem 
mais de 3000 tipos. Os produtos podem se diferenciar entre si segundo a finalidade a que se destinam, meios de controle, desempenho e acessórios. Deste modo, cada tipo de indústria usuária demanda um produto diferente e específico, ou seja, existem máquinas para embalagens, máquinas e implementos para a agricultura, máquinas-ferramenta, máquinas para indústria têxtil, etc.

As máquinas também se diferenciam pelo tipo de trabalho que realizam (torneamento, retífica, etc) mesmo que para um usuário específico, pelo desempenho, flexibilidade, produtividade, precisão, preço, sofisticação tecnológica, entre outros. Em outros termos, existem produtos que seguem diferentes paradigmas tecnológicos, que compreendem máquinas eletromecânicas e máquinas de comando computadorizado.

A heterogeneidade de usos a que se destinam os bens de capital, de acordo com Vermulm e Erber (2002), implica a coexistência, em um mesmo espaço social de produtos, de várias gerações tecnológicas. Nesse sentido, as empresas para serem competitivas precisam possuir não apenas instalações, máquinas e mão-de-obra adequadas, mas competências específicas em engenharia de projeto e produto, comercialização e serviços de assistência técnica pós-venda.

As competências e recursos para a comercialização e serviços pós-venda são cruciais para a competitividade das empresas de bens de capital, em especial, para os bens fabricados sob encomenda, onde os serviços de venda e assistência posterior são feitos com forte envolvimento direto do fabricante.

É importante destacar que dentre os segmentos de mercado em que atuam as empresas, o mix competitivo varia de acordo com a maturidade tecnológica do produto. Essa característica, por sua vez, exprime as características dos compradores dos bens de capital. Empresas que fornecem produtos a consumidores que demandam bens no "estado da arte" precisam de grande competência em engenharia de produto e fortes vínculos com o sistema científico e tecnológico. Por outro lado, para produtos maduros a engenharia de produto, mesmo que fundamental, é menos vinculada ao sistema científico e tecnológico e, faz uso mais intenso da engenharia reversa.

Outra implicação relevante refere-se ao preço. Em muitas empresas, nacionais ou estrangeiras, para produtos padronizados ou fornecidos a consumidores menos exigentes, do ponto de vista tecnológico, o preço é uma variável mais importante na competição e a empresa precisa desenvolver mais competências para adaptar o projeto com foco na redução de custos e na capacidade para introduzir inovações de processo, atuar junto a fornecedores 
mais eficientes que possam oferecer suprimentos com custo menor, e estabelecer canais de comercialização e serviços pós-vendas com baixo custo (VERMULM e ERBER, 2002).

Vale destacar ainda, a importância dos fatores sistêmicos na definição e viabilização das competências necessárias à sobrevivência e crescimento das empresas do setor de bens de capital. Em outros termos, é a estrutura produtiva, a dimensão e o dinamismo do mercado que estabelecem as características dos bens de capital demandados, o que por sua vez, depende dos condicionantes derivados da política macroeconômica adotada pelo país. Por outro lado, há outros fatores tais como a disponibilidade de insumos, mão-de-obra, componentes, recursos técnico-científicos e condições financeiras que condicionam o que pode ser projetado e fabricado pelas empresas.

A heterogeneidade também é observada no que se refere à estrutura das empresas produtoras de bens de capital. Os segmentos compreendem desde empresas familiares, de pequeno e médio portes, à grande grupos empresariais, normalmente de origem e capital estrangeiro. A heterogeneidade dos produtos gera, por sua vez, um grande número de nichos de mercado. Para os produtos de conteúdo tecnológico mais simples há uma produção bastante difusa internacionalmente, e as barreiras à entrada, por sua vez, são relativamente baixas.

Por outro lado, em relação aos produtos mais complexos e de maior conteúdo tecnológico, a produção concentra-se mais em países desenvolvidos como EUA, Alemanha, Itália, e Japão, e demanda condições sistêmicas diferenciadas.

De acordo com a Classificação Nacional de Atividades Econômicas - CNAE, o setor de bens de capital, composto pelos grupos (i) fabricação de motores, bombas, compressores e equipamentos de transmissão; (ii) fabricação de máquinas e equipamentos de uso geral; (iii) fabricação de máquinas-ferramentas; (iv) fabricação de outras máquinas e equipamentos de uso específico, apresenta vários segmentos produtores, conforme mostrado abaixo. Um detalhamento maior dos segmentos produtores pode ser visto no Anexo 1.

\subsection{Políticas tecnológicas para a indústria de bens e capital}

A indústria de bens de capital possui um papel central no processo de difusão tecnológica nos mais diversos setores da economia. Encontra-se em uma aposição singular no sistema produtivo para a realização de inovações técnicas, já que é por meio dela que a introdução do progresso técnico se faz presente no sistema industrial como um todo. No entanto, é fato que historicamente, o Brasil pouco participa das inovações significativas, em especial, no setor 
mecânico. Ao longo do tempo, a indústria brasileira de bens de capital tem apresentado uma defasagem tecnológica em relação aos países desenvolvidos.

A incorporação de novas tecnologias, no início do processo de industrialização brasileira, ocorreu fundamentalmente por meio das importações. Entretanto, De acordo com Tironi (1979), as importações, embora propiciem oportunidade de transferência tecnológica, podem representar também um fator inibidor para o cumprimento do papel difusor de tecnologia por toda a economia, que deveria desempenhar o setor de bens de capital, nos casos em que a oferta doméstica não tenha acesso a inovações que poderiam ser difundidas por meio de seus produtos.

Conforme já mencionado, o setor de bens de capital foi introduzido no Brasil na década de 1950 pelo Plano de Metas do governo de Juscelino Kubitschek (1956-61). No entanto, o Plano de Metas se limitou à instalação de indústrias produtoras, e não determinou a formação de contingente técnico para o sistema produtivo em desenvolvimento.

Somente a partir de 1968 é que os planos de governo incluíram explicitamente a importância do desenvolvimento tecnológico como desenvolvimento econômico. Por meio do Programa Estratégico de Desenvolvimento (PED) a tecnologia assume um papel de destaque, passando a ser considerada como elemento básico no processo de desenvolvimento. O PED visava a renovação dos setores dinâmicos, a consolidação da infraestrutura, o incentivo a programas de expansão do poder de demanda, e a recuperação do atraso tecnológico (MATOS, 2002).

Entendia-se, conforme destacado em Tironi (1979), que a tecnologia importada nem sempre é adequada ao conjunto de fatores do país importador e que a própria absorção de tecnologia requer, na medida em que a indústria se integra, pesquisa e desenvolvimento locais. Reconhecia-se também o papel do Estado como principal orientador e financiador do esforço de pesquisa e que as empresas estrangeiras concentravam o desenvolvimento de suas pesquisas em suas matrizes.

Em 1969 foi criado o Conselho de Desenvolvimento Industrial (CDI), com o objetivo de estabelecer diretrizes da política de desenvolvimento industrial. No entanto, as ações administradas pelo CDI não foram eficientes e estimulantes para a produção interna de bens de capital, já que os benefícios eram concedidos somente no caso de importação dos bens de capital.

Entre 1970 e 1971, passou a vigorar o plano subsequente, denominado Metas e Bases para a Ação do Governo. Do ponto de vista tecnológico, o documento, fundamentalmente, foi uma 
extensão das disposições contidas no PED, que buscava adaptação da tecnologia importada às condições nacionais. O plano estabeleceu como prioridade nacional, entre outros, investimentos em educação e avanço no desenvolvimento científico e tecnológico.

O CDI passou por uma reorganização e a política de incentivos ao desenvolvimento industrial foi reformulada, e o órgão, com alcance maior, tornou-se responsável pela política de desenvolvimento industrial. Dentre as principais medidas de política, destacam-se a isenção do imposto de importação e a isenção do imposto sobre produtos industrializados para a importação de bens de capital.

Em 1972 tem-se o I Plano Nacional de Desenvolvimento (PND I), o qual, através do documento I Plano Básico de Desenvolvimento Científico e Tecnológico (I PBDCT), explicita a política tecnológica. Sua estratégia apoia-se em três princípios, conforme mencionado em Tironi (1979): (i) fortalecer o poder de competição da indústria nacional, visando um nível de competitividade internacional; (ii) fortalecer a empresa privada nacional; e (iii) acentuar o papel da indústria como instrumento de transformação tecnológica dos demais setores. Dentre as medidas para o alcance dos objetivos, tem-se a fixação dos índices de nacionalização. Vale destacar que a política tecnológica estabelecida pelo PND I difere da política do PED pela primeira priorizar a competitividade da indústria nacional.

Em 1974 novos mecanismos de fortalecimento da empresa nacional foram estabelecidos, dentre os quais se destacam a Investimentos Brasileiros S.A. (IBRASA); Financiamento de Insumos Básicos (FIBASE); Mecânica Brasileira S.A. (EMBRAMEC), todas subsidiadas pelo BNDE - Banco Nacional de Desenvolvimento Econômico, atual BNDES - Banco Nacional de Desenvolvimento Econômico e Social.

Entre 1975 e 1979 foi elaborado o II Plano Nacional de Desenvolvimento (PND II), e dentre outros, tinha como objetivo a substituição de importações nos setores de bens de capital e de insumos básicos, e a ampliação do desenvolvimento científico nacional (CAVARZAN e RACY, 2008). O PND II apontou o setor de bens de capital como um dos setores prioritários para fins de política industrial e foi beneficiado com vários incentivos públicos voltados para a sua promoção. De acordo com Nassif (2007), os mais importantes incentivos foram:

(i) A prioridade que passou a ser dos produtos nacionais nas compras realizadas pelas empresas estatais; 
(ii) Maior exigência nos critérios para exame de existência de similar nacional, cuja comprovação era condição para que as empresas interessadas obtivessem reduções ou isenções fiscais e tributárias na importação de produtos supostamente concorrentes;

(iii) Acordos de participação nacional que induziam à compra de equipamentos domésticos nos grandes projetos de investimento realizados pelo setor privado;

(iv)As exigências de índices crescentes de nacionalização para fins de acesso a créditos subsidiados pela Financiadora de Máquinas e Equipamentos - FINAME/BNDES;

(v) O Programa Befiex, que isentava da cobrança de impostos de importação de bens de capital as empresas que se comprometesses com valores expressivos de exportação futuros.

É importante destacar, conforme Tironi (1979), que essa política de incentivar a produção completa das máquinas no Brasil, apresenta uma nova visão, com dinamização da economia, a partir da substituição de importações. No entanto, conforme Nassif (2007), apesar dos incentivos públicos, poucos foram os avanços na convergência tecnológica e nos níveis de eficiência econômica para o "estado da arte" no mercado mundial. Dentre os vários fatores que contribuíram para esse baixo desempenho, dois se destacam. $\mathrm{O}$ primeiro refere-se à estratégia de absorção de tecnologia. Neste caso, os contratos de licenciamento, de maneira geral, não permitiam a possibilidade de exportação de produtos brasileiros para os países inovadores. Como consequência, segmentos intensivos em escala, operaram muito aquém da escala mínima eficiente, além de ver aumentado o tempo de suas curvas de aprendizado. Um segundo fator, diz respeito à forte proteção da indústria. Como efeito, as barreiras para importação estimularam as empresas produtoras no Brasil a um excessivo processo de verticalização de sua produção.

A década de 1980 foi caracterizada por indicadores macroeconômicos desfavoráveis em quase todo seu período. As elevadas taxas de inflação, escassez cambial e dificuldades de acesso a crédito externo, contribuíram fortemente para a baixa competitividade da indústria de bens de capital, com expressiva retração da demanda.

Vale destacar, de acordo com Viotti (2008), que a política de ciência e tecnologia manteve a tradição de promoção das atividades de Pesquisa e Desenvolvimento (P\&D). Entretanto, a crise fiscal, que se prolongou no período, e a associada visão de curto prazo, que predominava na gestão das políticas públicas, determinou a redução do apoio às atividades e instituições de P\&D ao longo da década de 1980. 
Apesar de a política industrial, do PND II, proteger e oferecer subsídios públicos para promover a produção local, os incentivos fiscais e tributários para aquisições de bens de capital externo prevaleceram, e a demanda cresceu de forma complementar à produção interna (NASSIF, 2007). O rompimento da excessiva proteção da indústria doméstica só ocorreu na década seguinte, a de 1990, quando do processo de abertura econômica brasileira.

A abertura do comércio internacional, de acordo com Viotti (2008), passa a ser considerada como crucial para o desenvolvimento, assumindo desta forma, o lugar que o processo de industrialização ocupava anteriormente. A abertura do mercado interno para produtos era vista como principal instrumento da política de ciência e tecnologia implícita no modelo de desenvolvimento. $\mathrm{O}$ objetivo era que com a abertura as empresas, em função das pressões competitivas, introduzissem inovações tecnológicas, e que se facilitasse e se acelerasse processo de transferência de tecnologias estrangeiras para o país por meio de investimentos diretos estrangeiros. Todavia, a liberalização comercial reduziu as barreiras à importação e a indústria brasileira de bens de capital, devido a um elevado nível de desvantagem comparativa, foi uma das mais afetadas negativamente. De acordo com Moreira e Correa (1997), o segmento de máquinas e equipamentos foi um dos mais prejudicados pela maior concorrência com os importados entre 1990 e 1995. Os baixos níveis de eficiência e competitividade, e atraso tecnológico, foram relacionados às políticas de industrialização adotadas nos períodos anteriores.

Conforme Nassif (2007), em especial, no que se refere ao setor de bens de capital, o aumento da competição externa gerou uma modificação da estrutura produtiva, dentre as quais se destacam:

- Um intenso movimento de saída de empresas ineficientes da indústria;

- O aumento da participação de empresas estrangeiras no setor;

- A redução expressiva do número de bens produzidos por empresa; e

- A desverticalização dos processos de bens produção preexistentes.

Diante disso, com o objetivo de reestruturar a potencialidade da indústria, a política econômica passou a priorizar a busca pela eficiência. Com efeito, o período foi marcado por privatizações, desregulamentações, redução ou exclusão de subsídios e de barreiras tarifárias e não tarifárias ao comércio internacional, câmbio livre e livre movimentação de capitais estrangeiros. 
Apesar das dificuldades, em especial orçamentárias, encontradas na década de 1990, a formação de recursos humanos para pesquisa apresentou significativo avanço. Houve um crescimento importante da pós-graduação e sua consolidação no período. Em 1987 havia 3647 mestres e 868 doutores no Brasil, e, no ano de 2000, o número de titulados era de 18373 mestres e 5335 doutores, conforme dados da agência de fomento à pesquisa CAPES Coordenação de Aperfeiçoamento de Pessoal de Nível Superior.

Outros avanços importantes da política de ciência e tecnologia ocorreram nesse período, conforme destacado em Viotti (2008):

- Qualidade e expansão da educação. Reconheceu-se a lacuna e a importância de uma mãode-obra mais qualificada para a elevação da capacitação tecnológica das empresas brasileiras;

- Reforma do regime de propriedade intelectual. A reforma tinha por objetivo principal reduzir natureza de bem público do conhecimento científico e tecnológico, permitindo o seu emprego simultâneo por diversos usuários. Buscava-se promover a inovação nas empresas instaladas no Brasil, independentemente da origem de seu capital;

- Difusão do uso de práticas de gestão da qualidade. Ocorreu um processo acelerado de práticas de gestão da qualidade estimulado pelo Programa Brasileiro de Qualidade e Produtividade (PBQP), criado em 1990. Buscava-se, a partir dos programas de qualidade a elevação da competitividade com redução dos custos;

- Promoção do empreendedorismo e das incubadoras e parques tecnológicos. Buscava-se fortalecer o ambiente para a inovação e promover a criação de pequenas empresas de base tecnológica, contribuindo, mesmo que de maneira marginal, para a elevação dos padrões tecnológicos pré-existentes;

- Introdução da inovação como um objetivo da política. Estimulada pela liberação de mercado, a inovação passou a ganhar espaço e importância nas políticas de Ciência e Tecnologia. Passou a ser incluída nas políticas de desenvolvimento regional, estadual e municipal.

Apesar do reconhecimento e do esforço das políticas para promoção da eficiência e inovação nas empresas brasileiras, sua efetiva introdução na prática não ocorreu como esperado. Houve um entendimento, de certa forma simplista, de que a educação seria um requisito suficiente para o desenvolvimento, desconsiderando outros fatores. A reforma do regime de propriedade intelectual favoreceu muito mais as empresas estrangeiras do que as nacionais. A gestão da 
qualidade no Brasil, inserida em um contexto macroeconômico com baixo crescimento da demanda, grande escassez de crédito e forte pressão competitiva, foi adotada como uma estratégia defensiva suficiente para maior competitividade, ignorando a necessidade de realização de novos investimentos.

Vale destacar, no entanto, os avanços importantes dos programas e ações públicas para a promoção de incubadoras e parques tecnológicos. Houve um crescimento significativo na década, passando de duas incubadoras em 1988, para 150, no ano de 2000, conforme dados da Anprotec - Associação Nacional de Entidades Promotoras de Empreendimentos Inovadores.

Em resumo, conforme enfatizado em Viotti (2008), a abertura comercial brasileira não trouxe o crescimento da economia substancial. A forte elevação das pressões competitivas, a abertura para os investimentos estrangeiros no Brasil e o fortalecimento da propriedade intelectual não demonstraram capacidade de estimular o desenvolvimento de uma dinâmica significativa de inovação nas empresas.

\subsection{Década de 2000 em diante: articulação entre política tecnológica e política industrial}

A partir da década de 2000, uma nova fase de políticas para o desenvolvimento se inicia. Além das políticas sociais, observa-se uma revalorização geral das políticas públicas. Houve um entendimento de que o processo de inovação nas empresas não poderia ocorrer apenas pelo simples processo de abertura comercial, pelo fortalecimento da propriedade intelectual e aumento dos investimentos estrangeiros. Uma nova política industrial e de ciência e tecnologia passou a ser debatida e um conjunto de importante de medidas foi instituído no início dessa nova fase. Vale lembrar, conforme destacado em Lall (2013), que as intervenções do Estado são fundamentais para determinar a estrutura e a capacitação tecnológica da indústria. Elas são necessárias para superar falhas de mercado na construção das capacidades necessárias para o desenvolvimento industrial. O Estado, nesse sentido, pode impulsionar sua indústria a competir em setores de maior conteúdo tecnológico, promover um maior ciclo de aprendizagem e possibilitar a ampliação do mercado e geração de externalidades.

Dentre as principais medidas, destacam-se a criação de Fundos Setoriais de Apoio ao Desenvolvimento Científico e Tecnológico, a Lei de Inovação, a Lei do Bem e a Política Industrial, Tecnológica e de Comércio Exterior, a PITCE. Vale ressaltar, conforme Viotti (2008), que a PITCE reabilitou as políticas industriais, que tinham sido banidas na fase 
anterior do desenvolvimento brasileiro, e que pela primeira vez, no Brasil, se buscou de maneira explícita a articulação entre política industrial com a política tecnológica.

A criação dos Fundos Setoriais buscou garantir a ampliação e a estabilidade dos recursos destinados ao desenvolvimento de ciência, tecnologia e inovação no Brasil. A lei de inovação, por sua vez, concentra-se no objetivo de promover a contribuição de universidades e institutos de pesquisa públicos para o processo de inovação. Para isso, a lei regula a transferência para as empresas privadas de tecnologias geradas pelas instituições; e possibilita o compartilhamento das infraestruturas, equipamentos e recursos de pessoal.

A lei do Bem buscou não apenas ampliar os incentivos fiscais, já existentes, mas determinou outros incentivos para as empresas que realizam atividades de Pesquisa, Desenvolvimento e Inovação Tecnológica (PD\&I). São concedidas subvenções econômicas para empresas que contratarem pesquisadores com título de mestrado ou doutorado para a realização de atividades PD\&I. Outra importante atuação da lei está na concessão de recursos financeiros subvencionados para as empresas e financiamento de produtos e processos inovadores.

Em relação à PITCE, lançada em 2003, suas diretrizes tinham como objetivo (i) o aumento da eficiência da estrutura produtiva; (ii) o aumento da capacidade de inovação das empresas brasileiras; e (iii) a expansão das exportações.

A PITCE foi organizada em três grandes planos:

a) Linhas de ação horizontal;

b) Opções estratégicas; e

c) Atividades portadoras de futuro.

Dentre as linhas de ação horizontal concentram-se ações voltadas para inovação e desenvolvimento tecnológico; inserção externa; modernização industrial; ambiente institucional; e aumento da capacidade produtiva.

O plano voltado para a inovação e desenvolvimento tecnológico tem como objetivo desenvolver a competitividade das empresas, com maior inserção no mercado internacional, apoiando-se, sobretudo, nas Parcerias Público-Privadas (PPP). A Lei da Inovação representa um desses mecanismos, que procura estimular as parcerias entre o meio acadêmico e a iniciativa privada. Quanto à inserção externa, as ações estão direcionadas para a inclusão da indústria brasileira nos padrões internacionais de concorrência. Diversas medidas fiscais e de 
acesso a crédito foram estabelecidas. Dentre os programas relacionados a essa linha de ação destacam-se:

- Programa Brasil Exportador. Estabelece a suspensão ou isenção de imposto para as matérias-primas importadas, desde que direcionadas para a produção de bens para a exportação;

- Sistema Radar Comercial: voltado para a prospecção de negócios no exterior;

- Nova Cofins: elimina a cumulatividade da contribuição e estabelece cobrança para os importados, criando isonomia com as mercadorias nacionais; e

- Centros de Distribuição e Logística no Exterior.

Quanto à modernização industrial, vale destacar a criação do Programa de Modernização do Parque Industrial Nacional - Modermaq. O objetivo deste programa é o de financiar máquinas e equipamentos nacionais novos, com taxas reduzidas, em especial, para as empresas de pequeno porte.

Por fim, o ambiente constitucional, destinado para a criação de condições de infraestrutura, condições tributárias e fiscais. Para essa linha de ação horizontal, foram criados o Conselho Nacional de Desenvolvimento Industrial - CNDI, e a Agência Brasileira de Desenvolvimento Industrial - ABDI. Vale destacar as ações voltadas para a redução e atração de novos investimentos. Em especial, para o setor de bens de capital, podemos citar a desoneração do Imposto sobre Produtos Industrializados (IPI). É importante salientar, conforme Castilhos (2005), que além de as novas condições institucionais favorecerem nitidamente as empresas exportadoras, ou potencialmente exportadoras, as medidas buscam amenizar os efeitos da política de juros altos para os segmentos e as empresas a serem incentivados.

No que se refere ao plano das opções estratégicas, o objetivo é de promover o desenvolvimento de setores, que de acordo com a PITCE, caracterizam-se pelo seu dinamismo crescente; por representarem importantes investimentos internacionais em $\mathrm{P} \& \mathrm{D}$; por gerarem novas oportunidades de negócios. Dentre os citados, destaca-se o setor de bens de capital, cujas ações buscam o incentivo à produção e à aquisição. Para tal, tem-se incluído o programa de financiamento BNDES, destinado a compradores e fabricantes. Além do setor de bens de capital, estão inseridos os setores de semicondutores; softwares; fármacos e medicamentos. Esses setores se ressaltam por permitirem inovações de produto e processos, contribuírem para o adensamento do tecido produtivo, e possuírem potencial para o desenvolvimento de vantagens comparativas dinâmicas (CASTILHOS, 2005). 
Finalmente, as atividades portadoras de futuro referem-se a setores ainda incipientes no Brasil, mas que são considerados estratégicos para desenvolvimento futuro da economia. Os setores relacionados são nanotecnologia, biotecnologia e materiais avançados, entre outros. Vale destacar, no entanto, que por se tratar de setores incipientes as atividades e iniciativas das empresas para pesquisas ainda são pequenas e enfrentam vários obstáculos para seu desenvolvimento.

Em síntese, conforme Viotti (2008), a PITCE com características de uma política que procura ser simultaneamente industrial e tecnológica sinaliza um deslocamento do eixo da política de CT\&I na direção de uma aproximação das empresas e do setor produtivo. O uso das políticas de CT\&I como instrumento de desenvolvimento regional e local confere à inovação um papel importante, que se alinha aos sistemas nacionais de inovação, ou seja, ao modelo sistêmico de inovação.

Apesar do avanço na concepção da PITCE, de acordo com Cano e Silva (2010), do ponto de vista do desempenho da indústria no seu conjunto e de sua contribuição para o crescimento e para o fortalecimento da inserção da economia brasileira no cenário internacional, os resultados produzidos não foram os esperados. O bom desempenho pôde ser verificado em algumas empresas e setores individualmente.

Além dos aspectos desfavoráveis gerados pela política macroeconômica, vários outros obstáculos para a implementação de suas medidas foram observados. No que se refere às questões que envolvem a interação das instituições de ensino e pesquisa, e as empresas, verifica-se um conjunto de conflitos. Em especial, a principal divergência refere-se aos objetivos. Enquanto que as instituições de ensino e pesquisa buscam, essencialmente, a produção de artigos científicos e a formação de recursos humanos, as empresas focam na produção e comercialização de seus bens e serviços, objetivando o lucro.

Outra questão diz respeito aos limites legais dos novos incentivos fiscais. Embora apontados pela PITCE, a interpretação e a jurisprudência, em relação a quais são os tipos de despesas com atividades de PD\&I que permite a obtenção dos incentivos, não são bem definidos.

Em relação às instituições, conforme destacado por Viotti (2008), agências como a ABDI, se mostraram frágeis e insuficientes para atender às novas demandas. É ainda insuficiente o esforço de restruturação e capacitação, exigido pela nova política, por parte de instituições como o próprio Ministério da Ciência e Tecnologia (MCT), a Financiadora de Estudos e 
Projetos (Finep) e o Conselho Nacional de Desenvolvimento Científico e Tecnológico (CNPq), que são órgãos fundamentais para o sucesso da política.

A Lei de inovação, embora promova a interação entre as instituições de ensino e empresas, encontra dificuldades para atuar. O ensino de graduação e pós-graduação (e seus currículos) não converge para as necessidades do processo de aprendizado e inovação tecnológicos com a devida intensidade.

Quanto às empresas, é importante ressaltar o pouco conhecimento apresentado em relação às questões da inovação. De acordo com Viotti (2008), a maioria das empresas adota uma estratégia tecnológica passiva ou apresenta baixa capacitação para o aprendizado tecnológico. Tal condição tem gerado pouca aderência aos estímulos lançados pela política de inovação. Vale destacar, no entanto, que essa limitação decorre da história da formação e desenvolvimento das empresas brasileiras, da composição de sua estrutura, e das condições macroeconômicas em que têm sido inseridas.

Dando continuidade à PITCE, em 2008 foi lançada a Política de Desenvolvimento Produtivo - PDP (2008-2010). Em relação à PITCE, a PDP procurou dar uma maior abrangência e intensidade, ampliando o número de setores (24 setores) e os instrumentos de incentivo. Elaborada sob a coordenação do Ministério do Desenvolvimento, Indústria e Comércio Exterior (MDIC), em parceria com os ministérios da Fazenda e da Ciência e Tecnologia além de instituições como o Banco Nacional de Desenvolvimento Econômico e Social (BNDES), a PDP apresentou quatro macrometas que visavam acelerar o investimento fixo, estimular a inovação, ampliar a inserção internacional do Brasil e aumentar o número de micro e pequenas empresas exportadoras.

Para tal, diversos tipos de medidas foram adotados para estimular o crescimento e competitividade da indústria brasileira. As medidas buscavam elevar o patamar de competitividade setorial, e compreendiam questões tributárias e fiscais; financiamento; poder de compra por parte do governo; aprimoramento jurídico; regulação e apoio técnico, cujos instrumentos abrangem promoção comercial, propriedade intelectual; capacitação de recursos humanos, capacitação empresarial; e certificação e metrologia.

Dentre os grupos de programas estabelecidos pela PDP, o setor de bens de capital insere-se nos programas para fortalecer a competitividade. Dentre as principais medidas, destacam-se: 
- Desoneração tributária: compensação dos créditos tributários federais, alteração dos prazos de recolhimento de IPI, desoneração de PIS/Cofins e de IPI na aquisição de bens de capital;

- Financiamento à produção e à modernização;

- Ampliação do Recap - Regime Especial de Aquisição de Bens de Capital para Empresas Exportadoras;

- Recursos da Financiadora de Estudos e Projetos (Finep);

- Depreciação acelerada para bens de capital utilizados nas atividades de pesquisa;

- Ampliação de linhas de financiamento para aumentar o nível de investimento em inovação das empresas; e

- O regime de ex-tarifário: redução do imposto de importação de bens de capital quando não houver similar produzido no Brasil.

Dentre as medidas apresentadas para financiamento e modernização da produção no setor de bens de capital, vale destacar a criação do Programa BNDES de Sustentação do Investimento (PSI); Criação do Programa BNDES de Aquisição de Peças, Partes e Componentes de Fabricação Nacional, por Fabricantes de Bens de Capital (Finame Componentes); Criação do Programa BNDES de Modernização de Máquinas e Equipamentos (Finame Moderniza BK); Criação da Linha de Financiamento à Importação de Equipamentos do BNDES.

O PSI é um programa que busca estimular a produção, a aquisição e a exportação de bens de capital e a inovação tecnológica, por meio de outros subprogramas, a saber:

(i) BNDES PSI-Bens de Capital: tem por objetivo financiar a produção e a aquisição isolada de máquinas e de equipamentos novos, de fabricação nacional, credenciados no BNDES, e o capital de giro a eles associado.

(ii) BNDES PSI-Inovação: visa apoiar empresas no desenvolvimento de capacidade para empreender atividades inovativas em caráter sistemático, bem como apoiar projetos de inovação de natureza tecnológica.

(iii) BNDES PSI Exportação-Pré-Embarque: financia, na fase pré-embarque, a produção de bens de capital destinados à exportação.

Quanto à linha de financiamento do Finame Componentes/BNDES, ela foi criada para apoiar a indústria de base do Brasil, dando ênfase à nacionalização dos bens de capital. Compreende 
aquisição de peças, de partes e de componentes de fabricação nacional para incorporação em máquinas e em equipamentos em fase de produção. A participação média do BNDES nessas operações foi de $90 \%$.

O Programa BNDES/Finame Moderniza BK é uma linha de financiamento do BNDES voltada para a modernização de máquinas e equipamentos instalados no País. Entende-se como modernização:

(i) Reconstrução e/ou recuperação da máquina ou do equipamento, mediante a incorporação de novas tecnologias e/ou de peças e de componentes que ampliem a vida útil e/ou otimizem sua performance original, gerando um aumento da capacidade de produção e da produtividade para a economia nacional; e

(ii) Conversão da máquina ou equipamento sem dispositivo de segurança para adequação aos requisitos de segurança do trabalho estabelecidos pela Associação Brasileira de Normas Técnicas (ABNT).

A participação média do BNDES nessas operações foi de $70 \%$.

Por fim, a linha de financiamento à importação de equipamentos do BNDES é voltada para importação de máquinas e de equipamentos novos sem similar nacional, em projetos de investimento apoiados pelo BNDES, exceto nos casos de:

(i) Equipamentos móveis destinados ao transporte de qualquer natureza, inclusive os de movimentação de carga, de construção, de pavimentação e de agropecuária, incluindo chassis e carrocerias;

(ii) Equipamentos de automação bancária; e

(iii) Máquinas e equipamentos já internados no País.

Outro programa importante no qual se insere o setor de bens de capital é o Programa BNDES Proengenharia, que prevê financiamento de gastos de engenharia no Brasil. Podem ser financiados os custos e despesas diretas, associados às atividades de engenharia de desenvolvimento e aperfeiçoamento de produtos e processos, desenvolvidos em território nacional. Dentre os custos e despesas diretas incluem-se máquinas e equipamentos nacionais, mão-de-obra e materiais, testes e ensaios; despesas, no país e no exterior, relativas à propriedade industrial do projeto; obras civis, montagens e instalações; e importação de equipamentos novos sem similar nacional. 
Vale notar que as medidas de apoio à importação de máquinas e de equipamentos favoreçam, de certo modo, a modernização, a transferência de tecnologia e conhecimento, o aumento da eficiência e da produtividade do parque industrial brasileiro.

Os desafios dos programas da PDP para o setor de bens de capital podem ser vistos como em termos de (i) expansão da capacidade de produção; (ii) fortalecimento da engenharia; (iii) ampliação da inserção internacional; (iv) adensamento da cadeia e fortalecimento das empresas de capital nacional (ECNs); e (v) apoio à modernização e consolidação empresarial. Os respectivos instrumentos são apresentados na Quadro 7.

A Política de Desenvolvimento Produtivo (PDP) avançou em relação à PITCE ao ampliar o conjunto de instrumentos e de setores contemplados. Apesar de as medidas serem fundamentalmente horizontais, verifica-se um esforço para as políticas setoriais. Embora a PDP apresente medidas voltadas para o setor de bens de capital, a heterogeneidade do setor dificulta a aderência às políticas como um todo, por parte das empresas.

Quadro 6: Inciativas e instrumentos da PDP para o setor de bens de capital

\begin{tabular}{|c|c|c|c|c|c|c|}
\hline Desafios & \multicolumn{6}{|c|}{ Instrumentos } \\
\hline $\begin{array}{l}\text { Expansão da } \\
\text { capacidade de produção }\end{array}$ & $\begin{array}{l}\text { Depreciação } \\
\text { acelerada }\end{array}$ & \multicolumn{2}{|c|}{$\begin{array}{l}\text { BNDES: Finem; } \\
\text { Finame }\end{array}$} & \multicolumn{2}{|c|}{$\begin{array}{l}\text { Lei do Bem: } \\
\text { RECAP }\end{array}$} & $\begin{array}{c}\text { INPI: } \\
\text { licenciamento e } \\
\text { transferência de }\end{array}$ \\
\hline $\begin{array}{l}\text { Fortalecimento da } \\
\text { engenharia }\end{array}$ & $\begin{array}{l}\text { Desoneração do } \\
\text { investimento }\end{array}$ & $\begin{array}{l}\text { BNDES: } \\
\text { linhas } \\
\text { inovação, } \\
\text { capital de } \\
\text { risco. }\end{array}$ & \multicolumn{2}{|c|}{$\begin{array}{l}\text { Finep, crédito, } \\
\text { subvenção, } \\
\text { capital de risco }\end{array}$} & $\begin{array}{c}\text { INPI: } \\
\text { gestão da } \\
\text { propriedade } \\
\text { intelectual }\end{array}$ & $\begin{array}{l}\text { MCT: Sibratec; } \\
\text { MDIC: Inmetro: } \\
\text { TIB }\end{array}$ \\
\hline $\begin{array}{l}\text { Ampliação da inserção } \\
\text { internacional }\end{array}$ & $\begin{array}{l}\text { BNDES: Exim } \\
\text { pré-embarque e } \\
\text { pós-embarque }\end{array}$ & \multicolumn{2}{|c|}{ MF: desoneração } & \multicolumn{2}{|c|}{$\begin{array}{c}\text { APEX/MDIC: } \\
\text { promoção comercial }\end{array}$} & $\begin{array}{l}\text { MRE/MDIC: } \\
\text { acordos de } \\
\text { acesso a } \\
\text { mercados } \\
\text { emergentes }\end{array}$ \\
\hline $\begin{array}{l}\text { Adensamento da cadeia } \\
\text { e fortalecimento das } \\
\text { ECNs }\end{array}$ & $\begin{array}{l}\text { BNDES: Finem; } \\
\text { Finame } \\
\text { (Modermaq, } \\
\text { Moderniza BK e } \\
\text { Componentes) }\end{array}$ & $\begin{array}{l}\text { MCT: } \\
\text { Sibratec }\end{array}$ & \multicolumn{2}{|c|}{$\begin{array}{l}\text { Senai: } \\
\text { formação e } \\
\text { treinamento }\end{array}$} & $\begin{array}{l}\text { Inmetro: } \\
\text { TIB }\end{array}$ & $\begin{array}{l}\text { MDIC: apoio } \\
\text { técnico à defesa } \\
\text { comercial }\end{array}$ \\
\hline $\begin{array}{l}\text { Apoio à modernização } \\
\text { e consolidação } \\
\text { empresarial. }\end{array}$ & $\begin{array}{c}\text { BNDES: Finem; } \\
\text { Finame, Fundos } \\
\text { de Equity }\end{array}$ & \multicolumn{4}{|c|}{ CADE: defesa da concorrência } & $\begin{array}{l}\text { Casa Civil: } \\
\text { compras PAC }\end{array}$ \\
\hline $\begin{array}{l}\text { MF: Ministério da F } \\
\text { Básica; APEX: Agê } \\
\text { Relações Exteriores; F }\end{array}$ & $\begin{array}{l}\text { da; PAC: Progr } \\
\text { Brasileira de Pr } \\
\text { Financiament }\end{array}$ & $\begin{array}{l}\text { de Acele } \\
\text { ção de E } \\
\text { Empreend }\end{array}$ & $\begin{array}{l}\text { ão do } \\
\text { rtaçõ } \\
\text { entos. }\end{array}$ & $\begin{array}{l}\text { scim } \\
\text { Inve } \\
\text { en. }\end{array}$ & $\begin{array}{l}\text { TIB: Tec } \\
\text { entos; MR } \\
\text { ciadora de }\end{array}$ & $\begin{array}{l}\text { gia Industrial } \\
\text { Ministério das } \\
\text { udos e Projetos. }\end{array}$ \\
\hline
\end{tabular}

Fonte: MDIC (2014) 
Dentre os instrumentos para a implantação da PDP, vale ressaltar o papel importante destinado ao BNDES para os financiamentos e aporte dos recursos. Conforme Albuquerque et al. (2012), o BNDES contribuiu de maneira imprescindível para a implantação de uma forte indústria de bens de capital no país, com certa consonância com uma política de substituição de importações. Suas principais políticas de apoio têm sido pautadas por mecanismos de incentivo à demanda, por meio de financiamentos à compra de máquinas e equipamentos.

Todavia, para que a indústria de máquinas e equipamentos possa competir no paradigma de competitividade global, outros mecanismos de apoio para uma modernização da oferta são necessários. É preciso destinar estímulos concomitantes para a oferta e para a demanda, ou seja, disponibilizar políticas de incentivo para o fabricante, por meio de financiamentos para aquisição de novas tecnologias, para a capacitação da mão-de-obra, que busquem o aumento de produtividade, e disponibilizar financiamentos com condições financeiras vantajosas para os compradores.

Em 2011, com o início de um novo governo, tem-se a terceira versão da política industrial do novo milênio, o Plano Brasil Maior (PBM). O PBM estabelece um conjunto de medidas, que serão complementadas ao longo do período 2011-2014. O Plano Brasil Maior surge num contexto de mudança e transformação da economia mundial. Têm-se de um lado vários países desenvolvidos inseridos numa crise financeira intensa, e de outro, a ascensão econômica de países emergentes, com destaque ao crescimento chinês. Nesse sentido, o desafio da nova política industrial é o de prover um crescimento econômico caracterizado por um contexto adverso.

O Plano estabelece um conjunto de medidas, no qual destacam-se:

- Desoneração dos investimentos e das exportações;

- Ampliação e simplificação do financiamento ao investimento e às exportações;

- Aumento de recursos para inovação;

- Aperfeiçoamento do marco regulatório da inovação;

- Fortalecimento da defesa comercial;

- Regulamentação da lei de compras governamentais para estimular a produção e a inovação no país.

De Acordo com o MDIC, a política Industrial está constituída por duas dimensões e organizada setorialmente em cinco blocos produtivos, a saber: 
Dimensão sistêmica: de natureza horizontal e transversal, destina-se a orientar ações que visam, sobretudo:

- Reduzir custos, acelerar o aumento da produtividade e promover bases mínimas de isonomia para as empresas brasileiras em relação a seus concorrentes internacionais; e

- Consolidar o sistema nacional de inovação por meio da ampliação das competências científicas e tecnológicas e sua inserção nas empresas.

Esta dimensão articula-se com a dimensão estruturante e é constituída por grandes temas, apresentados no Quadro 8.

\section{Quadro 7: Temas da dimensão sistêmica do Plano Brasil Maior}

\begin{tabular}{|c|c|}
\hline $\begin{array}{l}\text { Comércio } \\
\text { Exterior }\end{array}$ & $\begin{array}{l}\text { - Melhoria nos instrumentos financeiros e tributários de estímulo às exportações. } \\
\text { - Defesa comercial, consolidação e harmonização de regras tarifárias. } \\
\text { - Facilitação do comércio. } \\
\text { - Estímulo à internacionalização de empresas nacionais visando a ampliação de mercados e } \\
\text { o acesso a novas tecnologias. } \\
\text { - Atração de centros de pesquisa e desenvolvimento de empresas estrangeiras para o país. }\end{array}$ \\
\hline $\begin{array}{l}\text { Incentivo ao } \\
\text { Investimento }\end{array}$ & $\begin{array}{l}\text { - Prazos e juros compatíveis com os níveis internacionais no financiamento de longo prazo. } \\
\text { - Eliminação ou redução dos encargos tributários sobre o investimento. }\end{array}$ \\
\hline $\begin{array}{l}\text { Incentivo à } \\
\text { Inovação }\end{array}$ & $\begin{array}{l}\text { - Aprofundamento das políticas em curso, buscando maior inserção em áreas tecnológicas } \\
\text { avançadas. } \\
\text { - Base dos estímulos à inovação constituída pela Estratégia nacional de Ciência, tecnologia } \\
\text { e inovação (ENCTI), do Ministério da Ciência e Tecnologia (MCT). }\end{array}$ \\
\hline $\begin{array}{l}\text { Formação e } \\
\text { Qualificação } \\
\text { Profissional }\end{array}$ & $\begin{array}{l}\text { Constituição de programas federais voltados para o ensino técnico profissionalizante e de } \\
\text { estímulo às engenharias: } \\
\text { - Programa Nacional de Acesso à Escola Técnica (PRONATEC). } \\
\text { - Plano nacional Pró-Engenharia. } \\
\text { - Programa Ciência sem Fronteiras. }\end{array}$ \\
\hline
\end{tabular}

Fonte: Elaborado pelo autor a partir de MDIC (2014)

Dimensão estruturante: é voltada para a melhoria da eficiência produtiva, à modernização tecnológica e ao aumento da produtividade da indústria brasileira em escala internacional. 
No que se refere à agenda setorial para o setor de bens de capital, o Plano Brasil Maior dispõe de três objetivos fundamentais: (i) aumentar o Consumo Aparente de BK, com redução simultânea do coeficiente de importação; (ii) aumentar as exportações de BK; e (iii) aumentar a competitividade da indústria de BK. Seguem no Quadro 9, as principais iniciativas para os respectivos objetivos.

Quadro 8: Objetivos e iniciativas do Plano Brasil Maior para o setor de bens de capital

\begin{tabular}{|c|c|}
\hline \multirow{6}{*}{$\begin{array}{l}\text { Aumentar o consumo aparente de } \\
\text { bens de capital, com redução } \\
\text { simultânea do coeficiente de } \\
\text { importação }\end{array}$} & $\begin{array}{l}\text { Completar a desoneração dos investimentos em bens de capital } \\
\text { eliminando os impostos não recuperáveis ao longo da cadeia produtiva } \\
\text { e permitindo o crédito imediato de todos os impostos incidentes na } \\
\text { compra de bens de capital. }\end{array}$ \\
\hline & $\begin{array}{l}\text { Exigir contrapartida de conteúdo local mínimo, estabelecido por } \\
\text { família de produtos, nas compras de empresas, autarquias e entidades } \\
\text { públicas, nos financiamentos com recursos públicos, nas concessões } \\
\text { públicas e nos regimes com incentivo fiscal. }\end{array}$ \\
\hline & $\begin{array}{l}\text { Regulamentar a lei referente às compras públicas dando até } 25 \% \text { de } \\
\text { margem de preferência, em função do conteúdo local, na aquisição dos } \\
\text { bens de capital. }\end{array}$ \\
\hline & $\begin{array}{l}\text { Conceder financiamentos competitivos, em volume e em condições } \\
\text { comparáveis aos que os nossos concorrentes internacionais dispõem, de } \\
\text { modo a estimular níveis crescentes de conteúdo local e de engenharia } \\
\text { nacional nos bens de capital brasileiros. }\end{array}$ \\
\hline & $\begin{array}{l}\text { Apoiar a renovação do parque de bens de capital da indústria brasileira, } \\
\text { inclusive nos aspectos de segurança e eficiência energética, através de } \\
\text { incentivos fiscais e creditícios. }\end{array}$ \\
\hline & $\begin{array}{l}\text { Aprimorar os mecanismos de defesa comercial, evitar ou restringir a } \\
\text { concessão de "ex" e rever os regimes especiais aduaneiros, visando } \\
\text { garantir isonomia aos produtos nacionais face aos importados. }\end{array}$ \\
\hline \multirow{4}{*}{$\begin{array}{l}\text { Aumentar as exportações de bens } \\
\text { de capital }\end{array}$} & $\begin{array}{l}\text { Aumentar a exposição do setor de bens de capital brasileiro nos países } \\
\text { prioritários do programa Brazil Machinery Solutions. }\end{array}$ \\
\hline & $\begin{array}{l}\text { Ampliar e flexibilizar linhas de financiamento competitivas } \\
\text { internacionalmente para a exportação de bens de capital. }\end{array}$ \\
\hline & $\begin{array}{l}\text { Ampliar e flexibilizar a oferta de garantias aos financiamentos das } \\
\text { exportações para países em desenvolvimento e principalmente para os } \\
\text { países de menor desenvolvimento relativo. }\end{array}$ \\
\hline & $\begin{array}{l}\text { Exigir conteúdo nacional mínimo na compra de bens de capital para } \\
\text { obra, bens e serviços realizados no exterior com financiamento público } \\
\text { brasileiro. }\end{array}$ \\
\hline \multirow{6}{*}{$\begin{array}{l}\text { Aumentar a competitividade da } \\
\text { indústria de bens de capital }\end{array}$} & $\begin{array}{l}\text { Elaborar plano de desenvolvimento de fornecedores para bens de } \\
\text { capital estratégicos. }\end{array}$ \\
\hline & Fortalecer as Empresas de Engenharia Nacional. \\
\hline & Identificar Fronteiras Tecnológicas na Cadeia de Bens de Capital. \\
\hline & Incentivar Investimentos em P,D\&I. \\
\hline & Investir na formação de quadros técnicos qualificados. \\
\hline & Aprimoramento de tecnologias maduras. \\
\hline
\end{tabular}

Fonte: Elaborado a partir de Agenda Setorial/Bens de Capital - PBM - Abimaq 
Conforme Abimaq (2011), para o setor de bens de capital foram propostas 35 medidas. Deste total, nove medidas têm efeitos positivos sobre a manufatura e sete melhoram a competitividade do setor de bens de capital mecânico, conforme Tabela 6. Dentre as medidas que não tiveram efeito dobre a competitividade, destaca-se a desoneração da folha de pagamento.

Tabela 6: Medidas com efeitos sobre o setor de bens de capital no Plano Brasil Maior

\begin{tabular}{lc}
\hline Medidas & $\begin{array}{c}\text { Contribuem para ao } \\
\text { aumento de } \\
\text { competitividade }\end{array}$ \\
\hline BNDES Progeren & Sim \\
Crédito pré-aprovado para planos de inovação & Sim \\
Modernização do marco legal do Inmetro & Sim \\
Reintegra & Sim \\
Aumento da exigência de certificação compulsória & Sim \\
Desoneração da folha de pagamento & Não \\
Regime automotivo & Não \\
Compras governamentais & Sim \\
Harmonização das políticas de financiamento & Sim \\
\hline
\end{tabular}

Fonte: Abimaq (2011)

\subsection{Política Nacional de Ciência, Tecnologia e Inovação - PNCT\&I}

A política de ciência e tecnologia, centrada na inovação, tem inicio no final da década de 1990, com a política de Fundos Setoriais. Partindo-se do pressuposto de que para o progresso técnico e a competição internacional os investimentos em ciência, tecnologia e inovação são cruciais para o desenvolvimento do país, em 2003, é elaborada a Política Nacional de Ciência, Tecnologia e Inovação - PNCT\&I, sob coordenação do Ministério da Ciência e Tecnologia (MCT). A PNCT\&I surge como uma nova abordagem, caracterizada pela alocação de recursos públicos em atividades empresariais voltadas para a inovação, em especial, pelas agências de fomento CNPq e Finep.

De acordo com MCT (2007), as prioridades estratégicas da PNCT\&I compreendem quatro eixos, a saber:

- Expansão e Consolidação do Sistema Nacional de C,T\&I: expandir, integrar, modernizar e consolidar o Sistema Nacional de Ciência, Tecnologia e Inovação (SNCTI);

- Promoção da Inovação Tecnológica nas Empresas: intensificar as ações de fomento à inovação e de apoio tecnológico nas empresas. Acelerar o desenvolvimento de um ambiente favorável à inovação nas empresas; 
- Pesquisa, Desenvolvimento e Inovação em Áreas Estratégicas: fortalecer as atividades de pesquisa e inovação em áreas estratégicas para a soberania do País; e

- Ciência, Tecnologia e Inovação para o Desenvolvimento Social: promover a popularização e o aperfeiçoamento do ensino de ciências nas escolas, bem como a produção e a difusão de tecnologias e inovações para a inclusão e o desenvolvimento social.

Um maior detalhamento dos eixos Expansão e Consolidação do Sistema Nacional de C,T\&I e Promoção da Inovação Tecnológica nas Empresas, são apresentados no Quadro 10.

Quadro 9: Prioridades estratégicas, linhas de ação e programas da PNCT\&I - Eixo I e II

\begin{tabular}{|c|c|}
\hline Prioridades estratégicas & Linhas de ação e programas \\
\hline \multirow{3}{*}{$\begin{array}{l}\text { Expansão e Consolidação } \\
\text { do Sistema Nacional de } \\
\text { C,T\&I: }\end{array}$} & $\begin{array}{l}\text { 1. Consolidação institucional do Sistema Nacional de C,T\&I } \\
\text { • Consolidação institucional do Sistema Nacional de Ciência, Tecnologia e } \\
\text { Inovação (SNCTI) }\end{array}$ \\
\hline & $\begin{array}{l}\text { 2. Formação de recursos humanos para C,T\&I } \\
\text { - Formação, qualificação e fixação de recursos humanos para C,T\&I. }\end{array}$ \\
\hline & $\begin{array}{l}\text { 3. Infraestrutura e fomento da pesquisa científica e tecnológica } \\
\text { - Apoio à infraestrutura das Instituições Científicas e Tecnológicas (ICTs) e } \\
\text { de Institutos de Pesquisa Tecnológica (IPTs). } \\
\text { - Fomento ao desenvolvimento científico, tecnológico e de inovação. } \\
\text { - Programa Nova RNP - internet avançada para educação e pesquisa. } \\
\text { - Unidades de pesquisa científica de tecnológica do MCT. }\end{array}$ \\
\hline \multirow{3}{*}{$\begin{array}{l}\text { Promoção da Inovação } \\
\text { Tecnológica nas Empresas }\end{array}$} & $\begin{array}{l}\text { 1. Apoio à Inovação Tecnológica nas Empresas } \\
\text { - Apoio financeiro às atividades de P,D\&I e à inserção de pesquisadores nas } \\
\text { empresas. } \\
\text { - Apoio à cooperação entre empresas e ICTs. } \\
\text { - Iniciativa nacional para inovação. } \\
\text { - Capacitação de recursos humanos para inovação. } \\
\text { - Implementação de centos de P,D\&I empresariais. }\end{array}$ \\
\hline & $\begin{array}{l}\text { 2. Tecnologia para a inovação nas empresas } \\
\text { - Sistema Brasileiro de Tecnologia - SIBRATEC }\end{array}$ \\
\hline & $\begin{array}{l}\text { 3. Incentivo à Criação e à Consolidação de Empresas Intensivas em Tecnologia } \\
\text { - Programa Nacional de Apoio às Incubadoras e aos Parques Tecnológicos. } \\
\text { - INOVAR - Fomento à criação de à ampliação da indústria de capital } \\
\text { empreendedor no Brasil. } \\
\text { - Uso do poder de compra para estimular o desenvolvimento tecnológico nas } \\
\text { empresas nacionais de tecnologia. }\end{array}$ \\
\hline
\end{tabular}

Fonte: Elaborado a partir de MCT (2007)

\subsection{Políticas de incentivo à inovação tecnológica no Brasil}

Em função dos objetivos da nova política industrial e tecnológica implantada no Brasil, voltados para a promoção à inovação, os investimentos com atividades de ciência, tecnologia 
e inovação passaram de $\mathrm{R} \$ 9,5$ bilhões em 2002, para $\mathrm{R} \$ 15$ bilhões para 2006. Ao considerar-se a parcela de participação sobre o PIB, os investimentos nacionais em C,T\&I, em 2005, atingiram 1,28\%. Embora os investimentos tenham sido significativos, em relação a períodos anteriores, ainda se encontram distantes da meta de $2 \%$ do PIB, desejada há décadas. Em especial, a evolução do fomento à pesquisa no CNPq passou de menos de $\mathrm{R}$ \$ 50 milhões, em 1996, para mais de R \$ 350 milhões em 2006 Quanto aos recursos da Finep (reembolsáveis e não reembolsáveis), passaram de $\mathrm{R}$ \$ 278 milhões, em 1999, para aproximadamente $\mathrm{R} \$ 1,5$ bilhões, em 2006, de acordo com o Relatório de Gestão do Ministério de Ciência e Tecnologia (MCT, 2007a).

Os principais programas para promoção da inovação delineados pelo CNPq e pela Finep, são apresentados a seguir.

\subsubsection{Conselho Nacional de Desenvolvimento Científico e Tecnológico - CNPq}

As atividades do CNPq para o fomento à inovação são, fundamentalmente, direcionadas para a pesquisa científica e tecnológica, e para a formação de recursos humanos para pesquisa no Brasil. Responde por parcela significativa dos recursos do Ministério da Ciência e Tecnologia, e sua forma de atuação se dá principalmente através da concessão de bolsas de pesquisa, diretamente aos pesquisadores ou às instituições científicas e tecnológicas.

Dentre os programas de fomento para o desenvolvimento de inovações tecnológicas destacam-se:

- Programa RHAE-Inovação;

- Programa DCR - Desenvolvimento Científico e Tecnológico Regional;

- Bolsas de Pós-Graduação para Pesquisadores de Empresas; e

- Programa TIB - Tecnologia Industrial Básica.

O Programa RHAE é um programa de formação de recurso humanos para áreas estratégicas, cujo objetivo é o de estimular a inserção de pesquisadores (mestres e doutores) em atividades de P\&D nas empresas. Através de editais a empresa apresenta um projeto de pesquisa tecnológica e de inovação, que esteja alinhado às áreas da política industrial e tecnológica brasileira.

O Programa DCR está inserido no programa geral de fortalecimento da capacitação científica e tecnológica. Consiste na concessão de bolsas e têm por objetivo promover a fixação de 
recursos humanos, com experiência em ciência, tecnologia e inovação em empresas públicas de $\mathrm{P} \& \mathrm{D}$, empresas privadas que atuem em investigação científica ou tecnológica.

O programa de bolsas de pós-graduação para pesquisadores de empresas é constituído por dois tipos, a saber: PDI e SWI.

A Bolsa PDI refere-se a uma bolsa de pós-doutorado, voltada para o ambiente empresarial e industrial, que visa possibilitar ao pesquisador a consolidação e atualização de seus conhecimentos, assim como agregar competência às ações de pesquisa, desenvolvimento e inovação das empresas no país.

A Bolsa SWI, por sua vez, corresponde a uma bolsa de doutorado sanduíche empresarial, que tem como finalidade incentivar o pesquisador em curso de doutorado, a realizar a parte experimental de sua tese em um ambiente empresarial, participando de ações de pesquisa, desenvolvimento e inovação em empresas no país.

Além das Bolsas Empresariais, outras bolsas de apoio às atividades de extensão, desenvolvimento tecnológico e inovação, tais como as Bolsas Tecnológicas e as Bolsas de Extensão, se destacam. As Bolsas Tecnológicas são utilizadas por estudantes universitários, técnicos de laboratório, pesquisadores, especialistas e consultores, participantes de projetos tecnológicos apoiados pelo CNPq. As principais modalidades são a (i) Iniciação Tecnológica e Industrial (ITI), destinada a alunos de graduação e ensino médio, cujo objetivo é estimular o interesse para a pesquisa tecnológica; e (ii) Desenvolvimento Tecnológico e Industrial (DTI), voltada a profissionais com experiência em pesquisa, desenvolvimento e inovação. O aumento de concessão de a concessão de bolsas nessas modalidades, entre 2002 e 2006 foi de $75 \%$ e 86\%, respectivamente. O CNPq oferece ainda as modalidades Especialista Visitante, de longa duração e de curta duração, e Estágio/Treinamento no País e no exterior.

Por fim, o Programa TIB - Tecnologia Industrial Básica e Serviços Tecnológicos para a Inovação e Competitividade tem por objetivo adequar e expandir a infraestrutura de serviços tecnológicos em metrologia, normalização, tecnologias de gestão e serviços de suporte à propriedade intelectual, e à informação tecnológica com o objetivo de responder aos desafios dos obstáculos técnicos ao comércio internacional, decorrentes da crescente sofisticação do mercado e das exigências de certificação da qualidade, bem como contribuir para a competitividade das empresas e a inovação. Está estruturado em dois subprogramas: i) Infraestrutura de Tecnologia Industrial Básica; e ii) Serviços Tecnológicos para Pesquisa, Desenvolvimento e Engenharia. 
As ações de fomento têm buscado, conforme Laplane et al. (2007), consolidar uma rede de serviços tecnológicos, conduzidas pelos institutos e centros de pesquisa e desenvolvimento tecnológico e entidades tecnológicas setoriais, que ofereça suporte a estrutura produtiva brasileira, no sentido de atender aos requisitos de qualidade em produtos, serviços e sistemas de gestão, de forma a aumentar a capacidade das empresas de competir tanto no mercado interno como no externo. Por outro lado, contribui para a proteção do mercado interno da entrada de produtos e serviços que não atendam aos critérios de qualidade requeridos.

\subsubsection{Financiadora de Estudos e Projetos - FINEP}

A Financiadora de Estudos e Projetos - FINEP é uma empresa pública de direito privado, vinculada ao Ministério da Ciência e Tecnologia (MCT) e integra o Sistema Nacional de Ciência, Tecnologia e Inovação (SNCTI) como uma de suas principais agências. Tem por objetivo promover e financiar a inovação e a pesquisa científica e tecnológica em empresas e Instituições Científicas e Tecnológicas (ICTs), mobilizando recursos financeiros reembolsáveis e não reembolsáveis e integrando instrumentos, visando o desenvolvimento econômico e social do País.

Vale destacar, que a FINEP, de modo especial, destina financiamento a todos os segmentos que o compõem, ou seja, universidades, institutos de pesquisas, instituições governamentais, organizações não governamentais e empresas. Possui a capacidade de mobilizar diferentes tipos de recursos financeiros: recursos próprios, de terceiros e recursos de amplo uso no financiamento de atividades ligadas à inovação, incluindo desde a pesquisa básica até a popularização da ciência. Para tal, a FINEP atua no fomento para o desenvolvimento de inovações tecnológicas, por meio de três modalidades, a saber: (i) apoio financeiro não reembolsável; (ii) financiamentos; e (iii) investimentos (FINEP, 2007)

\section{Apoio financeiro não reembolsável}

Essa modalidade de apoio, inicialmente, foi destinada apenas às instituições sem fins lucrativos, para a realização de projetos de pesquisa científica, tecnológica ou de inovação, e realização de estudos, eventos e seminários voltados ao intercâmbio e difusão de conhecimentos. As instituições elegíveis para esse tipo de financiamento são as ICTs, que incluem universidades e outras instituições de ensino e pesquisa públicas ou privadas. A partir de 2006, o apoio financeiro não reembolsável passou a ser aplicado também a empresas, por meio de concessão de subvenção econômica. 


\section{Financiamento reembolsável}

Compreendem operações de crédito para financiamento de projetos de empresas. Essa modalidade de financiamento também pode incluir o mecanismo de equalização de juros, aplicado com recursos do Fundo Nacional de Desenvolvimento Científico e Tecnológico (FNDCT), para reduzir os encargos totais a serem desembolsados pelas empresas. As empresas e outras organizações interessadas em obter crédito podem apresentar suas propostas à FINEP a qualquer tempo.

\section{Investimentos}

Destinado a empresas inovadoras com alto potencial de crescimento através de investimento em fundos de capital de risco (capital empreendedor), do tipo fundos de venture capital e fundos de capital semente. A FINEP fomenta a construção de fundos nos quais participa de forma minoritária, junto com outros investidores.

Conforme Gráfico 8, é possível verificar a evolução significativa dos recursos desembolsados pela Finep para o financiamento de atividades ligadas à inovação. De acordo com o Relatório da Gestão da Finep 2003-2006, em Finep (2007), o aumento significativo destes números indica a mudança de patamar de atuação da FINEP. Em 2006, foi alcançado o maior orçamento dos últimos 20 anos e a movimentação de recursos superou a marca de $\mathrm{R} \$ 1,5$ bilhão. Neste ano foi registrado o recebimento de número recorde de 5300 solicitações de apoio financeiro não reembolsável.

Gráfico 8: Total de recursos reembolsáveis e não reembolsáveis- Finep

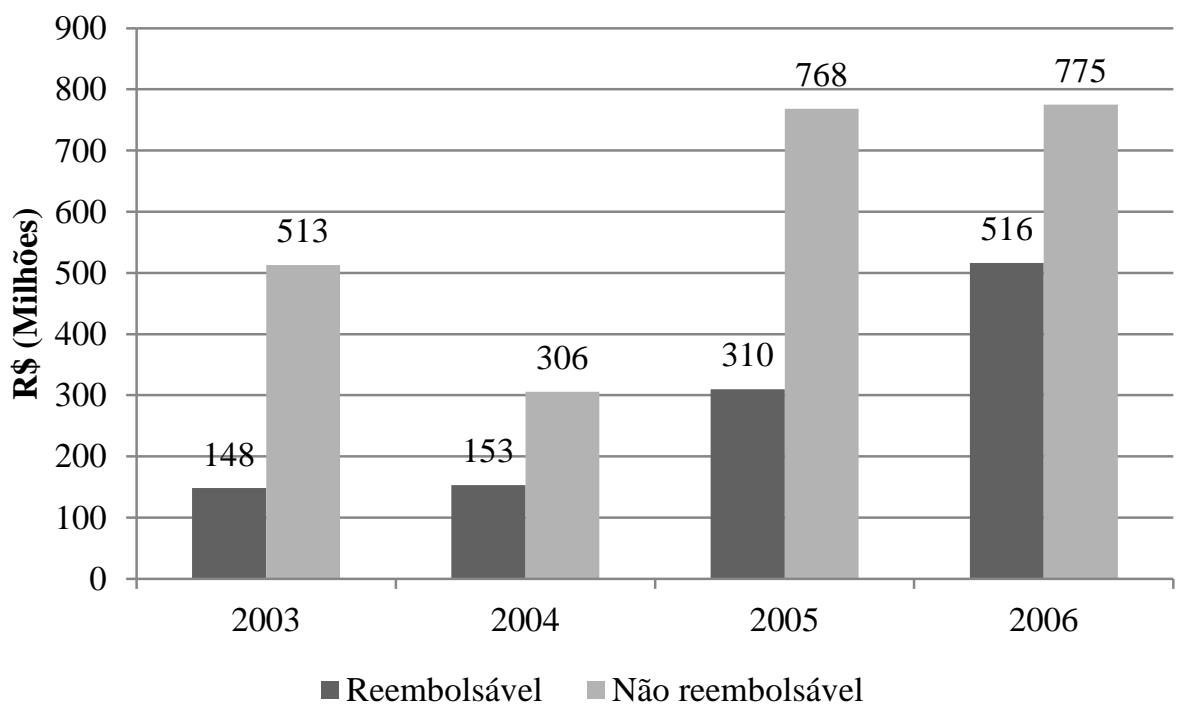

Fonte: Finep (2007) 
A Finep, ao longo dos anos, revisou e ampliou seus programas de atuação de modo a adequálos às demandas da políticas implantada. Os principais programas das três modalidades de apoio, acima destacadas, de acesso às empresas do setor de bens de capital, são apresentados na Quadro 10.

Quadro 10: Modalidades e principais programas da Finep

\begin{tabular}{|c|c|c|}
\hline Modalidades & Programas & Foco dos Programas \\
\hline \multirow{3}{*}{$\begin{array}{l}\text { Recursos } \\
\text { reembolsáveis }\end{array}$} & PROINOVAÇÃO & $\begin{array}{l}\text { Projetos de P,D\&I e capacitação tecnológica, com } \\
\text { prioridade para os setores da Política Industrial. }\end{array}$ \\
\hline & JURO ZERO & $\begin{array}{l}\text { Inovação da produção à comercialização em Micro e } \\
\text { Pequenas Empresas (MPEs), com parcerias regionais. }\end{array}$ \\
\hline & FINEPSUL & $\begin{array}{l}\text { Apoio a projetos de infraestrutura de empresas brasileiras } \\
\text { de consultoria de engenharia em Países da América do Sul. }\end{array}$ \\
\hline \multirow{4}{*}{$\begin{array}{l}\text { Recursos não } \\
\text { reembolsáveis }\end{array}$} & PAPPE & $\begin{array}{l}\text { Projetos de P\&D de produtos e processo inovadores em } \\
\text { fases que precedem a sua comercialização. Tem foco em } \\
\text { pesquisadores e suas atividades desenvolvidas em } \\
\text { empresas ou criação de MPEs tecnologicamente } \\
\text { intensivas. }\end{array}$ \\
\hline & \multirow{3}{*}{$\begin{array}{l}\text { SUBVENÇÃO } \\
\text { ECONÔMICA }\end{array}$} & $\begin{array}{l}\text { PAPPE: Atividades inovadoras de empresas alinhadas à } \\
\text { Política Industrial e setores estratégicos em parcerias com } \\
\text { agentes regionais e estaduais, focando em MPEs. }\end{array}$ \\
\hline & & $\begin{array}{l}\text { Inovação: Atividades inovadoras de empresas alinhadas à } \\
\text { Política Industrial e setores estratégicos. }\end{array}$ \\
\hline & & $\begin{array}{l}\text { Pesquisador na empresa: parcela da remuneração de } \\
\text { mestres e doutores em atividades de inovação nas } \\
\text { empresas. }\end{array}$ \\
\hline \multirow{3}{*}{ Investimentos } & $\begin{array}{l}\text { INOVAR } \\
\text { (Incubadora de Fundos) }\end{array}$ & Capital empreendedor. \\
\hline & $\begin{array}{l}\text { INOVAR } \\
\text { (Fórum de negócios) }\end{array}$ & Capitalização de MPEs tecnologicamente intensivas. \\
\hline & INOVAR SEMENTE & Estruturação de fundos locais de capital semente. \\
\hline
\end{tabular}

Fonte: Finep (2007) 


\section{MÉTODO DE PESQUISA}

Esta seção tem por objetivo apresentar a metodologia de pesquisa utilizada, com destaque para os instrumentos de coleta de dados utilizados, a composição da amostra, e as dimensões e variáveis de pesquisa explorados.

\subsection{Caracterização da pesquisa}

Com a finalidade de melhor atender aos objetivos propostos, realizou-se um estudo descritivoexploratório, de abordagem qualitativa. O propósito da pesquisa exploratória é o de incrementar o conhecimento sobre determinado problema. De acordo com Sampieri et al. (2012), os estudos exploratórios possibilitam realizar uma pesquisa mais completa sobre um contexto particular, identificar conceitos ou variáveis promissoras e estabelecer prioridades sobre pesquisas futuras. Geralmente, determinam tendências, identificam áreas, ambientes, contextos e situações de estudo, relações potenciais entre variáveis.

A pesquisa descritiva, por sua vez, busca especificar as propriedades, as características e os perfis importantes do fenômeno que se submete à análise; elas medem, avaliam informações sobre diversos aspectos, dimensões ou componentes do fenômeno a ser pesquisado (SAMPIERI et al., 2012). Nesse sentido, a o enfoque descritivo neste trabalho é de fundamental importância, pois possibilita a integração das informações das variáveis para determinar como é e como se manifesta cada elemento determinante da capacidade tecnológica observada nas empresas. Mediante os resultados, o objetivo é descrever em que medida os elementos internos e externos à empresa influenciam no seu acúmulo da capacidade tecnológica.

A opção pela abordagem qualitativa decorre da necessidade de se determinar e analisar a diversidade de características das empresas e seu meio externo, e as especificidades do setor, permitindo o resgate, a identificação e a introdução de novos fatores, além daqueles previamente definidos. A ênfase da abordagem qualitativa, de acordo com Martins (2010), está no desvendar o desenrolar de eventos que culminam nos resultados. O interesse não é apenas nos resultados, mas em como se chegou até eles. Compreende uma descrição do cenário, a análise de dados para identificar as dimensões e a interpretação ou conclusões sobre seu significado teórico (CRESWELL, 2007). Tais características vão ao encontro do propósito deste trabalho, que não recai somente em apresentar os determinantes (internos e externos) 
que influenciam no acúmulo de capacidade tecnológica das empresas, mas, principalmente, em possibilitar uma explicação de seu processo.

Conforme Neuman (1994), citado em Sampieri et al. (2012), a pesquisa qualitativa possibilita a análise em uma perspectiva dupla, focando não apenas os aspectos explícitos, conscientes, manifestos, mas também aqueles implícitos, subjacentes. Utiliza a coleta de dados e sua análise para responder às questões de pesquisa. Grinnell (1997) e Creswell (1998) apresentam quatro considerações em relação à pesquisa qualitativa, a saber:

- Existência de duas realidades: a primeira realidade referem-se às crenças, pressupostos e experiências subjetivas dos indivíduos. Podem variar de muito vagas a crenças bem organizadas e desenvolvidas. A segunda realidade é objetiva e independente das crenças que tenhamos em relação a ela;

- A realidade objetiva pode ser conhecida e analisada;

- Maior informação sobre a realidade objetiva: é necessário conhecer e obter a maior quantidade de informações sobre a realidade objetiva, pois ela existe e é certo que conhecemos os eventos à nossa volta por meio de suas manifestações. O entendimento dessa realidade requer registro e análise de tais eventos;

- Modificação ou adaptação da realidade objetiva: quando as investigações determinam que a realidade objetiva é diferente das crenças individuais, essas devem ser modificadas ou adaptadas em torno da realidade.

\subsection{Composição da amostra}

A seleção da amostra teve como ponto de partida o setor de Bens de Capital Mecânico Máquinas e Equipamentos, subdividido em quatro subsetores, segundo a Classificação Nacional de Atividades Econômicas - CNAE 2.0:

- CNAE 28.1 - Motores, bombas, compressores e equipamentos de transmissão

- CNAE 28.2 - Máquinas e equipamentos de uso geral

- CNAE 28.4 - Máquinas-ferramenta

- CNAE 28.6 - Outras máquinas e equipamentos de uso específico

A Tabela 7 apresenta, para cada empresa selecionada, seu porte, ano de fundação, sua origem e número de funcionários. 
Tabela 7: Empresas selecionadas para o estudo

\begin{tabular}{|c|c|c|c|c|}
\hline Empresa & Ano de fundação & Porte da empresa & $\begin{array}{l}\text { Número de } \\
\text { funcionários }\end{array}$ & Origem da empresa \\
\hline 1 & 1989 & Pequena & 50 & Nacional \\
\hline 2 & 1972 & Média & 100 & Nacional \\
\hline 3 & 1901 & Grande & 1000 & Nacional \\
\hline 4 & 1946 & Grande & 540 & Transnacional \\
\hline 5 & 1994 & Média & 113 & Nacional \\
\hline 6 & 1939 & Pequena & 90 & Transnacional \\
\hline 7 & 1914 & Média & 115 & Nacional \\
\hline 8 & 1986 & Pequena & 50 & Nacional \\
\hline 9 & 1952 & Média & 200 & Nacional \\
\hline 10 & 1968 & Grande & 550 & Transnacional \\
\hline 11 & 1999 & Pequena & 60 & Nacional \\
\hline 12 & 1994 & Pequena & 50 & Transnacional \\
\hline 13 & 1975 & Média & 129 & Nacional \\
\hline 14 & 1980 & Média & 250 & Transnacional \\
\hline 15 & 1974 & Média & 184 & Alemanha \\
\hline 16 & 1963 & Média & 190 & Nacional \\
\hline 17 & 1964 & Pequena & 50 & Nacional \\
\hline 18 & 1969 & Média & 140 & Transnacional \\
\hline 19 & 2004 & Pequena & 30 & Nacional \\
\hline 20 & 1970 & Média & 230 & Transnacional \\
\hline 21 & 1871 & Grande & 1000 & Transnacional \\
\hline 22 & 1996 & Pequena & 30 & Nacional \\
\hline 23 & 1899 & Pequena & 60 & Transnacional \\
\hline 24 & 1977 & Pequena & 67 & Nacional \\
\hline 25 & 1961 & Média & 130 & Nacional \\
\hline 26 & 1966 & Pequena & 65 & Nacional \\
\hline 27 & 1954 & Pequena & 72 & Nacional \\
\hline 28 & 1950 & Média & 250 & Nacional \\
\hline 29 & 1984 & Média & 140 & Nacional \\
\hline 30 & 1983 & Média & 350 & Nacional \\
\hline 31 & 1987 & Pequena & 50 & Nacional \\
\hline 32 & 1920 & Grande & 1850 & Nacional \\
\hline 33 & 1984 & Média & 110 & Nacional \\
\hline 34 & 1839 & Grande & 500 & Transnacional \\
\hline 35 & 1995 & Pequena & 40 & Nacional \\
\hline 36 & 1934 & Grande & 1300 & Transnacional \\
\hline 37 & 1949 & Grande & 600 & Transnacional \\
\hline 38 & 1982 & Pequena & 65 & Nacional \\
\hline 39 & 1987 & Média & 147 & Nacional \\
\hline 40 & 1986 & Pequena & 60 & Nacional \\
\hline 41 & 1974 & Pequena & 44 & Transnacional \\
\hline 42 & 1938 & Média & 400 & Transnacional \\
\hline 43 & 1918 & Grande & 1200 & Transnacional \\
\hline 44 & 1982 & Pequena & 42 & Nacional \\
\hline
\end{tabular}

Fonte: Elaborado a partir de pesquisa de campo

A escolha dos subsetores referidos acima se deve à sua representatividade na Formação Bruta de Capital Fixo (FBCF), que é de aproximadamente 70\%. Além das empresas pertencerem a um dos subsetores acima mencionados, outros critérios de seleção foram utilizados: 
- Porte das empresas: o estudo optou por empresas de pequeno, médio e grande portes, segundo o critério de número de funcionários. Embora o critério por faturamento seja bastante utilizado, nem todas as empresas selecionadas para esta pesquisa puderam disponibilizar essa informação. A classificação das empresas segundo o número de funcionários para o setor industrial, conforme Sebrae (2013): micro (até 19 funcionários; pequena (de 20 a 99 funcionários); média (de 100 a 499 funcionários); e grande (acima de 499 funcionários).

- Localização: a região escolhida foi a sudeste, em especial o estado de São Paulo, por abranger a parcela mais representativa de empresas do setor.

- Origem das empresas: em função da natureza do estudo, que é o de analisar aspectos da capacidade tecnológica, internos e externos às empresas, foram selecionadas somente empresas fabricantes locais, ou seja, que possuem plantas industriais no Brasil.

\subsection{Instrumentos de coleta de dados}

Este trabalho fará uso de várias fontes de evidências. Será utilizado, como instrumento principal de coletada de dados, um roteiro de questões, aplicado a partir de entrevistas presenciais, combinando perguntas abertas e fechadas, possibilitando ao informante a possibilidade de discorrer sobre o tema proposto. Entretanto, este trabalho terá como grande desafio a aplicação do questionário pessoalmente, na maior quantidade de respondentes possível, com uso de entrevistas abertas, presenciais, para produzir uma melhor interpretação das respostas (análises e conclusões).

\subsubsection{Entrevistas}

As entrevistas são essenciais e consideradas uma das fontes de informação mais importantes em uma pesquisa qualitativa. Para este trabalho as entrevistas foram presenciais, realizadas com participantes mais indicados para responderem às questões de pesquisa. As entrevistas envolveram perguntas abertas (semiestruturada) e também do tipo estruturada. $\mathrm{O}$ tipo face a face foi escolhido, para todas as entrevistas, pois permite um maior aprofundamento e cobertura mais detalhada do assunto, conforme destacado em Flick (2009). Para Creswell (2007), nas entrevistas os participantes podem fornecer informações históricas, e possuem a vantagem de permitir ao pesquisador "controlar" a linha de questionamento. Dentre os participantes que contribuíram para as questões de pesquisa foram selecionados gerentes e diretores das áreas técnica, comercial e industrial, das empresas. O objetivo principal foi o de 
buscar informantes-chave em cada empresa. No total, foram entrevistadas 52 pessoas em 47 empresas, gerando um total de aproximadamente 220 horas de entrevista.

A complexidade do tema estudado e a possibilidade de equívocos na interpretação das questões orientou a elaboração de um roteiro de entrevista semiestruturada. Conforme Gressler (2003), o roteiro de entrevistas tem por objetivo auxiliar o pesquisador na organização e estrutura antes e no momento da entrevista; ajudar o entrevistado a fornecer informações com maior precisão; e apoiar na organização da interação social no momento da entrevista e da organização dos conceitos e variáveis de pesquisa previamente indicados.

\subsubsection{Observação}

A observação tem um papel essencial pesquisa qualitativa, e é por meio desta que se procura apreender aparências, eventos e/ou comportamentos (GODOI et al., 2006). São realizadas notas de campo sobre as atividades das pessoas na empresa, registradas de uma maneira não estruturada ou semiestruturada. Ela pode ser do tipo direta ou não participante, e participante. $\mathrm{Na}$ observação direta ou não participante o pesquisador atua somente como espectador, procurando ver e registrar o máximo de ocorrências que se relacionam ao trabalho. Podem ser incluídas nesse tipo as observações realizadas em reuniões e entrevistas. Na observação participante, ao contrário da observação direta, o pesquisador assume uma variedade de funções, podendo participar de eventos que estão sendo estudados, conforme destacado em Creswell (2007). Em outros termos, tem-se um observador passivo na primeira modalidade, e um participativo na segunda.

\subsubsection{Análise de documentos}

A análise de documentos também é importante, pois amplia as evidências provindas de outras fontes. Documentos podem incluir materiais escritos como relatórios, memorandos, catálogos, documentos administrativos, ou registros organizados em banco de dados. Os documentos são importantes por representar os dados refletidos, aos quais os participantes dedicaram atenção para compilar (CRESWELL, 2007).

\subsection{Análise dos dados coletados}

A análise dos dados coletados apoiou-se no método da análise de conteúdo, considerado de grande pertinência às pesquisas qualitativas. De acordo com Bardin (1977), a análise de conteúdo é definida como um conjunto de técnicas que analisam diferentes conteúdos, verbais 
e não verbais, que permitem a inferência de conhecimentos relativos às condições de produção/recepção (variáveis inferidas) destas mensagens.

Análise de conteúdo, de acordo com Flick (2009), possui a vantagem em relação aos métodos indutivos, já que a formalização do procedimento permite gerar categorias que facilitam a comparação entre os diferentes casos. De fato, a principal característica é a utilização de categorias, as quais são levadas para o material empírico e não necessariamente desenvolvidas a partir deste, embora sejam reiteradamente avaliadas em contraposição a esse material e, se necessário, modificadas.

Bardin (2006) apresenta um procedimento, em várias etapas organizadas em três fases, para a análise qualitativa de conteúdo, conforme a Figura 15.

A primeira fase, Pré-análise, tem por objetivo a sistematização das ideias iniciais a partir do referencial teórico e estabelecer indicadores para a interpretação das informações coletadas. A fase compreende (i) a Leitura "flutuante", que é o primeiro contato com os documentos da coleta de dados. É o momento em que se começa a conhecer os textos, entrevistas e demais fontes a serem analisadas; (ii) a escolha dos documentos, que consiste na definição do corpus de análise; (iii) a formulação dos objetivos, a partir da leitura inicial dos dados; e (iv) a elaboração de indicadores, com o objetivo de interpretar o material coletado.

A escolha dos dados, no entanto, devem respeitar algumas regras, a saber:

- Exaustividade: refere-se à exaustação da comunicação, ou seja, não deixar de fora da pesquisa qualquer um de seus elementos.

- Representatividade: no caso da seleção um número muito elevado de dados, pode efetuarse uma amostra, a qual faça parte representativa do universo inicial.

- Homogeneidade: os documentos devem ser homogêneos, ou seja, seguir critérios precisos de escolha e não apresentar demasiada singularidade.

- Pertinência: a fonte documental deve corresponder ao objetivo proposto pela análise.

A segunda fase, que se refere à exploração do material, consiste na construção das operações de codificação e na agregação das informações em categorias simbólicas ou temáticas. Vale ressaltar que é nessa fase que o texto das entrevistas e de todo o material coletado é configurado em unidades de registro. 
Figura 15: Fases da análise de conteúdo

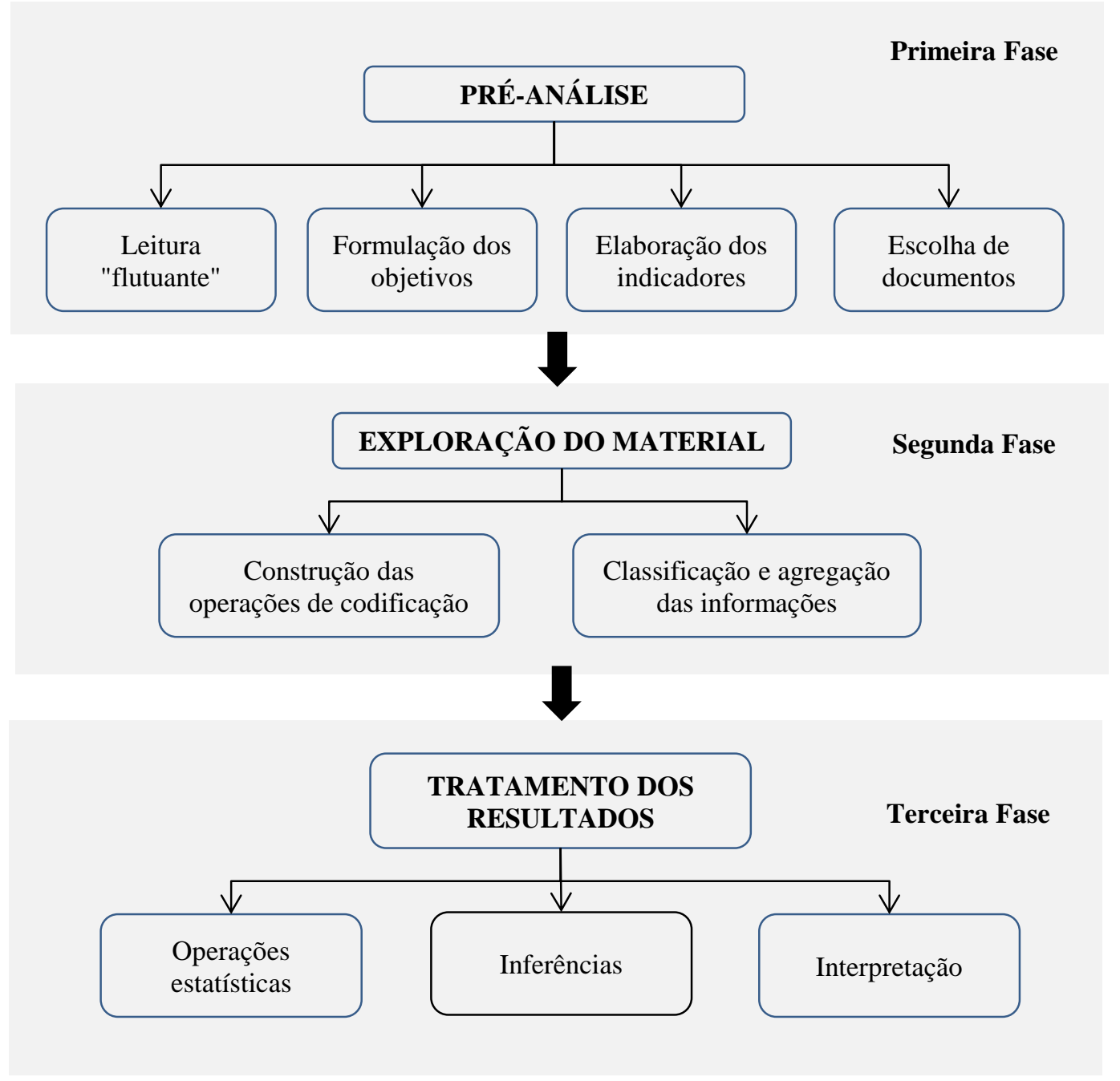

Fonte: Elaborado a partir de Bardin (1977)

A terceira, e última fase, consiste no tratamento dos resultados, inferência e interpretação. Tem como objetivo captar os conteúdos apresentados e latentes contidos em todo o material coletado (entrevistas, documentos e observação). A partir de resultados anteriores, pode-se dispor de inferências e interpretações sobre os objetivos previstos ou concebidos como diferentes.

\subsection{Execução da coleta de dados}

A execução da coleta de dados compreendeu várias etapas e atividades. A escolha das empresas que compuseram a amostra foi realizada a partir de várias fontes de cadastro e localização de empresas, dentre as quais destacam-se: Abimaq - Associação Brasileira de Máquinas e Equipamentos; prefeituras das cidades; revistas técnicas; visita à Feira da Mecânica, realizada em maio de 2014; e pesquisa pela internet. A execução da coleta de dados teve início em setembro de 2013 e finalizou em julho de 2014. 
Foram entrevistadas 52 pessoas em 47 empresas, das quais três são representantes comerciais de fabricantes localizados no exterior. Para efeito de análise dos determinantes internos e externos para o acúmulo de capacidade tecnológica, foram consideradas, conforme critério da amostra, somente os fabricantes locais, que totalizaram 44 empresas.

Dentre os participantes que contribuíram para as questões de pesquisa foram selecionados gerentes e diretores das áreas técnica, comercial e industrial, das empresas. O objetivo principal foi o de buscar informantes-chave em cada empresa.

As empresas foram contatadas todas por telefone, sendo a comunicação por e-mail realizada para apresentação de documentos, comprovando o vínculo acadêmico e formalização do conteúdo da pesquisa.

Depois de agendadas as entrevistas, foram realizadas as visitas até as sedes das empresas. A média de duração das visitas foi de 4 horas e compreendeu apresentação das dependências da planta e dos processos organizacionais pertinentes aos objetivos da pesquisa. $\mathrm{O}$ total de horas em visitas (entrevistas e apresentações) foi de aproximadamente 220 horas, e em $25 \%$ das empresas foi permitida a gravação em áudio. As principais informações dos áudios foram transcritas e categorizadas conforme os objetivos da pesquisa. 


\section{ANÁLISE DOS RESULTADOS}

\subsection{Características gerais das empresas}

\subsubsection{Perfil da amostra}

Conforme a Tabela 8, a amostra desta pesquisa compreendeu 44 empresas do segmento de bens de capital, sendo 79,5\% de pequeno e médio portes. As empresas de grande porte representam $20,5 \%$ do total. Não foram pesquisadas microempresas.

Aproximadamente $61 \%$ das empresas são independentes e 39,6\% pertencem a algum grupo. Quanto ao capital controlador, a ampla maioria é nacional (65,9\%). O estrangeiro corresponde a $20,5 \%$ e o capital misto a $13,6 \%$. Do total da amostra, aproximadamente dois terços das empresas são nacionais, sendo as demais de origem estrangeira. Dentre os países estrangeiros destacam-se a Alemanha, com aproximadamente um quarto da amostra.

Tabela 8: Perfil das empresas

\begin{tabular}{|c|c|c|c|}
\hline Perfil & Descrição & QTD & $\%$ \\
\hline \multirow{4}{*}{ Porte } & Microempresa & 0 & $0,0 \%$ \\
\hline & Pequena empresa & 18 & $40,9 \%$ \\
\hline & Média empresa & 17 & $38,6 \%$ \\
\hline & Grande empresa & 9 & $20,5 \%$ \\
\hline \multirow{2}{*}{ Vínculo da empresa } & Empresa independente & 27 & $61,4 \%$ \\
\hline & Empresa parte de um grupo & 17 & $38,6 \%$ \\
\hline \multirow{3}{*}{ Capital controlador } & Nacional & 29 & $65,9 \%$ \\
\hline & Estrangeiro & 9 & $20,5 \%$ \\
\hline & Misto & 6 & $13,6 \%$ \\
\hline \multirow{7}{*}{ País de origem } & Brasil & 28 & $63,6 \%$ \\
\hline & Alemanha & 10 & $22,7 \%$ \\
\hline & Escócia & 1 & $2,3 \%$ \\
\hline & França & 1 & $2,3 \%$ \\
\hline & Itália & 2 & $4,5 \%$ \\
\hline & Finlândia & 1 & $2,3 \%$ \\
\hline & Suíça & 1 & $2,3 \%$ \\
\hline
\end{tabular}

Fonte: Elaborado a partir de pesquisa de campo

As empresas da amostra, em sua maioria, já estão no mercado há algumas décadas. Do total de empresas selecionadas 9,1\% foram fundadas há menos de 20 anos. Metade das empresas possui entre 20 a 49 anos de idade, e 40,9\% já tem presença no mercado há mais de 50 anos. Vale destacar que aproximadamente $10 \%$ das empresas já possuem um século ou mais de existência. 


\subsubsection{Atividades principais e segmentos atendidos}

A indústria de bens de capital compreende um conjunto heterogêneo de segmentos e produtos, e é demandada também por uma heterogeneidade de segmentos. Os principais produtos e os segmentos atendidos, analisados nas empresas, são apresentados na Quadro 13.

Quadro 11:Principais produtos e segmentos atendidos pelas empresas pesquisadas

\begin{tabular}{|c|c|}
\hline Principais produtos fabricados & Principais setores/segmentos atendidos \\
\hline Centros de usinagem $\mathrm{CNC}$ & Mineração \\
\hline Máquinas para embalagem & Construção civil \\
\hline Válvulas industriais & Petróleo e gás \\
\hline Bombas & Alimentos \\
\hline Tornos convencionais & Papel e celulose \\
\hline Tornos automáticos universais $\mathrm{CNC}$ & Sucroalcooleiro \\
\hline Prensas mecânicas & Têxtil \\
\hline Máquinas para corte & Agricultura \\
\hline Prensas hidráulicas & Rodoviário \\
\hline Máquinas de tear & Metal mecânico em geral \\
\hline Máquinas de movimentação e armazenagem & Automobilístico \\
\hline Máquina misturador de borracha para pneus & Aeroespacial \\
\hline Injetoras de plásticos & Logístico \\
\hline Bobinadeiras & Elétrico \\
\hline Ponte rolante & Siderúrgico \\
\hline Comportas hidráulicas & Petroquímico \\
\hline Máquinas para tabaco & Metalúrgico \\
\hline Empilhadeiras & Eletroeletrônico \\
\hline Filtros industriais & Veículos pesados \\
\hline \multirow[t]{2}{*}{ Ferramentas de corte } & Naval \\
\hline & Saneamento \\
\hline
\end{tabular}

Fonte: Elaborado a partir de pesquisa de campo

Para as empresas pesquisadas, as atividades principais compreendem máquinas e equipamentos, com $81 \%$ da amostra, e componentes, com 19\%. Dentre os diversos produtos apresentados pelas empresas foram destacados aqueles que compõem a maior parte da receita líquida de vendas. $\mathrm{O}$ destino dos produtos fabricados também abrange diversos setores e segmentos da economia, tais como papel e celulose, mineração, petróleo e gás, alimentos, siderúrgico, entre outros, conforme mostrado no Quadro 13. 


\subsubsection{Mercado}

Em relação ao mercado foram analisados aspectos quanto a vendas para o mercado interno e externo; os principais mercados de exportação; o grau de exigência tecnológica dos mercados atendidos, e o grau de influência da China na competitividade dos produtos.

Tabela 9: Características de mercado

\begin{tabular}{|c|c|c|c|}
\hline Dimensões & Descrição & QTD & $\%$ \\
\hline \multirow{3}{*}{$\%$ Vendas no mercado interno } & De $60 \%$ a $80 \%$ & 9 & $20,5 \%$ \\
\hline & De $81 \%$ a $90 \%$ & 8 & $18,1 \%$ \\
\hline & De $91 \%$ a $100 \%$ & 27 & $61,4 \%$ \\
\hline \multirow{5}{*}{$\%$ Vendas no mercado externo } & Não exporta & 14 & $31,8 \%$ \\
\hline & Até $5 \%$ & 13 & $29,6 \%$ \\
\hline & De $10 \%$ a $20 \%$ & 10 & $22,7 \%$ \\
\hline & De $21 \%$ a $30 \%$ & 3 & $6,8 \%$ \\
\hline & De $31 \%$ a $50 \%$ & 4 & $9,1 \%$ \\
\hline \multirow{4}{*}{ Evolução do market share } & Diminuiu & 6 & $13,6 \%$ \\
\hline & Manteve & 15 & $34,1 \%$ \\
\hline & Cresceu & 17 & $38,6 \%$ \\
\hline & Oscilou & 6 & $13,6 \%$ \\
\hline \multirow{3}{*}{ Grau de exigência tecnológica no Brasil } & Baixo & 7 & $15,9 \%$ \\
\hline & Médio & 10 & $22,7 \%$ \\
\hline & Alto & 27 & $61,4 \%$ \\
\hline \multirow{4}{*}{ Grau de exigência tecnológica no Exterior } & Não exporta & 14 & $31,8 \%$ \\
\hline & Baixo & 3 & $6,8 \%$ \\
\hline & Médio & 6 & $13,6 \%$ \\
\hline & Alto & 21 & $47,8 \%$ \\
\hline \multirow{4}{*}{ Influência da China na competitividade } & Não influencia & 5 & $11,4 \%$ \\
\hline & Baixo & 20 & $45,4 \%$ \\
\hline & Médio & 4 & $9,1 \%$ \\
\hline & Alto & 15 & $34,1 \%$ \\
\hline
\end{tabular}

\section{Fonte: Elaborado a partir de pesquisa de campo}

Conforme Tabela 9, as vendas estão concentradas no mercado interno. Um total de 79,5\% das empresas comercializa mais de $80 \%$ de seus produtos no país. A exportação não ocorre em $31,8 \%$ das empresas e somente $16 \%$ exportam de $21 \%$ a $50 \%$ de sua produção. De acordo com a Tabela 9, o volume de vendas para o mercado externo, realizado pela maioria das empresas, é muito baixo, aproximadamente $84 \%$ das empresas exportam até $20 \%$ de seu volume de produção, sendo que deste total $56 \%$ não superam os $5 \%$.

Para as empresas exportadoras, os principais mercados de destino compreendem países da América Latina, Europa, Ásia, África, e América do Norte, conforme Tabela 10. 
O principal mercado das exportações, para a maioria das empresas, é o da América Latina, representando $85,2 \%$ da amostra, sendo o principal país de destino a Argentina, Chile e Colômbia, com aproximadamente 55\%, $40 \%$ e $33 \%$ das empresas exportadoras, respectivamente. Em seguida, tem-se a Europa e América do Norte, com 33,3\% de empresas para cada continente. A Ásia é destino das exportações para aproximadamente um quarto das empresas, e por fim a África com uma parcela pouco representativa, de 7,4\%.

Tabela 10: Destino das exportações

\begin{tabular}{lcl}
\hline Destino das exportações & $\begin{array}{c}\text { Exportações (\%) } \\
\text { (em volume de vendas) }\end{array}$ & \multicolumn{1}{c}{ Países } \\
\hline América Latina (exceto México) & $85,2 \%$ & $\begin{array}{l}\text { Peru, Argentina, Colômbia, Equador, Paraguai, } \\
\text { Venezuela, Paraguai, Chile, Bolívia e República } \\
\text { Dominicana e Peru. }\end{array}$ \\
\hline Europa & $33,3 \%$ & $\begin{array}{l}\text { Espanha, Itália, Alemanha, Rússia, Turquia, } \\
\text { Hungria, Reino Unido. }\end{array}$ \\
\hline América do Norte & $33,3 \%$ & Estados Unidos da América e México \\
\hline Ásia & $25,9 \%$ & Turquia, China, Índia, Iraque. \\
\hline África & $7,4 \%$ & Angola, Moçambique. \\
\hline
\end{tabular}

Fonte: Elaborado a partir de pesquisa de campo

É importante ressaltar que as empresas que exportam para a Europa e EUA são praticamente as mesmas, ou seja, é possível afirmar que as empresas que conseguem competir nos EUA também conseguem exportar para a Europa.

Outro aspecto importante a ser considerado em relação aos mercados atendidos é o grau de exigência tecnológica. Para o mercado interno, em aproximadamente $60 \%$ das empresas pesquisadas o grau de tecnologia exigido é considerado elevado. Para aproximadamente um quarto das empresas da amostra (23,8\%), o grau de exigência tecnológica é médio e para somente $16,7 \%$ é considerado baixo.

No entanto, em relação aos principais mercados externos atendidos, ou seja, na América Latina, $70 \%$ consideram o grau de tecnologia exigido como alto, $20 \%$ como médio e aproximadamente $10 \%$ como baixo. Pode-se observar que as empresas que exportam se deparam, de maneira geral, com mercados mais exigentes do ponto de vista tecnológico.

A baixa presença no mercado internacional traz implicações importantes para o acúmulo de capacidade tecnológica. De acordo com Ferraz et al. (1997), a atuação no mercado internacional expõe a empresa ao contato de uma clientela mais variada, em geral com 
elevados níveis de exigência e disputada por grandes número de concorrentes, o que favorece substancialmente os processos de aprendizado.

É importante destacar a influência dos produtos da China na competitividade das empresas pesquisadas. Em apenas $10 \%$ da amostra, a presença de produtos chineses no mercado nacional não influencia em sua competitividade, e para mais de $42 \%$ das empresas, a China exerce uma influencia média-alta. Entretanto, é importante relacionar o grau de exigência tecnológica com o grau de influência da China na competitividade. Conforme Tabela 11, nota-se que a China, em nichos de mercado em que há um alto grau de exigência tecnológica, ela exerce alta influência na competitividade para aproximadamente um quarto das empresas $(22,5 \%)$, mas também ocorre uma baixa influência para 27,5\% das empresas fabricantes no Brasil.

Tabela 11: Influência da China (\% do total)

\begin{tabular}{lccccc}
\hline Grau de Exigência Tecnológica & $\begin{array}{c}\text { Não } \\
\text { influencia }\end{array}$ & Baixa & Média & Alta & Total \\
\hline Baixo & $5,0 \%$ & $5,0 \%$ & $5,0 \%$ & $2,5 \%$ & $17,5 \%$ \\
\hline Médio & $0,0 \%$ & $15,0 \%$ & $0,0 \%$ & $10,0 \%$ & $25,0 \%$ \\
\hline Alto & $5,0 \%$ & $27,5 \%$ & $2,5 \%$ & $22,5 \%$ & $57,5 \%$ \\
\hline Total (\%) & $10,0 \%$ & $47,5 \%$ & $7,5 \%$ & $35,0 \%$ & $100,0 \%$ \\
\hline
\end{tabular}

Fonte: Elaborado a partir de pesquisa de campo

Vale dizer que a China não apenas compete em nichos de mercado onde a exigência tecnológica é baixa. Conforme declarado pelos respondentes e mostrado na Tabela 11, há um crescimento da participação de empresas chinesas também em mercados nos quais prevalece um grau mais elevado de exigência tecnológica.

De maneira geral, em mercados mais segmentados ou de produtos mais complexos, a influência dos produtos chineses é menor. Há por parte dos compradores no Brasil uma incerteza no atendimento pós-venda. Vale lembrar que, no caso de máquinas operatrizes, o serviço pós-venda é crucial, já que ocorre a necessidade de acompanhamento do produto por um determinado tempo, seja para a realização de melhorias ou para treinamento de pessoal. As peças de reposição precisam também estar disponíveis e há receio do não cumprimento ou de um atendimento ineficiente nesses casos.

No caso de produtos de tecnologia mais simples, a influência dos importados chineses é maior. Embora, os fabricantes no Brasil possam oferecer produtos com melhor qualidade, os preços não são competitivos, e apesar da qualidade dos produtos chineses ser inferior, em 
muitos casos, atende à necessidade do cliente. Empresas que se encontram nesse contexto, para viabilizarem sua competitividade no mercado interno, tendem a limitar sua fabricação no Brasil e a importar cada vez mais peças e componentes de seus produtos, em especial, da China. Em outros termos, há uma tendência dessas empresas caracterizarem-se mais como "montadoras" do que como fabricantes.

\subsubsection{Concorrência externa}

A competitividade das empresas da amostra em relação aos concorrentes estrangeiros (produtos importados) foi analisada em termos de tecnologia e preço. Em termos tecnológicos, as empresas declararam se a tecnologia do concorrente externo é mais avançada, equivalente ou menos avançada. Quanto ao preço, as empresas também informaram se o praticado pelos concorrentes externos é superior, similar ou inferior ao delas.

Tabela 11a: Competitividade das empresas em relação à tecnologia para produtos importados

\begin{tabular}{lcll}
\hline $\begin{array}{c}\text { Tecnologia do } \\
\text { concorrente externo }\end{array}$ & \% da amostra & Origem da empresa & $\%$ \\
\hline Tecnologia mais avançada & $31 \%$ & Empresas nacionais & $84,6 \%$ \\
\hline & & Empresas transnacionais & $15,4 \%$ \\
Tecnologia equivalente & $31 \%$ & Empresas nacionais & $69,2 \%$ \\
\hline & & Empresas transnacionais & $30,8 \%$ \\
\hline
\end{tabular}

Fonte: Elaborado a partir de pesquisa de campo

Pela Tabela 11a é possível notar que as empresas da amostra concorrem com produtos importados em vários graus de conteúdo tecnológico.

Pode-se verificar que há um primeiro grupo de empresas que compõem $31 \%$ da amostra que concorre com produtos importados que incorporam tecnologias mais avançadas. Para um segundo grupo, com também $31 \%$ de empresas, a tecnologia dos produtos importados é considerada equivalente. E, para as demais empresas da amostra (38\%), que compõem o terceiro grupo, a tecnologia dos produtos estrangeiros, que concorrem em seus nichos de mercado no Brasil, é considerada, de maneira geral, inferior a que elas produzem. No entanto, é importante destacar que, dentre as empresas fabricantes no Brasil que consideram os produtos estrangeiros mais avançados tecnologicamente, 84,6 \% são de origem nacional e $15,4 \%$, transnacionais. 
No caso de tecnologias equivalentes, um elevado percentual de empresas nacionais também configura. Dentre o total de fabricantes que considera a tecnologia dos produtos importados equivalente aos seus, 69,2\% são empresas nacionais. E por fim, dentre as empresas que consideram a tecnologia de produtos importados menos avançadas, 43,7\% são empresas nacionais e $56,3 \%$, transnacionais.

As empresas nacionais da amostra, de maneira geral, apresentam menor grau de competitividade, em termos tecnológicos, quando concorrem com produtos importados. Do total de empresas nacionais representantes da amostra, para uma parcela de $74,1 \%$ os produtos importados concorrem no mercado nacional apresentando tecnologias mais avançadas ou equivalentes. No caso das empresas transnacionais, uma parcela menor é verificada. Do total da amostra, somente para $13,3 \%$ das empresas transnacionais os produtos importados apresentam tecnologia superior. Vale dizer, em outros termos, que 86,7\% das empresas transacionais concorrem com produtos importados com tecnologia inferior ou equivalente.

Em relação à concorrência por preços, pela Tabela 11b, verificam-se dois grandes grupos de empresas, que juntos compreendem mais de $90 \%$ da amostra. Para um primeiro grupo, composto por $45,2 \%$, as empresas são mais competitivas em termos de preço; e para um segundo grande grupo, com 47,6\% de empresas, observa-se o oposto, ou seja, o preço dos produtos importados são inferiores, e competitividade nesse fator é menor.

Tabela 11b: Competitividade das empresas em relação ao preço para produtos importados

\begin{tabular}{lcll}
\hline $\begin{array}{l}\text { Preço do } \\
\text { concorrente externo }\end{array}$ & \% da amostra & Origem da empresa & $\%$ \\
\hline \multirow{2}{*}{ Preço superior } & $45,2 \%$ & Empresas nacionais & $57,9 \%$ \\
\hline & & Empresas transnacionais & $42,1 \%$ \\
\hline Preço similar & $7,1 \%$ & Empresas nacionais & $100 \%$ \\
\hline & & Empresas transnacionais & $0 \%$ \\
\hline & & Empresas nacionais & $65,0 \%$ \\
\hline
\end{tabular}

Fonte: Elaborado a partir de pesquisa de campo

No entanto, vale notar que no caso das empresas mais competitivas por preço, diante dos produtos importados, $57,9 \%$ são nacionais e $42,1 \%$, nacionais, enquanto que, para o grupo de empresas com menor competitividade em preço, a maior parcela é composta por empresas nacionais, correspondendo a aproximadamente dois terços do total relativo ao grupo. 
Nota-se que as empresas transnacionais, comparadas às empresas nacionais, competem melhor em preço diante da concorrência de produtos importados. Vale destacar, entretanto, que essa diferença, se justifica, em boa parte, pelo conteúdo tecnológico oferecido pelas empresas. As empresas nacionais, de maneira geral, fornecem produtos mais simples, de menor conteúdo tecnológico, em relação às empresas transnacionais fabricantes no Brasil, e tal condição favorece a entrada de produtos importados com preços mais competitivos, já que essas empresas estrangeiras produzem em maior escala e com custos menores, em especial, as empresas chinesas.

É importante destacar, que tanto em relação à tecnologia quanto a preço, as empresas nacionais são menos competitivas, comparadas com as empresas transnacionais instaladas no Brasil. Tal contexto mostra a clara necessidade de se investir mais em desenvolvimento tecnológico e na capacitação tecnológica das empresas nacionais.

\subsubsection{Conhecimento e monitoramento do ambiente externo}

O conhecimento e o monitoramento do ambiente externo estão relacionados aos mecanismos de defesa comercial. O conhecimento do grau de satisfação do produto pelos clientes, o conhecimento dos principais concorrentes, bem como o monitoramento dos mercados nacional e internacional contribuem para a identificação de ameaças e oportunidades e dos pontos fortes e fracos das empresas.

De acordo com a Tabela 12, as empresas apresentam, de maneira geral, bons índices de conhecimento do grau de satisfação do produto pelos clientes. O mesmo ocorre em relação ao conhecimento de seus principais concorrentes. No entanto, o monitoramento do mercado nacional e internacional apresentam índices médio e baixo, respectivamente.

Tabela 12: Conhecimento e monitoramento do ambiente externo

\begin{tabular}{lcc}
\hline Conhecimento e monitoramento do ambiente externo & Média & $\begin{array}{c}\text { Coeficiente de } \\
\text { Variação (CV) }\end{array}$ \\
\hline Conhecimento do grau de satisfação do produto pelos clientes & 5,6 & $16,57 \%$ \\
Conhecimento dos principais concorrentes & 5,3 & $24,25 \%$ \\
Monitoramento constante do mercado nacional & 4,6 & $38,54 \%$ \\
Monitoramento constante do mercado internacional & 3,3 & $63,75 \%$ \\
\hline
\end{tabular}

Fonte: Elaborado a partir de pesquisa de campo

As empresas, por atenderem fundamentalmente o mercado nacional concentram a busca de informações em mercados locais. O monitoramento é constante para $60 \%$ das empresas e para 
$20 \%$ o monitoramento é considerado muito baixo. Quanto ao monitoramento do mercado internacional, há uma variação maior entre os respondentes. Pode-se observar uma parcela significativa de empresas (aproximadamente 58\%) que apresentam índices baixos de monitoramento constante e outra parcela, também importante (42\%), que monitora constantemente o mercado nacional. Isso pode ser observado pelo elevado coeficiente de variação apresentado pelas empresas. Para as empresas transnacionais o monitoramento do mercado internacional é realizado pela matriz, cabendo à subsidiária somente a do mercado nacional.

\subsubsection{Finalidade das atividades de inovação}

No que tange à finalidade das atividades de inovação, foram analisados inicialmente o foco de suas atividades. Buscou-se identificar se o propósito da inovação se concentra em (a) substituir um produto importado ou em (b) oferecer um produto diferente ao encontrado no mercado.

A fim de complementar tais objetivos, buscou-se identificar o foco dos projetos de inovação em termos de mercado e produto. Em termos de mercado foram avaliados os objetivos em (a) manter o mercado, (b) ampliar o mercado, e (c) abrir novos mercados.

Em relação aos produtos, buscou avaliar os objetivos dos projetos de inovação quanto à (a) substituição de produtos obsoletos, (b) ampliação das linhas de produtos atuais, (c) abertura de novas linhas de produtos, e (d) manutenção da atual linha com melhoria de qualidade.

Os resultados são apresentados nas Tabela 13,14 e 15, a seguir.

Tabela 13: Finalidade das atividades de inovação

\begin{tabular}{lcc}
\hline Finalidade das atividades de inovação & Frequência & \% \\
\hline Substituir um produto importado & 8 & $18,2 \%$ \\
$\begin{array}{l}\text { Oferecer um produto diferente do mercado existente } \\
\begin{array}{l}\text { Substituir um produto importado e oferecer um produto diferente do } \\
\text { mercado existente }\end{array}\end{array}$ & 33 & $75,0 \%$ \\
Total & 44 & $6,8 \%$ \\
\hline
\end{tabular}

Fonte: Elaborado a partir de pesquisa de campo

Para a grande maioria das empresas o principal objetivo dos projetos de inovação está voltado para a oferta de produtos diferentes aos encontrados no mercado. A substituição por um produto importado representa apenas $18,2 \%$ dos casos. Este baixo índice deve-se ao fato de que para a maioria das empresas o produto oferecido apresenta um grau de customização 
muito alto, são projetos específicos que atendem necessidades específicas do cliente. Em apenas 3\% das empresas ambos os objetivos são referidos.

Vale notar que no caso de o objetivo da inovação ser somente a substituição por um produto importado todas as empresas são nacionais. As empresas transnacionais quando tem o foco na substituição de importados, também focam na diferenciação no mercado existente. Isso ocorre pois as empresas transnacionais, em grande parte, apresentam tanto produtos com grau menor de customização quanto aqueles mais padronizados. Os produtos com grau de padronização maior alcançam maior escala de vendas e podem ser comercializados em diferentes regiões.

Em termos de mercado, os projetos de inovação, conforme a Tabela 14, visam fundamentalmente ampliar o mercado atual $(72,5 \%)$ e abrir novos mercados $(47,5 \%)$. Pouco mais de um terço das empresas $(35 \%)$ tem por objetivo apenas manter o mercado atual.

Tabela 14: Objetivos dos projetos de inovação em relação ao mercado

\begin{tabular}{lcc}
\hline Objetivos dos projetos de inovação em relação ao mercado & Frequência & \% \\
\hline Manter o mercado atual & 12 & $30,0 \%$ \\
Ampliar o mercado atual & 29 & $72,5 \%$ \\
Abrir novo mercado & 19 & $47,5 \%$ \\
Manter e ampliar o mercado atual & 5 & $12,5 \%$ \\
Ampliar o mercado atual e abrir novo mercado & 16 & $40,0 \%$ \\
Manter o mercado atual e abrir novos mercados & 1 & $2,5 \%$ \\
\hline
\end{tabular}

Fonte: Elaborado a partir de pesquisa de campo

Vale destacar, entretanto, que as empresas que buscam não apenas a manutenção do mercado representam apenas $15 \%$ da amostra. Em outros termos, vale dizer que as empresas que concentram esforços em manter o mercado atual encontram grandes barreiras e dificuldades para competir nos mesmos. Esta condição inibe o desenvolvimento de projetos voltados para ampliação e criação de novos mercados de atuação, já que manter o mercado atual passa a ser a prioridade. Por outro lado, as empresas que buscam abrir novos mercados, além de ampliálos, representam $40 \%$ da amostra. Neste caso, as empresas que buscam ampliar e abrir novos mercados já apresentam uma boa competitividade nos mercados atuais. Tal condição, ao contrário da anterior, favorece o direcionamento dos projetos de inovação para a ampliação e busca de novos mercados.

Em relação ao produto, de acordo com a Tabela 15, a ampla maioria das empresas pesquisadas tem como objetivo principal a ampliação das linhas de produtos $(72,5 \%)$, seguido 
pela manutenção da atual linha com melhoria de qualidade $(45,5 \%)$. Vale destacar que somente $10 \%$ das empresas têm por objetivo unicamente manter a atual linha com melhoria de qualidade.

Tabela 15: Objetivos dos projetos de inovação em relação ao produto

\begin{tabular}{lcc}
\hline Objetivos dos projetos de inovação em relação ao produto & Frequência & $\%$ \\
\hline Substituição de produtos obsoletos & 0 & $0 \%$ \\
Manter atual linha com melhoria de qualidade & 18 & $45,0 \%$ \\
Ampliar linhas de produtos atuais & 29 & $72,5 \%$ \\
Abrir novas linhas de produtos & 17 & $42,5 \%$ \\
Manter a atual linha com melhoria de qualidade e abrir novas linhas de produtos e & 5 & $12,5 \%$ \\
Manter atual linha com melhoria da qualidade e ampliar linha de produtos atuais. & 9 & $22,5 \%$ \\
Ampliar linhas de produtos atuais e abrir novas linhas de produtos & 8 & $20,0 \%$ \\
\hline
\end{tabular}

\section{Fonte: Elaborado a partir de pesquisa de campo}

É importante observar que 42,5\% das empresas apresentam como objetivo principal a abertura de novas linhas de produtos, combinados com outros objetivos.

Outra análise importante é determinar para cada objetivo dos projetos de inovação, relacionados ao mercado, o foco em relação ao produto. A Tabela 16 mostra a relação entre os dois objetivos.

Tabela 16: Objetivos de mercado e objetivos de produto nos projetos de inovação

\begin{tabular}{lccc}
\hline $\begin{array}{c}\text { Objetivos dos projetos de } \\
\text { inovação em relação ao } \\
\text { mercado }\end{array}$ & \multicolumn{2}{c}{ Objetivos dos projetos de inovação em relação ao produto } \\
\cline { 2 - 4 } & $\begin{array}{c}\text { Ampliar linhas de } \\
\text { produtos atuais }\end{array}$ & $\begin{array}{c}\text { Abrir novas linhas } \\
\text { de produtos }\end{array}$ & $\begin{array}{c}\text { Manter atual linha com } \\
\text { melhoria de qualidade }\end{array}$ \\
\hline Manter o mercado atual & 10 & 2 & 6 \\
\hline Ampliar o mercado atual & $25 \%$ & $5 \%$ & $15 \%$ \\
\hline \multirow{2}{*}{\begin{tabular}{c} 
Abrir novos mercados \\
\cline { 2 - 4 }
\end{tabular}} & 21 & 14 & 14 \\
\hline
\end{tabular}

Fonte: Elaborado a partir de pesquisa de campo

Pela Tabela 16, podemos observar, conforme destaco anteriormente, que ampliar o mercado atual é o principal objetivo das empresas em relação aos projetos de inovação. Abrir novos mercados surge como o segundo maior objetivo, seguido da manutenção de mercado. 
Em todos os três objetivos destacados acima, a ampliação das linhas de produtos atuais é o que mais se destaca. Em outros termos, pode-se afirmar que as empresas, de maneira geral, têm como objetivo principal ampliar o mercado atual ampliando as linhas de produtos atuais.

\subsection{Fatores internos}

\subsubsection{Recursos}

a) Recursos humanos: Capacitação de pessoal envolvido na produção e no desenvolvimento de produtos

A avaliação da capacitação de pessoal está relacionada ao grau de qualificação dos engenheiros nos processos de fabricação, no planejamento e controle da produção, na área da qualidade, e para as atividades de inovação, como o de desenvolvimento de produto. Buscouse também identificar a necessidade de mais profissionais da engenharia.

Gráfico 9: Capacitação para produção e inovação

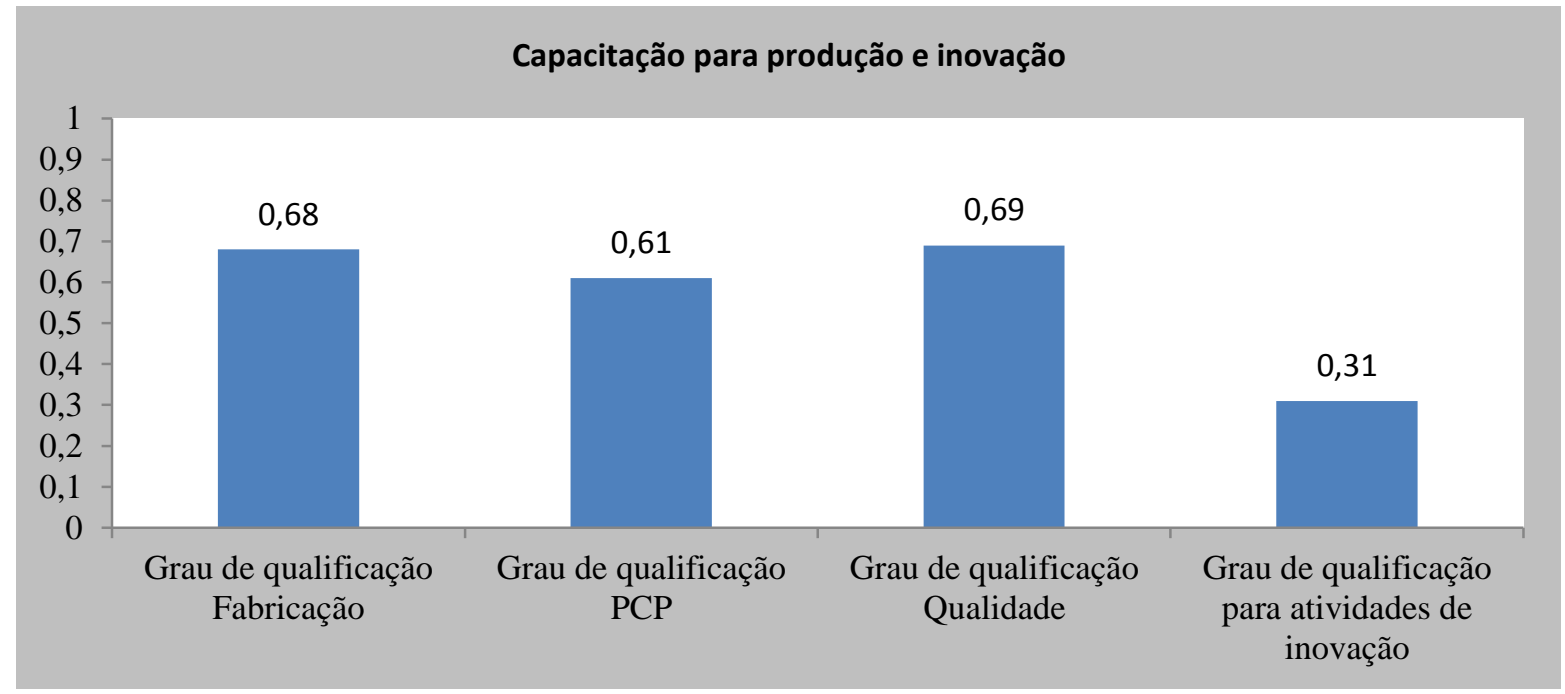

Fonte: Elaborado a partir de pesquisa de campo

Pelo Gráfico 9 é possível observar que o grau de qualificação apontado pelas empresas no que se refere à fabricação, produção e qualidade, é considerado mediano. Para $61,5 \%$ das empresas pesquisadas o grau de qualificação para a engenharia de fabricação é considerado como bom, haja vista a necessidade atual. Para o setor de PCP, aproximadamente 55\% das empresas possuem profissionais com grau de qualificação considerado como bom. Para 67\% das empresas, a área da qualidade apresenta um quadro de pessoal com qualificação considerada satisfatória para os atuais nichos de mercado atendidos.

Os funcionários ligados à engenharia apresentam uma base satisfatória de conhecimentos e competências. Na maioria das empresas a rotatividade de pessoal é considerada pequena, o 
que gera experiência e competências específicas necessárias para atender as especificidades do produto. Em muitas empresas, em especial, as de pequeno e médio portes, são os mesmos profissionais que atuam na engenharia de fabricação, de produção e de projetos de desenvolvimento de produtos. Em empresas de grande porte a dedicação dos profissionais é mais específica e voltada para uma determinada área de atuação.

Vale destacar que o grau medido é em relação à necessidade atual e que em muitas empresas há uma participação grande de técnicos de nível médio exercendo tais atividades. No entanto, quando questionadas sobre a necessidade de mais engenheiros, a área de PCP é a que mais se destaca. Para mais da metade das empresas $(51 \%)$ há a necessidade de contratação de pessoal para melhor organização do planejamento e controle da produção, seguidos pela área de fabricação (41\%) e qualidade (31\%), conforme mostrado no Gráfico 10.

A necessidade, relativamente pequena na área da qualidade denota um nível satisfatório de atendimento às exigências de conformidade de produto nos nichos atuais de atuação. Em outros termos, a maioria das empresas oferece produtos com qualidade relativamente competitiva.

A necessidade de pessoal na área de PCP visa à redução do custo de produção e aumento da produtividade, considerados elevados pela maioria das empresas. Em outros temos, as empresas, em sua maioria, fundamentalmente têm construído capacidades tecnológicas para atividades de uso ou operação de tecnologias e de sistemas de produção existentes.

Gráfico 10: Necessidade de mão-de-obra qualificada no setor de engenharia de processo

\section{Necessidade de engenheiros}

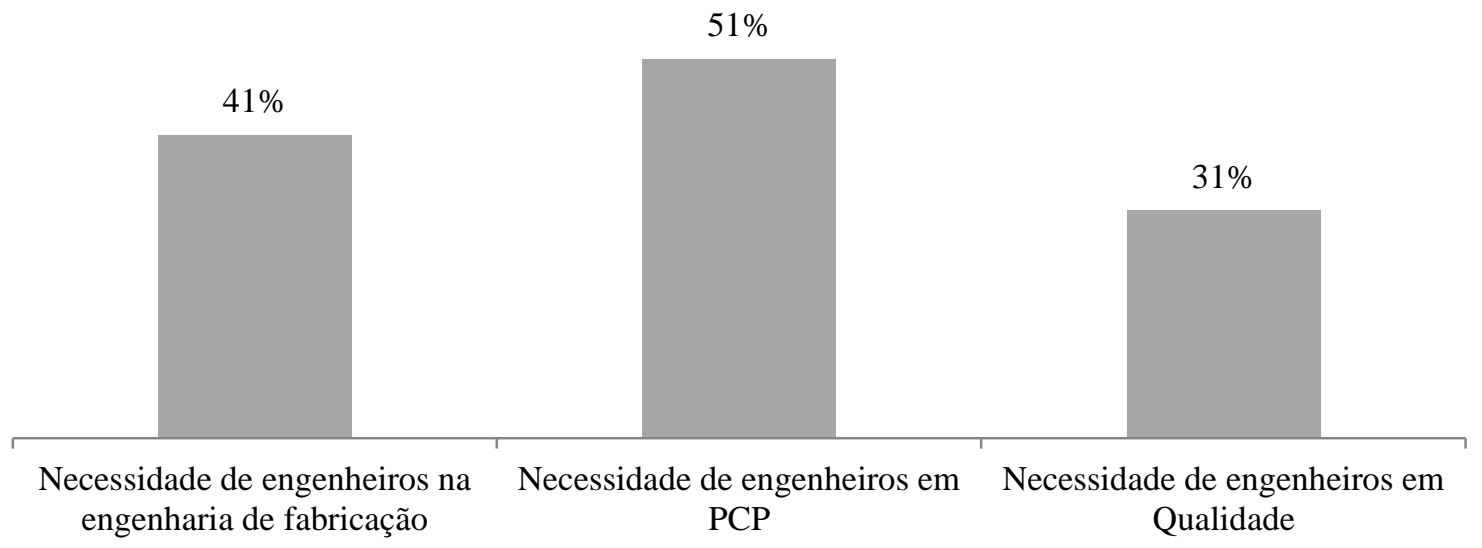

Fonte: Elaborado a partir de pesquisa de campo

As empresas declaram que há uma grande dificuldade de se encontrar profissionais qualificados no mercado. Na maioria das vezes a atividade produtiva exige conhecimentos 
específicos, devido ao elevado grau de especificidade, o que gera, em muitos casos, a necessidade de formação interna dos recursos humanos técnicos. O sistema organizacional, conforme enfatizado por Figueiredo (2009), é caracterizado por ser tácito e único a empresas específicas.

É importante destacar que em relação à qualificação da mão-de-obra cabe uma consideração que se refere aos tipos de necessidade. Tem-se a mão-de-obra para as atividades de operação, que compreendem ocupações rotineiras de planejamento, controle e produção, e aquela voltada às atividades de desenvolvimento, que abrangem projetos, pesquisa e desenvolvimento de produtos. Para as empresas que competem em mercados com maior exigência tecnológica há uma carência de mão-de-obra especializada e qualificada tanto para as atividades operacionais quanto para as de desenvolvimento. A escassez de mão-de-obra nesses casos deve-se, em grande parte, pelo alto grau de especialização e heterogeneidade apresentado pelos produtos.

A infraestrutura educacional, por sua vez, foca mais capacitação de profissionais voltados para as atividades operacionais do que para as atividades de desenvolvimento de produtos e inovação tecnológica. Aliada a escassez, o alto custo configura como outro componente de dificuldade; para muitas empresas o custo da mão-de-obra representa uma grande parcela do custo total da empresa. Diante disso, as empresas investem na formação de seus próprios funcionários a fim de melhorar sua qualificação. No caso de empresas transnacionais o nível de qualificação desejado é adquirido externamente, por meio de treinamentos e cursos de capacitação realizados nas matrizes.

b) Recursos físicos: máquinas e equipamentos

Os equipamentos constituem uma dimensão diretamente ligada à engenharia de processo e de produto. É o capital físico da empresa. Do aprimoramento dos métodos de produção a inovações de processo e de produto, os equipamentos tem papel fundamental, pois é por meio deles que tais mudanças são apoiadas em sua realização. A atualização de equipamentos beneficiam diretamente a qualidade dos produtos, a produtividade, a flexibilidade da produção e o fornecimento adequado de bens e serviços.

Do total de empresas pesquisadas, mais da metade $(55,0 \%)$ declararam não precisar de substituição de seus principais equipamentos utilizados na manufatura (Tabela). Nesses casos quase metade das empresas $(47,5 \%)$ possuem máquinas e equipamentos modernos adquiridos há menos de cinco anos. Entretanto, $45 \%$ das empresas possuem uma parcela de máquinas e 
equipamentos com grau de atualização tecnológica defasada, necessitando de substituição. Para 17,5\% das empresas suas principais máquinas e/ou equipamentos estão obsoletos e necessitam de substituição. Nesses dois últimos casos há uma grande carência de equipamentos providos de automação eletrônica. A heterogeneidade da amostra revela que há um dinamismo tecnológico alto em algumas empresas e baixo em outras.

Gráfico 11: Resultados pretendidos com a aquisição de novos equipamentos

\begin{tabular}{lcc}
\hline Resultados pretendidos & QTD & \% \\
\hline Total de empresas sem necessidade de substituição & 22 & $55 \%$ \\
\hline Total de empresas com necessidade de substituição & 18 & $45 \%$ \\
\hline Redução de custo operacional & 12 & $67 \%$ \\
\hline Simples substituição por tempo de uso & 4 & $22 \%$ \\
\hline Aumento de escala produtiva & 10 & $56 \%$ \\
\hline
\end{tabular}

Fonte: Elaborado a partir de pesquisa de campo

Conforme Tabela 17, o principal resultado pretendido com a aquisição de novos equipamentos é para a redução do custo operacional e aumento de escala produtiva, representando $67 \%$ e $56 \%$ das empresas. A simples substituição por tempo de uso é prendida em apenas $22 \%$ dos casos. Vale destacar, no entanto, que há empresas que têm por objetivo a redução do custo operacional e também o aumento de escala, representando $33 \%$.

É importante salientar os esforços tecnológicos das empresas que investiram em novas máquinas e equipamentos nos últimos 5 anos. Em boa parte, a principal motivação desses investimentos deu-se pela perspectiva positiva de crescimento econômico nacional aliado a uma demanda e consumo internos maiores.

Por outro lado, tais investimentos não foram considerados muito positivos por muitas empresas, pois apesar das vantagens oferecidas pelas novas máquinas e equipamentos, em termos de maior produção e melhor qualidade dos produtos, as políticas cambiais e comerciais praticadas não foram capazes de proteger o setor, considerado um dos mais expostos à concorrência externa. Apesar de a participação do mercado ter aumentado ou se mantido para a maioria das empresas, o resultado não foi o esperado. 
c) Recursos financeiros: capital de giro e investimentos para projetos

Em relação aos recursos financeiros para as operações diárias ou rotineiras, nota-se uma heterogeneidade nas condições das empresas, refletida no elevado coeficiente de variação $(56,83 \%)$ apresentado. O capital de giro, conforme Tabela 17 , não se apresenta como variável significativa em termos de obstáculos para o desenvolvimento das empresas, em 57,5\% das empresas. Nesse caso, tanto para as empresas nacionais como para as transnacionais, as operações diárias são sustentadas por recursos financeiros próprios e não representam uma dificuldade maior.

Tabela 17: Capital de giro como obstáculo ao crescimento das empresas

\begin{tabular}{lccccccc}
\hline \multicolumn{7}{c}{ Grau de concordância } \\
\hline Capital de giro & $\mathbf{1}$ & $\mathbf{2}$ & $\mathbf{3}$ & $\mathbf{4}$ & $\mathbf{5}$ & $\mathbf{6}$ & $\mathbf{7}$ \\
\hline \% total de empresas & $20,0 \%$ & $20,0 \%$ & $17,5 \%$ & $12,5 \%$ & $7,5 \%$ & $17,5 \%$ & $5,0 \%$ \\
\hline Empresas Nacionais & $14,8 \%$ & $22,2 \%$ & $18,5 \%$ & $7,4 \%$ & $7,4 \%$ & $22,2 \%$ & $7,4 \%$ \\
\hline Empresas Transnacionais & $26,7 \%$ & $20,0 \%$ & $13,3 \%$ & $26,7 \%$ & $6,7 \%$ & $6,7 \%$ & $0 \%$ \\
\hline
\end{tabular}

Fonte: Elaborado a partir de pesquisa de campo

Entretanto, para aproximadamente um terço das empresas (30\%) esse fator é considerado um obstáculo importante e para 12,5\% um obstáculo mediano. Nesse conjunto, as empresas nacionais apresentam um nível de dificuldade maior em relação às transnacionais.

É importante destacar que em relação aos investimentos em projetos, em 87,5\% da amostra eles têm como fonte principal a própria empresa, e o nível de dificuldade para dispor desse capital é considerado elevado para 53\% das empresas, mediano para $17 \%$ e baixo, para $30 \%$ da composição da amostra.

Quanto ao acesso a financiamentos para projetos, observa-se que também há uma heterogeneidade nas condições das empresas da amostra. Para uma parcela significativa de empresas $(59,5 \%)$ não há uma dificuldade significativa em obtê-los. Mas, para aproximadamente um terço das empresas (30,9\%) essa dificuldade se apresenta como expressiva. Nesse caso, ocorre uma diferença entre empresas nacionais e transnacionais. De acordo com a Tabela, para somente $7 \%$ das empresas transnacionais a obtenção de financiamento para projetos é um fator obstáculo para o desenvolvimento da organização, entretanto, para as empresas nacionais essa parcela é mais significativa, sendo $42 \%$ das 
empresas declarando dificuldades para a obtenção de financiamentos para o desenvolvimento de seus projetos.

Outro aspecto importante a ser destacado é o porte das empresas. Considerando o total de empresas que apresentam dificuldades significativas em obter financiamentos para projetos, aproximadamente $61 \%$ são de pequeno porte, $31 \%$ de médio porte, e apenas $8 \%$ de grande porte. No entanto, vale observar que, conforme Tabela 18, ao se considerarem as empresas de mesmo porte, dentre aquelas de pequeno porte há uma parcela significativa (47\%) que não apresenta maiores dificuldades em obter financiamentos para projetos. Para as empresas de médio porte, essa parcela aumenta para aproximadamente $65 \%$ e, para as de grande porte, $75 \%$.

Tabela 18: Grau de concordância da obtenção de financiamento por origem da empresa

\begin{tabular}{lccccccc}
\hline & \multicolumn{7}{c}{ Dificuldade para obtenção de financiamentos para projetos } \\
\hline Origem da Empresa & $\mathbf{1}$ & $\mathbf{2}$ & $\mathbf{3}$ & $\mathbf{4}$ & $\mathbf{5}$ & $\mathbf{6}$ & $\mathbf{7}$ \\
\hline \% total de empresas & $26,2 \%$ & $19,0 \%$ & $14,3 \%$ & $9,5 \%$ & $0 \%$ & $19,0 \%$ & $11,9 \%$ \\
\hline Empresas Nacionais & $23 \%$ & $19 \%$ & $12 \%$ & $4 \%$ & $0 \%$ & $23 \%$ & $19 \%$ \\
\hline Empresas Transnacionais & $36 \%$ & $14 \%$ & $21 \%$ & $21 \%$ & $0 \%$ & $7 \%$ & $0 \%$ \\
\hline Pequeno porte & $5,9 \%$ & $23,5 \%$ & $17,6 \%$ & $5,9 \%$ & $0 \%$ & $23,5 \%$ & $23,5 \%$ \\
\hline Médio porte & $35,3 \%$ & $17,6 \%$ & $11,8 \%$ & $11,8 \%$ & $0 \%$ & $17,6 \%$ & $5,9 \%$ \\
\hline Grande porte & $50,0 \%$ & $12,5 \%$ & $12,5 \%$ & $12,5 \%$ & $0 \%$ & $12,5 \%$ & $0,0 \%$ \\
\hline
\end{tabular}

Fonte: Elaborado a partir de pesquisa de campo

Portanto, verifica-se que na medida em que o porte das empresas aumenta a dificuldade em obter acesso para financiamentos de projetos, diminui. Essa correlação pode ser confirmada ao ponderar-se o coeficiente de correlação de Spearman, calculado em -0,386 para um nível de significância estatística de $\mathrm{p}<0,05$. Embora a força de associação seja pequena, conforme classificação sugerida em Hair Jr et al. (2009), ela é considerada definida.

\subsubsection{Engenharia da Qualidade}

Em relação às atividades no setor da qualidade, o desempenho apresentado pelas empresas mostram diferenças substanciais para as nacionais e transnacionais.

Para as empresas transnacionais, de maneira geral, questões que envolvem a qualidade do produto, em termos de conformidade técnica, não apresentam problemas que afetam sua competitividade (Tabela 19). Todas as empresas são certificadas pela ISO 9000. Outras 
normas estão presentes, as quais se destacam a ISO 14000, sobre gestão ambiental; OHSAS 18000, sobre segurança e saúde ocupacional; e ISO 26000, sobre responsabilidade social.

Para as empresas nacionais, pouco mais de um terço $(38,5 \%)$ possui certificação ISO 9000, o que representa apenas $25 \%$ das empresas que compõem as amostra. O controle da qualidade é realizado em sua maior parte por técnicos de nível médio, com programas de qualidade pouco formalizados.

Quanto ao controle estatístico de processo, está presente em $86 \%$ das empresas transnacionais, e para $71 \%$ o desempenho dessa atividade para o resultado do produto é considerado bom. Além do controle estatístico de processo, outras técnicas para melhoria e desempenho da produção estão presentes, tais como o Just In Time e o Lean Six Sigma, ainda que para poucas empresas da amostra.

Quanto aos programas de treinamento em qualidade, estão presentes em 50\% das empresas nacionais e em $93 \%$ das transnacionais. No entanto, o desempenho desses programas é considerado bom por apena $57 \%$ das empresas transnacionais e por $23 \%$ das empresas nacionais. Se considerarmos o total de empresas da amostra, para somente $35 \%$ das empresas o desempenho nesse aspecto é considerado bom; o que sugere que os treinamentos em programas de qualidade precisam ser mais bem atendidos e aprimorados.

Tabela 19: Atividades no setor da qualidade

\begin{tabular}{|c|c|c|c|c|c|c|}
\hline \multirow{2}{*}{ Qualidade } & \multicolumn{3}{|c|}{ Empresas Nacionais } & \multicolumn{3}{|c|}{ Empresas Transnacionais } \\
\hline & $\begin{array}{c}\text { Não } \\
\text { possui }\end{array}$ & Possui & $\begin{array}{c}\text { Desempenho } \\
\text { bom }\end{array}$ & $\begin{array}{c}\text { Não } \\
\text { possui }\end{array}$ & Possui & $\begin{array}{c}\text { Desempenho } \\
\text { bom }\end{array}$ \\
\hline $\begin{array}{lll}\text { Controle } & \text { Estatístico } & \mathrm{de} \\
\text { Processo } & & \\
\end{array}$ & $65,0 \%$ & $35,0 \%$ & $19,0 \%$ & $14,0 \%$ & $86,0 \%$ & $71,0 \%$ \\
\hline$\%$ Total da amostra & $42,5 \%$ & $22,5 \%$ & $12,5 \%$ & $5,0 \%$ & $30,0 \%$ & $25,0 \%$ \\
\hline Programas de treinamento & $50,0 \%$ & $50,0 \%$ & $23,0 \%$ & $7,0 \%$ & $93,0 \%$ & $57,0 \%$ \\
\hline$\%$ Total da amostra & $32,5 \%$ & $32,5 \%$ & $15,0 \%$ & $2,5 \%$ & $32,5 \%$ & $20,0 \%$ \\
\hline Certificação de Qualidade & $61,5 \%$ & $38,5 \%$ & ---- & $7,0 \%$ & $100 \%$ & ---- \\
\hline$\%$ Total da amostra & $40,0 \%$ & $25,0 \%$ & --- & $2,5 \%$ & $32,5 \%$ & --- \\
\hline
\end{tabular}

Fonte: Elaborado a partir de pesquisa de campo

Em resumo, as empresas transnacionais possuem um desempenho relativamente bom no que se refere às questões sobre qualidade. Seus produtos tem boa aceitação no mercado, possibilitando uma competição nos padrões de concorrência por diferenciação. 
No caso das empresas nacionais, para os nichos de mercado em que atua a maioria das empresas, o nível de qualidade dos produtos oferecidos atende às exigências de seus clientes, que são em grande parte constituídos por empresas de pequeno porte. Por outro lado, é importante enfatizar que novos entrantes, em especial chineses, têm competido com produtos em níveis de qualidade cada vez melhores. Essa recente mudança tem feito com empresas que possuem níveis de qualidade mínimos passem a identificar a necessidade de realizar novos investimentos em gestão e controle da qualidade. Essas diferenças entre empresas nacionais e transnacionais são refletidas no grau de dificuldade que representam para seu próprio desenvolvimento.

De acordo com a Tabela 20, é possível identificar concordâncias e discordâncias representativas desse fator como obstáculo ao desenvolvimento das empresas, refletidas também pelo alto coeficiente de variação mostrado.

Tabela 20; Obstáculos para o desenvolvimento da empresa: produção com qualidade por origem da empresa

\begin{tabular}{lccccccc}
\hline \multicolumn{7}{c}{ Grau de concordância } \\
\hline Origem da Empresa & $\mathbf{1}$ & $\mathbf{2}$ & $\mathbf{3}$ & $\mathbf{4}$ & $\mathbf{5}$ & $\mathbf{6}$ & $\mathbf{7}$ \\
\hline Empresas Nacionais & $8 \%$ & $12 \%$ & $12 \%$ & $12 \%$ & $31 \%$ & $27 \%$ & $0 \%$ \\
\hline Empresas Transnacionais & $7 \%$ & $29 \%$ & $21 \%$ & $29 \%$ & $0 \%$ & $14 \%$ & $0 \%$ \\
\hline
\end{tabular}

Fonte: Elaborado a partir de pesquisa de campo

Para 42,5\% das empresas, há o reconhecimento desse fator como obstáculo importante ao desenvolvimento da empresa, e para $40 \%$, uma importância pequena. Para o primeiro grupo de empresas há uma forte presença de empresas nacionais, enquanto no segundo grupo, uma parcela maior representada pelas empresas transnacionais, conforme mostrado na Tabela 21 .

\subsubsection{Engenharia de Produto}

A análise da engenharia de produto compreendeu os esforços tecnológicos para a inovação, os quais referem-se às atividades voltadas para a melhoria do conteúdo tecnológico, para o desenvolvimento e aperfeiçoamento de novos produtos e processos.

Procurou-se identificar o esforço empreendedor contínuo em termos de dispêndios para as atividades de pesquisa e desenvolvimento, e o grau de novidade atribuído ao produto, partir dessas atividades. 
De acordo com a Tabela 21, para 38,6\% de empresas da amostra os dispêndios ao longo dos últimos cinco anos aumentaram. Para cerca um terço das empresas os gastos foram mantidos nesse período. Somente em 15,9\% das empresas os dispêndios diminuíram e para 11,4\% das empresas, oscilaram ao longo dos últimos cinco anos.

Tabela 21: Dispêndios em P\&D

\begin{tabular}{lcc}
\hline Dispêndios em P\&D & Frequência & \% \\
\hline Diminuiu & 7 & $15,9 \%$ \\
Manteve & 15 & $34,1 \%$ \\
Cresceu & 17 & $38,6 \%$ \\
Oscilou & 5 & $11,4 \%$ \\
Total & 44 & $100 \%$ \\
\hline
\end{tabular}

Fonte: Elaborado a partir de pesquisa de campo

É importante destacar que os investimentos em desenvolvimento de produtos apesar de apresentarem um positivo crescimento e manutenção, ainda são insuficientes ou parcialmente insuficientes para as necessidades das empresas.

Tabela 22: Investimentos na área Tecnológica

\begin{tabular}{lcc}
\hline Investimentos & Frequência & $\%$ \\
\hline Insuficiente & 14 & $31,8 \%$ \\
Parcialmente Suficiente & 20 & $45,5 \%$ \\
Suficiente & 10 & $22,7 \%$ \\
Total & 44 & $100 \%$ \\
\hline
\end{tabular}

Fonte: Elaborado a partir de pesquisa de campo

Conforme a Tabela 22, em 77,3\% dos casos os investimentos na área tecnológica são insuficientes ou parcialmente insuficientes. Somente para aproximadamente um quarto das empresas $(22,7 \%)$ os investimentos são declarados como suficientes.

Quanto ao direcionamento das atividades de inovação, conforme a Tabela 23, pode-se considerar que para pouco mais da metade das empresas (52,3\%) o investimento das atividades de inovação são voltadas exclusivamente para a realização de melhoria, ou seja, os projetos não visam o desenvolvimento de novos produtos, mas adaptações ou inovações de caráter pontual. No entanto, uma parcela também significativa da amostra $(47,7 \%$ das empresas) apresenta atividades direcionadas para o desenvolvimento de novos produtos. 
Tabela 23: Direcionamento das atividades de inovação

\begin{tabular}{lcc}
\hline Direcionamento das atividades & Frequência & \% Total \\
\hline Realização de melhorias & 23 & $52,3 \%$ \\
Realização de melhorias e desenvolvimento de novos produtos & 21 & $47,7 \%$ \\
Total & 44 & $100 \%$ \\
\hline
\end{tabular}

Fonte: Elaborado a partir de pesquisa de campo

É importante frisar que em 82,5\% das empresas a área de Planejamento e Desenvolvimento de produtos não é estruturada, ou seja, não há profissionais da engenharia e áreas afins com atividades específicas, voltadas ao desenvolvimento de produtos, nem infraestrutura física (máquinas, equipamentos, laboratórios) para essa finalidade. Dentre as empresas que possuem uma estrutura de P\&D, 57\% são empresas transnacionais e $43 \%$ empresas transnacionais.

Em relação ao grau de novidade atribuído ao produto nos últimos cinco anos, conforme Tabela 24, todas as empresas realizaram algum aprimoramento em um produto existente. Nota-se que, de certa forma, há uma rotina de atividades inovativas para melhoria de produto. Uma parcela menor, mas também significativa de empresas (65\%) realizou nos últimos cinco anos inovações incrementais consideradas novas para a empresa, embora existente no mercado nacional. Nesse caso as empresas declararam que precisam acompanhar as novidades apresentadas no mercado que, geralmente, em um ciclo de até cinco anos ocorrem. Essas novidades são identificadas, em grande parte, nas feiras nacionais e internacionais do setor metal mecânico e/ou setores atendidos.

Por outro lado, pouco mais da metade das empresas pesquisadas $(52,5 \%)$ realizou inovações que antecipassem a novidade para o mercado nacional nos últimos cinco anos, e somente $10 \%$ do total o grau de novidade não foi somente para o mercado nacional, mas mundial. Para $30 \%$ das empresas, projetos foram desenvolvidos, mas sem sucesso comercial, o que demonstra esforços de inovação para se diferenciar no mercado.

Tabela 24: Grau de novidade atribuído ao produto

\begin{tabular}{|c|c|c|c|}
\hline Grau de novidade & $\%$ Total & $\begin{array}{c}\text { Empresas } \\
\text { nacionais } \\
(\%) \\
\end{array}$ & $\begin{array}{c}\text { Empresas } \\
\text { transnacionais } \\
(\%) \\
\end{array}$ \\
\hline Aprimoramento de um existente. & $100,0 \%$ & $100,0 \%$ & $100,0 \%$ \\
\hline Novo para empresa, mas já existente no mercado nacional. & $65,0 \%$ & $65,4 \%$ & $64,3 \%$ \\
\hline $\begin{array}{l}\text { Novo para o mercado nacional, mas já existente no mercado } \\
\text { mundial. }\end{array}$ & $52,5 \%$ & $42,3 \%$ & $71,4 \%$ \\
\hline Novo para o mercado mundial. & $10,0 \%$ & $3,8 \%$ & 21,4 \\
\hline $\begin{array}{l}\text { Produtos inventados, mas não lançados ou sem aceitação no } \\
\text { mercado. }\end{array}$ & $30,0 \%$ & $26,9 \%$ & $35,7 \%$ \\
\hline
\end{tabular}


Entretanto vale dizer, que os esforços das empresas nacionais são significativos, ao considerarmos as condições desfavoráveis, de mercado e concorrência, em que operam. Um importante resultado é o esforço de desenvolvimento de novos produtos para o mercado, mesmo sem o sucesso comercial esperado, presente em mais de um quarto das empresas $(26,9 \%)$.

Ao analisarmos os lançamentos entre empresas nacionais e entre as transnacionais da amostra, pode-se notar que, as transnacionais apresentam um desempenho melhor, no que se refere ao lançamento produtos no mercado com algum grau de inovação, seja ele novo para o mercado nacional, mas existente no mercado mundial, seja ele novo para o mercado mundial.

A atualização dos produtos no mercado ocorre na maioria das empresas, nacionais $(65,4 \%)$ e transnacionais, em $(64,3 \%)$.

Vale destacar, ainda, que mais da metade das empresas $(62,5 \%)$ não segue seus concorrentes no lançamento de seus produtos, conforme Tabela 25.

Tabela 25: Empresas seguidoras e não seguidoras por origem

\begin{tabular}{lllll}
\hline Origem da empresa & Participação das empresas (\%) & Sim & Não & Total \\
\hline \multirow{2}{*}{ Nacional } & $\%$ de empresas nacionais & $50,0 \%$ & $50,0 \%$ & $100,0 \%$ \\
& $\%$ do total de empresas & $32,5 \%$ & $32,5 \%$ & $65,0 \%$ \\
\hline \multirow{2}{*}{ Transnacional } & $\%$ de empresas transnacionais & $14,3 \%$ & $85,7 \%$ & $100,0 \%$ \\
& $\%$ do total de empresas & $5,0 \%$ & $30,0 \%$ & $35,0 \%$ \\
\hline \multirow{2}{*}{ Total } & $\%$ de empresas nacionais e transnacionais & $37,5 \%$ & $62,5 \%$ & $100,0 \%$ \\
\hline
\end{tabular}

Fonte: Elaborado a partir de pesquisa de campo

Pela Tabela 25 é possível verificar que do total de empresas transnacionais, a grande maioria $(85,7 \%)$ não segue outras empresas em lançamento de novos produtos. Somente $14,3 \%$ são seguidoras e representam apenas $5 \%$ do total da amostra. No caso de empresas nacionais, o número de seguidoras é maior e representa $50 \%$, o que corresponde a aproximadamente um terço $(32,5 \%)$ da amostra pesquisada.

Em termos de obstáculo para o desenvolvimento da empresa, a P\&D, de maneira geral, é pouco relacionada como fator importante. Aproximadamente um terço dos respondentes parecem não saber se as atividades de pesquisa e desenvolvimento influenciariam no desenvolvimento da empresa. 
Para mais de $40 \%$ da amostra observa-se um entendimento de que a pesquisa e desenvolvimento é pouco relacionada aos obstáculos para o crescimento da empresa. Tal resultado corrobora o direcionamento das atividades de inovação, voltadas, para 47,5\% das empresas, exclusivamente para a realização de melhoria ou adaptações às necessidades específicas, sem atividades de desenvolvimento de novos produtos.

No entanto, vale destacar que, embora somente $2,5 \%$ das empresas reconheçam plenamente que o não desenvolvimento de atividades de $P \& D$ é uma barreira para o crescimento da empresa, há um relativo entendimento da importância dessa atividade, representado por 27,5\% da amostra. Vale destacar que as considerações sobre a Pesquisa e Desenvolvimento relatadas pelas empresas nacionais e transnacionais, apresentam particularidades (Tabela 26).

Tabela 26: Obstáculo para o desenvolvimento: grau de concordância da P\&D por origem da empresa

\begin{tabular}{lccccccc}
\hline \multicolumn{8}{c}{ Grau de concordância } \\
\hline Origem da Empresa & $\mathbf{1}$ & $\mathbf{2}$ & $\mathbf{3}$ & $\mathbf{4}$ & $\mathbf{5}$ & $\mathbf{6}$ & $\mathbf{7}$ \\
\hline Empresas Nacionais & $12 \%$ & $15 \%$ & $12 \%$ & $38 \%$ & $8 \%$ & $12 \%$ & $4 \%$ \\
\hline Empresas Transnacionais & $7 \%$ & $29 \%$ & $14 \%$ & $14 \%$ & $7 \%$ & $29 \%$ & $0 \%$ \\
\hline
\end{tabular}

Fonte: Elaborado a partir de pesquisa de campo

Para 50\% das empresas transnacionais a P\&D não é considerada um obstáculo importante para seu crescimento. As atividades voltadas para novos produtos e novas tecnologias são realizadas predominantemente nas matrizes, enquanto no Brasil a estrutura é limitada a soluções rotineiras de adaptações de projetos. Sendo assim, tais atividades não apresentam relevada importância no que tange ao desenvolvimento da empresa.

No entanto é importante observar que uma parcela menor das empresas transnacionais (29\%) destina à $\mathrm{P} \& \mathrm{D}$ uma importância alta para o crescimento da empresa e apresentam determinados esforços tecnológicos. Nesse caso há o reconhecimento de que o produto global nem sempre atende as necessidades locais, de que há a necessidade de produtos específicos com tecnologia apropriada para o mercado nacional.

Nas empresas nacionais observa-se que aproximadamente um quarto das empresas declararou certa importância à $\mathrm{P} \& \mathrm{D}$ como fator limitante para o desenvolvimento de produtos. Uma parcela maior (39\%) que corresponde a uma importância menor deve-se ao fato de a maioria das empresas nacionais atuarem em nichos de mercado com produtos mais tradicionais com pouca exigência de níveis mais elevados de tecnologia. Tal contexto gera uma demanda menor por produtos mais sofisticados e consequentemente menores esforços e importância à P\&D. 


\subsubsection{Engenharia de processo/produção}

O desenvolvimento da capacidade tecnológica para inovação, ou seja, para gerar e gerir de acordo com Bell e Pavitt (1995) e Figueiredo (2004), passa pela capacidade tecnológica de produção. A capacidade tecnológica de produção é necessária para o uso/operação de tecnologias e de sistemas de produção existentes. Conforme Figueiredo (2009), a acumulação de capacidade de produção gera um importante impacto em seu desempenho técnico, ou seja, no aumento da produtividade, na melhoria de qualidade de processos e produtos, redução de custos, entre outros. Reflete-se em eficiência produtiva e na capacidade da empresa em adaptar as operações às circunstâncias de mercado, ou seja, a competitividade da empresa, em termos de produção.

Essa distinção, em economias de industrialização tardia, como a do Brasil, é de fundamental importância, haja vista a diferença tecnológica que existe entre as empresas de países desenvolvidos e em desenvolvimento. $\mathrm{O}$ avanço em direção à fronteira tecnológica e à diminuição dessas diferenças requer o acúmulo de capacidades tecnológicas em nível de produção e inovação.

A análise do desempenho das competências ou habilidades de produção das empresas pesquisadas apoiou-se nos fatores descritos na Tabela 27. É importante considerar que os graus relacionados pelas empresas referem-se aos nichos de mercado em que atuam.

Tabela 27: Capacidades da produção

\begin{tabular}{|c|c|c|}
\hline Cód. & Capacidades de produção & Descrição \\
\hline $\mathrm{P} 1$ & Flexibilidade do produto & $\begin{array}{l}\text { Habilidade da empresa em lidar com produtos fora do padrão } \\
\text { (customização) }\end{array}$ \\
\hline $\mathrm{P} 2$ & Flexibilidade do processo & $\begin{array}{l}\text { Capacidade de produzir pequenas quantidades rentáveis } \\
\text { (eficiencia em custo) }\end{array}$ \\
\hline $\mathrm{P} 3$ & Flexibilidade de volume & $\begin{array}{l}\text { Habilidade de ajustar a capacidade produtiva à flutuações da } \\
\text { demanda }\end{array}$ \\
\hline $\mathrm{P} 4$ & Baixo custo de produção & $\begin{array}{l}\text { Habilidade em minimizar o custo total de produção através da } \\
\text { eficiência operacional }\end{array}$ \\
\hline P5 & Introdução de melhoria em produtos & Habilidade em introduzir melhorias em produtos \\
\hline P6 & Confiabilidade do produto & $\begin{array}{l}\text { Capacidade para aumentar o tempo de falha ou avaria do } \\
\text { produto }\end{array}$ \\
\hline P7 & Velocidade de entrega & Tempo entre pedido do cliente e entrega \\
\hline P8 & Qualidade do produto & Conformidade às especificações \\
\hline P9 & Confiabilidade de entrega & Entregar no tempo prometido \\
\hline $\mathrm{P} 10$ & Inovação no design/projeto & $\begin{array}{l}\text { Habilidades em fornecer produto com características } \\
\text { operacionais superiores aos dos concorrentes }\end{array}$ \\
\hline
\end{tabular}

Fonte: Elaborado a partir da literatura 
Conforme Tabela 28 e Gráfico 12, observa-se uma determinada homogeneidade nas respostas em relação ao grau de desempenho da produção. Pode-se considerar que para a maior parte dos fatores de produção (70\%), o desempenho é bom para maioria das empresas.

Os melhores resultados (graus de importância 5, 6 e 7) podem ser identificados nos fatores relacionados à confiabilidade, qualidade e flexibilidade do produto, com 78,6\%, 76,2\% e 73,8\% de representatividade da amostra. Ou seja, a grande parcela de empresas possui habilidades competitivas em projetos especiais, competência para produzir conforme as especificações e com maior robustez, conforme mostrado no Gráfico. Por outro lado, em somente $23,8 \%$ das empresas o desempenho para a capacidade de produzir pequenas quantidades com eficiência em custo é considerado como bom. Panorama semelhante é observado em relação à flexibilidade do processo, com pouco mais de um terço das empresas $(35,7 \%)$ apresentando bons desempenhos.

A confiabilidade do produto é o fator que apresenta maior grau de desempenho nas habilidades apresentadas. De fato, as empresas, de maneira geral, têm apresentado importantes esforços voltados para a melhoria de produto. Os investimentos nos últimos cinco anos, conforme visto, aumentaram em $43 \%$ das empresas e têm sido mantidos em outras 33\%. Apesar de estes dispêndios não serem suficientes ou parcialmente suficientes para mais de $75 \%$ das empresas, tais esforços refletem na qualidade dos produtos e aumentando no tempo de falha ou avaria do produto.

Gráfico 12: Desempenho dos fatores de produção

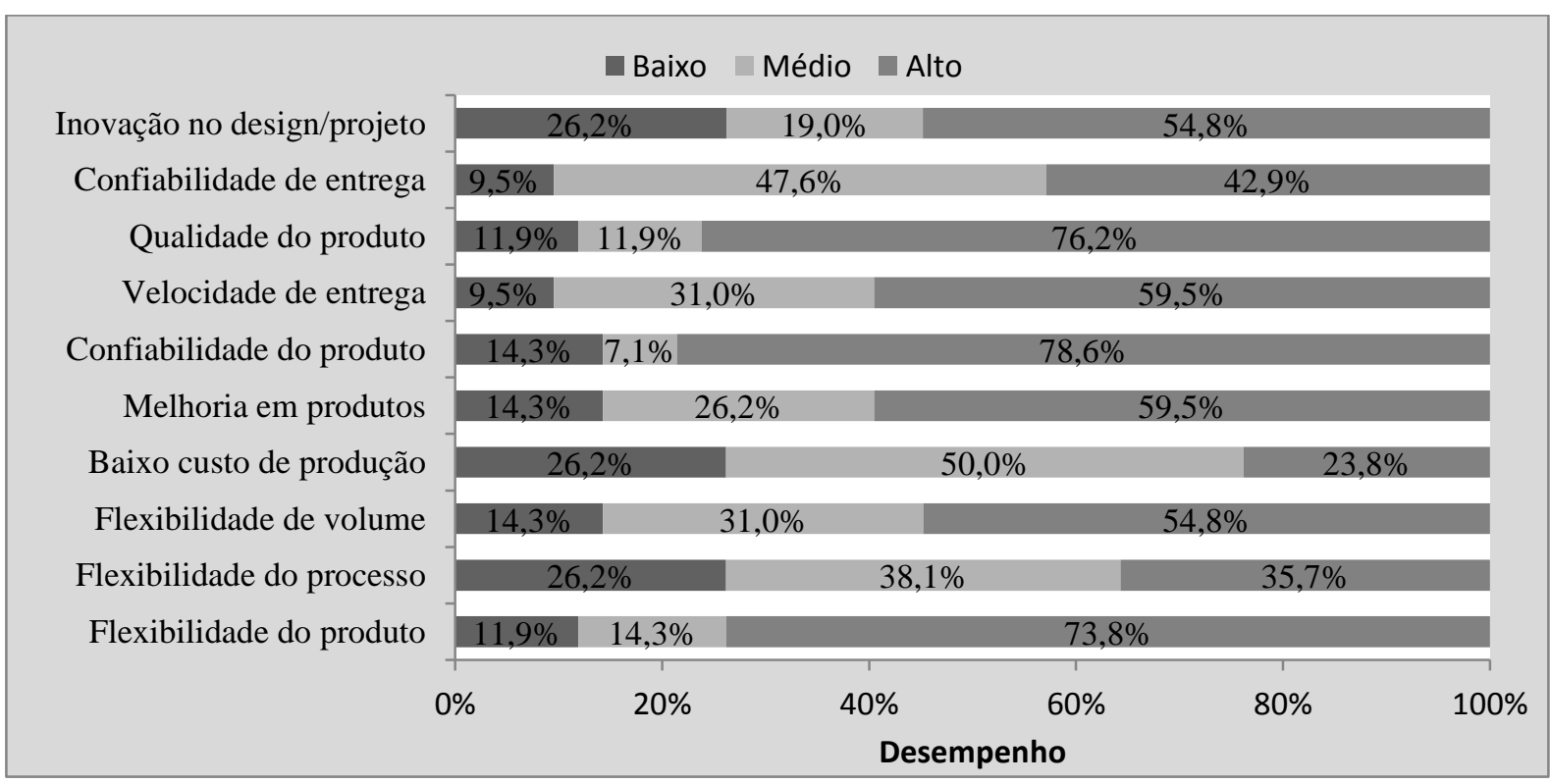

Fonte: Elaborado a partir da literatura 
Mais da metade das empresas $(59,6 \%)$ apresenta boas habilidades em, e em produzir com lead time reduzido. O bom resultado para a velocidade de entrega para essas empresas é alcançado, de certa forma, pelo elevado grau de verticalização da produção que possuem. Por outro lado, $31 \%$ relata uma dificuldade média e aproximadamente $10 \%$ das empresas da amostra apresentam dificuldades maiores nesse fator. Nesses casos encontram-se empresas que destinam partes de sua produção a outras empresas, passando assim a depender da competência e disponibilidade desses fornecedores.

Tabela 28: Desempenho da produção

\begin{tabular}{|c|c|c|c|c|c|c|c|c|c|c|}
\hline \multirow{2}{*}{$\begin{array}{l}\text { Competência/ } \\
\text { Habilidade }\end{array}$} & \multicolumn{7}{|c|}{ Grau de desempenho da produção } & \multirow{2}{*}{ Média } & \multirow{2}{*}{ Moda } & \multirow{2}{*}{$\mathrm{CV}$} \\
\hline & 1 & 2 & 3 & 4 & 5 & 6 & 7 & & & \\
\hline $\mathrm{P} 1$ & $0,0 \%$ & $2,4 \%$ & $9,5 \%$ & $14,3 \%$ & $31,0 \%$ & $38,1 \%$ & $4,8 \%$ & 5,1 & 6 & $22,8 \%$ \\
\hline $\mathrm{P} 2$ & $0,0 \%$ & $0,0 \%$ & $26,2 \%$ & $38,1 \%$ & $23,8 \%$ & $9,5 \%$ & $2,4 \%$ & 4,2 & 4 & $24,3 \%$ \\
\hline P3 & $0,0 \%$ & $0,0 \%$ & $14,3 \%$ & $31,0 \%$ & $38,1 \%$ & $14,3 \%$ & $2,4 \%$ & 4,6 & 5 & $21,5 \%$ \\
\hline $\mathrm{P} 4$ & $0,0 \%$ & $2,4 \%$ & $23,8 \%$ & $50,0 \%$ & $19,0 \%$ & $4,8 \%$ & $0,0 \%$ & 4,0 & 4 & $21,4 \%$ \\
\hline P5 & $0,0 \%$ & $4,8 \%$ & $9,5 \%$ & $26,2 \%$ & $21,4 \%$ & $38,1 \%$ & $0,0 \%$ & 4,8 & 6 & $25,1 \%$ \\
\hline P6 & $0,0 \%$ & $0,0 \%$ & $14,3 \%$ & $7,1 \%$ & $40,5 \%$ & $38,1 \%$ & $0,0 \%$ & 5,3 & 5 & $12,6 \%$ \\
\hline P7 & $0,0 \%$ & $0,0 \%$ & $9,5 \%$ & $31,0 \%$ & $40,5 \%$ & $16,7 \%$ & $2,4 \%$ & 4,7 & 5 & $20,0 \%$ \\
\hline P8 & $0,0 \%$ & $0,0 \%$ & $11,9 \%$ & $11,9 \%$ & $26,2 \%$ & $42,9 \%$ & $7,1 \%$ & 5,2 & 6 & $21,8 \%$ \\
\hline P9 & $0,0 \%$ & $0,0 \%$ & $9,5 \%$ & $47,6 \%$ & $33,3 \%$ & $7,1 \%$ & $2,4 \%$ & 4,5 & 4 & $19,3 \%$ \\
\hline $\mathrm{P} 10$ & $0,0 \%$ & $4,8 \%$ & $21,4 \%$ & $19,0 \%$ & $26,2 \%$ & $28,6 \%$ & $0,0 \%$ & 4,5 & 6 & $27,7 \%$ \\
\hline
\end{tabular}

Fonte: Elaborado a partir de pesquisa de campo

Para muitas empresas, ocorre de não haver fornecedores especializados no Brasil ou fornecedores que atendam aos níveis de qualidade exigidos, ou ainda, fornecedores internos de grande porte, que só fornecem em grandes volumes. Nesses casos, é comum as empresas recorrerem a fornecedores externos, devendo importar esses componentes.

Quanto à capacidade das empresas em entregar o produto no prazo prometido, menos de $10 \%$ da amostra apresentam desempenhos bons em relação à concorrência. Para um terço da amostra $(33,3 \%)$ é desempenho é considerado mediano e para $57,1 \%$

Em relação às capacidades para gerar melhorias ou inovações incrementais no produto, $59,5 \%$ das empresas da amostra possuem boas habilidades. A melhoria de produtos ou inovações incrementais tem sido realizada por todas as empresas nos últimos cinco anos Parcela semelhante é verificada no que se refere às habilidades para gerar inovações no projeto que 
possuam características operacionais superiores aos dos concorrentes $(54,8 \%)$. No entanto, há outra parcela de empresas, que compreende mais de um quarto da amostra $(26,2 \%)$, que apresenta baixos graus de desempenho quanto a essa habilidade. Nessa parcela de empresas, todas são nacionais e dois terços $(66,7 \%)$, de pequeno porte.

Quanto à flexibilidade do volume, nota-se que 54,8\% das empresas possuem habilidades boas para ajustar a capacidade produtiva às flutuações da demanda. Para aproximadamente um terço da amostra (31\%) essa habilidade é mediana. De maneira geral, as empresas não produzem elevados volumes, já que a maioria da produção é sob encomenda. Mesmo que surjam outros projetos, paralelos aos que estão em andamento, vale lembrar, conforme já destacado, que para $84,6 \%$ das empresas existe flexibilidade suficiente no sistema de desenvolvimento de produtos para permitir que outros projetos aconteçam.

Entretanto, é importante destacar que a falta de escala de produção representa uma dificuldade ou obstáculo para o desenvolvimento da empresa. Para aproximadamente $60 \%$ da amostra o fator escala de produção apresenta-se como importante obstáculo, em maior ou menor grau. Tal consideração aplica-se tanto às empresas nacionais como às transnacionais. A baixa escala de produção afeta, em especial, a competitividade das empresas na viabilidade de exportação, pois aumenta o custo médio unitário do produto, e consequentemente os investimentos em pessoal e em tecnologia. De acordo com as empresas, os investimentos voltados para a exportação estão condicionados a uma maior escala de produção. É importante enfatizar que a escala de produção é possível para as empresas que apresentam produtos com grau menor de customização, o que permitiria um volume de vendas em escala. Para as empresas com produtos de grau maior de customização, a escala torna-se difícil, já que atende produtos quase únicos. Nesses casos, a escala de produção não representa um obstáculo maior para o desenvolvimento das empresas.

Além da escala de produção, a produtividade consta como um importante obstáculo para o crescimento das empresas e não apresentam níveis satisfatórios. Para as empresas nacionais as dificuldades são maiores. Para 50\% das empresas os níveis de produtividade estão aquém do desejado e representam um obstáculo significativo. Para as transnacionais, embora em menor quantidade $(35,7 \%)$, os níveis de produtividade também estão abaixo do necessário e impactam no desenvolvimento da empresa.

Dentre os fatores que justificam os níveis insatisfatórios de produtividade estão a qualificação de mão-de-obra, qualidade e as máquinas e equipamentos utilizados pela manufatura. Em especial, para muitas empresas nacionais constatou-se a limitada automatização de processos 
e a utilização de equipamentos convencionais. Vale destacar que há empresas da amostra onde predomina a verticalização da produção, motivada substancialmente pelo controle sobre a tecnologia de processo e de produto. A estratégia de verticalização, apesar dos benefícios de controle mencionados, gera um grande número de atividades realizadas internamente pela empresa, que nem sempre são de domínio, e que por sua vez, originam perda de eficiência e elevação do custo de produção.

No que se refere à flexibilidade do processo, o desempenho é considerado bom somente para $35,7 \%$ das empresas. Para 26,2\% das empresas a capacidade de produzir pequenas quantidades rentáveis, ou seja, com eficiência em custo, é baixa, e para 38,1\%, elevada. Aliado a esse fator, observa-se uma dificuldade em reduzir o custo total de produção através da eficiência operacional. Para metade das empresas o desempenho da produção para a redução do custo de produção é considerado mediano, e baixo para 26,2\%. Em outros termos, menos de um quarto das empresas possuem bom desempenho nesse fator. De uma maneira geral, as empresas apresentam dificuldades importantes no que se refere aos custos de produção.

A eficiência operacional é reconhecida como um elemento crucial para o desempenho da produção, pois contribui diretamente para a disponibilidade, confiabilidade e qualidade dos produtos. Processos de melhoria da produção tais como a gestão da qualidade, Lean Six Sigma, Just In Time, estão presentes, mas em poucas empresas. Outros fatores que contribuem para a baixa eficiência operacional estão relacionados às Máquinas e equipamentos, e qualificação de mão-de-obra. Conforme visto, a necessidade de substituição de máquinas e equipamentos ocorre em $45 \%$ das empresas, e a necessidade de maior qualificação para a área de planejamento e controle da produção (PCP), em 51\%. A necessidade de redução do custo operacional é enfatizada por $67 \%$ das empresas.

Em resumo, vale notar que, em relação ao grau desempenho mais elevado, o total de empresas em cada um dos fatores acima mostrados não supera $10 \%$ do total da amostra. Em outros termos, embora a maioria das empresas apresente um grau satisfatório nos fatores de produção, é inexpressiva (e inexistente em $40 \%$ dos fatores) a parcela de empresas que exibe uma excelência em desempenho em cada fator. Considerando que em muitos casos os mercados são caracterizados por uma acirrada concorrência por preço, esses resultados sugerem a necessidade de melhorias significativas na área produtiva para um desempenho competitivo das empresas. 
Por fim, as empresas, de maneira geral, têm suas atividades direcionadas principalmente para garantir sua sobrevivência apoiada em esforços de melhoria na capacitação produtiva. Esforços voltados para modernização e atualização tecnológica, apesar de apresentarem avanços em determinadas empresas, ainda são modestos. Essa condição, certamente pouco favorece a competitividade dessas empresas, principalmente frente a competidores externos.

\subsubsection{Processos de aprendizagem}

Conforme já apresentado, o modelo que descreve os processos de aprendizagem considera as dimensões do saber tácito e do saber codificado, mas não está limitado às interações dessas duas dimensões. Buscou-se, sobretudo, focar nos processos pelos quais a aprendizagem individual se converte em organizacional, já que a acumulação de saber tácito e de saber codificado, separadamente, não conduz à criação de uma base de conhecimentos na empresa.

A característica principal adotada para os processos de aprendizagem envolve a intensidade em que os mecanismos ocorrem ou estão presentes na organização. Nesses termos, a intensidade em que os processos de aprendizagem ocorrem é caracterizada como rara, intermitente ou esporádica, e contínua.

a) Processos de aquisição externa de conhecimento

Conforme mostrado na Tabela 29, observa-se que em todas as dimensões analisadas há uma parcela significativa de ausência de mecanismos de aprendizagem. A ausência acentuada na aquisição de conhecimento externo corrobora o padrão de comportamento analisado em relação à inovação. As principais fontes de conhecimento e mecanismos para aquisição e conversão recaem fundamentalmente na interação com clientes e fornecedores de tecnologia. Outras fontes para a aprendizagem, tais como pesquisa científica e treinamentos externos ocorrem raramente ou estão ausentes em grande parcela das empresas da amostra.

Entretanto, é importante fazer algumas observações quando analisadas as empresas nacionais e as transnacionais nessa dimensão. O treinamento no exterior é verificado em $85,7 \%$ das empresas transnacionais e ocorre em suas matrizes. Quanto às empresas nacionais, 30,7\% realizam treinamentos no exterior. Observa-se nesse sentido, um esforço importante para a promoção de novos conhecimentos através de mecanismos de aprendizagem externa. No entanto, conforme enfatizado por Figueiredo (2009), tais esforços devem acompanhar paralelamente outros esforços, que são o de gerenciar a conversão do conhecimento adquirido e integrá-los à empresa, na forma de novas rotinas, processos de produção, novos produtos e serviços. 
Tabela 29: Presença e intensidade dos mecanismos de aprendizagem

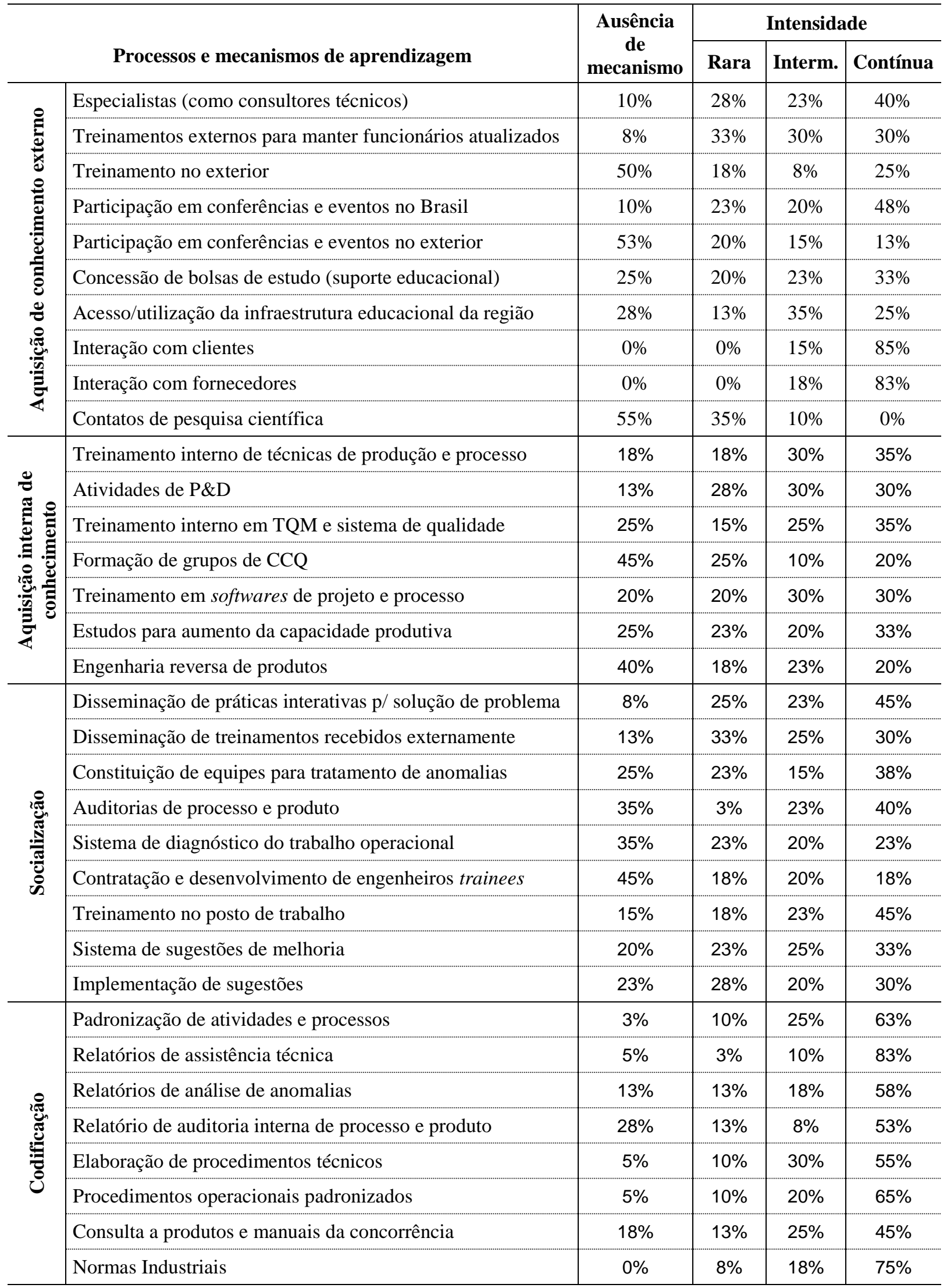

Fonte: Elaborado a partir de pesquisa de campo 
Quanto à participação em conferências e eventos, a presença é verificada em $90 \%$ das empresas, para os realizados no Brasil, e 47\% no exterior. Embora se tenha uma grande presença de empresas para os eventos realizados no Brasil, somente $48 \%$ dos respondentes declararam participar continuamente. Uma barreira exposta pelas empresas é o elevado custo de participação, em especial as feiras internacionais. Para 23\% da amostra, a participação em conferências e eventos no Brasil ocorre raramente. No caso das realizadas no exterior, esse índice de participação contínua é muito inferior, de apenas 13\%, e deste total, $80 \%$ são empresas transnacionais. O objetivo principal da participação, relatado pela maioria dos respondentes, é expor o produto, seguido pelo interesse de atualização. A participação em feiras é fundamental, pois permite a observação de máquinas e equipamentos avançados, tornando-se uma fonte de aprendizado importante, em especial para a imitação e engenharia reversa, conforme destacado por Kim (2005).

A assistência técnica realizada no exterior, pelas empresas exportadoras, constitui também um meio de adquirir conhecimento externo. Em algumas empresas, com escritórios comerciais e de pós-venda na Alemanha e EUA, o estreito contato com equipes locais de assistência técnica tem oferecido conhecimentos importantes e necessários para a realização de mais atividades inovadoras.

A aquisição de conhecimento por meio de especialistas, como consultores técnicos, também é considerada por $90 \%$ das empresas. Para $40 \%$ da amostra, a intensidade com esse mecanismo de aprendizagem é alta, com ocorrências contínuas. Em proporção menor (23\%), a presença é intermitente, e para $28 \%$, rara. De maneira geral, a permanência de especialistas apresenta uma boa adesão.

A infraestrutura educacional da região é pouco explorada. Apesar de as empresas se localizarem em uma região provida de vários centros educacionais, a interação é considerada bastante modesta. A principal fonte citada é o Senai - Serviço Nacional de Aprendizagem Industrial. O Senai é considerado uma grande fonte de aprendizagem, principalmente para as empresas de pequeno porte, as quais são mais bem atendidas quanto às necessidades. Por outro lado, as instituições de ensino não conseguem atender às necessidades de formação técnica demandas por muitas empresas, em especial as transnacionais. Para essas empresas a lacuna de oferta técnica é mais evidenciada. Vale destacar que o setor de bens de capital é muito heterogêneo, e fatores tais como a complexidade das diferentes tecnologias e máquinas que se apresentam, contribuem para a dificuldade no atendimento das demandas específicas. 
Quanto ao suporte educacional, observa-se a presença na maioria das empresas, em maior ou menor intensidade. As concessões de bolsas de estudo ocorrem continuamente para aproximadamente um terço das empresas (33\%), e para $20 \%$ e $23 \%$, a intensidade é rara e média, respectivamente. Muitas empresas não oferecem suporte educacional aos funcionários (28\%), mas apoiam e facilitam a jornada de trabalho para que eles possam frequentar os cursos. No entanto, vale destacar que o suporte educacional, na maioria das vezes, é desvinculado das necessidades de aperfeiçoamento demandadas pelas empresas, tais como pesquisa e maior qualificação nas áreas da engenharia, Em muitos casos, os funcionários fazem as escolhas, sem necessariamente estarem relacionadas às necessidades da empresa. No entanto, as bolsas de estudo, para algumas empresas servem como mecanismo estratégico para acúmulo de conhecimento tácito e codificado, por exemplo, a partir de maior qualificação de engenheiros.

b) Processos de aquisição interna de conhecimento

Os processos de aquisição interna de conhecimento, conforme Figueiredo (2003), referem-se aos processos pelos quais as pessoas adquirem conhecimentos tácitos exercendo diferentes atividades na empresa, por exemplo, cumprindo tarefas rotineiras ou aperfeiçoando os processos e organização da produção, os equipamentos e os produtos existentes. Isso também pode ocorrer em centros de $\mathrm{P} \& \mathrm{D}$ formalmente organizados, em laboratórios da empresa e/ou mediante experimentação sistemática nas diversas unidades operacionais.

Pela Tabela 29, a aquisição de conhecimento interno pode ser caracterizada como heterogênea, sendo intermitente e contínua para 50\% a 60\% das empresas, e ausente e rara para $35 \%$ a $45 \%$ das empresas, aproximadamente. Os treinamentos internos de técnicas de produção e processo, e em sistemas de qualidade, são contínuos para 35\% da amostra em ambos os casos. Nota-se para essas empresas uma atenção maior no aperfeiçoamento da produção, desenvolvimento de produto e qualidade. No entanto, para esses mesmos mecanismos, são verificadas ausências em 18\%, 25\% do total de empresas da amostra, respectivamente, conforme mostrado no Gráfico.

Para Pesquisa e Desenvolvimento, mais de $40 \%$ das empresas não realizam atividades ou realizam raramente. Nesse aspecto, somente $13 \%$ dos respondentes declararam que não realizam atividades de $\mathrm{P} \& \mathrm{D}$; atuam no mercado com o mesmo produto há muito tempo, e afirmam que "não há mais o que se melhorar no produto". As atividades raras se referem àquelas que são realizadas somente quando requeridas por algum projeto específico; não ocorrem sistematicamente em um processo de melhoria contínua. As atividades de P\&D são 
fundamentais, pois permitem às empresas que fiquem atentas ao significado de novos sinais externos e que explorem as informações disponíveis de forma mais eficiente, conforme enfatizado por Kim (2005).

A engenharia reversa também apresenta um comportamento heterogêneo. Para $58 \%$ das empresas, a engenharia reversa está ausente nas empresas ou é rara como mecanismo de aprendizagem. Somente para $20 \%$ a intensidade dessa atividade é contínua e intermitente, para 23\% das empresas, conforme Gráfico 13.

\section{Gráfico 13: Aquisição interna do conhecimento}

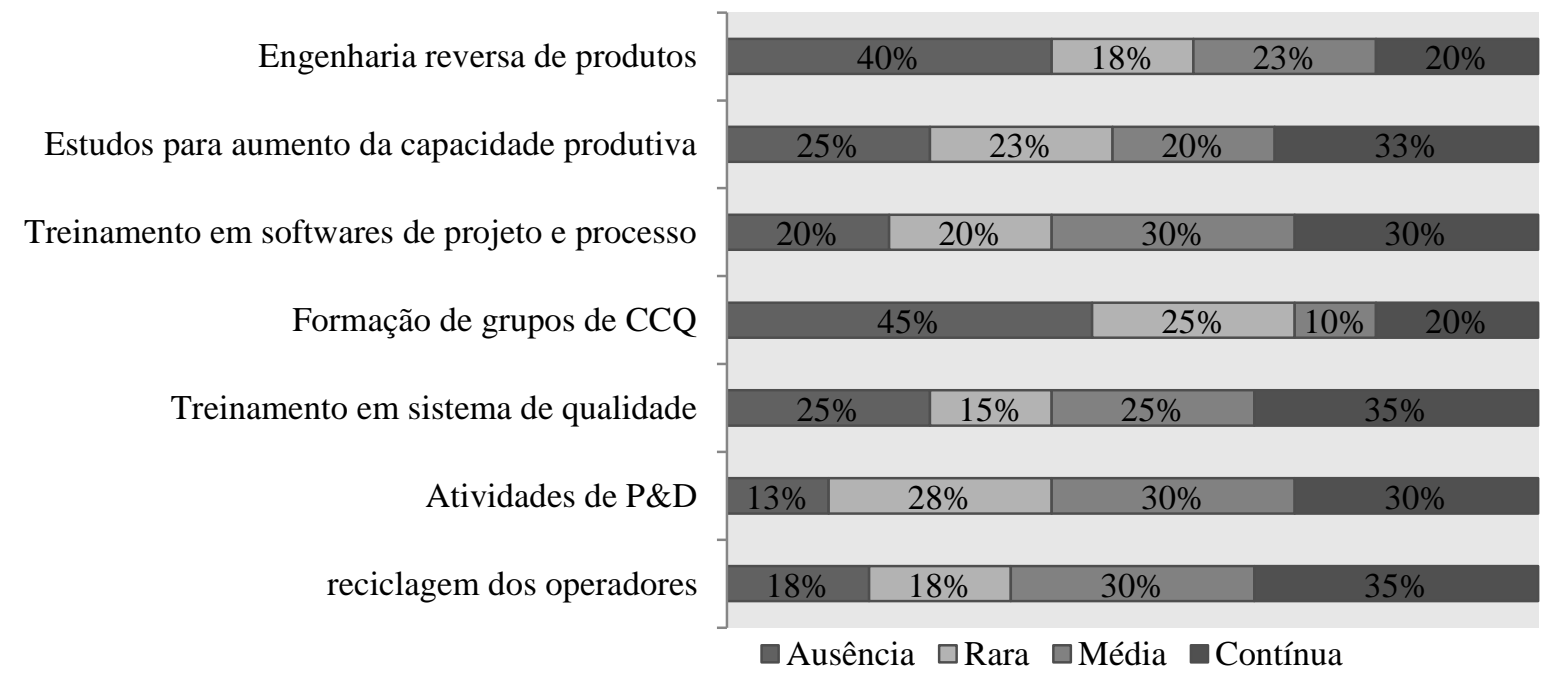

Fonte: Elaborado a partir de pesquisa de campo

Quanto aos aspectos relacionados à qualidade, há uma ênfase maior em treinamento operacional, muito presente em empresas certificadas pela ISO 9000. As empresas que não são certificadas, em sua maioria, não apresentam treinamentos nessa área e nem dispõe de formação de grupos de controle da qualidade para o tratamento de anomalias. Os chamados grupos de CCQ (Círculos de Controle da Qualidade) estão pouco presentes. Mesmo para empresas que são certificadas pela ISO 9000, são poucas as que possuem equipes formalizadas e com atuação específica no tratamento das anomalias e outras questões sobre qualidade. O tratamento de anomalias é realizado, na maioria das vezes, por equipes de profissionais não especializados, com apenas formação básica.

O estudo da capacidade produtiva é realizado de forma contínua por apenas um terço das empresas (33\%) e é ausente como mecanismo de aprendizagem em 25\%, sendo todas empresas de pequeno porte. As empresas que mais desenvolvem estudos da capacidade produtiva são as de médio porte, e 70,6\% são nacionais. 
c) Processos de socialização de conhecimento

Os processos de socialização de conhecimentos referem-se aos processos pelos quais os indivíduos compartilham seu saber tácito (modelos mentais e aptidões técnicas). Envolvem treinamentos, solução conjunta de problemas, rotatividade de tarefas, observação, reuniões, entre outras atividades Pessoas com diferente formação e experiência podem socializar ou disseminar seu conhecimento tácito com estagiários e instrutores.

De maneira geral, para os diversos processos relacionados à disseminação observam-se dois grupos de empresas. Um grupo de empresas com representativa ausência ou intensidade rara dos mecanismos e outro grupo com intensidade média ou contínua. Para o primeiro grupo, há uma grande presença de empresas nacionais e de pequeno porte, enquanto no segundo grupo, empresas de porte maior e transnacionais.

Pela Tabela 29, nota-se que para mais de 50\% das empresas, em vários mecanismos de aprendizado, verifica-se uma média a contínua intensidade quanto à socialização do conhecimento. Os mecanismos que mais se destacam são a disseminação de práticas interativas para solução de problemas, constituição de equipes para o tratamento de anomalias, auditorias de processo e produto, treinamento no posto de trabalho, e sistema de sugestão e implementação de melhorias.

Vale notar, no entanto, que alguns desses mecanismos, apontados acima como positivos, se apresentam com intensidade oposta para uma parcela de empresas. Há uma ausência de mecanismos de aprendizagem, tais como auditorias de processo e produto, e a constituição de equipes para o tratamento de melhorias, para $35 \%$ e $25 \%$ das empresas, respectivamente. O mecanismo que apresenta a maior ausência é o da contratação e desenvolvimento de engenheiros trainees, com $45 \%$ dos casos. Somente $18 \%$ da amostra possuem programas formalizados e adequados para o desenvolvimento de engenheiros trainees nas empresas. Entretanto, vale destacar que no caso de ausência desse mecanismo, $89 \%$ compreendem empresas nacionais, e no de intensidade contínua, ocorre o contrário, 85,7\% das empresas que aderem aos programas são transnacionais.

No que se refere ao sistema de sugestão de melhoria, na maioria das empresas ele não é formalizado, as sugestões ocorrem de maneira informal. Vale destacar também, que muitas empresas não possuem esse mecanismo, mas já tentaram em outros momentos, porém sem sucesso. Os respondentes declararam que o retorno das sugestões é muito positivo, no entanto, decidiram excluir tais programas por não terem encontrado um modelo ideal de recompensa. 
Em muitos casos, a recompensa praticada não satisfaz o funcionário e gera um efeito contrário, de desinteresse e baixa motivação.

d) Processos de codificação de conhecimento

Os processos de codificação de conhecimentos são aqueles pelos quais o saber tácito individual (ou parte dele) é expresso em conceitos explícitos, de forma organizada e acessível, tornando-se mais facilmente assimilável, facilitando assim, a disseminação dos conhecimentos na empresa. Os principais mecanismos envolvem padronização dos métodos, de produção e documentação.

É importante destacar, conforme Figueiredo (2003; 2009), que a organização de módulos de treinamento pelo pessoal interno pode tanto envolver processos de socialização quanto de codificação do saber. Em outros termos, é por meio desses dois tipos de processos que a conversão da aprendizagem individual em aprendizagem organizacional ocorre.

Conforme mostrado na Tabela 29, dentre os processos e mecanismos de aprendizagem, o processo de codificação é o que apresenta a maior intensidade entre os mecanismos avaliados. As práticas para a padronização de atividades e processos se desenvolvem continuamente nas empresas investigadas. Nota-se uma importância dada pelas empresas ao controle das atividades operacionais e do sistema de produção.

As empresas, de maneira geral, organizam bem a própria documentação, e incluem a experiência de seu pessoal nas atividades relacionadas ao aprimoramento de processos e produtos. Vale lembrar que em sua grande maioria os produtos possuem um elevado grau de especialização, e assimilação das lições apreendidas em projetos anteriores são de fundamental importância. Muitos respondentes enfatizaram a importância de se ter uma documentação sistemática, já que é comum entre diferentes projetos desenvolvidos, que a solução para uma determinada aplicação possa servir de base para outra. Como consequência, os relatórios de assistência técnica e os de anomalias, são realizados e organizados continuamente para $83 \%$ das empresas.

Os relatórios de auditoria interna de processo e de produto constam como ausentes em $28 \%$ das empresas, as quais são representadas em $53 \%$ por empresas não certificadas pela ISO 9000. Sugere-se que haja uma relação entre as empresas que realizam auditoria interna continuamente e empresas que possuem a certificação ISO 9000, já que 78,3\% das empresas que possuem certificação realizam auditorias internas de produto e processo. As empresas que são certificadas pela ISO 9000, de certa maneira, são mais estimuladas (pelas próprias 
disposições da norma) a produzirem relatórios de auditoria interna. No entanto, vale destacar que dentre as empresas que não possuem certificação, $47 \%$ realizam auditorias internas de produto e processo com algum grau de intensidade.

Em resumo, pode-se afirmar que embora os tipos de processos estejam presentes, eles diferem em termos de intensidade, com exceção do processo de codificação, no qual se observa uma homogeneidade na intensidade, que predominantemente é de presença intensa. A identificação dessas diferenças de intensidade é fundamental, pois reflete as diferenças no acúmulo de competências tecnológicas adquiridas ao longo do tempo. Em outros termos, a gestão eficaz de vários mecanismos de aprendizagem tecnológica é crucial, pois impacta a maneira e a velocidade pela qual uma empresa acumula suas capacidades tecnológicas ao longo de sua trajetória.

e) Tipos de aprendizagem

As atividades relacionadas à aquisição de conhecimento externo e interno, e à socialização, podem ser relacionadas aos diversos tipos de aprendizagem, conforme apresentado por Malerba (1992). A aprendizagem por interação ou learning by interacting envolve atividades com especialistas, como consultores técnicos, a participação em conferencias e eventos no Brasil e no exterior, o acesso à infraestrutura educacional e as atividades com clientes e fornecedores. A interação com clientes e fornecedores conforme visto é contínua para a grande maioria das empresas.

Tal intensidade estimula as melhorias no processo produtivo e mudanças tecnológicas incrementais, além de desenvolver "curvas de aprendizado". Em relação ao aprendizado por pesquisa ou learning by searching, é pouco presente para a maioria das empresas. No que se refere a contatos de pesquisa científica é inexistente, e de intensidade rara a média em relação às atividades internas de $\mathrm{P} \& \mathrm{D}$. A intensidade contínua ocorre para menos de um terço das empresas.

As atividades de pesquisa externa são cruciais para identificação de novas tecnologias, que quando internalizadas conduzem a acumulação de capacidade tecnológica. As atividades formais internas de $\mathrm{P} \& \mathrm{D}$, por sua vez, são responsáveis pela criação de novos conhecimentos. Nota-se que há poucos esforços para o acúmulo de capacidade tecnológica por meio desse tipo de aprendizagem.

Quanto à aprendizagem por experiência ou learning by doing, têm-se as atividades rotineiras da empresa relacionadas ao processo produtivo, tais como a engenharia reversa de produtos, 
os mecanismos de disseminação de práticas e treinamentos recebidos, e a constituição de equipes para tratamento de anomalias e melhoria de produtos e processos. Com exceção da engenharia reversa, que apresenta intensidade contínua em poucas empresas, uma parcela significativa de empresas possuem práticas de aprendizagem com intensidade média-contínua. Comparativamente, é o tipo de aprendizagem que apresenta maior participação de empresas com intensidade contínua nas práticas. As atividades contínuas desses mecanismos de aprendizagem desenvolvem habilidades crescentes na produção, que reduzem os custos de mão-de-obra por unidade de produto e a incidência de anomalias. São resultados desse aprendizado, produtos com melhor qualidade e inovações incrementais em produto e processo.

\subsubsection{Padrão de comportamento para a inovação}

A Tabela mostra os resultados em relação ao padrão de comportamento que promovem a capacidade de inovar das empresas, bem como as habilidades para organizar e gerenciar o processo.

Foram analisados aspectos em relacionados às dimensões (a) estratégia, que envolve a posição da empresa, no que se refere a seus produtos e tecnologias; (b) processos; que abrange a aprendizagem estratégica além dos limites divisionais e funcionais da empresa; (c) contexto organizacional, que envolve o compartilhamento da identificação de problemas e a capacidade para capturar e acumular aprendizagem sobre tecnologia; e (d) interações, as quais compreendem relacionamentos externos com fornecedores de tecnologias, mercado e outros colaboradores organizacionais, oferecendo oportunidades para aprendizagem com clientes difíceis e usuários importantes.

Para avaliar a confiabilidade ou fidedignidade da escala utilizou-se o coeficiente Alfa de Conbrach, considerado a medida mais amplamente usada. Para pesquisas exploratórias, o limite inferior para o Alfa de Conbrach geralmente aceito á de 0,60 (HAIR JR. et al., 2009). São apresentados também os escores da correlação total dos itens corrigidos, que são as correlações entre cada item e o escore total do constructo. O escore aceitável para que um item tenha uma boa correlação com o total de itens é de 0,30 (FIELD, 2009).

Os resultados do cálculo dos coeficientes e dos escores de correlação dos itens seguem na Tabela. 
De acordo com a Tabela 30, os valores obtidos para o Alfa de Conbrach são todos acima de 0,6, o que indica boa confiabilidade. Os escores da correlação item-total apresentam valores acima de 0,30 , atendendo assim a recomendação.

Vale observar, no entanto, que para as variáveis relacionadas à Interação e ações conjuntas com outras empresas, foi necessário eliminar a variável I2-compreensão boa das necessidades dos clientes. O escore apresentado por essa variável $(0,215)$ está muito abaixo de 0,3 , o que pode indicar uma consistência interna ruim. Optou-se por sua eliminação, pois além de apresentar uma correlação item-total muito baixa, sua exclusão aumentou o valor do índice de confiabilidade de 0,710 (valor obtido com a variável I2 incluída) para 0,737.

Tabela 30: Coeficiente de Alfa de Conbrach e do escore de correlação dos itens

\begin{tabular}{|c|c|c|c|}
\hline Var. & Descrição & $\begin{array}{c}\text { Alfa de } \\
\text { Conbrach }\end{array}$ & $\begin{array}{l}\text { Correlação } \\
\text { Item-total } \\
\text { corrigida }\end{array}$ \\
\hline $\mathbf{E}$ & Estratégia & & \\
\hline E1 & Clareza de como a inovação pode ajudar a empresa & \multirow{5}{*}{0,742} & 0,460 \\
\hline $\mathrm{E} 2$ & Clareza na definição do diferencial competitivo da empresa & & 0,402 \\
\hline E3 & Uso de ferramentas de técnicas de prospecção tecnológica & & 0,389 \\
\hline E4 & Visão compartilhada do desenvolvimento da empresa pela inovação & & 0,717 \\
\hline E5 & Ligação clara entre projetos de inovação e a estratégia geral da empresa & & 0,637 \\
\hline $\mathbf{P}$ & \multicolumn{3}{|l|}{ Processos } \\
\hline $\mathrm{P} 1$ & Processos organizados para a gestão de desenvolvimento de produto & \multirow{5}{*}{0,835} & 0,769 \\
\hline $\mathrm{P} 2$ & Mecanismos eficazes para entendimento das necessidades dos clientes & & 0,806 \\
\hline P3 & Mecanismos adequados para envolvimento de todos os departamentos & & 0,654 \\
\hline P4 & Conclusão dos projetos no prazo e dentro do orçamento & & 0,608 \\
\hline P5 & Flexibilidade no desenvolvimento de produto $\mathrm{p} /$ inserir pequenos projetos & & 0,365 \\
\hline $\mathbf{O}$ & \multicolumn{3}{|l|}{ Organização } \\
\hline $\mathrm{O} 1$ & Trabalham bem em conjunto além dos limites departamentais da empresa & \multirow{5}{*}{0,871} & 0,758 \\
\hline $\mathrm{O} 2$ & Eficiência na comunicação e atividades por toda a organização & & 0,731 \\
\hline $\mathrm{O} 3$ & Trabalho bom em equipe & & 0,716 \\
\hline $\mathrm{O} 4$ & Envolvimento c/ sugestão de ideias para melhoria de produtos e processos & & 0,614 \\
\hline O5 & Estrutura adequada para tomar decisões rapidamente & & 0,740 \\
\hline $\mathbf{I}$ & \multicolumn{3}{|l|}{ Interação e ações conjuntas com outros agentes } \\
\hline I1 & Universidades e outros centros de pesquisa & \multirow{4}{*}{0,737} & 0,386 \\
\hline $\mathrm{I} 3$ & Outras empresas para desenvolvimento de novos produtos e processos & & 0,559 \\
\hline I4 & Trabalho c/ clientes na exploração e desenvolvimento de novos conceitos & & 0,499 \\
\hline I5 & Desenvolvimento de redes de contato externas & & 0,705 \\
\hline $\mathrm{I} 2$ & Compreensão boa das necessidades dos clientes & Eliminada & 0,215 \\
\hline
\end{tabular}


Verificada a confiabilidade das escala, tem-se a seguir a análise do padrão de comportamento das empresas em relação à inovação. Foram utilizados para análise as frequências das dimensões, a média, a moda e o Coeficiente de Variação (CV). Este último pode ser melhor visualizado na Figura.

a) Estratégia

Conforme Tabela 31, em relação à estratégia, há um reconhecimento da importância da inovação como elemento estratégico, pela maioria das empresas. A definição clara do diferencial competitivo diante do mercado supera $70 \%$ em número de empresas.

Tabela 31: Padrão de comportamento das empresas em relação à inovação

\begin{tabular}{|c|c|c|c|c|c|c|c|c|c|c|c|}
\hline \multirow{3}{*}{\multicolumn{2}{|c|}{$\begin{array}{l}\text { Dimensões do } \\
\text { padrão de } \\
\text { comportamento }\end{array}$}} & \multicolumn{7}{|c|}{ Grau de ocorrência } & \multirow{3}{*}{ Média } & \multirow{3}{*}{ Moda } & \multirow{3}{*}{$\mathrm{CV}$} \\
\hline & & \multicolumn{5}{|c|}{ Não Ocorre } & \multicolumn{2}{|c|}{$\begin{array}{r}\text { Ocorre } \\
\text { Plenamente }\end{array}$} & & & \\
\hline & & 1 & 2 & 3 & 4 & 5 & 6 & 7 & & & \\
\hline \multirow{5}{*}{ 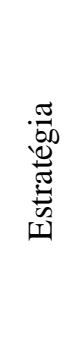 } & E1 & $0,0 \%$ & $28 \%$ & $22,5 \%$ & $27,5 \%$ & $25,0 \%$ & $15,0 \%$ & $10,0 \%$ & 4,63 & 4 & $28 \%$ \\
\hline & E2 & $0,0 \%$ & $21 \%$ & $7,5 \%$ & $20,0 \%$ & $30,0 \%$ & $35,0 \%$ & $7,5 \%$ & 5,15 & 6 & $21 \%$ \\
\hline & E3 & $25,0 \%$ & $60 \%$ & $15,0 \%$ & $10,0 \%$ & $12,5 \%$ & $10,0 \%$ & $2,5 \%$ & 3,00 & 2 & $60 \%$ \\
\hline & $\mathrm{E} 4$ & $0,0 \%$ & $28 \%$ & $20,0 \%$ & $20,0 \%$ & $20,0 \%$ & $30,0 \%$ & $7,5 \%$ & 4,78 & 6 & $28 \%$ \\
\hline & E5 & $0,0 \%$ & $29 \%$ & $27,5 \%$ & $12,5 \%$ & $25,0 \%$ & $22,5 \%$ & $12,5 \%$ & 4,80 & 3 & $29 \%$ \\
\hline \multirow{5}{*}{$\begin{array}{l}0 \\
0 \\
0 \\
0 \\
0 \\
0 \\
0 \\
0\end{array}$} & $\mathrm{P} 1$ & $0,0 \%$ & $25 \%$ & $12,5 \%$ & $17,5 \%$ & $32,5 \%$ & $27,5 \%$ & $7,5 \%$ & 4,93 & 5 & $25 \%$ \\
\hline & $\mathrm{P} 2$ & $0,0 \%$ & $34 \%$ & $42,5 \%$ & $17,5 \%$ & $12,5 \%$ & $17,5 \%$ & $5,0 \%$ & 4,10 & 3 & $34 \%$ \\
\hline & P3 & $0,0 \%$ & $31 \%$ & $37,5 \%$ & $15,0 \%$ & $25,0 \%$ & $15,0 \%$ & $5,0 \%$ & 4,28 & 3 & $31 \%$ \\
\hline & $\mathrm{P} 4$ & $0,0 \%$ & $28 \%$ & $27,5 \%$ & $30,0 \%$ & $27,5 \%$ & $7,5 \%$ & $2,5 \%$ & 4,13 & 4 & $28 \%$ \\
\hline & P5 & $0,0 \%$ & $21 \%$ & $7,7 \%$ & $7,7 \%$ & $43,6 \%$ & $23,1 \%$ & $17,9 \%$ & 5,36 & 5 & $21 \%$ \\
\hline \multirow{5}{*}{ 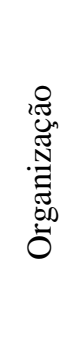 } & $\mathrm{O} 1$ & $0,0 \%$ & $21 \%$ & $7,5 \%$ & $30,0 \%$ & $35,0 \%$ & $22,5 \%$ & $5,0 \%$ & 4,88 & 5 & $21 \%$ \\
\hline & $\mathrm{O} 2$ & $0,0 \%$ & $24 \%$ & $15,0 \%$ & $47,5 \%$ & $17,5 \%$ & $15,0 \%$ & $5,0 \%$ & 4,48 & 4 & $24 \%$ \\
\hline & O3 & $0,0 \%$ & $21 \%$ & $10,0 \%$ & $30,0 \%$ & $30,0 \%$ & $27,5 \%$ & $2,5 \%$ & 4,83 & 5 & $21 \%$ \\
\hline & $\mathrm{O} 4$ & $2,5 \%$ & $35 \%$ & $32,5 \%$ & $17,5 \%$ & $17,5 \%$ & $20,0 \%$ & $5,0 \%$ & 4,23 & 3 & $35 \%$ \\
\hline & O5 & $0,0 \%$ & $24 \%$ & $5,0 \%$ & $20,0 \%$ & $27,5 \%$ & $30,0 \%$ & $15,0 \%$ & 5,23 & 6 & $24 \%$ \\
\hline \multirow{4}{*}{ 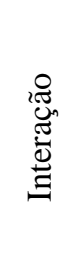 } & I1 & $42,5 \%$ & $61 \%$ & $12,5 \%$ & $12,5 \%$ & $2,5 \%$ & $2,5 \%$ & $0,0 \%$ & 4,88 & 1 & $61 \%$ \\
\hline & I3 & $22,5 \%$ & $57 \%$ & $12,5 \%$ & $15,0 \%$ & $7,5 \%$ & $22,5 \%$ & $2,5 \%$ & 4,48 & 6 & $57 \%$ \\
\hline & I4 & $12,5 \%$ & $46 \%$ & $15,0 \%$ & $12,5 \%$ & $22,5 \%$ & $20,0 \%$ & $5,0 \%$ & 4,83 & 5 & $46 \%$ \\
\hline & I5 & $22,5 \%$ & $57 \%$ & $27,5 \%$ & $7,5 \%$ & $10,0 \%$ & $12,5 \%$ & $2,5 \%$ & 4,23 & 3 & $57 \%$ \\
\hline
\end{tabular}

Fonte: Dados processados a partir de pesquisa de campo 
Da mesma forma, para a maioria das empresas, os principais executivos têm uma visão compartilhada do desenvolvimento da organização por meio da inovação. Segue o mesmo comportamento a ligação clara entre os projetos de inovação e a estratégia geral do negócio.

No entanto, em relação ao uso de ferramentas e técnicas de prospecção tecnológica nota-se uma variação significativa na ocorrência entre os respondentes. Constatou-se que $25 \%$ das empresas não faz uso de nenhum tipo de ferramenta para esta finalidade, em muitos casos por desconhecimento das ferramentas, e $40 \%$ fazem uso muito limitado. Por outro lado, há $25 \%$ de empresas que possuem sistemas formalizados, que procuram prever o comportamento do mercado e da tecnologia para poderem se antecipar às tendências do mercado por meio de estratégias adequadas. Somente 2,5\% apresentam uso pleno das ferramentas. Vale destacar que dentre as empresas que melhor apresentam ferramentas de prospecção tecnológica $70 \%$ são transnacionais e 30\% nacionais. No caso das transnacionais, as atividades são geralmente compartilhadas com as respectivas matrizes. Por outro lado, dentre as empresas que não fazem uso ou desconhecem as ferramentas, $90 \%$ são empresas nacionais. Essas diferenças de comportamento podem ser verificadas pelo elevado coeficiente de variação apresentado, que é de $60 \%$. O Gráfico 14 mostra os coeficientes variação da dimensão.

Gráfico 14: Coeficientes de variação: padrão de comportamento para a inovação

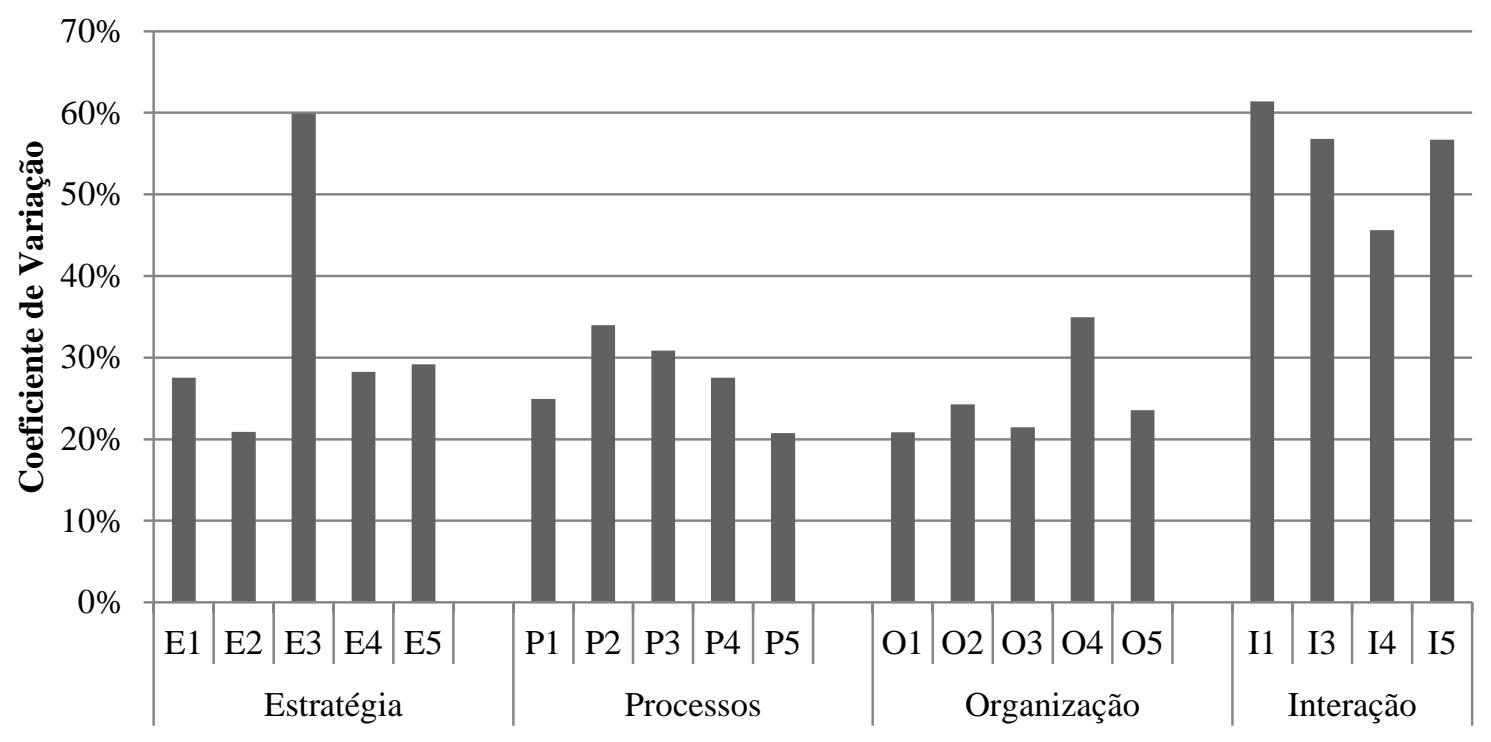

Fonte: Elaborado a partir de pesquisa de campo

b) Processos

Quanto aos processos, a flexibilidade no desenvolvimento de produto é a principal característica apresentada pela maioria das empresas $(84,6 \%)$. Tal habilidade era esperada, já que em sua maioria, os projetos são específicos, e um constante desenvolvimento de soluções 
variadas ocorre, o que facilita a inserção de pequenos projetos em paralelo com outros já em andamento. Outro aspecto positivo refere-se à organização dos processos. Para 67,5\% das empresas, os processos para a gestão de desenvolvimento de produto desde a ideia até o lançamento, são organizados e apropriados em bom nível.

Os resultados que apresentam os menores graus de adesão referem-se ao envolvimento das diferentes áreas da organização no processo de desenvolvimento do produto. Uma parcela significativa da amostra $(47,5 \%)$ não possui mecanismos eficazes para garantir que todos os funcionários entendam as necessidades dos clientes. De maneira geral esse entendimento ocorre somente por parte do pessoal da engenharia, em especial, dos projetistas. Há pouco envolvimento prévio de todos os departamentos no desenvolvimento de novos produtos ou processos. Em somente 5\% da amostra esses mecanismos estão presentes plenamente nas empresas.

No que se refere à conclusão dos projetos de desenvolvimento de novos produtos dentro dos prazos e orçamentos, pode-se considerar seu cumprimento como regular $(4,13)$. Somente 2,5\% das empresas declararam que a conclusão dos projetos de novos produtos ocorre plenamente no prazo e dentro do orçamento. Todavia, vale destacar que tais prazos e orçamentos não variam muito em relação aos términos estabelecidos.

\section{c) Organização}

No que tange ao contexto organizacional, o padrão de comportamento das empresas pode ser considerado o melhor em relação às demais dimensões. Os resultados mostram uma homogeneidade significativa no comportamento. De maneira geral, as empresas apresentam um bom ambiente para trabalho em equipe e além dos limites departamentais. A comunicação através da organização é considerada regular, mas com algum percentual também muito bom. O ambiente nas empresas, de maneira geral, pode ser caracterizado por uma estrutura pouco rígida, o que favorece a criatividade das pessoas e o aprendizado individual e organizacional. Essas características de comportamento, satisfatórias em sua maioria, são de fundamental importância, em especial, para uma melhor integração dos departamentos da empresa nos processos de desenvolvimento de produto, os quais, conforme mostrado, precisam ser mais presentes. Conforme Kim (2005), a estrutura organizacional, em especial no que se refere ao ambiente organizacional, quando adequado favorece o aprendizado efetivo de seus membros e sua conversão em capacidade organizacional. 
d) Interação e ações conjuntas

A interação e as ações conjuntas com outros agentes apresenta uma grande heterogeneidade, refletida nos coeficientes de variação. Observa-se que a interação com universidades e outros centros de pesquisa não ocorre em $42,5 \%$ das empresas. A ausência de projetos de pesquisa em conjunto com universidades e institutos de pesquisa desproveem as empresas de fontes novas de informações científicas e técnicas, as quais, conforme Kim (2005), são fundamentais porque podem aumentar significativamente a capacidade tecnológica da empresa.

É importante enfatizar que essa característica é comum as empresas nacionais e transnacionais. As relações ocorrem de maneira esporádica e servem de apoio para pontos específicos dos projetos.

No entanto, vale destacar que as empresas, em especial as nacionais, têm interesse em explorar a universidade como fonte de informação e conhecimento, mas encontram dificuldade no acesso e na convergência dos interesses. Quanto às empresas transnacionais, a universidade em muitos casos não consegue atender às suas necessidades. Há também relatos de divergências em relação à propriedade intelectual.

As ações conjuntas para o desenvolvimento de novos produtos e processos ocorrem especialmente com fornecedores e clientes, no entanto para uma pequena parcela de empresas. Na maioria dos casos, junto a fornecedores ocorre uma contratação de um serviço, não há atividades em conjunto no desenvolvimento. Com concorrentes e outras empresas do setor ocorrem interações fundamentalmente para informações, raramente são desenvolvidas ações em projetos. Vale observar que há uma parcela considerável de empresas $(22,5 \%)$ que declararam que não interagem com nenhuma empresa no processo de desenvolvemos de novos produtos ou processos. De acordo com alguns respondentes, não há necessidade de cooperar com outras empresas para o desenvolvimento de seus produtos. Em outros casos, há empresas que necessitam de ações conjuntas, mas encontram barreiras culturais e jurídicas. Há muita resistência em liberar base de informações aos potenciais parceiros, e as empresas não encontram apoio jurídico para sustentar acordos e se protegerem de eventuais divergências.

Em relação ao desenvolvimento de redes de contato externas, essa atividade é ausente para $22,5 \%$ das empresas, e quando ocorre é em níveis discretos de intensidade. Somente $2,5 \%$ da amostra mantêm e desenvolvem, regularmente, redes de contato externas. As empresas 
declararam que devido ao elevado grau de especificidade dos produtos, há uma dificuldade em encontrar pessoas com conhecimento especializado que possam ajudar em determinada necessidade. No caso de transnacionais, esses contatos e apoios geralmente são obtidos junto às matrizes.

Em resumo, pode-se notar que, de maneira geral, o desenvolvimento de novos produtos ocorre fundamentalmente na própria empresa, com poucas parcerias. As relações de interação e cooperação com outros atores são ainda muito fracas, seja por um discreto entendimento da inovação como sendo um fenômeno sistêmico, interativo e com múltiplas origens, seja por falta de cultura empresarial ou por barreiras jurídicas.

\subsection{Fatores externos}

Conforme destacado por Ferraz et al. (1997), as empresas são partes integrantes de um sistema econômico que favorece ou restringe a realização de se potencial competitivo, de modo que a capacidade tecnológica acumulada e o desempenho alcançado não dependam exclusivamente das condutas adotadas pelas empresas. Portanto, o acúmulo da capacidade tecnológica deve levar em conta não apenas os processos internos à empresa, mas também as condições econômicas gerais do ambiente produtivo.

Além dos determinantes econômicos, o sistema setorial de inovação é outra condicionante externa que recai sobre a capacidade tecnológica das empresas. Conforme Cimoli et al. (2006), os processos de geração de novos conhecimentos científicos e tecnológicos envolvem uma variedade de atores, instituições e políticas, complementares voltados para o aprendizado tecnológico, tais como instituições públicas de pesquisa, instituições públicas de treinamento, sociedades técnicas, entre outros.

\subsubsection{Fatores macroeconômicos}

Os fatores macroeconômicos são os que apresentam os maiores graus de concordância em relação aos obstáculos para o desenvolvimento das empresas. Os fatores relacionados ao setor externo (política cambial e política comercial) representam para mais de dois terços da amostra $(67,5 \%)$, em ambos os fatores, uma importante barreira, conforme mostrado na Tabela 32.

O nível de taxa de câmbio real exerce importante papel na determinação da rentabilidade do setor exportador. Para os setores da indústria, a moeda nacional está sobrevalorizada e esta 
sobrevalorização apresenta por um lado, um efeito positivo de incentivo a importação, e por outro lado, um efeito contrário, de desincentivo à exportação.

Tabela 32: Obstáculos externos ao desenvolvimento das empresas

\begin{tabular}{|c|c|c|c|c|c|c|c|c|}
\hline \multirow{2}{*}{$\begin{array}{c}\text { Fatores/ } \\
\text { Obstáculos } \\
\text { externos ao } \\
\text { desenvolvimento }\end{array}$} & \multicolumn{7}{|c|}{ Grau de concordância } & \multirow{2}{*}{ CV } \\
\hline & 1 & 2 & 3 & 4 & 5 & 6 & 7 & \\
\hline Taxa de Juros & $2,5 \%$ & $17,5 \%$ & $15,0 \%$ & $10,0 \%$ & $25,0 \%$ & $12,5 \%$ & $17,5 \%$ & $40,70 \%$ \\
\hline Política Cambial & $2,5 \%$ & $15,0 \%$ & $7,5 \%$ & $7,5 \%$ & $17,5 \%$ & $25,0 \%$ & $25,0 \%$ & $37,39 \%$ \\
\hline $\begin{array}{l}\text { Impostos e } \\
\text { Encargos }\end{array}$ & $2,5 \%$ & $0,0 \%$ & $0,0 \%$ & $2,5 \%$ & $15,0 \%$ & $37,5 \%$ & $42,5 \%$ & $18,86 \%$ \\
\hline Custos Logísticos & $5,0 \%$ & $15,0 \%$ & $25,0 \%$ & $30,0 \%$ & $7,5 \%$ & $7,5 \%$ & $10,0 \%$ & $42,23 \%$ \\
\hline
\end{tabular}

Fonte: Elaborado a partir de pesquisa de campo

Conforme o Gráfico 15, entre janeiro de 2003 e julho de 2013 nota-se um forte aumento do consumo, favorecido pela valorização do Real frente ao dólar e pelo aumento real da renda. No entanto, tais aumentos não se traduziram em aumento da produção, e sim em um aumento de produtos importados, estimulados pela redução do preço em Reais dos mesmos. Um regime cambial que evite uma sobrevalorização crônica do câmbio, conforme enfatizado por Ferraz et al. (1997), é necessário para a preservação da indústria local frente à concorrência.

Gráfico 15: Produção da indústria de transformação, comércio varejista ampliado e paridade cambial

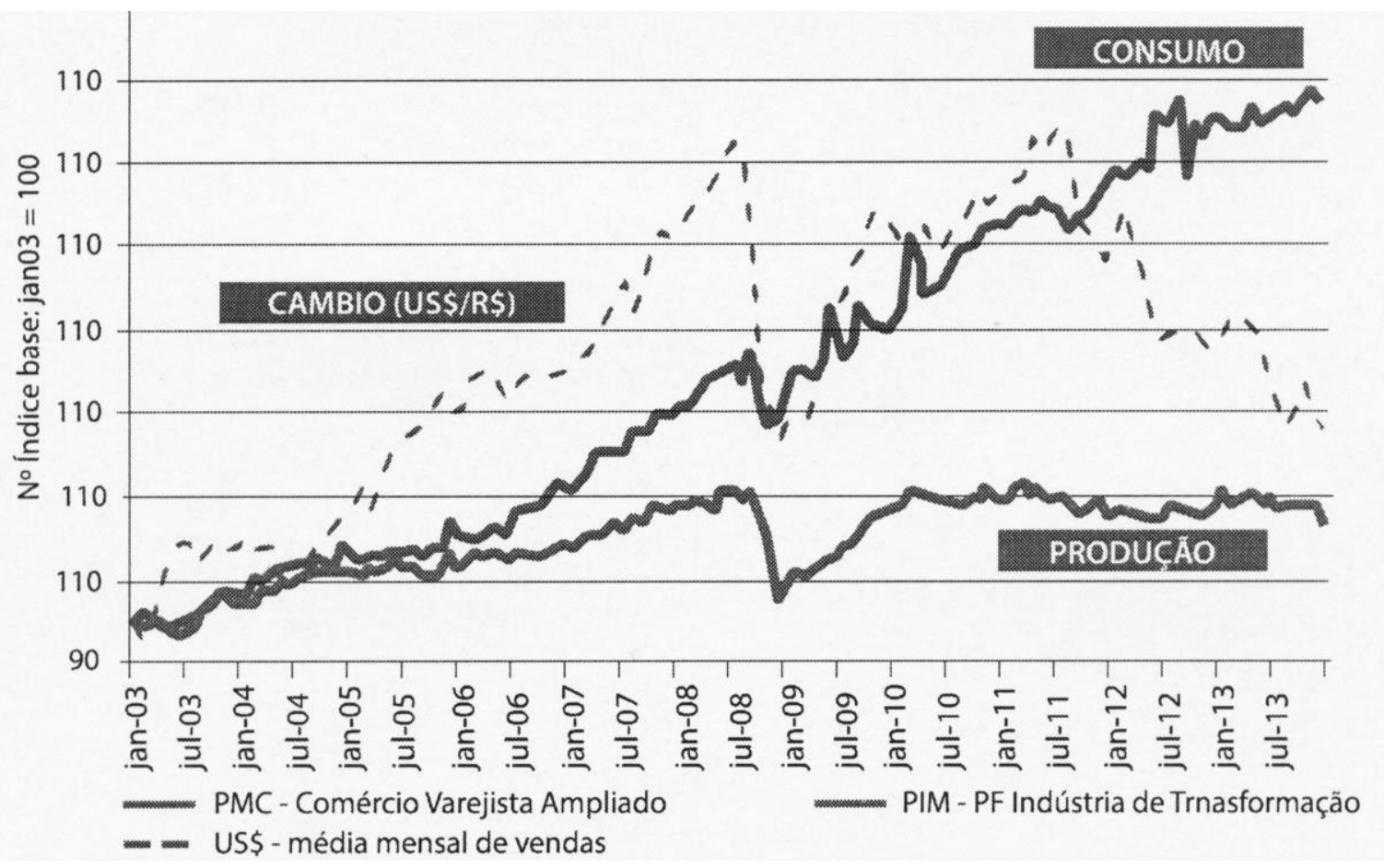

Fonte: DCEE/Abimaq 
As empresas, em especial as nacionais, a fim de amenizar os efeitos negativos da moeda sobrevalorizada buscam, quando possível, recorrer a fornecedores estrangeiros, substituindo os locais. Todavia, a substituição nesses termos gera, em muitos casos, a necessidade de desenvolvimento de fornecedores externos, o que nem sempre é fácil e viável, pois há componentes muito específicos e em quantidades muito reduzidas. No caso das empresas transnacionais, o efeito é menor, já que a maioria delas utiliza uma parcela significativa de componentes importados.

Em relação à taxa de juros, para 55\% das empresas da amostra, os índices praticados pelo mercado são considerados elevados e representam um obstáculo para os investimentos e crescimento das empresas. É importante destacar que a taxa de juros elevada afeta não apenas as empresas fabricantes de máquinas e equipamentos, mas também seus clientes. Os bens de capital são adquiridos fundamentalmente por meio de empréstimos, e portanto, níveis elevados de taxa de juros inibem os investimentos dos setores usuários.

Mas, para 35\% das empresas, a taxa de juros representa um obstáculo menor. Em especial, as empresas transnacionais, em muitos casos, recorrem a instituições financeiras que fazem parte do grupo corporativo e que disponibilizam empréstimos a um custo monetário inferior ao oferecido pelo mercado financeiro local. Mas, vale destacar que as empresas que encontram dificuldade em obter financiamentos em função de uma taxa de juros elevada, são tanto nacionais como transnacionais.

Os impostos e encargos compõem outra parcela de obstáculos ao crescimento das empresas. Para quase totalidade das empresas, a elevada carga de tributos e de impostos, segundo os respondentes, elevam consideravelmente os custos de produção; e como as margens de contribuição do produto (em muitos casos) são pequenas, a competitividade no mercado externo torna-se muito difícil. Além de aumentar os custos de produção os valores de encargos trabalhistas praticados no Brasil inibem a contratação de mais funcionários e com melhor qualificação. Vale lembrar que os níveis de produtividade e a qualidade dos produtos dependem do nível de qualificação da mão-de-obra. Do mesmo modo, a presença de um corpo técnico de alto nível de qualificação é crucial para a geração e incorporação de inovações mais sofisticadas.

O efeito desses fatores afeta tanto a competitividade no mercado externo quanto no mercado interno, em especial no que se refere a produtos importados. Os elevados custos de produção, decorrentes dos tributos e encargos, geram um preço final pouco competitivo, principalmente para as empresas nacionais de pequeno porte, que competem com produtos tradicionais onde 
o padrão de concorrência se dá por preço. Os produtos nacionais, mesmo com os instrumentos de proteção local, têm sua competitividade comprometida na concorrência com os produtos estrangeiros de tecnologia simples, em especial aqueles provindos da China.

Quanto aos custos logísticos, de maneira geral, não representam um obstáculo maior para o desenvolvimento das empresas pesquisadas. As empresas possuem atividades que se concentram fundamentalmente no mercado interno, e para a maioria delas não são gerados grandes estoques, e os custos armazenagem, de transporte ou frete, não são considerados importantes obstáculos para $75 \%$ das empresas, conforme Tabela. Entretanto, para essas mesmas empresas, ao considerarem as exportações, declaram que os custos logísticos passam a ser considerados como um obstáculo maior. Em especial, os custos portuários, de transbordo, de armazenagem em terminais e portos são elevados, e quando somados aos custos de transporte ou frete, tornam o preço final para comercialização pouco competitivo. Além dos custos, a infraestrutura logística no Brasil afeta os prazos de entrega dos produtos exportados. Ocorre muita lentidão, em especial, nos processos administrativos portuários. A baixa eficiência desses processos afeta o nível de serviço, que é um importante componente da competitividade, para as empresas exportadoras. Os obstáculos maiores concentram-se nas exportações direcionados aos mercados da Europa e EUA.

\subsubsection{Sistema setorial de inovação}

Quanto ao sistema setorial de inovação, é importante destacar, inicialmente, as características do ambiente tecnológico ao qual se insere a indústria de bens de capital brasileira, ou seja, seu regime tecnológico. As características do ambiente tecnológico definem as estratégias adotadas pelas empresas, as quais estão diretamente atreladas às condições macroeconômicas. Tais condições determinam a demanda por novas tecnologias e os estímulos por investimentos em novos recursos e mecanismos de aprendizagem para atendê-las.

Entretanto, vale lembrar que na última década apesar do crescimento da demanda por máquinas e equipamentos no Brasil, os investimentos realizados pelas empresas pouco contribuíram para o aprendizado tecnológico dos fabricantes nacionais. Embora as empresas no Brasil detenham importantes competências para atender ao mercado interno, a demanda por tecnologias mais complexas é fundamentalmente atendida por empresas estrangeiras, seja pelas facilidades de aquisição no mercado externo, seja pelo alto custo de produção interna. Nesse sentido, pode-se afirmar que o regime tecnológico estabelece limitações no que se refere à mudança técnica do setor no país. 
As interações entre as empresas e entre empresas e outras instituições representam um importante mecanismo de aprendizagem e atualização tecnológica. Considerando as empresas pesquisadas, de maneira geral, elas se limitam a troca de informações. As ações conjuntas para o desenvolvimento de novos produtos ocorrem com pouca frequência e apresentam algumas dificuldades, conforme já destacado.

Apesar de as empresas localizarem-se no estado de São Paulo, onde estão instaladas várias instituições de ensino e pesquisa há pouca interação entre eles. Vale destacar que os fatores que inibem as ações conjuntas não estão relacionados a condicionantes financeiros. Os respondentes afirmam que há uma carência de instituições educacionais voltadas para o setor de bens de capital. A complexidade e heterogeneidade do setor gera uma dificuldade quanto à disponibilidade de técnicos e cientistas que atendam às necessidades das empresas. Por outro lado, há uma parcela de empresas que oferece produtos de conteúdo tecnológico mais simples e a baixa exigência de conhecimentos em áreas da ciência, considerados mais complexos, não justificaria uma interação ou ação conjunta.

No entanto, é importante frisar que a interação entre instituições de ensino e pesquisa e empresas é de fundamental importância, em especial para as empresas que produzem produtos de tecnologia simples e que, a partir da incorporação de novas tecnologias, mais complexas, possam ampliar seus mercados e competir melhor.

Quanto aos programas de fomento para projetos de desenvolvimento tecnológico, menos de um quarto das empresas $(21,4 \%)$ foi contemplado com algum deles. Do restante, $42,9 \%$ desconhecem os mecanismos de suporte financeiro do Governo ou não ouviram falar dos programas, e 35,7\% conhecem alguns, mas nunca fizeram uso.

Dentre os programas utilizados citados estão a Lei do Bem, com maior número de casos, Finep Inova Brasil, Proengenharia, e financiamentos para aquisição de novos equipamentos. As empresas buscam por meio destes programas, alguns em andamento nas organizações, fundamentalmente o desenvolvimento e aperfeiçoamento de produtos e processos. As empresas que foram contempladas com algum programa de fomento à inovação reconhecem os benefícios gerados e afirmam que sem o acesso os projetos não teriam realizados. Vale destacar, por outro lado, a generalização do conhecimento e do recurso aos financiamentos da Agencia Especial de Financiamento Industrial - Finame, e do Banco Nacional de Desenvolvimento Econômico e Social - BNDES. 
Dentre as dificuldades ou obstáculos ao acesso aos programas apresentados pelas empresas estão a dificuldade de enquadramento nas exigências dos programas. Há empresas que declararam que determinados editais são "fechados", ou seja, referem-se a tecnologias específicas, que muitas vezes não se aderem às necessidades das empresas. As empresas teriam de se adequar às exigências dos editais e não o contrário, ou seja, os editais em consonância com as necessidades das empresas. Houve um caso em que a empresa, ao ter seu projeto avaliado em um dos programas, seu produto foi considerado pouco sofisticado, não caracterizando o projeto como de inovação. Outro obstáculo apresentado refere-se ao prazo de avaliação e ao montante disponibilizado. Para algumas empresas, o tempo entre a apresentação da proposta e a liberação do recurso é muito elevado e em determinados casos o tempo de resposta ao mercado precisa ser menor. Em outros casos, o valor mínimo para acesso aos recursos é muito elevado para a necessidade das empresas.

Algumas empresas afirmaram que estão buscando acesso em algum programa, mas encontram como principal dificuldade a obtenção de informações de como participar, em saber de que forma os programas podem atendê-los e vice-versa. Vale lembrar que essas linhas de fomento são relativamente recentes e as empresas não estão familiarizadas com o modelo de projeto a ser desenvolvido, e não possuem pessoal especializado para elaboração desses projetos nos termos em que são demandados.

A falta de informação sobre os programas e de seus benefícios ocorre em grande parcela das empresas pesquisadas. O Programa BNDES PSI - Inovação e Máquinas e Equipamentos eficientes, que é um programa que atende diretamente o setor de bens de capital, é conhecido por menos de um quarto das empresas pesquisadas.

Há casos de empresas, em especial as transnacionais, que conhecem os programas e reconhecem que atenderiam às necessidades, mas não fazem uso dos mesmos porque as taxas de juros praticadas são consideradas elevadas. Nesses casos, a empresa prefere recorrer a instituições financeiras pertencentes ao grupo corporativo que, de maneira geral, disponibilizam os recursos a um custo de moeda menor.

Outro aspecto importante, que inibe o acesso aos programas, destacado por algumas empresas, refere-se aos riscos econômicos e de mercado. A incerteza da demanda e de que o resultado de uma inovação garanta mais competitividade para a empresa, e o impacto de um fator macroeconômico, como o câmbio desfavorável, inibem os gastos com inovação. 
No entanto, é importante destacar que apesar de os programas apresentarem limitações técnicas e de acesso, podem ser vistos como um avanço em termos de políticas brasileiras para a inovação tecnológica.

De acordo com Luna et al. (2008), no que concerne à disponibilidade de recursos financeiros para a inovação, vale lembrar que os empréstimos bancários tradicionais do setor privado são em sua maioria, de curto prazo, e, portanto, inadequados para a implementação de atividades cujo retorno é de longo prazo e incerto.

O financiamento de longo prazo em países em desenvolvimento, como o Brasil, é de suma importância para o desempenho econômico das empresas. A disponibilidade nesses termos melhora os índices de produtividade, de investimentos e de crescimento das empresas.

\subsubsection{Síntese dos determinantes internos e externos da capacidade tecnológica}

A partir das constatações e das características apresentadas acima, uma síntese das principais características dos determinantes internos e externos da capacidade tecnológica, é mostrada na Quadro 14.

Os casos que representam a amostra apontam para aspectos positivos, que apoiam e estimulam os processos de acúmulo de capacidade tecnológica, mas também para aspectos negativos, que servem de obstáculos ou inibidores.

Observa-se também certa heterogeneidade nas condições das empresas respondentes. Embora as empresas façam parte de um mesmo setor, os inúmeros e diversificados nichos de mercado nos quais atuam, bem como a complexidade e especificidade mostrada nos produtos, geram diferentes condições e necessidades. Mas, há características que são comuns à maioria das empresas, independentemente das condições, dos produtos ou dos nichos de mercado em que atuam.

No que se refere aos recursos humanos, o grau de qualificação da mão-de-obra se mostra suficiente para as atividades atuais de operação na produção, mas para as atividades de inovação, a qualificação atual não atende às exigências, que demandam maior conhecimento científico e tecnológico. Observa-se a presença de poucos engenheiros nas atividades de fabricação, PCP, qualidade e desenvolvimento de produtos. Como resultado, essas características criam barreiras para o acúmulo de capacidade de inovação, que conforme Dahlman et al. (1987), é necessária para gerar ou adaptar novas tecnologias, desenvolver novos produtos e serviços que atendam melhor as necessidades específicas. 
Quadro 14: Sistematização das características apresentadas pelos determinantes internos e externos da capacidade tecnológica nas empresas pesquisadas

\begin{tabular}{|c|c|c|}
\hline \multicolumn{2}{|c|}{ Determinantes } & Características \\
\hline \multirow{4}{*}{ 足 } & $\begin{array}{c}\text { Recursos } \\
\text { Financeiros/ } \\
\text { Investimentos }\end{array}$ & $\begin{array}{l}\text { - } \text { Capital de giro é um obstáculo representativo para as pequenas empresas } \\
\text { - Recursos para investimento fundamentalmente próprios } \\
\text { - Nível elevado de dificuldade para investir com recursos próprios } \\
\text { - Investimentos insuficientes ou parcialmente insuficientes na área tecnológica } \\
\text { - Investimentos direcionados fundamentalmente para realização de melhorias } \\
\text { - macroeconômicos dependentes da capacidade de oferta e de fatores } \\
\text { - Obtenção de financiamentos não é uma grande dificuldade para as empresas } \\
\text { - pificuldade para obtenção de financiamentos é maior para empresas } \\
\text { - Baixa propensãonais } \\
\text { - Baixa propensão ao investimento em projetos de novos produtos }\end{array}$ \\
\hline & $\begin{array}{c}\text { Recursos } \\
\text { Humanos } \\
\text { e } \\
\text { Físicos }\end{array}$ & $\begin{array}{l}\text { Humanos: capacitação para produção e desenvolvimento de produtos } \\
\text { - Grau de qualificação para as atividades operacionais na produção é } \\
\text { considerado suficiente } \\
\text { - Grau de qualificação para as atividades de inovação é considerado } \\
\text { insuficiente } \\
\text { - Dificuldade de disponibilidade de mão-de-obra especializada no mercado } \\
\text { - Poucos engenheiros nas atividades de fabricação, PCP, qualidade e } \\
\text { desenvolvimento de produtos } \\
\text { Físicos: máquinas e Equipamentos } \\
\text { - Grau de atualização de máquinas e equipamentos é parcial. } \\
\text { - Presença de muitas máquinas convencionais, sem automatização. } \\
\text { - Recessidade de substituição de máquinas ou equipamentos obsoletos. } \\
\text { Redução do custo operacional e aumento de capacidade produtiva são os } \\
\text { principais objetivos para a substituição }\end{array}$ \\
\hline & $\begin{array}{l}\text { Engenharia de } \\
\text { Produto }\end{array}$ & $\begin{array}{l}\text { - P\&D não estruturado } \\
\text { - Predominância de inovações incrementais em empresas nacionais } \\
\text { - } \quad \text { Poucas inovações para o mercado nacional por empresas nacionais } \\
\text { nacional, mas existentes no merçodes incrementais novas para o mercado } \\
\text { - P\&D não é vista como obstáculo principal ao desenvolvimento da empresa } \\
\text { - Empresas transnacionais realizam predominantemente melhorias e } \\
\text { adaptações de produtos. O desenvolvimento de novos produtos é realizado } \\
\text { nas matrizes. } \\
\text { - Baixa frequência de atividades de engenharia reversa } \\
\text { - Projeto de produto predominantemente especiais (customizados) }\end{array}$ \\
\hline & $\begin{array}{c}\text { Engenharia da } \\
\text { Qualidade }\end{array}$ & 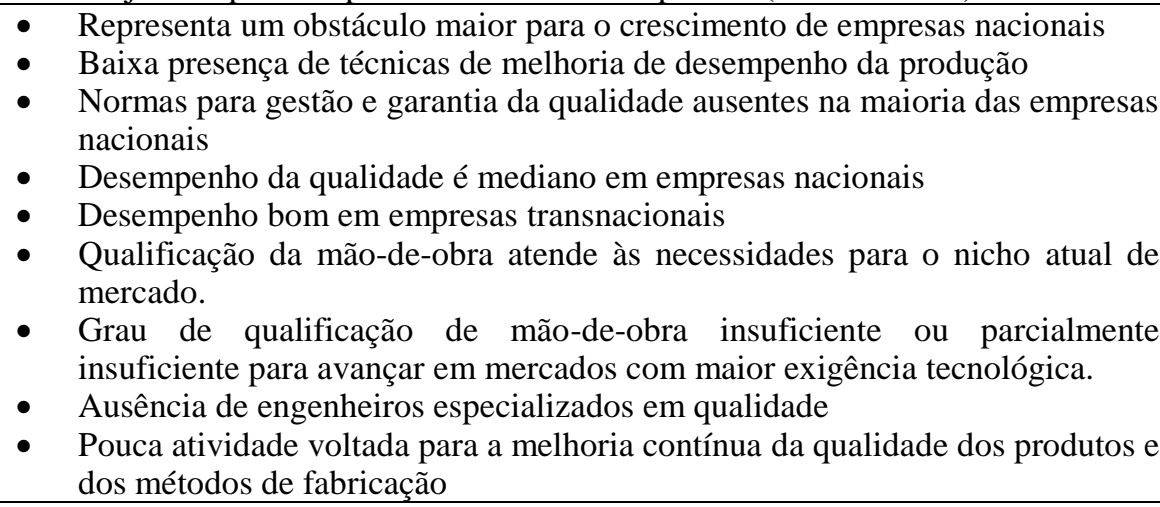 \\
\hline
\end{tabular}

No que tange aos recursos físicos, o grau de atualização internacional de máquinas e equipamentos é parcial. Há empresas que operam com máquinas convencionais não integradas a um sistema de automatização. Máquinas mais avançadas do ponto de vista tecnológico resultam em maior repetibilidade, maior precisão e maior produtividade, que por 
sua vez geram produtos de maior qualidade e custos de fabricação menores, fatores estes, fundamentais para a competitividade das empresas.

Quadro 14: Sistematização das características apresentadas pelos determinantes internos e externos da capacidade tecnológica nas empresas pesquisadas (continuação)

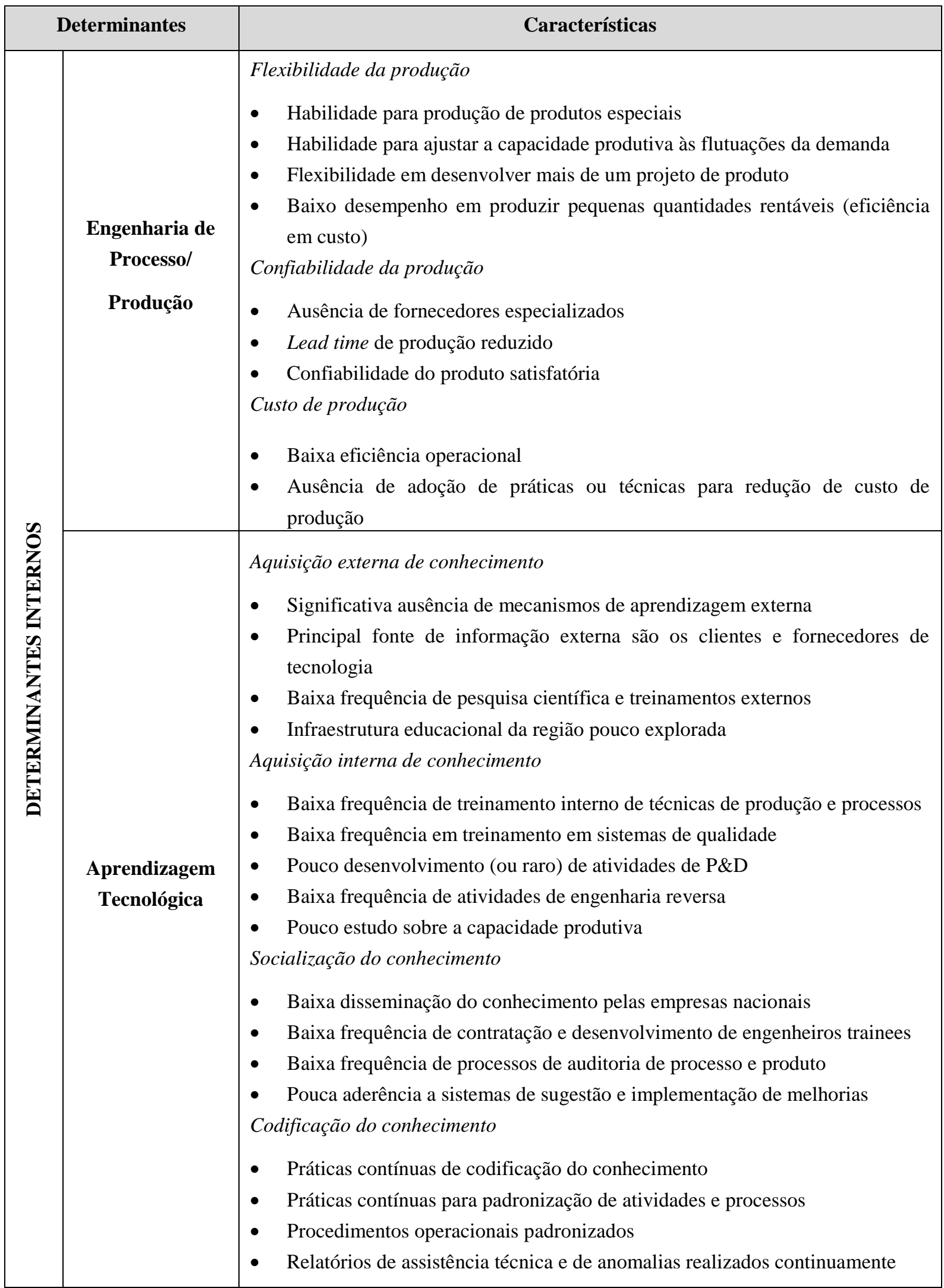


Quadro 14: Sistematização das características apresentadas pelos determinantes internos e externos da capacidade tecnológica nas empresas pesquisadas (continuação)

\begin{tabular}{|c|c|c|}
\hline & Determinantes & Características \\
\hline 要 & $\begin{array}{c}\text { Padrão de comportamento } \\
\text { para a inovação }\end{array}$ & $\begin{array}{l}\text { Estratégia } \\
\text { - Reconhecimento da inovação como elemento estratégico } \\
\text { - } \quad \text { Ausência ou uso limitado de ferramentas de prospecção } \\
\text { tecnológica } \\
\text { - Visão compartilhada dos principais executivos sobre o } \\
\text { desenvolvimento da empresa pela inovação } \\
\text { Processos } \\
\text { - Flexibilidade no desenvolvimento de produto } \\
\text { - Processo de DP organizado e apropriado } \\
\text { - } \quad \text { Ausência de mecanismos eficazes para compreender as } \\
\text { necessidades dos clientes } \\
\text { - Pouco envolvimento prévio de todos os departamentos no DP } \\
\text { Organização } \\
\text { - Bom ambiente para trabalho em equipe além dos limites } \\
\text { - Comunicação regular através da organização } \\
\text { - Ambiente organizacional pouco rígido } \\
\text { Interação e ações conjuntas } \\
\text { - } \quad \text { Ausência ou baixa interação com universidades } \\
\text { - Divergências com universidades em relação à propriedade } \\
\text { intelectual } \\
\text { - Forte presença de barreiras culturais para ações conjuntas } \\
\text { - } \text { Forte presença de barreiras jurídicas para ações conjuntas } \\
\text { Dificuldade de encontrar pessoas com conhecimento } \\
\text { especializado }\end{array}$ \\
\hline 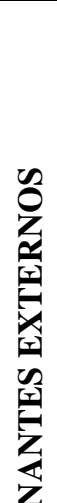 & Fatores macroeconômicos & $\begin{array}{l}\text { - Inibem investimentos em capacitação tecnológica } \\
\text { - } \quad \text { Mitigam atividades externas para fortalecimento dos processos } \\
\text { de aprendizado a partir de fontes externas } \\
\text { - Influencia fortemente o desempenho das empresas no mercado } \\
\text { interno e externo } \\
\text { - Política cambial: inviabiliza ou dificulta a exportação } \\
\text { - Carga tributária: eleva fortemente de custo de produção e } \\
\text { - Cargiculta a competitividade interna } \\
\text { - } \text { Cualificada } \\
\text { - Custo logístico: pouco representativo para o mercado interno } \\
\text { - Custico: muito representativo para o mercado externo }\end{array}$ \\
\hline 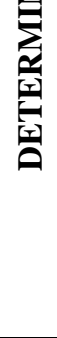 & $\begin{array}{c}\text { Sistema setorial de bens de } \\
\text { capital }\end{array}$ & 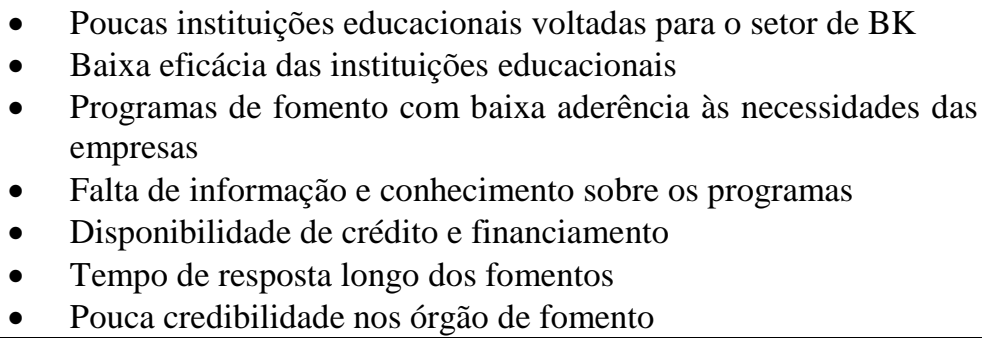 \\
\hline
\end{tabular}

Fonte: Elaborado a partir de pesquisa de campo

Em termos de recursos financeiros, as empresas não apresentam maiores dificuldades em disponibilizar capital de giro próprio para as operações diárias e de rotina. No entanto, para investir com recursos próprios em projetos de novos produtos, máquinas, qualificação de 
pessoal, entre outros, o nível de dificuldade apresentado pelas empresas é elevado. Em muitos casos, embora se tenha um incremento em investimento na área tecnológica, os montantes são ainda considerados insuficientes ou parcialmente suficientes. É importante destacar que as empresas, de maneira geral, não apresentam maiores dificuldades em obter financiamento para os projetos de inovação. Entretanto, verifica-se uma baixa propensão ao risco e ao investimento em novos produtos. Os projetos, fundamentalmente, são voltados para a realização de melhorias. A incerteza na capacidade de oferta e os riscos relacionados a fatores macroeconômicos inibem os investimentos, de maneira geral.

Quanto à engenharia de produto, observa-se que as empresas não apresentam uma estrutura organizada em pesquisa e desenvolvimento. Considerando que o foco das empresas recai essencialmente na realização de melhorias, a falta de uma estrutura de P\&D não é vista, pelos respondentes, como um obstáculo importante para o crescimento das empresas. Em muitos casos as atividades de $\mathrm{P} \& \mathrm{D}$ não são contínuas e não possuem pessoal dedicado exclusivamente ao desenvolvimento de novas soluções tecnológicas. Nota-se também uma baixa frequência em atividades contínuas de engenharia reversa. A baixa frequência de atividades de $P \& D$ e a ausência de uma estrutura formal, verificada nas empresas, inibe a aquisição de novos conhecimentos tácitos, os quais são fundamentais para os processos de aprendizagem, que por sua vez, conduzem ao acúmulo de capacidade tecnológica, conforme destacado em Figueiredo (2003).

Para os fabricantes nacionais, os principais incrementos tecnológicos incorporados nos produtos são novos para as empresas, mas já existentes no mercado nacional. As inovações para o mercado nacional são realizadas, em grande parte, pelas empresas transnacionais, e frequentemente desenvolvidas nas matrizes. Vale lembrar que as subsidiárias estrangeiras realizam no Brasil predominantemente melhorias e adaptações de produtos. Em outros termos, a baixa intensidade de esforços em atividades de P\&D nas empresas instaladas no Brasil retarda o acúmulo de capacidade tecnológica. Esse retardamento aumenta a diferença tecnológica (ou gap tecnológico) em relação às empresas inovadoras, já que a trajetória de acumulação de capacidade tecnológica, em fabricantes nacionais, se inicia quando as empresas inovadoras, já acumularam estoque substancial de capacidade tecnológica.

A engenharia da qualidade, em seu desempenho, pode ser avaliada a partir da exigência tecnológica dos nichos de mercado em que as empresas atuam. Vale lembrar que a qualidade, como habilidade técnica, é um processo de mudança técnica incremental, e que para a maioria das empresas da amostra, é uma componente chave para a estratégia de concorrência baseada 
na diferenciação. De acordo com Toledo (1990), considerando que o mercado competitivo das empresas baseia-se fundamentalmente na heterogeneidade de produtos, a diferenciação tornase um elemento crucial para a competitividade, pois pode complementar ou substituir a concorrência por preços.

De maneira geral, o desempenho da qualidade é considerado bom para as empresas transnacionais, e mediano para as empresas nacionais. No entanto, ao se considerar nichos de mercado mais exigentes, os processos de produção e a qualificação da mão-de-obra são percebidos como insuficientes ou parcialmente suficientes. Verifica-se uma baixa presença de técnicas de melhoria de desempenho da produção e de normas de gestão e garantia da qualidade, pouca atividade voltada para a melhoria contínua em produtos e processos, e ausência, em grande parte das empresas, de engenheiros especializados na área, especialmente em empresas nacionais.

Vale destacar que há empresas em que a necessidade de melhoria da qualidade está mais voltada para os aspectos do produto, e requerem melhorias quanto à conformidade às especificações técnicas. Entretanto, para outras empresas, o foco da qualidade é direcionado para os processos, no qual se busca uma melhoria em sua capacidade com a redução de sua variabilidade permitida.

Quanto à engenharia de processo/produção, verifica-se um conjunto de aspectos positivos relacionados à flexibilidade e à confiabilidade da produção. De maneira geral, as empresas possuem habilidades importantes para a produção de produtos especiais e para ajustar a capacidade produtiva às flutuações da demanda. Outro aspecto positivo é a flexibilidade que o sistema de desenvolvimento de produto das empresas apresenta em desenvolver pequenos projetos paralelos aos que se encontram já em andamento. Por outro lado, as empresas possuem baixa eficiência em custo, ou seja, quando apresentam dificuldades em produzir pequenas quantidades rentáveis.

No que se refere à confiabilidade, de maneira geral o desempenho é considerado satisfatório, com destaque para lead time de produção reduzido e as entregas no tempo prometido. Vale destacar que a eficiência na entrega e no tempo de produção deve-se ao elevado grau de verticalização da produção apresentado por uma parcela de empresas. Por outro lado, para outra parcela de empresas o desempenho nesses fatores é baixo e está diretamente relacionado à ausência de fornecedores especializados. 
Quanto aos custos de produção as empresas apresentam baixa eficiência operacional. Contribuem para tal, a ausência de adoção de práticas ou técnicas voltadas para a redução do custo operacional.

Em relação à aprendizagem tecnológica, observa-se para diversos mecanismos de aprendizagem externa, interna e de socialização do conhecimento, uma baixa intensidade nas atividades relacionadas. As práticas contínuas com maior frequência são aquelas relacionadas à codificação do conhecimento. Os processos de aprendizagem ocorrem nas empresas, de maneira geral, esporadicamente, e tal intensidade não é suficiente para levar as empresas a uma efetiva aquisição de conhecimento e nem à sua incorporação no plano organizacional. As atividades, quando contínuas, possibilitam a criação, a atualização e o aperfeiçoamento dos processos de aprendizagem ao longo do tempo, garantem um fluxo constante de saber externo da empresa; fazem com que se compreenda melhor a tecnologia adquirida e os princípios inerentes aos processos de aquisição de conhecimentos internos; e asseguram a constante conversão de aprendizagem individual em aprendizagem organizacional.

Dado o caráter complexo e sistêmico dos processos de aprendizagem, o uso de apenas um ou outro mecanismo, por mais eficientes que sejam, como a interação com clientes e fornecedores, ou treinamento interno de técnicas de produção e processo, não são suficientes para promover a aprendizagem organizacional. É necessário aprimorar continuamente uma variedade de mecanismos em todos os níveis da empresa, para rotinizar a conversão de aprendizagem individual em aprendizagem organizacional.

Para países, caracterizados por uma industrialização tardia, como o Brasil, os processos de aquisição de saber externo e interno são cruciais para as empresas, já que elas não podem valer-se de uma base de conhecimento previamente adquirida. Tanto os processos de aquisição quanto de conversão são fundamentais para a acumulação de sua competência tecnológica (FIGUEIREDO, 2003).

No que se refere ao padrão de comportamento para a inovação, observa-se uma determinada heterogeneidade nas dimensões analisadas. Um aspecto importante a ser destacado é o reconhecimento da inovação como elemento estratégico e a visão compartilhada dos principais executivos sobre o desenvolvimento da empresa pela inovação. Por outro lado, nota-se uma ausência ou uso muito limitado de ferramentas de prospecção tecnológica, fundamentais para a formulação e desdobramento das estratégias de inovação. 
Quanto aos processos, verificam-se importantes potencialidades, como a flexibilidade e organização apropriada nos processos de desenvolvimento de produtos. Por outro lado, apesar de existir uma interação contínua com clientes, as empresas carecem de mecanismos eficazes para compreender suas necessidades. Os processos de desenvolvimento de produtos, embora sejam organizados, concentram-se, de maneira geral, no próprio departamento, ou seja, não há um envolvimento prévio maior de outros departamentos no desenvolvimento de produto. As organizações, em sua maioria, são flexíveis e possuem uma estrutura adequada para tomar decisões rapidamente. $\mathrm{O}$ ambiente de trabalho em equipe além dos limites departamentais, considerado outro aspecto positivo, mas a eficiência na comunicação e nas atividades através da organização apresenta limitações.

As características menos favoráveis, no que diz respeito ao comportamento inovador, são verificadas nas interações e ações conjuntas. Observa-se que as empresas pouco interagem com outras empresas e/ou instituições. A relação com as universidades são limitadas e divergentes, em muitos casos. Há barreiras culturais e jurídicas que inibem a troca de experiências e de conhecimento entre os atores.

As interações e o desenvolvimento de ações conjuntas são cruciais para a aquisição de conhecimento externo. Conforme já destacado, o desenvolvimento de ações conjuntas leva a aquisições de conhecimentos tácitos e codificados, fundamentais para a criação e acúmulo de competência tecnológica.

No que tange aos elementos externos, tanto os fatores macroeconômicos quanto os relacionados ao sistema setorial representam importantes barreiras ao processo de acumulação de capacidade tecnológica e ao crescimento das empresas. Conforme já destacado, o acúmulo de capacidade tecnológica não está atrelado apenas aos processos intraorganizacionais, há condições externas à empresa que estimulam ou não os processos de aprendizagem e as estratégias para acúmulo de capacitações.

O comportamento dos fatores macroeconômicos inibe substancialmente os investimentos em recursos humanos e físicos para a capacitação. A elevada taxa de juros gera um custo alto para financiamento de equipamentos, bem como os encargos e impostos praticados criam barreiras para a contratação de mão-de-obra mais qualificada. Tais elementos são cruciais para a aquisição de novos conhecimentos e fortalecimento de outros processos de aprendizagem. 
O comportamento da taxa de câmbio representa para muitas empresas um risco econômico importante e restringe fortemente as políticas das empresas voltadas para a capacitação tecnológica e inovação, reduzindo os gastos nessa área.

O sistema setorial de inovação apresenta deficiências, em especial no que se refere a interação das empresas com a infraestrutura educacional. Há poucas instituições direcionadas ao setor de bens de capital. As interações se limitam a troca de informações, com baixa intensidade de ações conjuntas. Na concorrência pela inovação de produtos, conforme destacado por Ferraz et al. (1997), as relações com a infraestrutura científica e tecnológica constituem recurso fundamental para a competitividade da empresa.

Há questões culturais e jurídicas, conforme já exposto, que de certa forma inibem o fortalecimento das relações. A limitação de ações conjuntas afeta o processo de aprendizagem e posterior atualização tecnológica.

Os programas de fomento apresentam baixa aderência às necessidades das empresas. As condições de financiamento excluem muitas empresas, seja pelo tempo de resposta longo para aprovação e liberação dos recursos, seja pelo montante disponibilizado.

\subsubsection{Implicações para a competitividade no mercado interno e externo}

A partir das características apresentadas nas dimensões da capacidade tecnológica e das analises realizadas, é possível fazer algumas considerações das implicações para a competitividade no mercado interno e externo.

No que se refere ao mercado externo, conforme já exposto, a maioria das empresas destina alguma parcela de sua produção para o exterior. No entanto, muitas empresas não exportam ou deixam de exportar por apresentarem baixos níveis de competitividade, decorrentes dos custos elevados de produção, da mão-de-obra e baixa escala de produção; elevado grau de especialização do produto; infraestrutura para comercialização; baixa capacidade produtiva; presença de grandes fabricantes mundiais; e de aspectos macroeconômicos, como a valorização cambial.

A infraestrutura pós-venda, composta por elementos técnicos e comerciais, é relacionada pelos respondentes como um dos principais fatores que geram dificuldades para competir no mercado externo, e a necessidade de assistência técnica e de peças de reposição é intrínseca ao tipo de produto. A assistência técnica precisa dispor de profissionais qualificados para o atendimento e as peças de reposição, de estoques para disponibilidade imediata. Torna-se 
necessário também a criação de uma área comercial dedicada à exportação, com profissionais específicos à ocupação.

O custo de manutenção de uma infraestrutura técnica e comercial é elevado e o baixo volume de vendas externas, apresentado pelas empresas não justifica os investimentos necessários. É importante ressaltar que em mercados com maior demanda estão presentes empresas globais, que possuem produtos de qualidade e preços mais competitivos.

Para mercados mais exigentes, em termos tecnológicos, como a Europa, em especial a Alemanha e Itália, e América do Norte, em especial os EUA, são poucas as empresas que destinam parcela de suas vendas para essas localidades; e que 65\% dessas empresas são transnacionais, ou seja, somente pouco mais de um terço das empresas, que exportam paras mercados mais exigentes em tecnologia, são de origem nacional.

Em relação ao volume de vendas, a participação é muito pequena, para a grande maioria das empresas. As exportações, para considerável número de empresas, não superam 5\% do volume de suas vendas. As dificuldades apresentadas para competir no mercado externo são várias, mas podem ser sintetizados em tecnologia, custos para exportação e infraestrutura pósvenda (comercial e técnica).

A tecnologia é apontada como um fator decisivo, em especial, para atuar em mercados da Europa e Estados Unidos da América (EUA). Nesses mercados a exigência de sofisticação técnica é muito maior quando comparada a outros mercados, como a da América Latina, África, leste europeu, África e Oriente Médio. Para a incorporação de tecnologias mais avançadas, os custos de inovação, os recursos humanos para as atividades de inovação, e estrutura de $\mathrm{P} \& \mathrm{D}$, são apontados como as principais dificuldades. Vale destacar que para as empresas transnacionais o incremento de novas tecnologias está atrelado às decisões estratégicas da matriz, a qual centraliza todas as atividades de $\mathrm{P} \& \mathrm{D}$ a para inovação, além de determinar a atuação geográfica das subsidiárias. Em outros termos, o desenvolvimento e o incremento de tecnologias no caso de empresas transnacionais estão relacionados fundamentalmente às restrições da matriz, por questões estratégicas.

Um segundo fator está relacionado ao custo para exportação. Segundo os respondentes, os elevados custos logísticos de transporte e armazenagem, custos de fabricação (matériasprimas, mão-de-obra, energia elétrica) e o câmbio valorizado, geram importantes dificuldades em viabilizar as exportações. Tais condições fazem com que a rentabilidade e o lucro das empresas sejam pequenos ou inviáveis, inibindo assim as vendas externas. 
Vale ressaltar que os custos de fabricação e o câmbio valorizado também afetam a competitividade das empresas no mercado interno, em especial no que se refere aos produtos importados. Nesse caso, conforme declarado pelos respondentes, tal contexto torna o produto nacional, em muitos casos, mais caro que o importado. Para as empresas que competem no mercado por preço e que não apresentam outros diferenciais competitivos, tem sua participação no mercado interno comprometida.

Sendo assim, é importante enfatizar que as dificuldades em exportar, bem como a tomada de decisão em investir no mercado externo, não dependem exclusivamente de um ou outro fator, mas do conjunto deles. De outra forma, a dificuldade em competir no mercado externo não recai somente sobre aspectos tecnológicos, que envolvem recursos humanos, financiamento, produção, produto, estrutura de $\mathrm{P} \& \mathrm{D}$, etc., e aspectos comerciais do produto.

As condições macroeconômicas representam um fator externo importante e, para muitas empresas, pode representar um forte inibidor dos investimentos necessários para estimular as exportações. Em outros termos, apesar de a inovação poder gerar produtos mais competitivos, do ponto de vista tecnológico, por si só não garante o sucesso comercial, já que este envolve outros elementos competitivos, tais como preço e serviços pós-venda, os quais podem ser afetados fortemente por condições internas e externas às empresas. Particularmente, em termos de inovação tecnológica, esse contexto, conforme enfatizado por Ferraz, Kupfer e Haguenauer (1995), força as empresas a deixar de investir em P\&D, o que por sua vez, gera perdas notáveis de capacidades inovativas adquiridas.

Outro fator relatado pelos respondentes que gera uma dificuldade em competir tanto no mercado interno como no externo inclui a valorização da marca. Essa dificuldade incide fortemente nas empresas nacionais e aquelas presentes há pouco tempo no mercado. Do total de empresas transnacionais, 71,4\% existem no mercado há pelo menos 40 anos, sendo que 14,3\% há mais de cem. Quanto às empresas nacionais, 38,5\% foram fundadas há mais de 40 anos e aproximadamente $20 \%$ existem há menos de 20 anos. As empresas transnacionais garantem uma vantagem maior nesse sentido, pois maior tempo de mercado ajuda a consolidar a marca. No entanto, a valorização da marca não está relacionada somente ao tempo de mercado, mas também ao país de origem. Países como Alemanha, EUA, Itália e Japão, são detentores de tecnologias avançadas, possuindo as principais empresas lideres em inovação no setor. A condição de liderança tecnológica desses países, no setor de bens de capital, gera maior confiabilidade no produto e cria uma barreira competitiva para empresas brasileiras. 
A competitividade das empresas do setor de bens de capital no mercado interno e no mercado externo não é caracterizada apenas por fatores inerentes ao tipo de mercado. Há fatores comuns que afetam ambos os mercados.

Uma consideração importante a se fazer em relação ao produto diz respeito à escala de produção. A escala de produção é um fator-chave para a competitividade seja no mercado interno ou externo. No entanto, sua possibilidade está diretamente relacionada ao grau de especialização do produto ou grau de customização. Para produtos com grau muito elevado de especialização a produção se distancia mais de uma escala de produção, pois a mesma requer soluções específicas e trabalho especializado, muitas vezes para produtos únicos. As empresas da amostra, fundamentalmente, oferecem produtos com grau elevado de especialização, principalmente em empresas nacionais e de porte menor. As empresas transnacionais, apesar de terem produtos ainda considerados não seriados, o grau de especialização é muito menor, o que possibilita uma produção em determinada escala.

As principais dificuldades, considerando as características do produto das empresas, que conduzem a uma menor capacidade de competir no mercado nacional, identificadas na amostra, estão relacionadas tanto a fatores internos como externos à organização. Os fatores internos dizem respeito à produção, capacitação da mão-de-obra e infraestrutura física. Os fatores externos, por sua vez, estão relacionados às políticas tributária, comercial e cambial, e clientes.

Em relação à produção, o baixo volume é considerado como a grande barreira para uma melhor competitividade tanto para o mercado interno como para o externo. Para empresas de grande porte, em especial, a escala de produção é de fundamental importância não apenas para uma redução do custo médio e oferecer um produto mais competitivo em preço, mas também para superar os custos fixos de manutenção da infraestrutura física e de pessoal, que são muito elevados.

Outro problema apontado refere-se à flexibilidade da produção. Para muitas empresas não há um consumo regular de seus produtos. Influências constantes de fatores macroeconômicos criam determinadas sazonalidades de consumo interno, o que por sua vez gera uma grande dificuldade em ajustar a produção com a demanda. De acordo com os respondentes, um volume maior de exportações minimizaria os efeitos sazonais ou de uma crise interna. Vale lembrar que para 90\% das empresas a concentração de vendas está no mercado interno, com pouco volume destinado às exportações. Uma empresa que atua não apenas no mercado 
interno, em momentos de crise interna ou de períodos sazonais, possui capacidade de minimizar os efeitos negativos e não interromper o crescimento da empresa.

Quanto à mão-de-obra, dois aspectos são considerados. O primeiro refere-se ao custo de manutenção de pessoal e o segundo a qualificação. Conforme mostrado, os encargos e salários aliados a um nível de qualificação intermediário geram uma importante barreira ao crescimento das empresas. O custo elevado da mão-de-obra contribui para um custo operacional elevado. A qualificação da mão-de-obra embora satisfaça, do ponto de vista operacional, encontra-se abaixo do nível desejado para maior eficiência produtiva e desenvolvimento de projetos de melhorias e de novos produtos. Conforme apresentado, $51 \%$ das empresas declararam que necessitam de profissionais de engenharia, voltados principalmente para a melhoria do planejamento e controle da produção. Para a maioria dos respondentes, os níveis de qualidade precisam ser melhorados e os custos operacionais e de produção reduzidos, para atingirem maiores níveis de competitividade.

A infraestrutura física é um recurso importante e que reflete na capacidade de competir. Conforme já relatado, $45 \%$ das empresas necessitam de substituição de máquinas e equipamentos para a produção. A atual infraestrutura em máquinas e equipamentos, para essas empresas, influenciam diretamente na qualidade dos produtos, na produtividade, e na flexibilidade da produção. Em muitos casos as máquinas operatrizes são convencionais, com pouca disponibilidade em máquinas que operam por Comando Numérico Computadorizado (CNC). Para empresas do setor de bens de capital, na qual a usinagem faz parte da concepção do produto, as máquinas CNC são de fundamental importância, pois possibilita a criação de peças com geometrias de extrema complexidade (comuns para o setor), a redução de tempo de produção, aumento da precisão, aumento da repetibilidade na fabricação das peças, e redução de falhas humanas. 


\section{CONSIDERAÇÕES FINAIS}

Esta pesquisa teve como propósito principal investigar os principais elementos internos e externos à empresa, que são determinantes para o acúmulo de capacidade tecnológica em empresas do setor de bens de capital. O desdobramento em elementos internos e externos possibilitou a avaliação dos esforços internos realizados pelas empresas e as limitações de acúmulo de capacidade tecnológica postas pelos condicionantes externos. A exploração desses elementos internos e externos implicou a construção de uma sistematização das principais dimensões que compõem a capacidade tecnológica apresentada pelas empresas.

A análise dos determinantes mostrou que em todas as dimensões as características apresentadas condicionam as empresas a uma baixa competitividade, seja por preço ou tecnologia. Do ponto de vista dos elementos internos, é crucial para a sobrevivência e competitividade, em um mercado globalizado, que as empresas se engajem em processos contínuos de aprendizagem para a construção e acúmulo de sua capacidade tecnológica. Vale lembrar que a capacidade tecnológica é o ponto de partida para os investimentos em recursos substanciais em pesquisa e desenvolvimento.

Por outro lado, do ponto de vista dos elementos externos, as interrupções do ciclo de aprendizagem, determinadas pelas flutuações do crescimento econômico, contribuem para a ruptura da sequência evolutiva e cumulativa do processo de acúmulo de capacidade tecnológica. Em outros termos, a análise sugere que os elementos externos exercem forte influência no referido processo por criarem condições desfavoráveis para investimentos, em particular, aqueles realizados com atividades com longo prazo de retorno, como as de P\&D e inovação.

Quanto à heterogeneidade, pode-se afirmar que está presente nas empresas, nos setores atendidos por elas e nos níveis tecnológicos dos produtos. Há condições e especificidades quanto ao porte e origem das empresas. As empresas nacionais e de pequeno porte apresentam, de maneira geral, maiores dificuldades para o acúmulo capacidade tecnológica, pois são mais sensíveis às mudanças no ambiente. As empresas transnacionais e as nacionais de médio e grande portes, em grande parcela, apresentam um número maior de práticas contínuas que favorecem os processos de aprendizagem e o acúmulo de capacitações tecnológicas. Em especial, as empresas nacionais encontram maior dificuldade na exportação, pois o efeito dos fatores macroeconômicos sobre elas é maior. 
A indústria de bens de capital apresenta características que concorrem para inibir a realização de atividades tecnológicas. Conforme exposto, há uma carência de especialização da produção, uma falta de escala, elevados custos unitários, baixa utilização de automação dos processos, e uma estrutura empresarial limitada. Tais características inviabilizam a competitividade das empresas, seja no mercado interno e externo.

Por outro lado, as empresas pesquisadas, embora encontrem alguma dificuldade em produzir e comercializar, de maneira geral, demonstram boa capacidade de fabricação, adaptação e realização aperfeiçoamentos marginais. Entretanto, quando do projeto de produtos mais sofisticados, dependem da importação de tecnologia.

Em relação às políticas públicas, a atual política industrial e tecnológica brasileira dispõe de um conjunto de modalidades e programas. Há fomentos à inovação direcionados para a pesquisa científica e tecnológica; para a formação de recursos humanos; inovação na produção; para fortalecimento da engenharia; para inserção no comercio internacional; para incentivo à inovação; para modernização de máquinas e equipamentos, entre outros. Pode-se afirmar que, em princípio, os instrumentos de política pública cobrem muitas das necessidades apresentadas pelas empresas nas dimensões internas e externas para o acúmulo da capacidade tecnológica. Entretanto, é importante ressaltar que, apesar do aumento do número de empresas beneficiadas pelos programas e pela sua amplitude, a aderência é considerada baixa.

A baixa aderência está relacionada a vários fatores. As políticas públicas para a promoção de empresas inovadoras, de maneira geral, são homogeneizadas e diante de um setor muito heterogêneo e de especificidades organizacionais, conforme visto, torna-se necessário uma maior especialização tanto das agências de fomento quanto dos programas. A ausência de um tratamento especializado para o setor de bens de capital dificulta o acesso aos programas e submete os projetos de inovação das empresas do setor a outras divisões setoriais.

Por outro lado, quanto às empresas, é importante destacar a falta de informação sobre os programas e o pouco conhecimento em relação às questões da inovação. Conforme visto, as empresas apresentam uma baixa capacitação para o aprendizado tecnológico. Tal contexto tem gerado pouca aderência aos estímulos lançados pela política de inovação.

Seja pela falta de informação, pelo modelo de inserção ou pelo pouco conhecimento das empresas sobre as questões da inovação, as políticas públicas voltadas para promover a capacitação tecnológica e inovação nas empresas têm apresentado resultados aquém do 
necessário e desejado. As empresas nacionais são as que apresentam maior necessidade. A viabilidade em projetos voltados para incorporação de tecnologias avançadas requer fortemente o apoio do Estado. Vale lembrar que os projetos de inovação apresentam elevados custos e riscos mercadológicos, e as empresas nacionais, em especial as de pequeno e médio portes, não dispõem de recursos próprios suficientes.

Considerando a importância do preço e da tecnologia embutida nos equipamentos como fatores de competitividade, é crucial para as empresas o aumento da capacidade tecnológica e a adoção de práticas que conduzam à redução de custo. Políticas públicas que fortaleçam o apoio à tecnologia de produto, no sentido de estimular a engenharia de produto, por meio de financiamento subsidiado, são fundamentais para o acúmulo da capacidade tecnológica das empresas. Além do acúmulo de capacidade tecnológica, há necessidade de uma maior modernização dos equipamentos das empresas; maior capacitação comercial, em especial no que se refere ao serviço pós venda; maior capacitação produtiva, com ênfase na qualidade; e internacionalização das empresas nacionais.

\subsection{Limitações da pesquisa e sugestões para trabalhos futuros}

Quanto às limitações desta pesquisa, a principal atenção deve-se à dificuldade de generalização. Tal dificuldade não está relacionada apenas ao tamanho da amostra, mas também à heterogeneidade apresentada pelo setor. A amostra caracterizou-se pelas diferenças apresentadas quanto aos produtos, aos mercados de atuação, ao porte e a origem das empresas. Há indicativos de comportamentos diferentes entre empresas nacionais e transnacionais, mas por outro lado, há fatores que apresentam comportamentos comuns às empresas. Nesse sentido, uma ampliação no número de respondentes seria importante para a confirmação das similaridades e diferenças.

Outra limitação refere-se às variáveis escolhidas para o estudo. A abordagem sobre capacidade tecnológica é extensa e apresenta outras variáveis que podem ser incluídas para complementar as análises e resultados obtidos.

Um aspecto importante a ser considerado para estudos futuros diz respeito às relações entre as variáveis. As análises realizadas das dimensões internas e externas sobre o acúmulo das capacidades tecnológicas sugerem relações entre variáveis, e nesse sentido, um estudo com uma amostragem significativa e com uso de ferramentas de análise multivariada, traria um entendimento melhor dos determinantes e de suas interrelações. 


\section{REFERÊNCIAS}

AAKER, D. A. Developing Business Strategies. 5.ed. New York: Wiley, 1998.

ABERNATHY, W.J; UTTERBACK, J.M. Patterns of Industrial Innovation. Technology Review, V.80, N.7, p. 40-47, 1978.

ALBUQUERQUE, B.E. et al. O setor de bens de capital no Brasil e o papel do BNDES como indutor do desenvolvimento, no período 2003-2011. In: SOUSA, F.L. BNDES 60 anos: perspectivas setoriais. Rio de Janeiro: BNDES, 2012.

ALEM, A.C.; PESSOA, R.M. O setor de bens de capital e o desenvolvimento econômico: quais são os desafios? BNDES Setorial, Rio de Janeiro, n. 22, p. 71-88, set. 2005.

ALMEIDA, F.L. (1983) A Expansão da Indústria de Bens de Capital: Fatores Determinantes. Rio de Janeiro, Fundação Getúlio Vargas.

AMSDEN, A. H. The rise of the rest: Challenges to the West from late-industrializing economies, Oxford University Press, Oxford, 2001.

ARAÚJO, B. Estudos setoriais de inovação - Indústria de bens de capital: estudo sobre como as empresas brasileiras nos diferentes setores industriais acumulam conhecimento para realizar inovação tecnológica. Relatório Setorial: indústria de bens de capital. Agência Brasileira de Desenvolvimento Industrial (ABDI). Brasília: Ipea, 2009.

ARCHIBUGI D., Pavitt's taxonomy sixteen years on: a review article. Economics and innovation and new technology, vol. 10, p. 415-425, 2001.

ARCHIBUGI D., Coco A. Measuring technological capabilities at the country level: A survey and a menu for choice. Research Policy, 34 (2) , p. 175-194, 2005.

ARCHIBUGI, D.; CESARATTO, S.; SIRILLI, G. Sources of innovative activities and industrial organization in Italy. Research Policy, 20, 299-313, 1991.

ARIFFIN, N.The internationalisation of innovative capabilities: the malaysian electronics industry. D.Phil. Thesis, SPRU University of Sussex, Brighton, 2000.

ARNOLD, E.; BELL, M.; BESSANT, J.; BRIMBLE, P. Enhancing Policy and Institutional Support for Industrial Technology Development in Thailand: The Overall Policy Framework and the Development of the Industrial Innovation System. Relatório elaborado para a National Science and Technology Development Agency of Thailand por Technopolis, SPRU, Centrim, and Broker Group, 2000.

ARROW, K.J. "Economic welfare and the allocation of resources for invention." In: NELSON, R.R. (ed.) The Rate and Direction of Inventive Activity: economic and social fators, pp. 609-625: Disponível em http://www.nber.org/books/univ62-1, 1962.

BELL, M. Technological learning and the development of productive and innovative capacities in the industry and infrastructure sectors of the least developed countries: what's roles for ODA? Paper prepared for UNCTAD Division for Africa, Least Developed Countries Specialised Programme, Brighton, Science Policy Research, 2007 
Overheads and notes on lectures and seminars, Technology Development Course, MSc in Technololgy and Innovation Management Course, Brighton: SPRU, University of Sussex, 1997.

Technical change in infant industries: a review of the empirical evidence. Brighton: SPRU, University of Sussex, 1982.

BELL, M; PAVITT, K. The development of technological capabilities: technology and international competitiveness. Washington: The World Bank, 1995.

Technological Accumulation and Industrial Growth: Contrasts Between Developed and Developing Countries. Industrial and Corporate Change, V.2, n.1, p. 157-210, 1993.

BERGEK A., JACOBSSON, S., CARLSSON, B., LINDMARK, S., RICKNE, A. Analyzing the functional dynamics of technological innovation systems: A scheme of analysis. Research Policy, 37 (3), pp. 407-429, 2008

BRESCHI, S.; MALERBA, F. Sectorial system of innovation: technological regimes, Schumpeterian dynamics and spatial boundaries. In: Edquist, C.(Ed.). System of innovation. London: Francis Pinter, 1997.

BRESCHI, S.; MALERBA, F.; ORSENIGO, L.. Technological regimes and schumpeterian patterns of innovation. Economic Journal, v.110, p. 388-410, 2000.

BURGELMAN, R.A.; CHRISTENSEN, C.M.; WHEELWRIGHT, S.C. Strategic management of technology and innovation. McGraw-Hill, 2009.

BURNS, T; STALKER, G.M. The Management of Innovation. Oxford University Press, 1994.

CAMPOS, B; RUIZ, A. U. Padrões setoriais de inovação na indústria brasileira. Revista Brasileira de Inovação, v.8, n.1, p.167-210, 2009.

CANO, W.; GONÇALVES, A. L. Política industrial do Governo Lula. In: OS ANOS Lula: contribuições para um balanço crítico 2003-2010. Rio de Janeiro: Garamond, 2010.

CASTILHOS, C. C. Contradições e limites da política industrial do Governo Lula. Indicadores Econômicos FEE, v. 33, n. 1, p. 55-74, 2005.

CASTRO, A.B; SOUZA, F. E. P. A economia brasileira em marcha forçada. Rio de Janeiro: Paz e terra, v. 32, 1985.

CAVARZAN, G. M.; RACY, J.C.. "II PND: as peculiaridades da estratégia brasileira durante a crise internacional dos anos 70." Revista de Economia Mackenzie, v.8, n.3, p.52-66, 2011.

CIMOLI, M., DOSI, G., NELSON, R. R. ; STIGLITZ, J. Institutions and Policies Shaping Industrial Development: An Introductory Note, LEM Working Paper Series, 2006.

Instituições e políticas moldando o desenvolvimento industrial: uma nota introdutória. Revista Brasileira de Inovação, Rio de Janeiro, V.6, N.1, p.55-85, 2007. 
COHEN, W.M.; LEVINTHAL, D.A. Innovation and learning: the two faces of r\&d. The Economic Journal, N. 99, p. 569-596, 1989.

COSTA, V. M. G.; CUNHA, J. C. A universidade e a capacitação tecnológica das empresas. Revista de Administração Contemporânea, 5(1), 61-81, 2001.

CRESWELL, J.W. Projeto de pesquisa: métodos qualitativo, quantitativo e misto. Porto Alegre: Artmed, 2007.

DAHLMAN, C.; WESTPHAL, L.E. Technological effort in industrial development - an interpretative survey of recent research, in F. Stewart and J. James (Eds), The economics of new technology in developing countries, Frances Pinter, London. 1982.

DAHLMAN, C.; ROSS-LARSON, B.; WESTPHAL, L.E. Managing Technological Development: Lessons from the Newly Industrializing Countries. World Development, V. 15, N. 6, p. 759-775, 1987.

DE NEGRI, J. A.; SALERNO, M.S. (org.). Inovações, padrões tecnológicos e desempenho das firmas industriais brasileiras. Brasíla. IPEA, 2005.

DE NEGRI, J.A.; SALERNO, M. S.; CASTRO, A. B. Inovações, padrões tecnológicos e desempenho das firmas industriais brasileiras. In: DE NEGRI, J. A.; SALERNO, M.S. (org.). Inovações, padrões tecnológicos e desempenho das firmas industriais brasileiras. Brasília. IPEA, 2005.

DOSI,G. Sources, procedures and microeconomic effects of innovation. Journal of Economic Literature, v.26, p. 1120-1171, 1988.

Technological paradigms and technological trajectories: a suggested interpretation of the determinants and directions of technical change. Research Policy, v.11, n.3, p. 147-162, 1982.

DUTRÉNIT, G. Learning and knowledge management in the firm: from knowledge accumulation to strategic capabilities. Cheltenham: Edward Elgar, 2000.

EVANGELISTA, R., Sectoral Patterns of Technological Change in Services. Economics of Innovation and New Technology, v.9, p.183-221, 2000.

Ferraz, J.C.; Kupfer, D.; Haguenauer, L. Made in Brasil: desafios competitivos para a indústria. Rio de Janeiro: Campus, 1997.

FIGUEIREDO P. N. Aprendizagem tecnológica e inovação industrial em economias emergentes: uma breve contribuição para o desenho e implementação de estudos empíricos e estratégias no Brasil. Revista Brasileira de Inovação, v.3, nº 2, Jul/Dez, p. 323-61, 2004.

Gestão da inovação: conceitos, métricas e experiências de empresas no Brasil. Rio de Janeiro: LTC, 2009.

Aprendizagem tecnológica e performance competitiva. Rio de Janeiro: Editora FGV, 
FINEP. Relatório da Gestão da Finep 2003-2006. Disponível em: < http://www.finep.gov.br/numeros_finep/relatorio_atividades/relatorio_da_gestao_2003_a_20 06.pdf. >. Acesso em: 14/05/2014.

FORZA, C. Survey research in operations management: a process-based perspective. International Journal of Operations \& Production Management, V. 22, N.2, P. 152-194, 2002.

FRANSMAN, M. Technology and Economic Development, Wheatshead Books, Great Britain, 1986.

FREEMAN, C. Technology (1987). Policy and economic performance: lessons from Japan, London: Printer Publishers

FURTADO, J. Padrões de inovação na indústria brasileira. In: Seminário no Instituto Fernando Henrique Cardoso. 2004. Disponível em: http://www.inovacao.unicamp.br/report/inte-art_furtado.pdf. Acesso em 25 fev 2012.

FURTADO, A. (Coord.). Capacitação tecnológica, competitividade e política industrial: uma abordagem setorial e por empresas líderes. Brasília: IPEA, 1994.

GARCIA, R. A importância da dimensão local da inovação e a formação de clusters em setores de alta tecnologia. Ensaios FEE, v.22,n.1, p.143-160, 2001.

GODOI, C.K.; MELLO, R.B; SILVA, A.B. Pesquisa qualitativa em estudos organizacionais: paradigmas, estratégias e métodos. São Paulo. Saraiva, 2006.

GRANT R.M.; BADEN-FULLER, C. A Knowledge Accessing Theory of Strategic Alliances. Journal of Management Studies 41:1, p.61-84, 2004

HAYAMI, Y.; RUTTAN, V. Agricultural development: an international perspective, The Johns Hopkins Press, Baltimore, 1971.

HASENCLEVER, L.; MENDONÇA, C.E.R. Produção do conhecimento técnicocientífico e o sistema produtivo: uma revisão bibliográfica. Texto de debate n. 33, Universidade Federal do Rio de Janeiro, Rio de Janeiro, 1994.

HASENCLEVER, L.; CASSIOLATO, J. (1998). Capacitação tecnológica empresarial brasileira e transferência de tecnologia. Anais do Simpósio de Gestão da Inovação Tecnológica, 20 (p. 309-321). São Paulo: PGT/USP.

HELlER, C. Diversificação Tecnológica: a tecnologia como unidade do conceito de indústria. Revista Instituto Municipal de Ensino Superior de São Caetano do Sul, v. 21, p. 2842, 1991.

JARAMILLO, H.; LUGONES, G.; SALAZAR, M. Manual de Bogotá: normalización de indicadores de innovación tecnológica en América Latina y el Caribe. Bogotá, Colombia:OEA; RYCIT,2000.

JORGE, M. M. Competitividade do complexo celulose, papel e gráfica. In: Estudo da competitividade da indústria brasileira. Campinas: MCT/FINEP/PADCT, 1993. 
KANNEBLEY Jr., S.; PORTO, G.S.; PAZZELO, E.T. "Inovação na Indústria Brasileira: Uma Análise Exploratória a Partir da Pintec”. Revista Brasileira de Inovação. v. 3, n. 1, p. 87-128, 2004.

KATZ, J. (Ed). Technology generation in Latin American manufacturing industries, Macmillan Press, Basingstoke, 1987.

KENNY, J. Effective project management for strategic innovation and change in an organizational context. Project Management Journal. 34 (1); p.43, 2003.

KIM, L. Da imitação à inovação: a dinâmica do aprendizado tecnológico da Coréia. Campinas: editora da Unicamp, 2005.

KUPFER, D.; ROCHA, F. Determinantes setoriais do desempenho das empresas industriais brasileiras. In DE NEGRI, J. A.; SALERNO, M. S. Inovações, padrões tecnológicos e desempenho das firmas industriais brasileiras. Rio de Janeiro: Ipea, 2005.

LA ROVERE, R.L. Paradigmas e trajetórias tecnológicas. In: PALAEZ, V.; SZMRECSÁNYI, T. (org.). Economia da inovação tecnológica. São Paulo, SP. Editora Hucitec, 2006.

LALL, S. Technological capabilities and industrialization, World Development, Vol. 20, No. 2, p. 165-186, 1992.

A mudança tecnológica e a industrialização nas economias de industrialização recente da Ásia: conquistas e desafios. In: Kim, L; Nelson, R.R. Tecnologia, aprendizado e inovação: as experiências das economias de industrialização recente. Campinas: Editora da Unicamp, 2005.

The Technological Structure and Performance of Developing Country Manufactured Exports, 1985-98, Oxford Development Studies, V.28, n.3, p. 337-369, 2000.

Reinventing Industrial Strategy: The Role of Government Policy in Building Industrial Competitiveness. Annals of Economics and Finance, v. 14, n. 2, p. 785-829, 2013.

LAPLANE, M.F.; CASSIOLATO, J.E.; LASTRES, H. Projeto Política Brasileira de Ciência, Tecnologia e Inovação: A Lei de Inovação e o Sistema Nacional de C \& T \& I. CGEE, Rio de Janeiro, 2007

LARANJA, M. A inovação que não necessita de I\&D: sugestões para uma política de inovação tecnológica centrada na difusão e na procura. Análise Social, v.11, p. 319-343, 2005.

LEE, K. R. "The role of user firms in the innovation of machine tools: The Japanese case". Research Policy 25, p. 491-507, 1996

LUNDVALL, B.A. (ed.) National System os Innovation: towards a theory of innovation and interactive learning. London: Printer. 1992.

Políticas de Inovação na Economia do Aprendizado, Parcerias Estratégicas, n.10, 
LUNDVALL, B.A., VANG, J., JOSEPH, K.J. e CHAMINADE, C. (2009), Innovation system research and developing countries, in LUNDVALL, A.B., JOSEPH, K.J., CHAMINADE, C. and VANG, J. (eds.) Handbook of Innovation Systems and Developing Countries. Building Domestic Capabilities in a Global Setting. Edward Elgar, Cheltenham, UK and Northampton, MA, USA.

MALERBA, F. Innovation and the evolution of industries. Journal of Evolutionary Economics, v.16, n. 1-2, p. 3-23, 2006. 264,2002 .

Sectoral systems of innovation and production. Research Policy, v.31, n.2, p.247-

MALERBA, F; ORSENIGO, L. Technological regimes and behaviour. Industrial and corporate change, v.2, n.1, p.45-71, 1993.

MALERBA, F.; ORSENIGO, L. Schumpeterian Patterns of Innovation are TechnologySpecific, Research Policy, v.25, n. 3, p.451-478, 1996.

Technological regimes and sectorial patterns of innovative activities. Industrial and corporate change, v.6,n.1, p. 83-117, 1997.

MARSILI, O. The Anatomy and Evolution of Industries: Technological Change and Industrial Dynamics. Cheltenham, UK and Northampton, MA, USA: Edward Elgar, 2001.

MARSILI, O; VERSPAGEN, B. Technological regimes and Innovation: Looking for Regularities in Dutch manufacturing. Druid summer conference 2001, Aalborg, Denmark, 2001.

MARTINS, R. A. Abordagens quantitativa e qualitativa. In: Miguel, P.A.C (Org.) Metodologia de pesquisa em engenharia de produção e gestão de operações. Rio de Janeiro: Elsevier, 2010.

MATHEWS, J.A. From National Innovation Systems to National Systems of Economic Learning: The Case of Technology Diffusion Management in East Asia. Paper submitted to DRUID Summer conference National Innovation Systems, Industrial Dynamics and Innovation Policy, Rebild, Denmark, June 9-12, 1999.

MATOS, P. O. Análise dos planos de desenvolvimento elaborados no Brasil após o II PND. Dissertação de mestrado. Universidade de São Paulo, 2002.

MCT. Ciência, tecnologia e inovação para o desenvolvimento nacional: Plano de Ação 20072010. Ministério da Ciência e da Tecnologia, 2007. Disponível em: www.mct.gov.br. Acesso em 10/5/2014.

Relatório de Gestão 2003-2006. Ministério da Ciência e Tecnologia, 2007a. Disponível em: <ftp://ftp.mct.gov.br/Biblioteca/5956-Relatorio_gestao_jan.2003dez.2006.pdf. >. Acesso em 12/05/07.

MINTZBERG, H.; QUINN, J.(Eds.). The Strategy Process: Concepts, Context, Cases. 4.ed. New Jersey: Prentice-Hall, 2002. 
MODEL, S. Triangulation between case study and survey methods in management accounting research: An assessment of validity implications. Management Accounting Research, V. 16, p. 231-254, 2005.

MOREIRA, M. M.; CORREA, P. G.. Abertura comercial e indústria: o que se pode esperar e o que se vem obtendo. Revista de Economia Política, v. 17, n. 2, p. 61-91, 1997.

MOREIRA, M. "Estrangeiros em uma Economia Aberta; Impactos Recentes sobre a Produtividade, a Concentração e o Comércio Exterior", in F. Giambiagi \& M. Moreira (org.) A Economia Brasileira nos Anos 90. BNDES, Rio de Janeiro, 1999.

NASSIF, A. Estrutura e competitividade da indústria de bens de capital brasileira. Texto para discussão, n. 109, 2007.

NASSIF, A; FERREIRA, T.T. O setor de bens de capital: diagnóstico e perspectivas. In: ALEM, A. C.; GIAMBIAGI, F. O BNDES em um Brasil em transição. Rio de Janeiro : BNDES, 2010.

NELSON, R.; ROSENBERG, N. Technical innovation and national systems. In: NELSON, R. (Ed.), National Innovation Systems. Oxford University Press, Oxford, 1993.

NELSON, R.; WINTER, S. In search of a useful theory of innovation. Research Policy, v.5. p. 36-78, 1977.

NEUMAN, W.L. Social research methods: qualitative and quantitative approaches. Needhan Heights, MA: Allyn and Bacon, 1994

OCDE. Oslo Manual: guidelines for collecting and interpreting innovation data, 3rd Edition, 2005 .

OYELERAN-OYEYINKA, B. \& RASIIAH, R. (2009) Uneven Paths of Development. Innovation and Learning in Asia and Africa. Edward Elgar, Cheltenham, UK, Northampton, MA, USA.

OREIRO, J.L.; PUNZO,L.; ARAÚJO, E.; SQUEFF,G. Restrições macroeconômicas ao crescimento da economia brasileira: diagnósticos e algumas proposições de política. Texto para discussão n.1431, Ipea, 2009.

ORSENIGO, L. Technological regimes, patterns of innovative activities and industrial dynamics. Cahiers d'economie et sociologie rurales, n.37, p.26-67, 1995.

PAVITT, K. Sectoral patterns of technical change: towards a taxonomy and a teory. Research Policy, v. 13, n. 6, p. 343-373, 1984.

PENEDER, M., Intangible Investment and Human Resources, Journal of Evolutionary Economics 12, 107-134, 2002.

Industry classifications. Aim, scope and techniques. Journal of Industry, Competition and Trade, v.3, n. (1-2), p.109-129, 2003.

PICH, M.T.; LOCH, C.H.; DE MEYER, A. "On uncertainty, ambiguity, and complexity in project management.” Management Science, v.48, n.8, p. 1008-1023, 2002. 
RADOSEVIC, S. 'International technology transfer policy: from 'contract bargaining' to 'sourcing'", in Technovation, Vol. 19, N. 6/7, p. 433-444, 1999.

RAYMOND, W.; MOHNEN, P.; PALM, F.; VAN DER LOEFF, S.S. An Empirically-Based Taxonomy of Dutch Manufacturing: Innovation Policy Implications. University of Maastricht, 2004.

RESENDE, A.V. A indústria de bens de capital de Minas Gerais: oportunidades e entraves ao seu desenvolvimento. Tese (Doutorado) - Universidade Estadual de Campinas - Instituto de Economia, Campinas, 1994.

RESENDE, M. F. C.; ANDERSON, P. Mudanças estruturais na indústria brasileira de bens de capital. Texto para discussão n.658. Brasília: Ipea, 1999.

ROMIJN, H. Acquisition of Technological Capability in Development: A Quantitative Case Study of Pakistan's Capital Goods Sector. World Development, Vol. 25, No. 3, p. 359-311, 1997.

ROSENBERG, N. "Capital goods, technology and economic growth". Oxford: Oxford Economic Papers, Oxford Univ Press 1963.

SABATO, J. A. Ensayos de Campera, Juarez Editor, Buenos Aires, 1979.

SHAH, S.K.; CORLEY, K.G. Building Better Theory by Bridging the QuantitativeQualitative Divide. Journal of Management Studies, V. 43, N. 8, p. 1821-1835, 2006

SAHAL D. "The innovation dynamics and technology cycles in the computer industry". Omega 2, 153-163, 1984

SALERNO, M.; KUBOTA, L. Estado e Inovação. In: Kubota, L.; De Negri, J. (orgs.) Políticas de Incentivo à Inovação Tecnológica no Brasil. IPEA: Brasília, 2008.

SAMPIERI, R. H., COLLADO, C. F., LUCIO, P. B.. Metodologia de pesquisa. São Paulo: McGraw-Hill, 2012.

SARI, J. F. The MPS and the Bill of Material go hand-in-hand. Richard C. Ling Inc., 1981.

SIEBER, S.D. The Integration of Fieldwork and Survey Methods. American Journal of Sociology, Vol. 78, No. 6, p. 1335-1359, 1973

SILVA, E. H., \& HASENCLEVER, L. Regime tecnológico e emergência dos padrões de estratégias inovativas das firmas. Revista Brasileira de Inovação, 13(1 jan/jun), 45-76, 2014.

SBRAGIA, R.; KRUGLIANSKAS, I.; ARANGO-ALZETE, T. Empresas inovadoras no Brasil: uma proposição de tipologia e características associadas. In: IX seminário latinoiberoamericano de gestión tecnológica, inovación tecnológica en la econoía del conocimiento, 9, 2001, Costa Rica, Anais... CD-Rom.

SCHUMPETER, J.A. Teoria do desenvolvimento economico: uma investigacao sobre lucros, capital, credito, juro e o ciclo economico. São Paulo. Abril Cultural, 1982

STEWART, F. Technology and Underdevelopment, MacMillan Press, London, 1977. 
TACLA, C.L.; FIGUEIREDO, P.N. Processos de aprendizagem e acumulação de competências tecnológicas: evidências de uma empresa de bens de capital no Brasil. Revista de Administração Contemporânea, v. 7, n. 3, p.101-126, 2003.

TIDD, J.; BESSANT, J.; PAVITT, K. Gestão da Inovação. Porto Alegre: Bookman, 2008.

Wiley, 2009.

Managing Innovation: integrating technological, market and organizational change.

TIRONI, L. F. Política econômica e desenvolvimento tecnológico: diversificação ou especialização no setor de bens de capital sob encomenda. Dissertação de Mestrado. Universidade de Campinas. Campinas, 1979.

TORRES, S. D. A.; CARVALHO, M. E.; TORRES FILHO, E. T.. Exportações brasileiras de bens de capital: desempenho nos anos recentes. Revista do BNDES, v. 1, n. 1, p. 37-50, 1994.

TSENG, M. M.; PILLER, F. T. The Customer Centric Enterprise: Advances in Mass Customization and Personalization. Springer, 2003.

VALENÇA, A. C. V. A indústria de máquinas e equipamentos para o setor de celulose e papel. BNDES Setorial, n.14, p. 93-110, 2001.

VAN DIJK, M. Technological Regimes and Industrial Dynamics: the Evidence from Dutch Manufacturing, Industrial and Corporate Change, v.9, n. 2, 173-194, 2000.

VARUM, C. A., MONTEIRO, L. V.; Saur-Amaral, I. Dealing with the risks of innovation: A study of capital goods producers in Portugal. Global Business and Organizational Excellence, n.28: p. 34-51, 2009.

Modes of innovation and uncertainties in the capital goods industry. Economics Working Papers, n. 47/2007, 2007.

VERMULM, R. O setor de bens de capital. In: Schwatzman, S. (Org.). Ciência e tecnologia no Brasil: política industrial, mercado de trabalho e instituições de apoio. Editora da Fundação Getúlio Vargas, 1995.

A indústria de bens de capital seriados. Convênio CEPAL/IPEA, 2003.

VERMULM, R.; ERBER, F. Estudo da competitividade de cadeias integradas no Brasil: impactos das zonas de livre comércio. Cadeia: bens de capital. Campinas: Unicamp, IE e MDIC, 2002.

VIOTTI, E. B. Brasil: de política de C\&T para política de inovação. Evolução e desafios das políticas brasileiras de ciência, tecnologia e inovação In: Avaliação de políticas de ciência, tecnologia e inovação: diálogo entre experiências internacionais e brasileiras. Brasília: Centro de Gestão e Estudos Estratégicos, 2008.

VIOTTI, E. B. National learning systems: A new approach on technological change in late industrializing economies and evidences from the cases of Brazil and South Korea. Technological Forecasting and Social Change, v. 69, n.7, p. 653-680, 2002. 
ZHOU, K.Z.; WU, F. Technological capability, strategic flexibility, and product innovation. Strategic Management Journal, v. 3, p. 547-561, 2010. 


\section{Apêndice A - Classificação das empresas segundo o CNAE}

\section{CNAE 2.0 \\ 28 FABRICAÇÃO DE MÁQUINAS E EQUIPAMENTOS}

\subsection{Fabricação de Motores, Bombas, Compressores e Equipamentos de Transmissão}

\subsection{1-9 Fabricação de motores e turbinas, exceto para aviões e veículos rodoviários}

- fabricação de motores estacionários de combustão interna (gasolina e diesel) para tratores e outras máquinas

- fabricação de motores marítimos

- fabricação de motores de combustão interna para locomotivas, carros-motor e automotrizes

- fabricação de caldeiras geradoras de vapor e de máquinas a vapor para embarcações, com ou sem caldeira

- fabricação de caldeiras geradoras de vapor para locomotiva

- fabricação de turbinas a vapor para embarcações

- fabricação de turbinas e rodas hidráulicas

- fabricação de moinhos de vento e outras máquinas eólicas produtoras de energia motriz

- fabricação de máquinas motrizes diversas

- fabricação de peças e acessórios para máquinas motrizes não-elétricas

- instalação, manutenção e reparação de máquinas motrizes não-elétricas quando executadas pelo fabricante

\subsection{2-7 Fabricação de equipamentos hidráulicos e pneumáticos, exceto válvulas}

- fabricação de máquinas e motores hidráulicos com bombas de grande potência

- fabricação de bombas hidráulicas centrífugas, rotativas ou de pistão, de baixa ou alta pressão

- fabricação de cilindros hidráulicos e pneumáticos

- fabricação de peças e acessórios para equipamentos hidráulicos e pneumático

- instalação, manutenção e reparação de equipamentos hidráulicos e pneumáticos, quando executadas pelo fabricante

\subsection{3-5 Fabricação de válvulas, registros e dispositivos semelhantes}

- fabricação de válvulas industriais (automáticas, de pressão, solenoide simples, borboleta, esferas e semelhantes)

- fabricação de válvulas, torneiras e registros sanitários

- fabricação de peças e acessórios para válvulas industriai

- manutenção e reparação de válvulas industriais, quando executadas pelo fabricante

\subsection{4-3 Fabricação de compressores}

- fabricação de compressores de ar estacionários ou portáteis, equipados ou não com motores elétricos

- fabricação de compressores de gás 
- fabricação de compressores frigoríficos

- fabricação de peças e acessórios para compressores

- instalação, manutenção e reparação de compressores, quando executadas pelo fabricante

\subsection{5-1 Fabricação de equipamentos de transmissão para fins industriais}

- fabricação de rolamentos (esféricos, cilíndricos e outros) para fins industriais

- fabricação de mancais, eixos, embreagens, ampliadores e redutores de velocidade, juntas de articulação e similares

\subsection{Fabricação de Máquinas e Equipamentos de Uso Geral}

\subsection{1-6 Fabricação de aparelhos e equipamentos para instalações térmicas}

- fabricação de fornos elétricos para siderurgia, metalurgia e outras aplicações industriais

- fabricação de estufas, secadores, evaporadores, trocadores de calor, fornos não-elétricos e semelhantes

- fabricação de máquinas, aparelhos e equipamentos para instalações térmicas alimentados por energia solar

- fabricação de equipamentos de aquecimento não-elétricos de montagem permanente (p. ex. alimentados por energia solar)

- fabricação de incineradores

- fabricação de aquecedores para piscinas

- fabricação de peças e acessórios para aparelhos e equipamentos para instalações térmicas

- instalação, manutenção e reparação de equipamentos para instalações térmicas, quando executadas pelo fabricante

28.22-4 Fabricação de máquinas, equipamentos e aparelhos para transporte e elevação de cargas e pessoas

- fabricação de elevadores de carga, empilhadeiras, carregadores mecânicos, macacos hidráulicos, pontes rolantes e outros aparelhos para carga, descarga e manipulação de mercadorias

- fabricação de elevadores de passageiros, pontes rolantes, teleféricos, escadas rolantes e outros aparelhos para transporte de pessoas

- fabricação de peças e acessórios para máquinas, aparelhos e equipamentos para transporte e elevação de cargas

- instalação, manutenção e reparação de equipamentos para transporte e elevação de cargas e pessoas, quando executadas pelo fabricante

\subsection{3-2 Fabricação de máquinas $e$ aparelhos de refrigeração e ventilação para uso industrial e comercial}

- fabricação de balcões e câmaras frigoríficas, de uso industrial e comercial, equipados ou não com motores elétricos

- fabricação de armazéns frigoríficos pré-fabricados

- fabricação de aspiradores, exaustores, ventiladores e outros aparelhos de refrigeração e ventilação, equipados ou não com motores elétricos 
- fabricação de peças e acessórios para máquinas e aparelhos de refrigeração e ventilação de uso industrial e comercial

- instalação, manutenção e reparação de máquinas e aparelhos de refrigeração e ventilação de usos industrial e comercial, quando executadas pelo fabricante

\subsection{4-1 Fabricação de aparelhos e equipamentos de ar condicionado}

- fabricação de equipamentos de ar condicionado central

- fabricação de aparelhos de ar condicionado, inclusive para veículos

- fabricação de peças e acessórios para aparelhos e equipamentos de ar condicionado

\subsection{5-9 Fabricação de máquinas e equipamentos para saneamento básico e ambiental}

- produção de equipamentos para controle da poluição ambiental e saneamento básico, tanto para fins industriais como urbanos

- fabricação de equipamentos destinados ao tratamento de água, esgotos sanitários, efluentes industriais, ar, tratamento e disposição de resíduos sólidos, desobstrução de tubulações, distribuição, adução e coleta

\subsection{9-1 Fabricação de máquinas e equipamentos de uso geral não especificados anteriormente}

- fabricação de unidades de retificação e destilação para refinarias de petróleo, indústrias químicas e de bebidas, etc.

- fabricação de balanças industriais, comerciais e domésticas, automáticas e não

- fabricação de plataformas para pesagem de caminhões

- fabricação de extintores de incêndio

- fabricação de máquinas de embalar, ensacar e etiquetar

- fabricação de máquinas de filtrar e depurar líquidos

- fabricação de calandras

- fabricação de intercambiadores (trocadores) de calor

- fabricação de vaporizadores, exceto agrícolas

- fabricação de máquinas automáticas para venda de produtos

- fabricação de calculadoras eletrônicas ou não

- fabricação de mimeógrafos, duplicadores, perfuradores

- fabricação de máquinas de escrever, calcular e outras máquinas para escritório.

- fabricação de equipamentos para escritório como apontadores, grampeadores, extratores de grampos, etc.

- fabricação de câmaras de bronzeamento

- fabricação de carrosséis, balanços, galerias de tiro e outros equipamentos para feiras e parques de diversões

- fabricação de outras máquinas e equipamentos de uso geral

- fabricação de peças e acessórios para máquinas e equipamentos de uso geral

- instalação, manutenção e reparação de máquinas e equipamentos de uso geral, quando executadas pelo fabricante 


\subsection{Fabricação de Máquinas-Ferramenta}

\subsection{0-2 Fabricação de máquinas-ferramenta}

- fabricação de máquinas-ferramenta para trabalhar metais

- fabricação de máquinas-ferramenta para trabalhar madeira, pedra, borracha endurecida, plástico endurecido, vidro a frio, etc.

- fabricação de máquinas-ferramenta para estampar, tornear, fresar, retificar, prensar (prensas hidráulicas), cortar, forjar, etc.

- fabricação de máquinas-ferramenta de comando numérico ou que integrem várias fases do trabalho

- fabricação de máquinas-ferramenta para trabalhar mediante raio laser

- fabricação de máquinas de solda que utilizem raio laser, impulsos magnéticos, etc.

- fabricação de ferramentas manuais elétricas (furadeiras, lixadeiras, politrizes, serras, etc.) e de funcionamento com ar comprimido

- fabricação de máquinas-ferramenta não-elétricas

- fabricação de peças e acessórios para máquinas-ferramenta (mandris, porta-ferramentas

- instalação, manutenção e reparação de máquinas-ferramenta, quando executadas pelo fabricante

\subsection{Fabricações de Máquinas e Equipamentos de Uso Industrial Específico}

28.61-5 Fabricação de máquinas para a indústria metalúrgica, exceto máquinasferramenta

- fabricação de máquinas e equipamentos para a indústria siderúrgica e metalúrgica (convertedores, laminadores, trens de laminação, etc.)

- fabricação de lingoteiras para siderurgia

- fabricação de cadinhos e colheres para fundição

- fabricação de peças e acessórios para máquinas e equipamentos para a indústria siderúrgica e metalúrgica

- instalação, manutenção e reparação de máquinas e equipamentos para a indústria siderúrgica e metalúrgica, quando executadas pelo fabricante

28.62-3 Fabricação de máquinas e equipamentos para as indústrias de alimentos, bebidas $e$ fumo

- fabricação de máquinas e equipamentos para frigoríficos, matadouros e abatedouros

- fabricação de máquinas e aparelhos para a indústria do laticínio (desnatadeiras, pasteurizadores, batedores de manteiga, etc.)

- fabricação de equipamentos, inclusive de calefação elétrica, para tratamento de alimentos e bebidas, mediante troca de temperatura (pasteurização, condensação, etc.)

- fabricação de máquinas e aparelhos para as indústrias de conservas de frutas e legumes (descascadeiras, cozinhadores, etc.)

- fabricação de máquinas e aparelhos para panificação, massas alimentícias, biscoitos, balas e bombons (masseiras, cortadeiras, cilindros, fornos para padarias, etc.) 
- fabricação de máquinas, aparelhos e instalações para a indústria de óleos (prensas, filtros)

- fabricação de máquinas e aparelhos para a indústria do fumo (picadores, máquinas para cigarros, etc.)

- fabricação de máquinas para a indústria do açúcar (moendas, cozinhadores, etc.)

- fabricação de máquinas e aparelhos para a indústria de bebidas (dosadores, misturadores)

- fabricação de máquinas para beneficiamento e preparação de produtos agrícolas utilizadas na indústria da moagem

- fabricação de máquinas para a preparação de alimentos em hotéis e restaurantes

- fabricação de peças e acessórios para máquinas e equipamentos para as indústrias alimentar, de bebida e fumo

- instalação, manutenção e reparação de máquinas e equipamentos para as indústrias alimentar, de bebida e fumo, quando executadas pelo fabricante

\subsection{3-1 Fabricação de máquinas e equipamentos para a indústria têxtil}

- fabricação de máquinas e equipamentos para a indústria têxtil (abridores, cardas, maçaroqueiras, urdideiras, filatórios, teares, instalações para tinturaria e estamparia de tecidos, etc.)

- fabricação de equipamentos auxiliares para máquinas têxteis (bastidores, liços, mecanismo jacquard, etc.)

- fabricação de peças e acessórios para máquinas e equipamentos para a indústria têxtil

- fabricação de carretéis e bobinas de madeira (componentes para máquinas têxteis)

- instalação, manutenção e reparação de máquinas e equipamentos para a indústria têxtil, quando executadas pelo fabricante

\subsection{4-0 Fabricação de máquinas e equipamentos para as indústrias do vestuário, do couro e de calçados}

- fabricação de máquinas de costura de uso industrial

- fabricação de máquinas e aparelhos para as indústrias do vestuário e confecção de tecidos (para cortar, casear, pregar botões, bordar, etc.)

- fabricação de máquinas e aparelhos para as indústrias do couro, curtumes, correaria, selaria, etc. (alisadores para couros, prensas, etc.)

- fabricação de máquinas e aparelhos para a indústria do calçado (pespontadeiras, máquinas para montar calçados, etc.)

- fabricação de máquinas para reparação de calçados

- fabricação de máquinas de tricotar

- fabricação de máquinas de costura de uso doméstico

- fabricação de máquinas, aparelhos e equipamentos para lavanderias, tinturarias e semelhantes (lavadoras e secadoras comerciais, máquinas de limpeza à seco, etc

- fabricação de cabeçotes para máquinas de costura

- fabricação de agulhas para máquinas de costura

- fabricação de peças e acessórios para máquinas e equipamentos para as indústrias do vestuário e de couro e calçados 
- instalação, manutenção e reparação de máquinas e equipamentos para as indústrias do vestuário e de couro e calçados, quando executadas pelo fabricante

28.65-8 Fabricação de máquinas e equipamentos para as indústrias de celulose, papel e papelão e artefatos

- fabricação de máquinas e aparelhos para a indústria da celulose, papel, papel-cartão e papelão (despolpadeiras, cozinhadores, clarificadores, etc.)

- fabricação de máquinas e equipamentos para a indústria de artefatos de papel e cartonagem (tesourões, guilhotinas, etc.)

- fabricação de peças e acessórios para máquinas e equipamentos para as indústrias de celulose, papel e papelão

- instalação, manutenção e reparação de máquinas e equipamentos para as indústrias de celulose, papel e papelão e artefatos, quando executadas pelo fabricante

\subsection{6-6 Fabricação de máquinas e equipamentos para a indústria do plástico}

- fabricação de máquinas e aparelhos para a indústria de artigos de plástico (máquinas para extrudar, soldar, prensar, injetar e semelhantes)

- fabricação de peças e acessórios para máquinas e equipamentos para a indústria do plástico

- instalação, manutenção e reparação de máquinas e equipamentos para a indústria do plástico, quando executadas pelo fabricante

28.69-1 Fabricação de máquinas e equipamentos para uso industrial específico não especificados anteriormente

- fabricação de máquinas e equipamentos para a indústria da madeira: serrarias, carpintarias, marcenarias, etc.

- fabricação de máquinas e equipamentos para a indústria de perfumaria, sabões e velas (cozinhadores, cilindros, etc.)

- fabricação de máquinas e aparelhos para a indústria de cerâmica, artefatos de cimento e olarias (marombas, prensas, modeladores, etc.)

- fabricação de máquinas e aparelhos para a indústria da borracha

- fabricação de máquinas e aparelhos para a indústria gráfica (máquinas impressoras, máquinas para litografia, etc.)

- fabricação de máquinas para trabalhar fibra de vidro e filamentos contínuos artificiais

- fabricação de robôs industriais para usos diversos

- fabricação de máquinas para encadernação

- fabricação de máquinas para trabalhar vidro a quente

- fabricação de máquinas para a indústria do refino do petróleo

- fabricação de outras máquinas e equipamentos de uso industrial específico

- fabricação de peças e acessórios para máquinas e equipamentos de uso industrial específico

- instalação, manutenção e reparação de máquinas e equipamentos de uso industrial específico, quando executadas pelo fabricante. 


\section{Apêndice B - Roteiro de entrevistas}

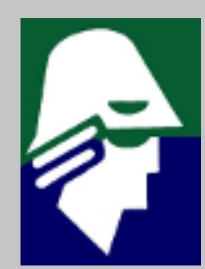

Universidade de São Paulo

Escola de Engenharia de São Carlos

\section{Departamento de Engenharia de Produção}

\section{PROPÓSITO DA PESQUISA}

Este roteiro tem por objetivo explorar os fatores que intervém no processo de mudança tecnológica, visando à identificação de suas principais barreiras e necessidades para a promoção da inovação. Os resultados visam servir de apoio para a formulação de políticas públicas de promoção dessas empresas. A pesquisa faz parte de uma tese de doutorado pela EESC/USP.

\section{OBRIGATORIEDADE E SIGILO DAS INFORMAÇÕES}

A presente pesquisa mantém o caráter obrigatório e confidencial atribuído às informações coletadas pelo pesquisador as quais se destinam, exclusivamente, a fins acadêmicos.

\section{IDENTIFICAÇÃO DA EMPRESA}

1- Razão Social:

2- Porte: ( ) Micro （ ) Pequena （ ) Média （ ） Grande Ano de Fundação:

3- Segmento da atividade principal:

4- Número atual de funcionários:

\section{5- Código CNAE}

6- Vínculo: ( ) empresa independente ( ) faz parte de um grupo

7- Capital controlador da empresa: ( ) Nacional （ ) Estrangeiro （ ) Nacional e Estrangeiro

8- Principais produtos: valor agregado: colocar em ordem de crescente de valor $\left(1^{\circ} ; 2^{\circ}\right.$ e $\left.3^{\circ}\right)$

Produto 1: Participação RLV $\%$ Valor agregado

Produto 2: Participação RLV $\%$ Valor agregado

Produto 3: Participação RLV $\%$ Valor agregado

\section{MERCADO/CLIENTES}

1. Participação do total de vendas no mercado:

Mercado interno: \% da produção e participação da receita líquida de vendas (RLV) $\%$

Mercado externo: \% da produção e participação da receita líquida de vendas (RLV) $\%$

Principais mercados de exportação (países e produto):

Por que não exporta?

2. Evolução do Market share (em \% e em relação ao ano anterior) por linha de produto nos últimos cinco anos.
Produto 1: ( ) diminuiu
( ) manteve
( ) cresceu
( ) oscilou
Produto 2: ( ) diminuiu
( ) manteve
( ) cresceu
( ) oscilou
Produto 3: ( ) diminuiu
( ) manteve
( ) cresceu
( ) oscilou

3. Clientes: Principais setores atendidos e grau de exigência tecnológica

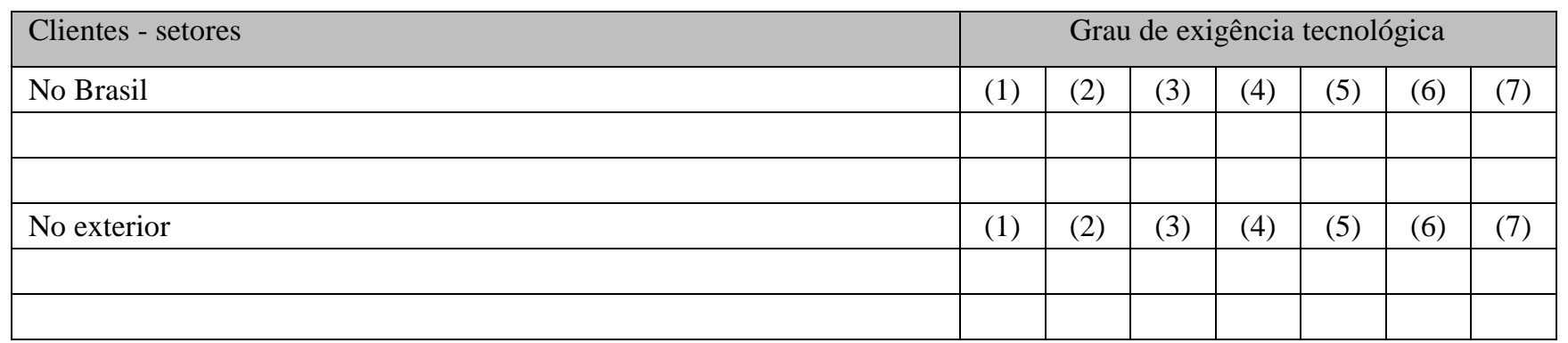


4. Para atender às necessidades de seus mercados de atuação é necessário o uso de qual tipo de tecnologia?
Mercado nacional:
( ) tecnologia existente
( ) tecnologia apropriada (adaptada)
Mercado externo:
( ) tecnologia existente
( ) tecnologia apropriada (adaptada)

5. Qual é a influência da China e de outros países emergentes (o quanto afetam) na competitividade de sua empresa? 1-7

6. Defesa comercial: qual é o nível de conhecimento sobre o produto, concorrentes e monitoramento do mercado?

\begin{tabular}{|l|c|c|c|c|c|c|c|}
\hline Fatores & \multicolumn{5}{|c|}{ Intensidade } \\
\hline $\begin{array}{l}\text { Conhecimento do grau de satisfação de seu produto } \\
\text { (aspectos técnicos e comerciais). }\end{array}$ & $(1)$ & $(2)$ & $(3)$ & $(4)$ & $(5)$ & $(6)$ & $(7)$ \\
\hline $\begin{array}{l}\text { Conhecimento dos principais concorrentes (países, } \\
\text { fabricantes e revendedores). }\end{array}$ & $(1)$ & $(2)$ & $(3)$ & $(4)$ & $(5)$ & $(6)$ & $(7)$ \\
\hline Monitoramento constante de seu mercado Nacional. & $(1)$ & $(2)$ & $(3)$ & $(4)$ & $(5)$ & $(6)$ & $(7)$ \\
\hline Monitoramento constante de seu mercado Internacional & $(1)$ & $(2)$ & $(3)$ & $(4)$ & $(5)$ & $(6)$ & $(7)$ \\
\hline
\end{tabular}

7. Comparar os principais produtos de sua empresa com os da concorrência nacional e internacional. (Relacionar para cada fator a intensidade competitiva em uma escala de 1 (um) a 7 (sete).

\begin{tabular}{|l|l|l|l|l|}
\hline Principais produtos da empresa & \multicolumn{1}{|c|}{ Mercados } & Preço & Diferenciação & Conteúdo tecnológico \\
\hline \multirow{5}{*}{} & Sua Empresa & & & \\
\cline { 2 - 5 } & Concorrente nacional & & & \\
\hline & Concorrente no exterior & & & \\
\hline & Empresa & & & \\
\hline
\end{tabular}

\section{OBJETIVOS DA INOVAÇÃO (qualificação da inovação)}

1. A inovação de seu produto visa
( ) substituir um produto importado
( ) oferecer um produto diferente do mercado existente

2. Em relação ao mercado e ao produto, os projetos de inovação visam:

\section{Mercado}

( ) Manter o mercado atual

( ) Ampliar o mercado atual

( ) Abrir novo mercado

Produto
( ) Substituição de produtos obsoletos
( ) Ampliar linhas de produtos atuais
( ) Abrir novas linhas de produtos
( ) Manter atual linha de produtos com melhoria da qualidade

3. Crescimento da sua empresa depende: Colocar em ordem de importância: $1^{\circ}$ e $2^{\circ}$.

( ) do crescimento ou comportamento da demanda: fortalecimento dos clientes frente à concorrência

( ) de maior capacidade de oferecer produtos mais competitivos tecnologicamente 


\section{CAPACITAÇÃO}

1. A empresa tem realizado programas de capacitação tecnológica nos últimos 5 anos? ( ) SIM （ ) NÃO

2. Investimentos nas áreas tecnológicas e administrativas.

\begin{tabular}{|l|l|l|l|}
\hline ÁREAS & Insuficiente & Parcialmente suficiente & Suficiente \\
\hline Tecnológicas & & & \\
\hline Administrativas & & & \\
\hline
\end{tabular}

3. Estrutura do setor de Engenharia de Processo

\begin{tabular}{|l|l|l|l|l|l|l|l|l|l|}
\hline Engenharia de processos & Atual & Nec. & \multicolumn{7}{|c|}{ Grau de qualificação } \\
\hline Engenharia de Fabricação & & & $(1)$ & $(2)$ & $(3)$ & $(4)$ & $(5)$ & $(6)$ & $(7)$ \\
\hline PCP & & & $(1)$ & $(2)$ & $(3)$ & $(4)$ & $(5)$ & $(6)$ & $(7)$ \\
\hline Qualidade & & & $(1)$ & $(2)$ & $(3)$ & $(4)$ & $(5)$ & $(6)$ & $(7)$ \\
\hline Manutenção & & & $(1)$ & $(2)$ & $(3)$ & $(4)$ & $(5)$ & $(6)$ & $(7)$ \\
\hline
\end{tabular}

\section{ESFORÇOS TECNOLÓGICOS PARA INOVAÇÃO}

1. Nos último 5 anos qual tem sido a intensidade dos investimentos em pesquisa e desenvolvimento de produtos?
Dispêndios em \% do faturamento bruto:
( ) diminuiu
( ) manteve
( ) cresceu
( ) oscilou

4. Nos últimos 5 anos qual tem sido o direcionamento das atividades de inovação? Quais os resultados obtidos?

\begin{tabular}{|l|l|l|l|l|l|}
\hline Direcionamento das atividades de inovação (domínio tecnológico) & $\mathbf{2 0 0 9}$ & $\mathbf{2 0 1 0}$ & $\mathbf{2 0 1 1}$ & $\mathbf{2 0 1 2}$ & $\mathbf{2 0 1 3}$ \\
\hline $\begin{array}{l}\text { Realização de melhorias para adaptar às próprias necessidades, } \\
\text { Inovação de caráter pontual, adaptativo e incremental. }\end{array}$ & & & & & \\
\hline Realização de Pesquisa e Desenvolvimento de novos produtos (P\&D) & & & & & \\
\hline
\end{tabular}

5. Patentes: A empresa, nos últimos 5 anos, depositou alguma patente?
1. ( ) NÃO
2. ( ) SIM
( ) Na matriz
( ) No Brasil:
( ) No exterior:

6. Fatores de maior dificuldade ou barreiras para o desenvolvimento da empresa. Comentar as respostas

\begin{tabular}{|l|c|c|c|c|c|c|c|}
\hline Fatores/obstáculos ao desenvolvimento & \multicolumn{7}{|c|}{ Níveis de dificuldade/barreira } \\
\hline Pesquisa e Desenvolvimento de produtos (P\&D) & $(1)$ & $(2)$ & $(3)$ & $(4)$ & $(5)$ & $(6)$ & $(7)$ \\
\hline Escala de produção & $(1)$ & $(2)$ & $(3)$ & $(4)$ & $(5)$ & $(6)$ & $(7)$ \\
\hline Qualificação de mão-de-obra & $(1)$ & $(2)$ & $(3)$ & $(4)$ & $(5)$ & $(6)$ & $(7)$ \\
\hline Produção com qualidade & $(1)$ & $(2)$ & $(3)$ & $(4)$ & $(5)$ & $(6)$ & $(7)$ \\
\hline Obtenção de financiamentos para projetos & $(1)$ & $(2)$ & $(3)$ & $(4)$ & $(5)$ & $(6)$ & $(7)$ \\
\hline Capital de giro & $(1)$ & $(2)$ & $(3)$ & $(4)$ & $(5)$ & $(6)$ & $(7)$ \\
\hline Níveis desejáveis de produtividade & $(1)$ & $(2)$ & $(3)$ & $(4)$ & $(5)$ & $(6)$ & $(7)$ \\
\hline Custos logísticos: transporte e distribuição & $(1)$ & $(2)$ & $(3)$ & $(4)$ & $(5)$ & $(6)$ & $(7)$ \\
\hline Concorrentes estrangeiros & $(1)$ & $(2)$ & $(3)$ & $(4)$ & $(5)$ & $(6)$ & $(7)$ \\
\hline Concorrentes nacionais & $(1)$ & $(2)$ & $(3)$ & $(4)$ & $(5)$ & $(6)$ & $(7)$ \\
\hline Taxa de juros & $(1)$ & $(2)$ & $(3)$ & $(4)$ & $(5)$ & $(6)$ & $(7)$ \\
\hline Política cambial & $(1)$ & $(2)$ & $(3)$ & $(4)$ & $(5)$ & $(6)$ & $(7)$ \\
\hline Política comercial & $(1)$ & $(2)$ & $(3)$ & $(4)$ & $(5)$ & $(6)$ & $(7)$ \\
\hline Impostos e encargos & $(1)$ & $(2)$ & $(3)$ & $(4)$ & $(5)$ & $(6)$ & $(7)$ \\
\hline
\end{tabular}


7. Quais as principais dificuldades ou obstáculos para competir no mercado interno? Qual é o grau de dificuldade (de 1 a 7)

8. Quais as principais dificuldades ou obstáculos para competir no mercado externo? Qual é o grau de dificuldade (de 1 a 7 )

9. Obstáculos para criação de novas tecnologias

\begin{tabular}{|l|c|c|c|c|c|c|c|}
\hline Obstáculos para criação de novas tecnologias & \multicolumn{7}{|c|}{ Níveis } \\
\hline Desenvolvimento de um a estrutura de P\&D & $(1)$ & $(2)$ & $(3)$ & $(4)$ & $(5)$ & $(6)$ & $(7)$ \\
\hline Máquinas e equipamentos & $(1)$ & $(2)$ & $(3)$ & $(4)$ & $(5)$ & $(6)$ & $(7)$ \\
\hline Acesso a fontes de informação externa sobre tecnologia & $(1)$ & $(2)$ & $(3)$ & $(4)$ & $(5)$ & $(6)$ & $(7)$ \\
\hline Acesso a recursos financeiros não reembolsáveis & $(1)$ & $(2)$ & $(3)$ & $(4)$ & $(5)$ & $(6)$ & $(7)$ \\
\hline Disponibilidade de políticas públicas & $(1)$ & $(2)$ & $(3)$ & $(4)$ & $(5)$ & $(6)$ & $(7)$ \\
\hline Acesso a programas governamentais (editais, etc) & $(1)$ & $(2)$ & $(3)$ & $(4)$ & $(5)$ & $(6)$ & $(7)$ \\
\hline Estrutura organizacional (ambiente para inovação) & $(1)$ & $(2)$ & $(3)$ & $(4)$ & $(5)$ & $(6)$ & $(7)$ \\
\hline Cooperação com outras empresas & $(1)$ & $(2)$ & $(3)$ & $(4)$ & $(5)$ & $(6)$ & $(7)$ \\
\hline Custos de inovação & $(1)$ & $(2)$ & $(3)$ & $(4)$ & $(5)$ & $(6)$ & $(7)$ \\
\hline Recursos humanos para inovação & $(1)$ & $(2)$ & $(3)$ & $(4)$ & $(5)$ & $(6)$ & $(7)$ \\
\hline Centralização das atividades para inovação em outra empresa & $(1)$ & $(2)$ & $(3)$ & $(4)$ & $(5)$ & $(6)$ & $(7)$ \\
\hline Informações sobre mercado & $(1)$ & $(2)$ & $(3)$ & $(4)$ & $(5)$ & $(6)$ & $(7)$ \\
\hline
\end{tabular}

\section{INOVAÇÃO EM PRODUTO E PROCESSO}

1. Existe setor de P\&D estruturado na empresa? （ ） SIM （ ） NÃO

2. Sua empresa segue os concorrentes no lançamento de novos produtos?
( ) NÃO
( ) SIM
Após quanto tempo seu produto é lançado? anos

3. Entre 2008 e 2013 a empresa introduziu novo produto? Qual o grau de novidade atribuído ao novo produto/processo?

\begin{tabular}{|c|c|c|c|c|c|c|c|c|c|c|c|c|}
\hline \multirow{3}{*}{$\begin{array}{l}\text { Grau de novidade do principal produto (PD) / } \\
\text { processo (PC) (forma pela qual os produtos são } \\
\text { criados ou oferecidos) }\end{array}$} & \multicolumn{12}{|c|}{ Períodos } \\
\hline & \multicolumn{2}{|c|}{2008} & \multicolumn{2}{|c|}{2009} & \multicolumn{2}{|c|}{2010} & \multicolumn{2}{|c|}{2011} & \multicolumn{2}{|c|}{2012} & \multicolumn{2}{|c|}{2013} \\
\hline & PD & $\mathrm{PC}$ & PD & $\mathrm{PC}$ & PD & $\mathrm{PC}$ & PD & $\mathrm{PC}$ & PD & $\mathrm{PC}$ & PD & $\mathrm{PC}$ \\
\hline \multicolumn{13}{|l|}{ Aprimoramento de um existente. } \\
\hline \multicolumn{13}{|l|}{$\begin{array}{l}\text { Novo para a empresa, mas já existente no mercado } \\
\text { nacional. }\end{array}$} \\
\hline \multicolumn{13}{|l|}{$\begin{array}{l}\text { Novo para o mercado nacional, mas já existente } \\
\text { no mercado mundial. }\end{array}$} \\
\hline \multicolumn{13}{|l|}{ Novo para o mercado mundial. } \\
\hline $\begin{array}{l}\text { Produtos inventados, mas não lançados ou sem } \\
\text { aceitação no mercado. }\end{array}$ & & & & & & & & & & & & \\
\hline
\end{tabular}


4. Equipamentos: aquisição grau de atualização internacional

\begin{tabular}{|l|l|l|l|l|l|l|l|l|l|}
\hline Principais equipamentos/ano aquisição & \multicolumn{6}{|c|}{ Grau de atualização internacional } & $\begin{array}{c}\text { Necessidade de } \\
\text { Substituição } \\
\text { do equipamento } \\
\text { SIM - NÃO }\end{array}$ \\
\hline & $(1)$ & $(2)$ & $(3)$ & $(4)$ & $(5)$ & $(6)$ & $(7)$ & $($ ) SIM ( ) NÃO \\
\hline & $(1)$ & $(2)$ & $(3)$ & $(4)$ & $(5)$ & $(6)$ & $(7)$ & $($ ) SIM ( ) NÃO \\
\hline & $(1)$ & $(2)$ & $(3)$ & $(4)$ & $(5)$ & $(6)$ & $(7)$ & $($ ) SIM ( ) NÃO \\
\hline
\end{tabular}

5. Engenharia simultânea: Qual é o Grau de integração da engenharia de processos com a engenharia de desenvolvimento de produto? 1 a 7. Grau de integração:

6. Quais setores ou áreas da produção que mais precisam de atualização ou investimentos? (qualidade, projetos, PCP, etc)

7. Quais são os resultados pretendidos com a aquisição de novos equipamentos?
( ) não se aplica
( ) simples substituição por tempo de uso
( ) aumento de escala produtiva
( ) diferenciação de produto (desenvolvimento de novos produtos)
( ) redução de custo operacional

\section{QUALIDADE}

Quais das atividades abaixo sua empresa desenvolve no setor da qualidade? Comentar as respostas.

\begin{tabular}{|c|c|c|c|c|c|c|c|}
\hline Atividades & \multicolumn{7}{|c|}{ Desempenho } \\
\hline ( ) Controle Estatístico de Processo & (1) & (2) & (3) & (4) & (5) & (6) & (7) \\
\hline ) Programas de treinamento & (1) & (2) & (3) & (4) & $(5)$ & (6) & (7) \\
\hline ( ) Auditoria interna da qualidade & (1) & (2) & (3) & (4) & (5) & (6) & (7) \\
\hline ( ) Gestão da Qualidade Total & (1) & (2) & (3) & (4) & (5) & (6) & (7) \\
\hline Possui certificação? Qual? & & & & & & & \\
\hline
\end{tabular}

\section{POLÍTICAS PÚBLICAS}

1. Sua empresa já foi contemplada com algum programa de fomento à inovação tecnológica? Quais os benefícios gerados?

2. As políticas públicas de apoio à inovação, tais os editais e linhas de financiamento, atendem às necessidades de sua empresa? Quais as principais dificuldades para o acesso?

\section{TRANSFERÊNCIA DE TECNOLOGIA}

\begin{tabular}{|l|l|l|l|l|l|l|l|}
\hline Fatores & \multicolumn{4}{|c|}{ Intensidade } \\
\hline Capacidade de P\&D da empresa de gerar tecnologia para mercado nacional & $(1)$ & $(2)$ & $(3)$ & $(4)$ & $(5)$ & $(6)$ & $(7)$ \\
\hline Capacidade de P\&D de gerar a tecnologia para mercado internacional & $(1)$ & $(2)$ & $(3)$ & $(4)$ & $(5)$ & $(6)$ & $(7)$ \\
\hline Custo de importação da tecnologia & $(1)$ & $(2)$ & $(3)$ & $(4)$ & $(5)$ & $(6)$ & $(7)$ \\
\hline Custo de produção própria da tecnologia & $(1)$ & $(2)$ & $(3)$ & $(4)$ & $(5)$ & $(6)$ & $(7)$ \\
\hline Capacidade de adequação da tecnologia & $(1)$ & $(2)$ & $(3)$ & $(4)$ & $(5)$ & $(6)$ & $(7)$ \\
\hline
\end{tabular}


COMPETITIVIDADE DA PRODUÇÃO: Componentes da competitividade da produção. Comentar as respostas

\section{Itens}

Importância $\quad$ Desempenho

Flexibilidade do produto (habilidade de lidar com produtos fora do padrão (customização))

Flexibilidade do processo (A capacidade de produzir pequenas quantidades rentáveis (eficiencia em custo).

Flexibilidade de volume (habilidade de ajustar a capacidade produtiva à flutuações da demanda)

Baixo custo de produção (habilidade em minimizar o custo total de produção através da eficiência operacional)

Introdução de novos produtos (habilidade em introduzir melhorias ou novos produtos)

Confiabilidade do produto (a capacidade para aumentar o tempo de falha ou avaria do produto)

Velocidade de entrega (tempo entre pedido do cliente e entrega)

Qualidade do produto (conformidade às especificações)

Confiabilidade de entrega (entregar no tempo prometido)

Qualidade e inovação no design/projeto (habilidade em fornecer produto com características

operacionais superiores aos dos concorrentes)

\section{FINANCIAMENTO PARA A INOVAÇÃO}

Qual é a origem das fontes de financiamento para a realização das atividades inovativas: avaliar nível de dificuldade: 1 a 7.

Nível:

\section{GESTÃO DA INOVAÇÃ̃O}

Padrão de comportamento da empresa em relação às questões da inovação: 1: não ocorre e 7: ocorre plenamente na empresa

\section{Estratégias}

Atribuição

As pessoas têm uma ideia clara de como a inovação pode ajudar a empresa a competir

A empresa definiu claramente qual é seu diferencial competitivo diante do mercado

Uso de ferramentas e técnicas de prospecção para "tentar prever" ameaças e oportunidades do mercado

Principais executivos têm uma visão compartilhada de como a empresa se desenvolverá através da inovação

Existe uma ligação clara entre os projetos de inovação que a empresa realiza e a estratégia geral do negócio

\section{Processos}

Possui processos organizados e apropriados para a gestão do DP, desde a ideia até o lançamento.

Possui mecanismos eficazes para garantir que todos os funcionários entendam as necessidades do cliente

Possui mecanismos adequados para assegurar o envolvimento prévio de todos os departamentos no DNPP

Os projetos de inovação são normalmente concluídos no prazo e dentro do orçamento

Existe flexibilidade suficiente no sistema de DP para permitir que pequenos projetos "rápidos" aconteçam.

Organização

As pessoas trabalham bem em conjunto além dos limites departamentais da empresa

A comunicação e as atividades "top-down", "bottom-up" e através da organização é eficaz

A empresa trabalha bem em equipe

As pessoas estão envolvidas com sugestão de ideias para a melhorias dos produtos ou processos

A estrutura da empresa é adequada para tomar decisões rapidamente

\section{Interação e ações conjuntas com outros agentes}

Com universidades e outros centros de pesquisa para ajudar no desenvolvimento de seu conhecimento

A empresa é boa em compreender as necessidades de seus clientes/usuários

A empresa tem ações conjuntas com outras empresas para desenvolver novos produtos e processos

A empresa trabalha com seus clientes na exploração e no desenvolvimento de novos conceitos

Desenvolve redes de contato externas que podem ajudá-la, p.e, pessoas com conhecimento especializado. 
CONVERSÃO DE CONHECIMENTO: aquisição, socialização e codificação de conhecimentos. Comentar as respostas






\section{Apêndice C - Carta de apresentação às empresas}

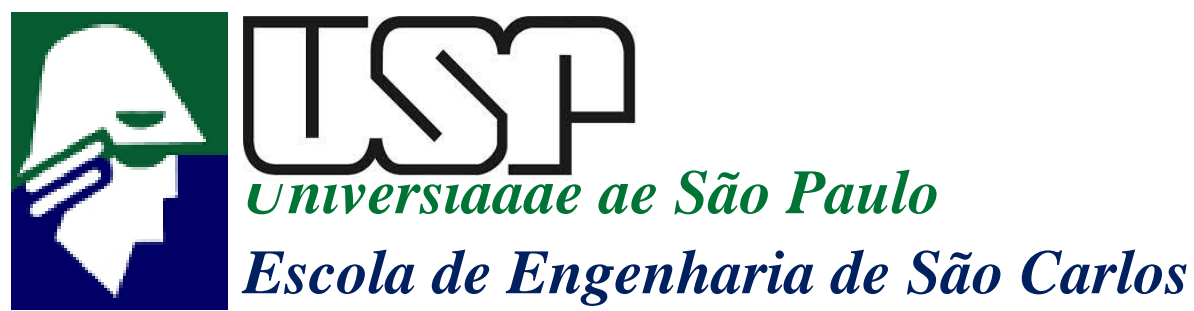

Prezado Sr. (a),

estamos realizando, pela Universidade de São Paulo, uma pesquisa de doutorado sobre capacidade de inovação junto a empresas do setor de bens de capital do Brasil. Este estudo tem por objetivo explorar os fatores que intervém no processo de mudança tecnológica, visando à identificação de suas principais barreiras, e necessidades para a promoção da inovação. Os resultados desse trabalho visam servir de apoio para a formulação de políticas públicas de promoção dessas empresas.

Embora a literatura aborde vários estudos sobre o tema, pouca exploração se tem sobre os fatores que intervém no processo de mudança tecnológica em empresas brasileiras desse setor.

Sendo assim, vimos por meio desta solicitar gentilmente vossa valiosa colaboração nesta fase de trabalho de campo para responder, em entrevista presencial, a algumas questões que demandará cerca de 1 hora de sua atenção.

É importante ressaltar que é uma pesquisa com propósito puramente acadêmico, sendo que na tese, os dados serão tratados de forma agregada, não havendo a divulgação personalizada ou individualizada, mantendo assim o anonimato dos participantes com total confidencialidade.

Assume-se aqui o compromisso de enviar os resultados obtidos ao final dessa pesquisa.

Desde já agradecemos por sua atenção.

Cordialmente,

Prof. Dr. Marcelo Seido Nagano

Professor da Escola de Engenharia de São Carlos - USP

Departamento de Engenharia de Produção

Antonio Iacono

Doutorando da Escola de Engenharia de São Carlos - USP

Departamento de Engenharia de Produção 